\title{
A modinha e o lundu: dois clássicos nos trópicos
}

Tese apresentada ao Programa de PósGraduação em Música, Área de Concentração Musicologia, Linha de Pesquisa: História, Estilo e Recepção, da Escola de Comunicações e Artes da Universidade de São Paulo, como exigência parcial para a obtenção do Título de Doutor em Musicologia, sob a orientação do Prof. Dr. Régis Duprat.

\section{São Paulo \\ 2010}


EDILSON VICENTE DE LIMA

\section{A modinha e o lundu: dois clássicos nos trópicos}

Comissão julgadora

São Paulo , de de 2010 
Dedico este trabalho:

Aos meus pais: Cícero Vicente de Lima e Quitéria Moreira de Lima.

A todos os meus queridos familiares e amigos.

Ao meu querido amigo de juventude, Antonio José da Silva.

Aos meus amigos de universidade: Paulo Augusto Soares, Celso Cintra e Milton Castelli.

À Universidade Cruzeiro do Sul que sempre me acolheu e às amizades que lá desenvolvi.

Serei eternamente grato à:

Todos os meus professores: que ousaram contribuir para minha formação;

Regis Duprat: aquele a quem nunca encontrarei palavras suficientes para expressar meu reconhecimento;

Rosemeire Moreira: a voz que Rousseau não teve oportunidade de ouvir. 


\section{RESUMO}

A tese por nós defendida no texto que se segue tem como objetivo o estudo de dois importantes gêneros musicais, a modinha e o lundu, cujos processos de elaboração iniciam-se a partir da segunda metade do século XVIII no seio da sociedade luso-brasileira. Com o intuito de possibilitar uma reflexão mais abrangente do assunto, muito caro à historiografia musical em língua lusófona, são levados em consideração aqui, aspectos históricos, estilísticos e identitários. A fim de abordarmos de modo adequado a complexidade de nosso objeto de estudo, calcamos nossa metodologia, sobretudo, no estudo da história, articulado à musicologia histórica, à musicologia sistemática e à etnomusicologia. Partindo do reconhecimento de que os gêneros em questão, objeto de nosso estudo, estão ligados às transformações ocorridas no mundo luso-brasileiro e na transformação das concepções estéticas internacionais, procuramos identificá-los com o que acabou por denominar-se estética do sentimento ou sentimentalismo e com o estilo clássico que se desenvolveu na Europa durante o século XVIII, tanto na poesia quanto na música, e que paulatinamente forjaram outras formas de produção e recepção, identificadas com um novo modo de sociabilidade burguesa que dominará o século das luzes. Por outro lado, buscamos, igualmente compreender em que aspecto a cultura popular participou, contribuindo de modo significativo, para a formação desses gêneros $e$, por conseqüência como se dá este impacto na expressividade musical, manifesta já no período de sua formação. A partir do estudo da historiografia, buscamos estabelecer como a modinha e o lundu participam das discussões sobre uma pretensa identidade nacional, ainda calcada em pressupostos positivistas e nacionalistas do século XIX, pressupostos estes que se mantém em parte significativa na literatura do século XX. Finalmente, ao discutirmos sobre a performance, utilizando como fontes registros musicais a partir da década de 1950, procuramos identificar correntes estéticas e ideológicas presentes nesses registros, os quais denominamos paradigmas interpretativos.

\section{Palavras chaves: modinha e lundu, história da música brasileira, estética e iluminismo/ilustração, música e ideologia, performance musical.}




\begin{abstract}
The thesis we put in the following text aims to study two important musical genres, the modinha and lundu, whose process of preparation to start on the second half of the eighteenth century in Luso-brasilian society. In order to provide a more comprehensive discussion of the subject, the historical, stylistic and identity aspects that are very important to the historiography of music in Portuguese speaking countries, are taken into consideration here. In order to observe address the complexity of our object of study, we based our methodology especially in the study of history, combined with historical musicology, systematic musicology and also to ethnomusicology. Acknowledging that the genres in question, the object of our study are related to the transformations in the Luso-Brazilian society and in the international aesthetic conceptions, we identify them with what turned out to be called the aesthetic sentiment or sentimentalism, and the classical style that developed in Europe during the eighteenth century, both in poetry and music, and that built, gradually other modes of production and reception, identified with a new way of bourgeois sociability that will dominate the century of the enlightenment. On the other hand, we seek also to understand what aspect of popular culture participated for the formation of these genres, and consequently how is this impact on musical expression common to both already evident in the period of their origin. From the study of historiography related to the genres in question, as we seek to establish how modinha and lundu have participated in the discussions about national identity, yet steeped in positivist and nationalists thoughts of the $19^{\text {th }}$ century that remains in significant part of the the literature of the $20^{\text {th }}$ century. And finally, when we discuss about the performance, using sources such as musical recordings from the 1950s, sought to identify aesthetic and ideological currents present in these records, which we shall call interpretative paradigms.
\end{abstract}

Key words: modinha and lundu; history of Brazilian music, aesthetics and enlightenment/illustration, music and ideology, music performance. 


\section{A modinha e o lundu: dois clássicos nos trópicos}

1. Introdução 10

2. Modinha, lundu, ilustração e cultura urbana nos últimos anos do século XVIII e primeiros anos do século XIX

2.1. A modinha e o lundu: conjuntura histórica e musical .15

2.1.1. As chulices do lundu ............................................................. 20

2.1.2. Rumo ao lundu cancã ............................................................. 28

2.1.3. A moda das cantigas ou a música nos salões ...................................... 33

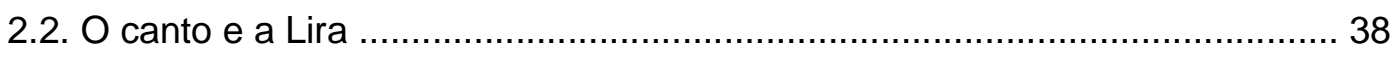

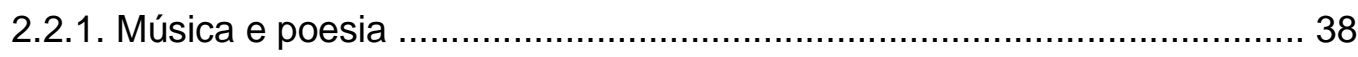

2.2.2. Cultura burguesa, simplicidade e lazer ............................................. 42

2.2.3. Melodia, sentimento e natureza .................................................... 43

2.2.4. Poesia e música ......................................................................... 45

2.2.5. Textos de modinhas de autores desconhecidos .................................. 55

2.2.6. O Lundu: poesia popular e ilustração ................................................ 56

2.2.7. Outros exemplos de formas poéticas ............................................ 58

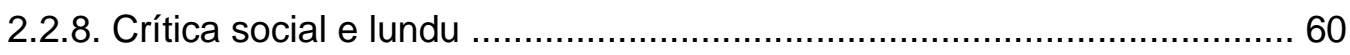

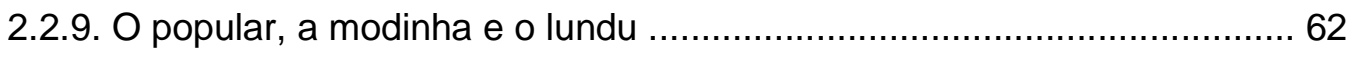

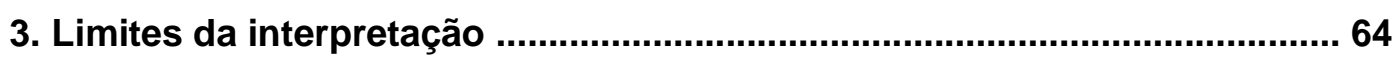

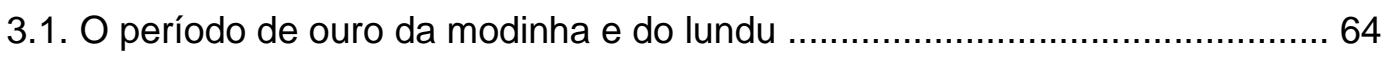

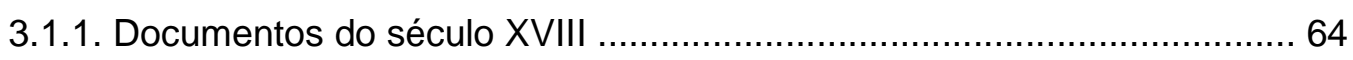

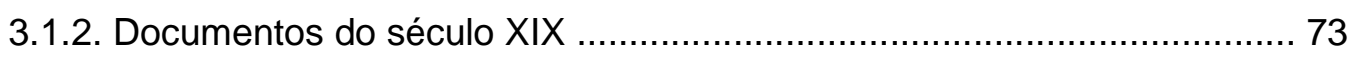

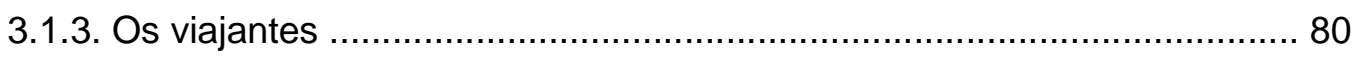

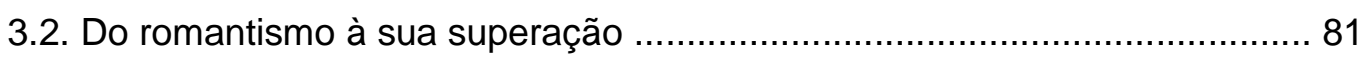

3.2.1. Antecedentes no século XIX e a virada para século XX ......................... 81

3.2.2. A semana de arte moderna e a orientação pós 1922 .............................. 85

3.2.3. Desdobramentos do projeto modernista ........................................... 95

3.2.4. Rumo à ultrapassagem do romantismo ............................................... 99

3.3. A modinha e o lundu: 50 anos de registros musicais ............................ 101

3.3.1. Romantismo: a imagem sonora do amor brasileiro ............................... 101

3.3.2. Modinha, lundu e folclore: as raízes do Brasil?..................................... 105

3.3.3. Modinha, lundu e música popular urbana ............................................. 109

3.3.4. O movimento da música antiga e a música colonial: barroquismo versus classicismo 


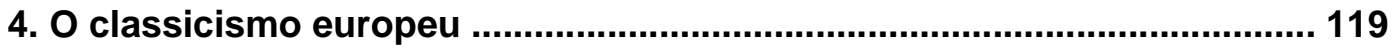

4.1. Formação e afirmação ....................................................................... 119

4.2. O natural e o simples como modelo ...................................................... 124

4.3. Música religiosa e estilo clássico ....................................................... 125

4.4. A Popularização da música no século XVIII ............................................. 126

4.4.1. Música para não profissionais ........................................................ 126

4.4.2. Concertos públicos e intermezzi .............................................. 128

5. 0 estilo clássico nos trópicos ................................................................. 131

5.1. Formalismo, simetria e modas da terra ............................................... 131

5.1.1. O formalismo clássico e a modinha ..................................................... 132

5.1.2. Seção única .......................................................................... 133

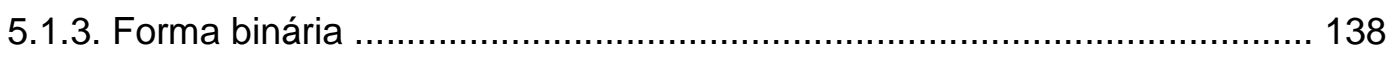

5.1.4. Forma Ternária ........................................................................... 144

5.1.5. Belcantismo e canto natural ............................................................ 154

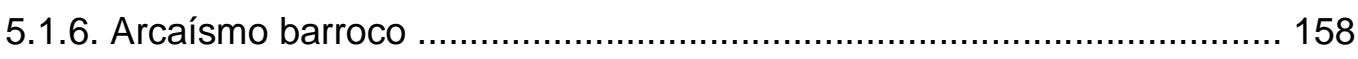

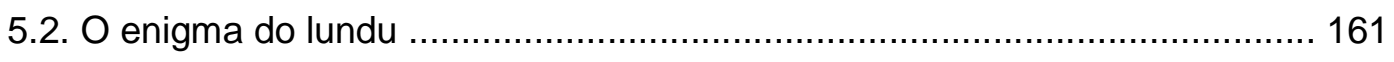

5.2.1. O lundu, sua iconografia, sua música ............................................ 161

5.2.2. A dança do lundu e a ausência de partituras ..................................... 197

5.2.3. A questão da síncope ................................................................... 198

5.2.4. O lundu canção: ornamento-monumento ........................................ 205

5.2.5. O batuque e o lundu ................................................................ 206

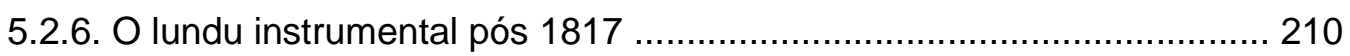

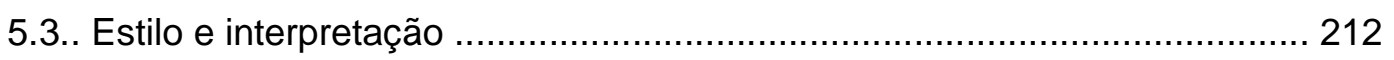

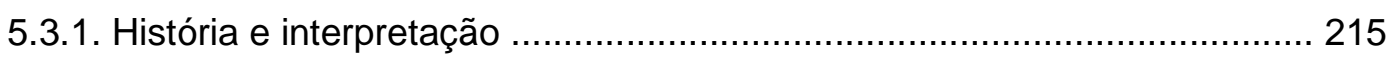

5.3.2. "Performance historicamente informada" ou o controle do paradigma

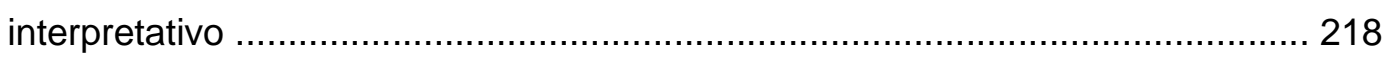

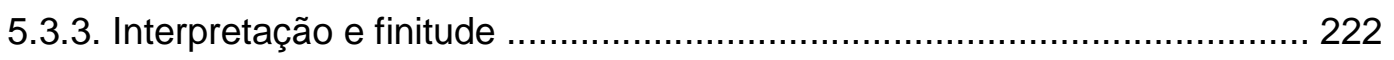

5.3.4. A modinha e o lundu: uma poética possível ......................................... 223

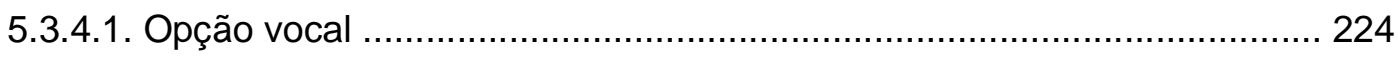

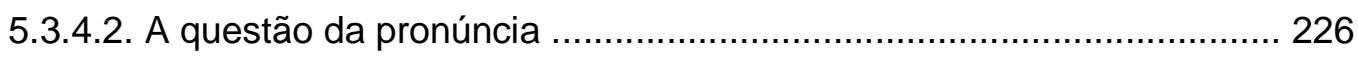

5.3.4.3. Opção instrumental .............................................................. 227

5.3.4.4. Improviso e ornamentação ..................................................... 228

6. Conclusão ................................................................................................. 230

7. Referências Bibliográficas ...................................................................... 238

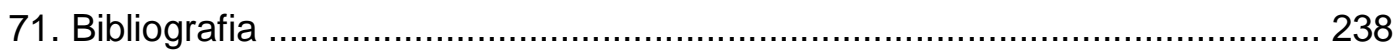


7.2. Arquivos

246

7.3. Registros musicais .

$\bullet$ 
"As mestiçagens nunca são uma panacéia; elas expressam combates jamais ganhos e sempre recomeçados. Mas fornecem o privilégio de se pertencer a vários mundos numa só vida" (Serge Gruzinski, O pensamento mestiço) 


\section{Introdução}

A modinha e o lundu são dois gêneros musicais que têm acompanhado a história da música luso-brasileira já há mais de dois séculos. Gêneros abordados por músicos de renome, tais como Marcos Portugal (1762-1830), Antonio Leal Moreira (1758-1819), José Mauricio Nunes Garcia (1767-1830); e citados, já no século XVIII, por poetas e viajantes, tais como Nicolau Tolentino de Almeida (1740-1811), William Beckford (1760-1844), dentre outros, tornaram-se veículos da expressividade da época, difundindo-se rapidamente em todas as classes sociais, sem distinção, antes mesmo do alvorecer do século XIX.

Justamente por transitarem nas várias camadas sociais, a modinha e o lundu tornam-se pivôs da inter-relação de classes, ora abrindo portas, aproximando atores sociais de camadas menos favorecidas, como os mulatos Domingos Caldas Barbosa (1740-1800) e Joaquim Manuel da Câmara (fl. séc. XVIII-XIX), veiculando características da colônia para a metrópole; ora efetuando este mesmo caminho no sentido inverso; por vezes, causando celeuma e despertando a fúria de poetas, como no caso da intriga envolvendo Manuel Maria Barbosa du Bocage (1765-1805) contra nossos modinheiros mulatos (Cf. FAGERLANDE, 2008).

Portanto, o texto que segue é uma tentativa de compreender o lugar ocupado pela modinha e pelo lundu, dois gêneros seculares que, como sugerido anteriormente, transitaram tanto nas camadas altas como nas camadas menos favorecidas da sociedade, não somente como práticas musicais, mas também como se inserem dentro do contexto social, histórico, e estético do final do século XVIII e primeiro quartel do século XIX. Considerando-se a situação de dependência administrativa da colônia brasileira dentro do panorama político-social da época, nossa abordagem só faria sentido a partir de uma discussão que situasse os gêneros em questão no interior do panorama musical internacional, ou seja: quais foram os fatores que atuaram para o surgimento desses gêneros, em Portugal e no Brasil, e sua inserção no interior das realizações musicais em curso na Europa do mesmo período. 
É evidente que ao pesquisar o passado, acabamos sempre por relacioná-lo com o presente, sobretudo com o nosso presente. Mas nossa intenção não foi, de modo algum, uma tentativa de estabelecer novos mitos fundacionais a fim de explicar nossas felicidades ou penúrias no presente; não obstante nossa consciência de que esta tendência foi, e tem sido uma busca constante não só na história musica brasileira. Atribuímos a isso dois motivos: primeiro porque já não acreditamos numa história linear e unívoca: a história é fugidia, na maioria das vezes plural (JENKINS, 2007) e não raro descontínua (FOUCAULT, 1979); segundo, exatamente por não perseguirmos uma linearidade histórica, a preocupação central foi o entendimento do que estes gêneros significaram para a sociedade de fins do século XVIII e início do XIX, sem nos atermos, num primeiro momento, se suas características serão cultivadas (ou não) dentro de uma suposta tradição futuramente imaginada.

Nesse sentido, uma compreensão da época em que surgem e se estabilizam como gêneros musicais - o último quartel do século XVIII e o primeiro do século XIX - será de importância capital: os últimos anos do que fora denominado o século das luzes e que de modo algum se esgotará nos primeiros anos do século seguinte, o qual, por sua vez, será marcado na música pelo advento do Romantismo. É no século XVIII que a disciplina estética se emancipa e traz à tona, não só a figura do burguês como sua contraposição, o proletário. E é também neste século que, ao focalizar a sensação e o sentimento como a base fundamental para a esfera artística (JIMENEZ, 1999), promovendo uma cultura secular, somos afastados gradativamente do ideal ético-pedagógico da arte barroca, colocando, a partir de então, o ser humano como o centro das realizações: do qual a arte emana e ao qual a arte se dirige.

É evidente que o humano idealizado pela cultura ilustrada deve ser cuidadosamente forjado: não é mais aquele homem místico do século passado e nem o camponês rústico, embora este traga consigo a proximidade com a natureza, uma das bases da estética da época; mas um ser sofisticado que sabe ver na natureza não só o simples, o agradável, mas também o equilíbrio das forças racionalizáveis. E para isto, é preciso ser reeducado não somente por uma nova escola fundamentada nas ciências naturais esclarecedoras e no humanismo clássico, claro e lúcido; mas também por uma arte refinada, leve e 
que fale direto ao coração, o receptáculo do sentimento, e que possa ser inteiramente absorvida pelo intelecto. E não é por outra razão que em França se estabelecem as querelles em meados do século: buffonisti, os defensores da ópera buffa, a favor de uma música simples, com melodia "natural" e deleitável, versus antiboffonisti, os defensores da tragédie lyrique, a favor da ópera séria e com conteúdo moralizador (FUBINI: 1987).

Nesse contexto a ópera despontará como elemento civilizador, como defendido por Mário Vieira de Carvalho (1993), e será a grande escola da construção não só do gosto, mas também de um modus vivendi adaptado a esta nova era: civilizada e sensível, secular e racionalista. Neste aspecto, a modinha e o lundu, como destacado por Machado Neto (2008) e neste presente texto, integrarão essa escola de boas maneiras; mas não sem ressalvas. Deste modo, buscamos uma interpretação calcada no projeto ilustrado lusitano pós-pombalino como matriz, suas possíveis adaptações à realidade social da época e como a modinha e do lundu participam dessas transformações.

Para esse intento, optamos por um estudo que levasse em conta não somente documentos primários: manuscritos, edições princeps, relatos de viajantes e poetas da época; mas também a literatura que tem retratado a história desses gêneros em território brasileiro e português no século $X X$. Registros iconográficos, como aquarelas e litografias do século XIX, sobretudo aqueles que retrataram funções musicais, como danças relacionadas com 0 lundu e o batuque, foram objeto de nossas interpretações. Evidentemente não tomamos tais "retratos" com olhar inocente; ou seja, há neles muito comprometimento, muita idealização. Foram considerados, também, os registros musicais efetuados a partir de certo momento da história dos dois países ligados aos gêneros em questão, Brasil e Portugal, pois entendemos que os registros sonoros também estão inseridos em universos interpretativos históricos, portanto comprometidos com o tempo e com visões de mundo; em suma, com modelos de performance.

A historiografia sobre a modinha e o lundu, foi sem sombra de dúvida, nosso norte. Nesse sentido, intentamos um diálogo com textos desde o início do século XX e publicações mais atuais. Foi por esta razão que buscamos, já nas primeiras páginas de nosso texto, uma recomposição da história da 
modinha e do lundu, sua ligação com o mundo luso-brasileiro, destacando o modo como surgiram e como foram absorvidos na sociedade da época. Ainda no mesmo capítulo, procuramos analisar o texto poético que dá conteúdo ao gênero em questão. Neste caso, buscamos não só uma aproximação da cultura do arcadismo, mas também das características populares vinculadas à cultura negra e, por vezes, indígena. As acomodações musicais na elaboração da fraseologia do lundu demonstram uma forte tendência para a anacruse, a síncope e os finais femininos como veremos no capítulo dedicado a essa questão; na poesia que se liga a este gênero os coloquialismos advindos da influência negra e "negros da terra" (índios), se farão presentes, e de modo bastante enfático. Nesse sentido, a cultura ilustrada, esse "sistema-mundo" intelectual e, portanto, artístico do século das luzes, tentará clarear qualquer vislumbre de obscurantismo e irracionalidade e integrar-se-á na sociedade, também deste lado do Atlântico, nem sempre com absoluta eficácia.

Uma discussão aproximando a poesia e a música, não poderia ser omitida neste trabalho, já que os gêneros estudados, o lundu e a modinha, são canções, ou seja, obras musicais efetuadas para serem cantadas, sobre texto poético. Por tal motivo dedicamos parcela do primeiro capítulo a discussões sobre o estilo dos poemas, em lugar de discussões estruturais, sobretudo por entendermos que a opção pela forma (quantidade de versos e sílabas da estrofe, a questão da rima e ritmo etc.) não está desligada de um comprometimento estilístico, ou seja, estético.

No segundo capítulo tentamos capturar como a modinha e o lundu participam, num primeiro momento, das discussões relacionadas à questão da identidade nacional no início do século $X X$ e seus desdobramentos futuros. Neste caso, refletimos sobre a concepção de meio, raça e folclore, em fins do século XIX e como estes conceitos continuaram vigentes na literatura do século $\mathrm{XX}$, norteando o projeto modernista e se ligando ao ideal nacionalista coevo.

Dedicamos ao quarto capítulo, O classicismo europeu, para a compreensão dos aspectos que consideramos fundamentais na consecução desse estilo. Mas de nenhum modo entendemos que a busca de equilíbrio e contrastes formais e emocionais, e a super valorização da melodia, possam ser compreendidos fora de uma dimensão estética. A partir do capítulo que segue, O estilo clássico nos trópicos - dividido em Simetria, formalismo e modas da 
terra, O enigma do lundu e Estilo e interpretação - não mais nos distanciamos do estilo clássico como uma das perspectivas centrais que deram suporte estrutural e estético para a compreensão da modinha e do lundu como gêneros musicais na época em questão. Mas de modo algum vamos prescindir de uma compreensão dos elementos advindos das classes populares da época, discutidos mais enfaticamente no segundo texto deste capítulo, $O$ enigma do lundu. Deste modo, cultura de elite e popular, como tem atestado as informações já na época do surgimento de ambos os gêneros, tanto em sentido poético quanto em sentido musical, se imbricam no final dos setecentos na consecução dos gêneros em questão e, sobretudo, no lundu. Nesse sentido, o texto que segue é, como acenamos mais acima, uma tentativa de recolocar todas essas questões, todavia, com olhares diversos. 


\section{Modinha, ilustração e cultura urbana nos últimos anos do século XVIII e primeiros anos do século XIX}

\subsection{A modinha e o lundu: conjuntura histórica e musical}

A modinha e o lundu estão ligados à história do expansionismo lusitano, que tem seu início, como sabemos, com a lógica expansionista do renascimento. Dizendo de outro modo, pensar a história, e por consequência a cultura brasileira, é refletir como Portugal, ao longo de vários séculos, buscou implantar em suas colônias em todo o mundo, uma cultura européia, monárquica, capitalista e calcada, evidentemente, em seus próprios anseios, ou seja, lusitana. E mais do que isto: trata-se de compreender como após a primeira metade do século XVIII, as tendências da administração pombalina, juntamente com modelos sócio-culturais ilustrados foram articuladas pelas camadas sociais luso-brasileiras; e como se refletiram também na construção de formas de lazer, portanto na construção de um modus vivendi, que irá influenciar diretamente, após a segunda metade dos setecentos, gêneros musicais tais como a modinha e o lundu, tema central deste texto. Mas também, como a sociedade deste lado do Atlântico foi, ao longo dos anos, forjando sua própria história, ou seja, buscando seus próprios caminhos e construindo paulatinamente, e mesmo que isto não tenha representado num primeiro momento uma ruptura, seus próprios modos de expressividade, adequando-os e adaptando-os aos gêneros em questão.

É evidente que atuar nas colônias não significava tão somente impingir uma cultura de cima para baixo sem fazer concessões; mas também negociar, quando preciso, com os atores locais (SOUSA, 2006; RUSSEL-WOOD, 2000). E é, sem dúvida, dessa maior ou menor abertura para negociações com a sociedade colonial, que serão construídas formas de sociabilidade. É a partir deste entendimento que interpretamos a história da modinha e do lundu na cultura luso-brasileira da segunda metade do século XVIII: a modinha, como canção lírica, que tematiza o amor ideal, poética e musicalmente comprometida com o estilo vigente na segunda metade do século XVIII; e o lundu, canção mais sensual, satírica, e às vezes crítica, também comprometida com sua época, às vezes espúria e um pouco marginal; mas comprometida com o 
projeto ilustrado civilizador que tem início com o marquês de Pombal, não interrompido na Viradeira, onde a ópera no espaço público e, por conseqüência a modinha e lundu, farão parte da disseminação de uma cultura ilustrada, laica e liberal, não sem confronto, evidentemente, com visões mais conservadoras (NERY \& CASTRO, 1999, p. 118).

Como assinala Mário Vieira de Carvalho, a função do teatro "era, pois, um investimento na sociabilidade. Esta é que deveria ser lucrativa" (VIEIRA DE CARVALHO, 1993, p. 45), destacando, portanto, "os fins educativos do teatro" (Ibidem, p. 45). E esta educação postulada pelos novos dirigentes neste final do século XVIII era, certamente, uma educação ilustrada, portanto, burguesa; e, se não tinha como meta a derrocada do catolicismo lusitano, necessitava desenvolver na sociedade como um todo, e também nas classes menos favorecidas, valores profanos, que na arte e, consequentemente na música, estavam ligados a novas concepções já em voga na estética européia, e que serão denominados como período clássico. Este vai sistematizar suas conquistas na busca de formalismo simétrico, na minimização do contraponto e, especialmente, na ênfase da melodia configurada em frases articuladas e periódicas (ROSEN, 1986). E não somente isso, mas também no que se denomina a estética do sentimentalismo, ou Empfindsamkeit, entendida como uma espécie de "rebelião contra a ordem estabelecida" (VIEIRA DE CARVALHO, 1999, p. 31), o obscurantismo religioso e os modelos cosmogônicos do absolutismo barroco, e tornar-se-á o novo paradigma da época das luzes.

Nessa nova concepção, o ser humano racionalmente consciente, mas não sem ignorar seu lado sensitivo e sentimental, será o centro das preocupações artísticas. É nesse sentido, como afirma Vieira de Carvalho que:

"O afeto deixa de ser um processo sabiamente administrado pelo músico, qual orador que domina as diferentes figuras de retórica: a condição primeira, agora, é que ele seja verdadeiramente sentido, vivido, pelo compositor, pelo intérprete e pelo público" (Ibidem, pp. 31-32).

E mais do que isto: se o século das luzes impunha uma reforma contra a irracionalidade e o obscurantismo, fazia-se necessária a criação de todo um aparato "iluminador" que pudesse clarear os pensamentos, polir as almas, sensibilizar os corações; em suma, sociabilizar as convivências. Nesse sentido, 
a expulsão dos jesuítas, num primeiro momento, insere-se dentro dessa lógica (Neto, 200 p. 235):

Deste modo, "secularizar os estudos 'menores' criando as aulas régias de Latim, Grego e Retórica, por decreto de 1759" (Ibidem, p. 236), que seriam ministradas por professores leigos, foi um primeiro passo para o intento de secularização da cultura com ênfase numa tendência absolutamente humanística e calcado em autores clássicos (Ibidem, p. 237). Portanto, a reforma do teatro de ópera e sua guinada para um modelo iluminista (VIEIRA DE CARVALHO, 1999), e o investimento numa cultura de "entretenimento", visava levar ao convívio público outro modo de sociabilidade, um verdadeiro papel educador, pedagógico.

A modinha e o lundu, portanto, despontam como gêneros musicais dentro desse contexto, ou seja, absorvendo toda complexidade das mudanças ocorridas após a subida de Sebastião José de Carvalho e Melo, o Marquês de Pombal, depois do terremoto que abalou Lisboa em 1755. Antes dessa data, canções em Portugal eram classificadas genericamente de romance, ária, cantiga ou moda (ARAUJO, 1963). Mas, no último quartel do século XVIII, o substantivo "modinha" aparece cada vez mais com freqüência na literatura musical e poética, porém, de modo algum, descartando os substantivos precedentes. Os substantivos moda, cantiga e até mesmo cançoneta (este para destacar uma influência diretamente italiana), continuam sendo utilizados, como podemos atestar nos manuscritos da época e na própria produção poética de Domingos Caldas Barbosa, um dos atores mais citados na história desse gênero (BARBOSA, 1980 e 2003). Porém, cada vez com mais freqüência, a canção de amor luso-brasileira dessa época será conhecida com o nome de modinha. Não é por outra razão que o periódico dedicado a este gênero, e que será publicado entre os anos de 1792-1796, será denominado Jornal de Modinhas (ALBUQUERQUE, 1996), apesar das peças em seu interior, muitas vezes, virem identificadas pela denominação moda, duo, duetto, além de modinha.

Na verdade, a classificação de modinha, só será usada meia dúzia de vezes nos cinco anos de publicação do Jornal de Modinhas. Portanto, as palavras moda e modinha configuram-se como sinônimos; uma espécie de denominação genérica para a canção de amor luso-brasileira do último quartel 
do século XVIII. Curioso é notar na peça de número 14 que, na página de rosto, aparece denominada como Moda do Zabumba del sig. ${ }^{r}$ Antonio Leal Moreira, mas na página onde consta a separata para uma terceira voz, vemos a seguinte denominação: Terceira vos da Modinha do Zabumba Del Sinhor Antonio Leal Moreira (Ibidem, 1996, p. 35), acusando, deste modo, a indistinção entre os dois termos.

Também no códice Muzica escolhida da viola de Lereno (BARBOSA, 2003[1799]), o vocábulo modinha, somente aparece três vezes, ao lado de denominações como duo, romance, e indicações de andamento, Andante, Allegro, Adagio, Adagio não muito e Moderato. Já o manuscrito Modinhas do Brasil, também datado de fins do século XVIII (BEHAGUE 1968; LIMA, 2001), não há denominações referentes aos gêneros das canções em seu interior, já devidamente classificas no título do códice; apenas constam nas últimas peças do manuscrito indicações referentes aos respectivos andamentos, como Moderato, Largo e Andante.

Não obstante essa profusão de classificações, a cantiga de amor desse final de setecentos, será cada vez mais conhecida como modinha, sobretudo em denominações de poetas e viajantes da época: no livro de Domingos Caldas Barbosa, Viola de Lereno: coleção das suas cantigas oferecidas aos amigos, que teve primeira publicação do volume I em 1798, e volume II, somente em 1826, a classificação de modinha, somente será usada um vez, como subtítulo do poema Marília brasileira nas caldas (Ibidem, p. 232). Transcrevemos abaixo a primeira estrofe:

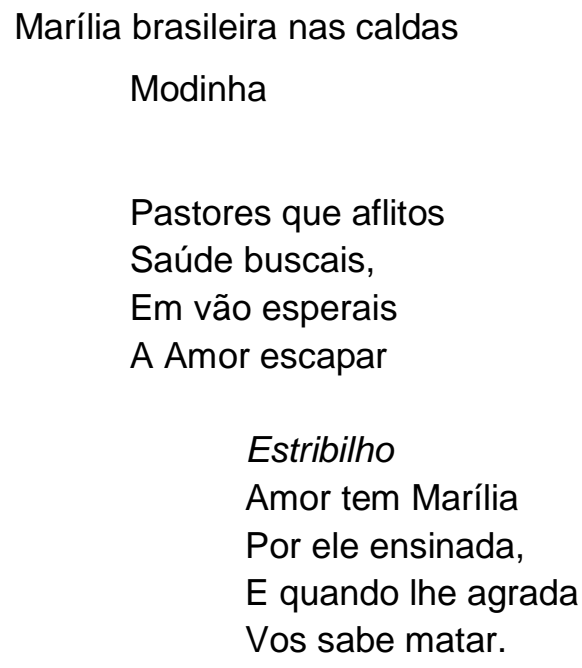

Estribilho

Amor tem Marília

Por ele ensinada,

E quando lhe agrada

Vos sabe matar. 
Porém aparece citada em versos internos de poemas, como por exemplo, em Recado (Ibidem, p. 44-46), e que fora musicado por Antonio José do Rego com acompanhamento de P. A. Marchal, publicado no primeiro ano de circulação do Jornal de Modinhas, portanto em 1792. Abaixo, transcrevemos a estrofe terceira, onde aparece o substantivo modinha com significado de canção:

Cantou algumas modinhas?

E que modinhas cantou?

Lembrou-lhe alguma das minhas?

Não, não;

Nem de mim mais se lembrou:

O amor antigo

Já lhe passou,

E a fé jurada?

Tudo gorou.

Nicolau Tolentino de Almeida (1722-1804), em alguns de seus poemas, também cita a modinha como sinônimo de canção (Apud Nery, 2005, p. 34):

Já dentre as verdes murteiras,

Em suavíssimos acentos,

Com segundas e primeiras,

Sobem nas asas dos ventos

As modinhas brasileiras

E em outro poema, desta feita, destacando negativamente a vulgaridade da modinha brasileira (Apud Nery, 2005, p 34):

Cantada a vulgar modinha,

Que é dominante agora,

Sai a moça da cozinha

E diante da senhora

Vem desdobrar a banquinha.

Outros expectadores da época, como por exemplo, William Beckford, na década de 1780, efetua uma das mais apaixonadas declarações às modinhas, enaltecendo, diferentemente de Nicolau Tolentino, sua delicadeza, languidez e poder de sedução, mas de modo positivo: 
"Aqueles que nunca ouviram modinhas terão de permanecer e permanecerão na ignorância da música mais voluptuosa e mais enfeitiçadora que já existiu desde os tempos dos sibaritas." (Apud Nery, 2005, p. 34).

Também a incorporação desses dois gêneros nos espetáculos teatrais, como entremez, deste e daquele lado do oceano, não somente incrementou sua produção, como contribuiu para sua difusão e aceitação (FAGERLANDE, 2008; NERY, 1999; TINHORÃO, 2004) nas classes populares. Guardadas as devidas proporções com a realidade intercultural nos dias de hoje, não só Lisboa, mas o Rio de Janeiro, ainda mais após a transferência da corte em 1808, deviam ser cidades fervilhantes aos olhos de seus habitantes, ou daqueles que por ali passavam. E como bem destacado por Peter Burke em seu pequeno texto Hibridismo cultural (2003), as cidades serão locais privilegiados para as trocas, para os desvios, para a construção de novos gêneros e, consequentemente, para o surgimento de alteridades. E será da interação dessa diversidade intercultural do último quartel do século XVIII que surgirá o lundu, também em sua forma cantada, como se discutirá abaixo.

\subsubsection{As chulices do lundu}

O lundu será fruto da mesma complexidade da época destacada acima, porém nascido na colônia, surge

"inicialmente, como forma de dança no século XVIII e seu aparecimento está inicialmente ligado ao processo de colonização brasileiro e imbricado, sobretudo, na confluência das culturas européias, via Portugal e Espanha, bem como a cultura africana trazida como mão de obra escrava, nos primeiros séculos de colonização". (LIMA, 2006, p. 100).

Suas bases coreográficas, segundo pesquisadores, trazem elementos do fandango, dança de origem ibérica ${ }^{1}$ muito em voga na América Latina durante o século XVIII, tais como os estalidos dos dedos à guisa de castanhola, a alternância das mãos ora nos quadris e ora na testa e o caminhar na ponta dos dedos dos pés (KIEFER, 1977: 34); já o balanço das ancas, o popular

\footnotetext{
${ }^{1}$ Fandango, popularmente dançado tanto na América Espanhola, quanto na América portuguesa, tem origem na Península Ibérica no período da União Ibérica. Há ainda outra vertente que classifica o fandango como tendo origem na América Latina e levado à Península Ibérica no início do século XVIII. (Fonte: Museu do Fandango. www.museuvivodofandango.com.br/, pesquisado em 20/01/2010, às 14 horas).
} 
rebolado, e a umbigada $^{2}$, ou seja, o choque do ventre por parte do par de dançarinos serão reputados como de origem negra (Ibidem,p. 100).

Nesse sentido, o texto introdutório de Guilherme de Camargo para o CD O amor brazileiro: modinhas e lundus do Brasil (França: K617: França-Brasil, 2004), veicula informações completamente desatualizadas sobre a modinha e o lundu. Logo no inicio, afirma: "A moda e a modinha são, desde pelo menos o século XVII, testemunhas privilegiadas do complexo movimento de troca cultural entre Brasil e Portugal" (CAMARGO, 2004, p. 13). Mas abaixo, na mesma página, outra afirmação inadequada: "Vários autores indicam o século $\mathrm{XVI}$ como origem do gênero". Porém, ao efetuar suas afirmações, nunca citando as fontes teóricas. Já em relação ao lundu, Camargo afirma: "No século XVII o lundu teria perdido seu caráter coreográfico transformando-se em música para ser cantada" (Ibidem, p. 14).

Segundo a visão que estamos defendendo, tanto a modinha quanto o lundu são gêneros que surgem da complexidade sócio-cultural após a segunda metade do século XVIII (NERY, 2005; BARBOSA, 203; LIMA, 2001; CRUZ, 2000; TINHORÃO, 1991, 1998 e 2004). Outro fato é que o lundu não deixa de ser dançado no século XVII, nesta época ele nem havia se configurado como gênero autônomo. O que aventamos, é que Camargo está seguramente confundindo as discussões referentes aos calundus do século XVII (LIMA, 2006; TINHORÃO, 1998; SOUZA, 1986) com o lundu de fins do século XVIII, que será dançado e cantado fartamente no Brasil e em Lisboa não só nesse final de setecentos; como persistirá durante o século XIX, adentrando as revistas e espetáculos de circo até início do século $\mathrm{XX}$, tendo com um dos representantes o famoso Xisto Bahia, 1841-1894 (KIEFER, p. 1977); isso porque estamos tratando de sua trajetória nos centros urbanos. Portanto, Guilherme de Camargo demonstra uma total desatualização em relação às pesquisas atuais referente ao lundu como gênero musical e como forma de dança; além disso, o fato do texto ter sido inserido no encarte de um CD ligado às comemorações do Ano do Brasil na França agrava ainda sua divulgação. Mas, voltemos à nossa trilha principal.

\footnotetext{
${ }^{2}$ A umbigada já se configurava como característica de danças já no século XVII no Brasil, como por exemplo "cãozinho" e o "paturi", danças praticadas na Bahia no final do século XVII e descritas nos poemas de Gregório de Matos, 1636-1695. (BUDAZS, 2004).
} 
Evidentemente que havia negros na corte (TINHORÃO, 1997), mas o Brasil, pelas adaptações da administração portuguesa nestas terras, pela maior dificuldade do controle social devido à distância com o centro de decisões, pelo contingente de não lusitanos, como índios e, sobretudo negros (NETO, 2008; SOUZA, 2006 e 2009; RUSSEL-WOOD, 2000), ofereceu condições de trocas interculturais menos rígidas, e por essa razão o lundu pode desenvolver-se, não sem conflitos com a moral católica vigente na época, deste lado do Atlântico. E tal e qual a modinha, também será citado por poetas e viajantes, e nesse sentido, a crônica efetuada por Tomás Antonio Gonzaga em suas Cartas Chilenas (2006[1786]. p. 156), é de suma importância:

\footnotetext{
Chegam-se enfim as horas, em que o sono

Estende na Cidade as negras asas

Em cima dos viventes, espremendo

Viçosas dormideiras. Tudo fica

Em profundo silêncio; só a casa,

A casa. Aonde habita o grande Chefe,

Parece, Doroteu ,que vem abaixo.

Fingindo a moça, que levanta a saia,

E voando nas pontas dos dedinhos,

Prega no machacaz de quem mais gosta,

A lasciva embigada, abrindo os braços:

Então o machacaz mechendo a bunda,

Pondo uma mão na testa, outro na ilharga,

Ou dando alguns estalidos com os dedos,

Seguindo das violas o compasso,

Lhe diz: "eu pago, eu pago"; e de repente

Sobre a michela atira o salto.

Ó dança venturosa! tu entravas

Nas humildes choupanas, onde as negras,

Aonde as vis mulatas, apertando

Por baixo do bandulho a larga cinta,

Te honravam cós marotos, e brejeiros,

Batendo sobre o chão o pé descalço.

Agora já consegues ter entrada

Nas casas mais honestas e Palácios
}

Neste trecho, extraído da Carta 11ạ, que de modo algum tem sentido enaltecedor, mas negativo, não só a descrição da dança com toda sua carga dramática e requebros, malemolências e umbigadas, além da sugestão do acompanhamento "das violas"; mas também seu trânsito entre as "humildes choupanas", as "casas mais honestas" e os "palácios", destaca por quais camadas sociais transitava a "dança venturosa". Em outro poema, desta vez de Nicolau Tolentino de Almeida (Apud NERY, 2005, p. 29), também de fins do 
século XVIII, essa interculturalidade entre camadas sociais diversas, será destacada em sua presença também nas festas religiosas ligadas a São Gonçalo e Nossa Senhora do Rosário, a padroeira dos "pretos":
Em bandolim marchetado
Os ligeiros dedos prontos, Loiro peralta adamado
Foi depois tocar por pontos
O doce londum (sic) chorado.
Se Márcia se bamboleia Neste inocente exercício, Se os quadris saracoteia, Quem sabe se traz silício, E por virtudes os nomeia?
Não sentenceies de estado; Têm as danças fim decente; Ama o pai; mas por deixá-lo Dança a donzela inocente, Diante de São Gonçalo.
Cobrando o pardo dinheiro De que o povo é tributário, Velho preto prazenteiro Para a glória do Rosário Remexe o corpo e o pandeiro.

Nesses saborosos versos de uma sonoridade delicada e sensual (penso que pela insistência das aliterações em "s"), o lundu se faz presente, para além das casas mais humildes, das mais honestas e dos palácios, inclusive em festas religiosas. Nesse sentido, a presença do "loiro peralta adamado" (efeminado, talvez por ter que dançar requebrando) e do "velho preto prazenteiro", mostra o grau de convivência social em torno da dança do lundu. Outra questão que merece destaque é sua descrição dos bandolins marchetados a tocar "por pontos", ou seja, dedilhando acordes alternados, como discutiremos mais à frente no texto $O$ enigma do lundu. $E$ como destaca Rui Vieira Nery em sua afirmação:

"Na transição para o século XIX a tentação irresistível das danças afrobrasileiras - e em particular o Lundum - conquistou, de facto, a sociedade lisboeta, quer estas sejam executadas na sua versão original quer tenham já sido transformadas segundo o gosto dos diversos meios sociais em que foram penetrando" (NERY, 2005, p. 29). 
De fato, o lundu - como discutiremos mais adiante- sofrerá adaptações, ou estilizações segundo a camada social em que seja praticado, aproximando essa dança dos padrões das danças cortesãs. E neste aspecto, em parte será "branqueado", como defende Machado Neto (2008), tese com a qual concordamos, mas com ressalvas: essas estilizações serão efetuadas em sua forma dançada, como podemos observar na descrição de A.P.D.G., onde, ao invés da umbigada, há a troca de lenços e onde a dança é desenvolvida por um par de mulheres:

"O landum era formalmente dançado na melhor sociedade por pessoas de ambos os sexos; mas hoje é raramente executado nos círculos mais elevados, exceto por duas mulheres, uma das quais representa o parceiro masculino. Ela consiste em graciosas cadências, com passos que são geralmente os mesmos, e a beleza dependendo principalmente do conjunto e menos dos movimentos dos pés do que da elegância graciosa e da expressiva atitude dos braços e do corpo". (A.P.D.G, 1826, p. 288).

E na passagem destacando no lenço o lugar da umbigada:

"Os parceiros colocando-se em posições opostas numa sala apropriada com o cavalheiro segurando um pequeno lenço, eles avançam para frente, um contra o outro, com graciosos passos e aspecto cortejador, e a mulher mostra-se simpática com seu admirador. Porém, no momento em que ele imagina 0 favorecimento de suas súplicas, ela afasta-se dele com um sorriso de contentamento e admiração, e na sua presunção, ele, como ela, torna para trás; porém com outro sentimento. O lenço agora encontra o caminho em seus olhos, e com desapontamento em sua feição, e com mesuras em seus passos, olhando ocasionalmente para trás para despertar compaixão" (Ibidem, p. 289)

Igualmente o que ocorreu com a coreografia licenciosa do lundu, as síncopes melódicas também serão minimizadas em algumas obras instrumentais apresentadas nos salões das classes mais abastadas, como por exemplo, o Lundu de Marruá, peça lisboeta do início do século XIX, à qual dedicaremos uma discussão mais aprofundada também no capítulo, $O$ enigma do lundu, que se comporta como um tema com variação totalmente ao gosto clássico: forma binária composta por frases de quatro compassos divididas em antecedente e conseqüente articuladas e periódicas. Porém, como mesmo A.P.D.G. destaca, esse aspecto moralizador "inoculado" nas camadas médias e altas da sociedade de fins do século XVIII e início do XIX, será escamoteado pelas camadas mais populares em suas funções fora dos salões da corte ou 
das classes médias, ou seja, em seus momentos mais livres do controle civilizador lusitano, nos terreiros e largos da cidade, onde as licenças e desvios morais continuam agindo na dança que enfeitiça, como sintetiza o mesmo A.P.D.G. dando continuidade à citação acima:

"O que acabo de tentar descrever é o landum das classes mais altas, porém quando é dançado pela ralé está longe de ser gracioso ou decente" (Ibidem, p. 289-90).

As licenças e desvios do lundu continuarão sua senda, mesmo que isso não represente uma revolta antiescravista, influenciando sub-repticiamente e se infiltrando nas danças de salão, mesmo as mais consagradas, fora e dentro do Brasil, como a polca, gerando outros gêneros musicais, como o maxixe, ou choro e futuramente o samba (KIEFER, 1979; LIMA, 2006), numa espécie de insubmissão ao racionalismo "lógico-geométrico" (NETO, 2008, p. 230) das danças de salão cortesãs. Certamente que estes desvios não podem ser comparados à revolta antiescravista do Haiti em fins do século XVIII e início do XIX, por exemplo; mas serão construções autênticas de outros modos de sociabilidade, adaptando tendências da civilização européia aqui nos trópicos à cultura popular da época e forjando, sempre que possível, seu próprio caminho e fundando, certa alteridade, pelo menos do ponto de vista musical.

Nos poemas de Domingos Caldas Barbosa, o termo lundum (sic) aparece com mais freqüência que o termo modinha, tanto inserido nos versos como nos títulos caracterizando tanto seu gênero cantado como dançado (BARBOSA, 1980) ${ }^{3}$. Mas o que mais nos interessa, é que para Barbosa, palavras como "chulice", citado nos poemas Lundum de cantigas vagas e Lundum (Ibidem, 1980: 238 e 251) aparece como um aspecto positivo: se nos versos de Gonzaga e Tolentino, o tom de sátira tem aspecto moralista, denunciando as licenças e descontroles sociais de modo negativo e que poderiam manchar a honra dos mais castiços; nos versos de Caldas Barbosa, - Lereno Selinuntino da Arcádia de Roma, há uma aceitação dessas características e o termo "chulice", assume aspecto de dengoso, com meiguice, mas também buliçoso, sensual e sedutor, como por exemplo, na estrofe sete do primeiro poema acima citado:

\footnotetext{
${ }^{3}$ Para cotizar os poemas que citam o lundu como gênero musical e de dança, Cf. BARBOSA, 1980, pp. $238,251,266,274,324$ e 348.
} 
Nhanhá cheia de chulices

Que tantos quindins afeta,

Queima tanto a quem adora

Como queima a malagueta

Ou como no terceiro verso do segundo poema citado acima:

Eu tenho uma Nhanhazinha

A melhor que há nesta rua;

Não há dengue como o seu,

Nem chulice como a sua.

E no poema Lundum em louvor de uma brasileira adotiva (Ibidem, p. 274), atesta, até quando podemos confiar no verismo dos poetas e das poesias, a naturalidade brasileira do gênero, como anteriormente destacado por Nery, mas desta feita descrevendo a dança: seus requebros, suas meiguices delicadas e sensuais:

Eu vi correndo hoje o Tejo

Vinha soberbo e vaidoso;

Só por ter nas suas margens

O meigo Lundum gostoso.

Que lindas voltas que fez

Estendido pela praia

Queria beijar-Ihe os pés.

Se o Lundum bem conhecera

Quem o havia cá dançar;

De gosto mesmo morrera

Sem poder nunca chegar.

Ai rum rum

Vence fandangos e gigas

A chulice do Lundum.

Quem me havia de dizer

Mas a cousa é verdadeira;

Que Lisboa produziu

Uma linda Brasileira.

Ai beleza

As outras são pela pátria

Esta pela Natureza.

Tomara que visse a gente

Como nhanhá dança aqui;

Talvez que o seu coração

Tivesse mestre dali.

Ai companheiro 
Não será ou sim será

$O$ jeitinho é Brasileiro.

Uns olhos assim voltados

Cabeça inclinada assim.

Os passinhos assim dados

Que vêm entender com mim.

$\mathrm{Ai}$ afeto

Lundum entendeu com eu

A gente está bem quieto.

Um lavar em seco a roupa

Um saltinho cai não cai;

O coração Brasileiro

A seus pés caindo vai.

Ai esperança

É nas chulices de lá

Mas é de cá nas mudanças.

Este Lundum me dá vida

Quando o vejo assim dançar;

Mas temo se continua

Que lundum me há de matar.

Ai lembrança

Amor me trouxe o Lundum

Para meter-me na dança.

O poema de Caldas Barbosa, transcrito neste texto quase em sua totalidade, traz muitos elementos a serem destacados: o título, Lundum em louvor de uma brasileira adotiva, indica a aceitação por porte de uma lisboeta, da dança de "sabor" brasileiro. Outro aspecto é a descrição dos olhos, da inclinação da cabeça, dos passinhos, dos saltinhos e como todo o poema está repleto de coloquialismos afro-luso-brasileiros, como "entender com mim" e "Lundum entendeu com eu". Outra questão, é que ao confrontar o lundu, o fandango e a giga, opta obviamente, pela "chulice" do lundu. É evidente que aqui o confronto é social e Caldas Barbosa, está auto-afirmando positivamente sua origem colonial e os valores de sua terra natal. Porém não vemos neste poema nenhum aspecto "nacionalista": não existe aí um projeto de autonomia nacional justificado por uma manifestação cultural, mas uma sugestão muito amena dos conflitos sociais que fizeram parte do mundo luso-afro-brasileiro, e a luta pela resistência (no sentido de persistência) de certos aspectos da 
cultura popular em confronto com o projeto "branqueador" da elite ilustrada lusitana como afirmou Machado Neto. E, na estrofe,

Ai beleza

As outras são pela pátria

Esta pela Natureza.

ao comparar a dança do lundu efetuada por uma lisboeta ("as outras") e por uma brasileira ("Esta”); e ao dar à natureza superioridade ante a pátria — a natureza, como destacado por Viera de Carvalho (1999): base da simplicidade, do verdadeiro, do coração, da arte culta, da virtude, do que está ao alcance de todos e, por fim, de sua própria negação (VIEIRA DE CARVALHO, 1993, p. 1999) - isso não soa muito aos moldes do século das luzes? Deste modo, aceito esse poema como se aceita uma saudade; e a repentina felicidade gerada pelo encontro fortuito, inesperado, com algo que não se espera rever, e toda a suposta carga emocional agregada que, por um momento, não se pode (deve) controlar; portanto algo humano, absolutamente humano! De qualquer modo, para que o lundu seja tomado também como canção ou cantiga, serão necessárias outras implicações.

\subsubsection{Rumo ao lundu canção}

Também em fins do século XVIII, quase concomitantemente com 0 surgimento do lundu em sua forma dançada, encontraremos lundus já em sua forma cantada. Porém, diferentemente da modinha que possui texto amoroso, tematizando os desejos, a saudade e os desencontros e esperanças do amor; o lundu, por sua vez, possui caráter jocoso e sensual. Ao tematizar o amor, recorre aos trocadilhos com duplo sentido e sugestões sensuais; algumas vezes, seu texto traz conteúdo crítico, enfatizando tanto a realidade política, quanto os costumes da época (LIMA, 2006, p. 105). Contudo, se os poemas utilizados como texto das modinhas sempre nos parecem idealizados; os poemas utilizados nos lundus pertencem mais ao cotidiano, à realidade do momento, os encontros dos olhares e dos esbarrões do corpo.

$\mathrm{Na}$ questão formal, o lundu se ajustará às mesmas tendências encontradas nas modinhas, ou seja, vai se comportar conforme as tendências formais desenvolvidas no século XVIII e sua busca por equilíbrio simétrico: 
formas binárias ou ternárias, com ou sem refrão; opção por frases musicais que, em sua grande maioria, obedecem aos preceitos desenvolvidos no assim chamado estilo clássico, vigente na época em questão, ou seja, articuladas e periódicas (ROSEN, 1986, p. 69).

Outra questão que merece ser destacada é a forte tendência para a síncope que, num primeiro momento, será associada à melodia, e só no século XIX aparecerá nos padrões de acompanhamento do gênero (LIMA, 2006, p. 111). Esta tendência, a nosso ver, trata-se da aplicação de ciclos ritmos advindos da cultura negra da época, e que não obedecem ao nosso padrão de contagem de tempo por divisão; mas são efetuados por adição de tempo, facilitando sobremaneira a construção de grupos rítmico-melódicos contramétricos ou sincopados, na linguagem tradicional da música ocidental, e que serão analisados no capítulo 5 como ciclos ou padrões rítmicos (MUKUNA, 2006; SANDRONI, 2001).

Esta tendência à contrametricidade ou síncope, como será discutida mais adiante, trata-se de uma verdadeira solução formalística advinda da cultura negra e equivalente à estruturação fraseológica da música ocidental. Dizendo de outro modo: houve uma adaptação dos padrões e ciclos rítmicos, tendências estruturais e formalísticas de raiz negra, à simetria formalística da música desse período. Também nesse sentido, o formalismo clássico e sua busca pela simetria, sintetizada na frase articulada e periódica de quatro compassos, facilitava as adaptações, já que sua repetição em números de pulsos, ou linhas-guias (MUKUNA, 2006; SANDRONI, 2001), eram sempre fixos. Como exemplo, transcrevemos abaixo o início do lundu Eu nasci sem coração pertencente ao códice Modinhas do Brasil (LIMA, 201, p. 87), onde sua frase inicial, completamente contramétrica ou sincopada, se comporta como se estivesse a flutuar sobre o arpejo de quatro semicolcheias efetuado pela viola de arame, à guisa de linhas guias: 

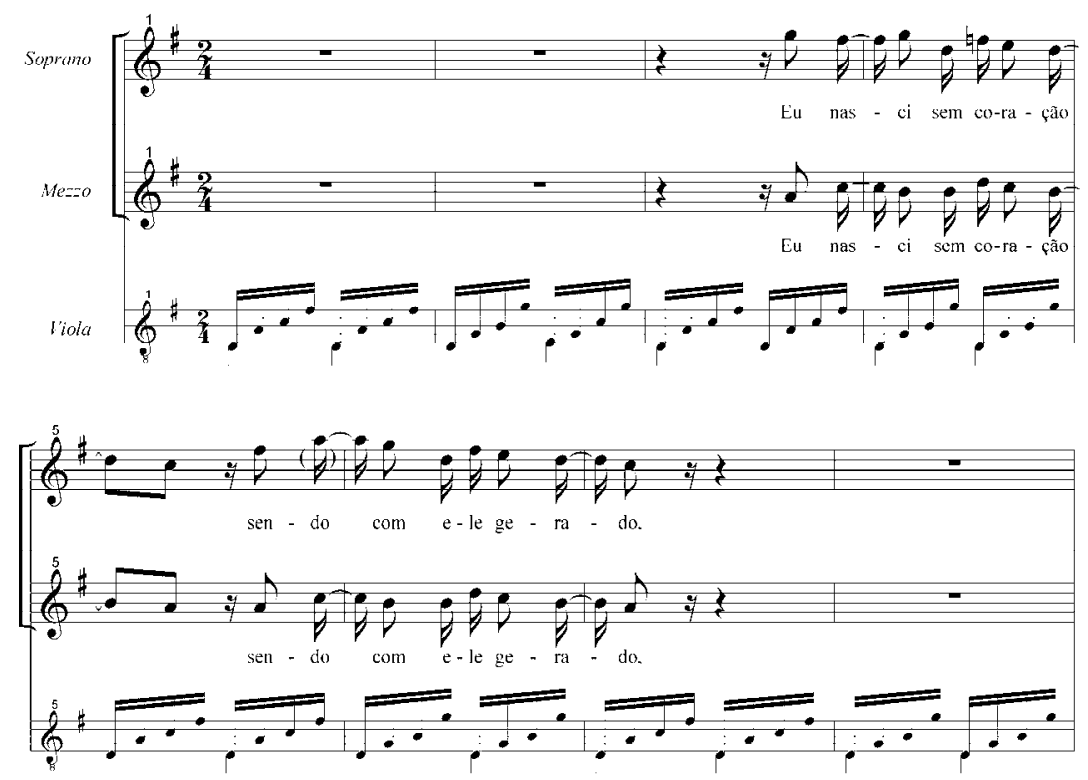

Eu nas ci sem coração (trecho), Modinhas do Brasil (LIMA, 2010)

Outras peças do mesmo manuscrito, e não somente os lundus, mas também modinhas terão se não as mesmas características, pelo menos semelhantes; porém, aprofundaremos essa discussão, como dissemos anteriormente, no texto $O$ enigma do lundu, pertencente ao capítulo $O$ estilo clássico nos trópicos. No entanto, merece ressalva a descrição efetuada pelo inglês William Beckford sobre modinhas brasileiras na ocasião de sua estada em Lisboa:

"A noite ia se aproximando, as luzes cintilam nas torres, terraços e em todas as partes do singular aglomerado de edificações de que se compõe o palácio de aspecto mourisco; metade da família se encontrava ocupada em entoar litanias de santos; a outra metade em caprichos e folganças de natureza talvez não muito edificantes: o staccato monótono da viola (guitar) acompanhado pelo murmúrio tênue e suave de vozes femininas cantando modinhas, formava, em conjunto, uma combinação de sons estranhos e não desagradáveis (...) Numa janela, imediatamente acima da fronte luzidia de Sua Reverendíssima (Arcebispo Confessor da Rainha), avistamos as duas belas irmãs (as irmãs Lacerda), damas de honor da Rainha, acenando-nos, convidativamente, com as mãos. Isto constituiu incentivo para que galgássemos vários lanços da escada, até os seus aposentos, que estavam apinhados de sobrinhos, sobrinhas e primos, aglomerados em torno de duas jovens muito elegantes, as quais, acompanhado pelo seu mestre de canto, um frade baixo e quadrado, de olhos verdes, cantavam modinhas brasileiras." (Apud ARAUJO, 1963, p. 41) 


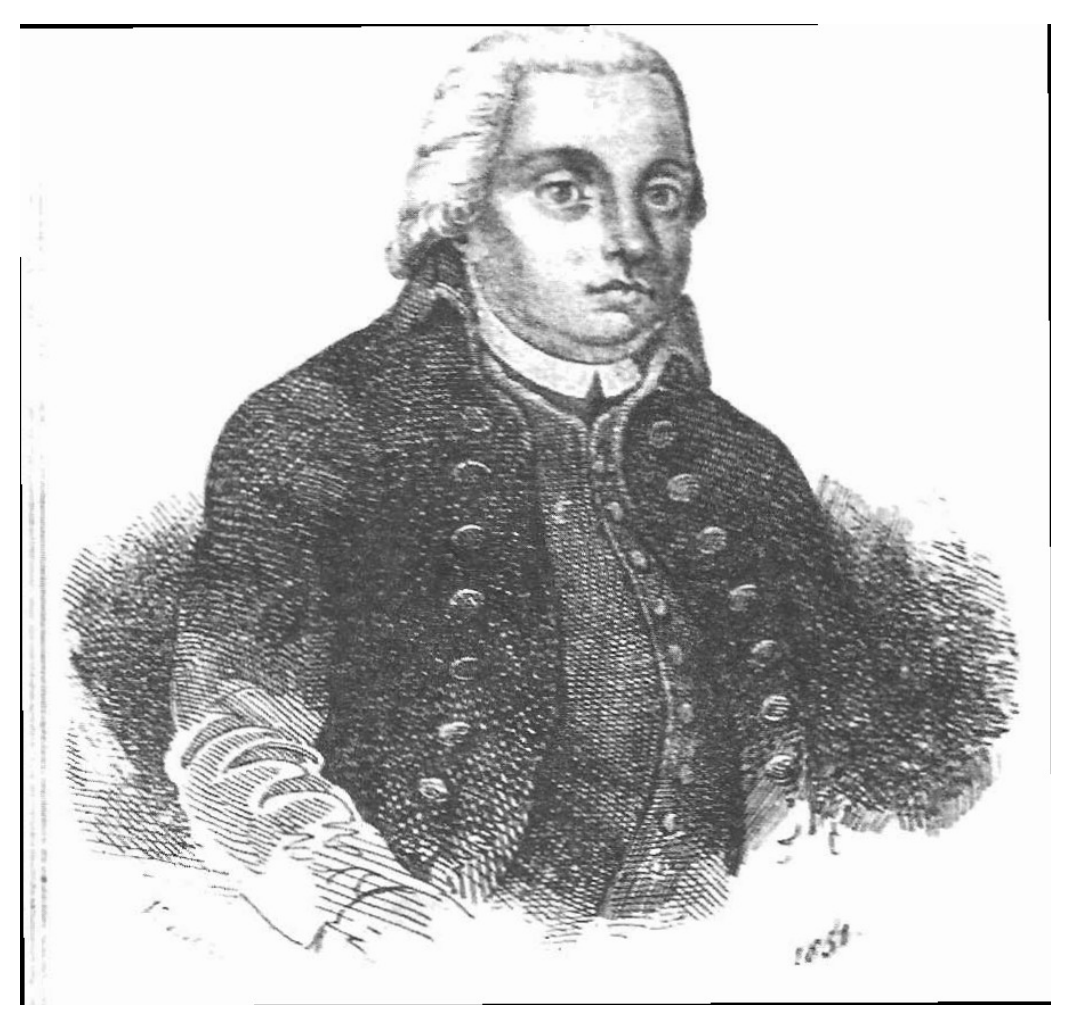

Figura 1: Domingos Caldas Barbosa - Lereno Selinuntino - Falecido em 1800

Não estaria o inglês, William Beckford, com a frase "uma combinação de sons estranhos e não desagradáveis" a descrever essa tendência à contrametricide, à síncope, presentes nas peças que compõem o manuscrito Modinhas do Brasil? Sobretudo pelas jovens estarem cantando modinhas brasileiras? Também seu mestre de canto, "um frade baixo e quadrado, de olhos verdes" que repenicava a viola, tal e qual o acompanhamento do excerto do exemplo musical acima e que persiste em toda a peça, não poderia ser Domingos Caldas Barbosa, o Lereno Selinuntino? Tudo isso é seguramente suposição; mas uma suposição altamente possível! Sobretudo, se levarmos em questão que a descrição do inglês bem combina com o retrato que conhecemos de Lereno. Outra coisa, é que época destacada pelo inglês corresponde ao período em que Domingos Caldas Barbosa se encontrava em Lisboa, onde morre e onde será enterrado.

De qualquer modo, esta tendência à síncope, presente já nos vilancicos mexicanos e denominados de negrillas pelos habitantes locais, entre os séculos XVI e XVII na obra de Gaspar Fernandes no México (TELLO, 1999), vai reaparecer nos lundus e em algumas modinhas do códice da Biblioteca da 
Ajuda, Modinhas do Brasil e de modo muito sofisticada, e com parcimônia em algumas peças do códice Muzica escolhida da Viola de Lereno, ambos, anotese, ligados de certa forma a Domingos Caldas Barbosa. Porém, como destacado acima, completamente adaptados às tendências classicizantes da música luso-brasileira de fins dos setecentos. Em suma, longe de querer efetuar um elogio à "cordialidade", este resquício de patrimonialismo negativamente destacado no antológico trabalho do saudoso Sergio Buarque de Holanda, Raízes do Brasil (2006); o lundu representou uma negociação constante, e duradoura, com as tendências que vigoravam na época, uma espécie de "liberdade relativa", como teorizada por Luiz Felipe Alencastro:

"Negros alforriados morando na solidão dos sertões poderiam - imediatamente ou nas gerações seguintes - ser considerados quilombolas e capturados por capitães-do-mato em busca de recompensa. Reputada quilombola, uma família negra isolada, composta de pai, de mãe e de três filhos corria o perigo de ser capturada, cativada e eventualmente massacrada: a criminalização da fuga de escravos se transforma numa ameaça mortal a todo núcleo autônomo de negros livres no território brasileiro. Para tais pessoas, tais famílias, a melhor garantia à preservação da liberdade consistia em aceitá-la como uma liberdade relativa, prestando servicos ao fazendeiro ou senhor de engenho que reconhecesse e garantisse seu estatuto de não escravo". (ALENCASTRO: 2000, p. 345).

Nesse aspecto, o lundu, essa espécie de cidadão de dois mundos, constitui-se no próprio resultado dessa constante negociação - não politicagem, pois deste modo ainda estaríamos no âmbito da cordialidade - e como sintetizou Serge Gruzinsky:

"As mestiçagens nunca são uma panacéia; elas expressam combates jamais ganhos e sempre recomeçados. Mas fornecem o privilégio de se pertencer a vários mundos numa só vida" (GRUZINSKY, 2001. P. 320).

É nesse sentido que entendemos que o lundu não foi completamente domado pela civilidade ilustrada: se por um lado, surgiu já de uma síntese, unindo elementos do mundo negro aqui na colônia a matrizes de danças e estruturas musicais européias; por outro lado, e mesmo vigiado nos largos das cidades e nos terreiros, como enfatizou Nery (2005), soube manter-se não totalmente domesticado, exercitando, no paralelo, suas licenças, suas chulices, mesmo com os narizes retorcidos dos moralistas; mitigando a inoculação de 
uma sociabilidade ilustrada, mantendo algo diverso que, em parte, fugiu ao controle; pelo menos numa pequenina parcela da produção musical.

\subsubsection{A moda das cantigas ou a música nos salões}

O projeto da ópera como processo civilizador ilustrado defendido por Mário Vieira de Carvalho em seus livros Pensar é morrer ou o teatro de São Carlos na mudança de sistemas sociocomunicativos desde fins do século XVIII aos nossos dias (1993) e Razão e sentimento na comunicação musical: estudo sobre a dialética do iluminismo (1999), adaptado e ampliado à realidade da colônia brasileira por Diósnio Machado Neto em Administrando a festa: música e iluminismo no Brasil colonial (2008) que destaca como a modinha, compreendida como a canção lírica no último quartel século XVIII e também o lundu, devidamente adaptado e estilizado, exerceram papel não só sociabilizador, mas também elemento emancipador, sobretudo para as mulheres, no espaço social privado e público; o que será de importância fundamental para os novos tempos que se anunciam. Nesse aspecto, não só freqüentar os teatros e saraus, mas também, o aprendizado musical formal, pelo menos para as classes mais privilegiadas, deveria fazer parte de uma educação, já calcada nos moldes ilustrados. É nesse sentido que a prática do canto por parte das moças, o tanger a viola (guitarra) ou o teclado, passa a ser um aspecto importante para a absorção desta nova sociabilidade calcada em um projeto iluminista, como destacado pelos autores citados.

E não é por outra razão, que uma profusão de peças para teclado, viola e, sobretudo, canto com acompanhamento para teclado ou guitarra ${ }^{4}$, surgirão a partir da segunda metade do século XVIII:

"Canções para a performance doméstica foram compostas e publicadas em vários países, refletindo o crescente interesse na música efetuada para amadores. Cada vez mais o acompanhamento era escrito para instrumento de tecla, embora a guitarra fosse também usada. Muitas canções eram relativamente simples, usualmente silábicas, diatônicas e estróficas, com

\footnotetext{
${ }^{4}$ Usamos aqui o termo guitarra genericamente para sugerir toda uma família de cordas dedilhadas: como a guitarra barroca (de 5 ordens), ainda usada até fins do século XVIII em toda a Europa; a viola de arame portuguesa, também de cinco ordens e descendente da guitarra barroca, conhecida em Portugal como guitarra espanhola; a guitarra de 6 ordens de fins do século XVIII; a guitarra de 6 cordas simples, conhecida em Portugal como guitarra ou vila francesa; e a guitarra inglesa, ancestral da guitarra portuguesa. Para um aprofundamento, consultar: RIBEIRO, 1789; LEITE, 1796; MORAIS, 2000; TYLER, 2002.
} 
acompanhamento simples o bastante para ser tocado pela própria cantora." (GROUT, 2006, p. 500).

Na França, serão conhecidas como romance; na Inglaterra, por ballad; na Itália, arietta ou canzoneta. Na Espanha, também na passagem do setecentos para o oitocentos, surgirá a seguidilla, uma canção já valorizando tendências locais e que será o ancestral do bolero (JEFFERY, 1976, p. 5). Na Alemanha, serão conhecidas como lied, e deviam ser "simples e expressivas" e, segundo o gosto dessa época, "as canções eram consideradas tanto melhores quanto suas melodias fossem simples de catar" (GROUT, 2006, p. 501). E nesse sentido, as 1.500 canções de Johann Friedrich Reichardt (1752-1814) sobre poemas de Johann Wolfgang von Goethe, simples e silábicas, ao goso da música folclórica, parecem retratar nitidamente essa coqueluche (Ibidem, $p$. 501). Mozart (MOZART, 1992) e Haydn (HAYDN, 1960) podem ser incluídos entre aqueles que efetuaram canções para uso doméstico, consequentemente, adaptando o estilo clássico vienense às cações mais simples, estróficas e silábicas. Haydn, além de canções em alemão, efetuou também canções em inglês (ballads), incorporando as características da música popular inglesa da época (Ibidem, 1960). No mundo afro-luso-brasileiro, essas "singelas" canções foram denominadas genericamente de modinhas num primeiro momento; e lundu, assim que reconhecida a autonomia da canção com elementos tanto poéticos quanto musicais afro-brasileiros, como vimos discutindo acima.

$\mathrm{Na}$ Espanha, como antecipamos anteriormente, o exímio guitarristas Fernando Sor (1778-1839) que, além de vasta produção para o violão, como divertimentos, fantasias, sonatas, valsas, métodos para violão, um método para canto ainda não localizado e um balé; compôs onze jogos contendo Three Italian Ariets para uma voz, dois jogos contendo Three Italian Ariets para duas vozes e um jogo, Three Canons, para duas e três vozes, publicados em Londres (JEFFERY, 2002: vii) por ocasião de seu exílio no período da invasão napoleônica na Espanha. Escritas em estilo italiano e influenciadas, obviamente, pela ópera, o grande modelo musical vigente, as peças articulam todas as conquistas do estilo clássico: como a busca de equilíbrio simétrico, esteja disposta numa forma binária ou ternária; frases periódicas e articuladas e gosto pelos ornamentos leves e passagens rápidas, exigindo do intérprete uma voz leve e ágil, padrão ainda clássico (PACHECO, 2008). 
A seguidilla, "um tipo de poema, o qual pode ser transformado em música" (JEFFERY, 1976, p.5) está ligado à origem do bolero espanhol, dançado sobre as seguidillas manchegas, com movimentos mais velozes que estas, as murcianas e também as sevillanas, com movimentos tão rápidos, que parece que os dançarinos estavam a voar; e por isso o termo "bolero", que em sua origem descende da palavra volare (voar). A dança logo se popularizou, sendo apresentada nos teatros, como entremez e ao desenvolver movimentos mais erotizados, caiu de moda (Ibidem, 1976: 6). Sua canção é estrófica e, em sua grande maioria, silábica, com pequenos melismas e fiorituras, aliando características da música popular espanhola da época (em compasso ternário, uso copioso de tercinas), com frases muitas vezes assimétricas, porém articuladas e acompanhamento leve, disposto em arpejos ou acordes rebatidos.

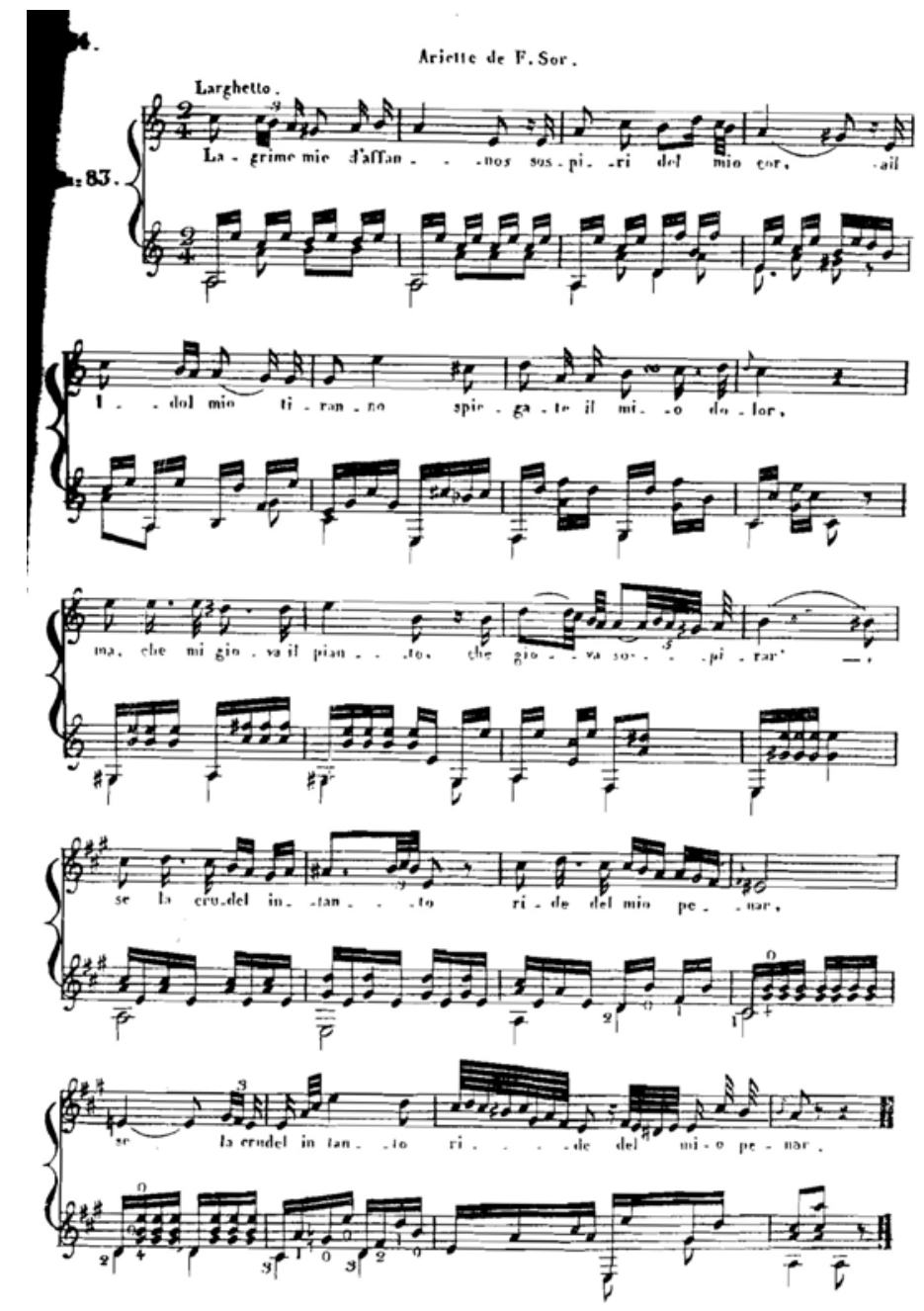

: Lagrime mie d'affanos - Ariette - Fernando Sor 


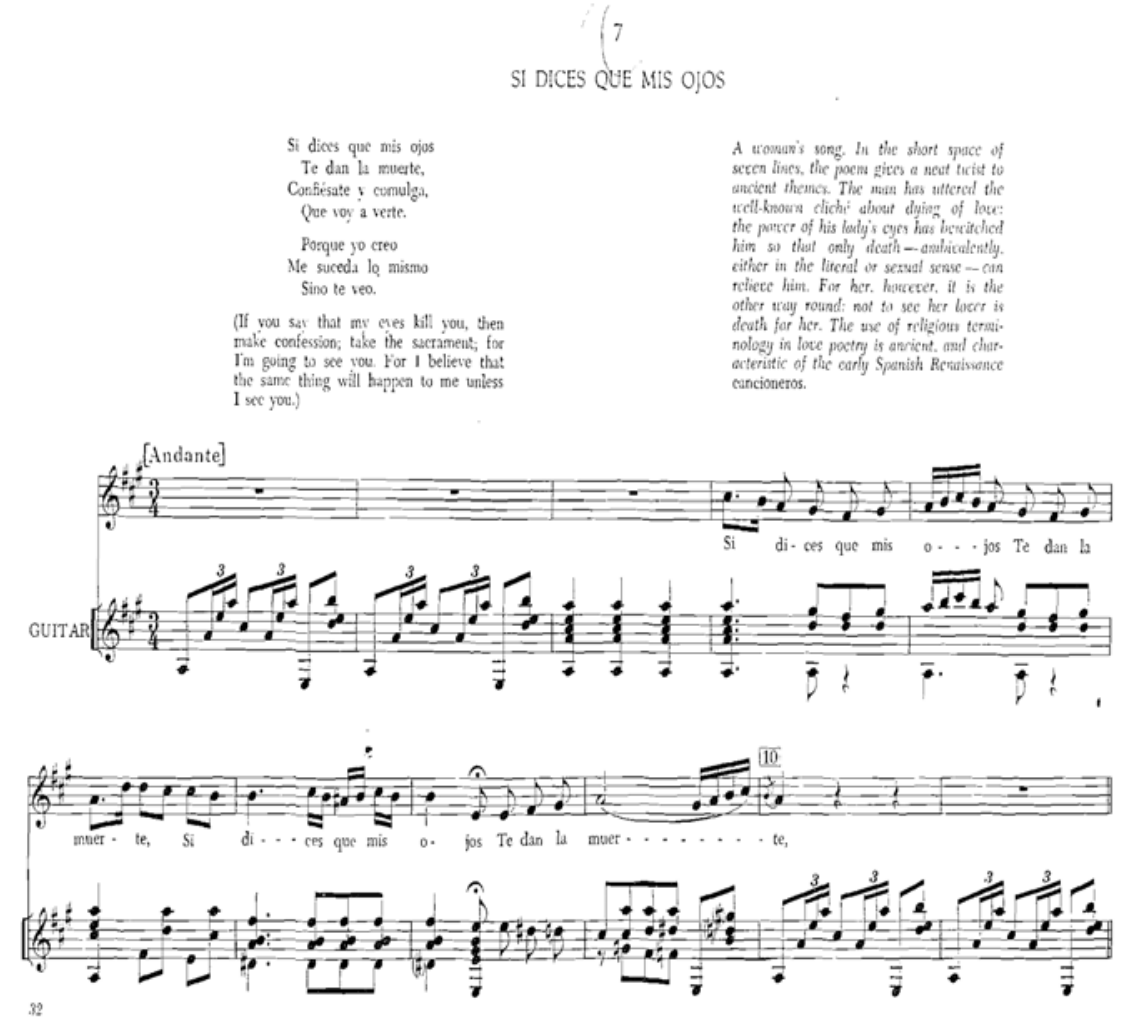

Se dices que mis ojos (trecho) - Seguidilla - Fernando Sor

Na Itália, Mauro Giulianni (1781-1829), também virtuose da guitarra, escreveu vários ciclos para voz e violão. Em italiano compôs os ciclos Sei Ariette (GIULIANI, 1987) com acompanhamento opcional de violão ou piano, e Sei Cavatine per voce e chitarra (GIULIANI, 1984). Além disso, compôs um ciclo de Romances (GIULIANI, 1983) em francês e um em alemão, Sechs Lieder (GIULIANI, 1976). Acompanhando essa tendência, as Sei canzonette italiane coll'Accompagmamento di Chitatarra composte dal Signor D. Cimarosa, Vienna, presso Gio. Cappi, apresenta

"Il genre dell'aria o della canzonetta [que] trova nella voce e nella chitarra i protagonisti ideali e indiscussi di piacevoli serate transcorse nei salotti fin dalla seconda metà del '700” (CIMAROSA, 1985).

A produção de modinhas e lundus será desenvolvida justamente nos últimos vinte anos do século XVIII. Nessa época que serão publicados: o Jornal de Modinhas entre os nos de 1792-1796; o códice Modinhas do Brasil (LIMA, 2010) datado do último decênio deste século; o códice Muzia escolhida da 
Viola de Lereno, de 1799; e o códice, Jornal de modinhas novas para as moças, data de 1801. Vários manuscritos avulsos tais como: Hei de amar, do tenor Giuseppe Forlivese, fl. 1794 (www.bn.pt/purl); a coletânea de Duettini, Cavatina, e canzoncina Portoghesa a due soprani e solo (www.bn.pt/purl) do contralto e compositor (MORAIS, 2000: 77) Giuseppe Totti (17... -1832); a coleção de Modinhas com acompanhamento de Piano Forte ou guitarra, de Domingos Schiopetta, 1788-1835 (www.bn.pt/purl). A coleção de Joaquim Manoel da Câmara, 20 modinhas portuguesas (CRUZ, 2000) copiadas e harmonizadas por Sigismond Neukomm, hoje localizadas em Paris e na Inglaterra (FAGERLANDE, 2008), data do período de sua estada no Brasil entre os anos de 1816 e 1821.

A Nova arte de viola que ensina a tocalla com fundamneto sem mestre, de Manoel da Paixão Ribeiro (1789) e Estudo de guitarra, em que se expõem o meio mais fácil para aprender a tocar este instrumento, de Antonio da Silva Leite (1796), apesar de não serem dedicados diretamente às modinhas, tem como proposta o ensino às pessoas interessadas: o primeiro, dedicado a viola de arame de cinco ordens, uma espécie de variação da guitarra barroca e encordoada com cordas de metal, além de todo ensinamento prático-teórico necessário (notação e leitura musical, posição das mãos, dedilhados, acompanhamento, entre outras coisas), traz no final algumas peças para violino com acompanhamento de viola, e duas modinhas de seu mestre, José Maurício (o de Coimbra) a duas vozes e acompanhamento desse instrumento.

O Estudo de guitarra de Silva Leite, dedicado à guitarra inglesa ou portuguesa, como será conhecida posteriormente, traz lições bastante completas, divididas em duas parte: na primeira, contém "as principais regras da música" e na segunda "as da guitarra". Ao final apresenta uma coleção "de alguns minuetes, marchas, contradanças, e outras peças mais usuaes, com accompanhamento de segunda guitarra" (sic). Portanto, esses dois tratados serão de suma importância para a educação musical das classes médias emergentes da época, atendendo uma demanda social absolutamente ligada a tendências da sociabilidade ilustrada, como vimos defendendo acima.

Portanto, a canção de amor do mundo afro-luso-brasileiro de fins do século XVIII e início do XIX, está inserida dentro desse projeto: o desenvolvimento de uma sociabilidade ilustrada, ou seja, secular e racionalista, 
por via dos modelos comunicacionais musicais tais como a ópera, a dança, a canção de salão, peças instrumentais para entretenimento nos saraus e entremezes, como discutidos por Viera de Carvalho (1999) e Machado Neto (2008) e coordenado tanto por intelectuais como pela burguesia em ascensão nos séculos das luzes: esta burguesia que dará rumo ao capitalismo moderno por um lado; e base para o questionamento do ancien regime por outro (WALLERSETIN, 2006). No entanto, ao ser adaptada aos trópicos e ajustadas à realidade brasileira, teve que negociar com a sociedade local, e nesse sentido, o lundu apresenta-se como um produto já da adaptação dessa realidade: não como símbolo de um nacionalismo purista, preocupado com mitos fundacionais; mas como insígnia de uma liberdade relativa como a nomeou Alencastro (2000), uma possível identidade de resistência, segundo Manuel Castells (1999), e uma negociação constante, diária e sem descanso. Em última análise, uma espécie de ilustração do "B".

\section{2. $O$ canto e a Lira}

\subsubsection{Música e poesia}

A relação entre poesia e canto parece remontar a tempos imemoriais! Tanto a declamação lírica na Antiguidade Clássica (MOISÉS, 2003:), quanto os relatos bíblicos dos cantos de Salomão; assim como a tradição que chega aos trovadores, uma das pontes entre Oriente e Ocidente, cantar e acompanhar-se, parece ser uma busca constante de expressividade humana na cultura do ocidente e, sobretudo, será aquela que se ligará, mesmo que muito mais tarde evidentemente, a uma tradição que aportará neste lado do Atlântico. Também na tradição popular oral, até onde nossos ouvidos podem alcançar, o canto, seja para o trabalho, nas horas de lazer ou para abrandar o sofrimento, foi uma constante em diversas culturas, e neste caso, não só na ocidental.

$\mathrm{Na}$ Idade Média, isso para mantermos essa pequena digressão dentro dos limites geográficos do ocidente, já no século XI, trovar era sinônimo de compor (poesia) e cantar (CANDÉ, 1994), atestando, portanto, a indissociabilidade destas artes: poesia e música. E terá sido justamente com os trovadores que aprendemos a cantar nossos poemas, mas sobre tudo, como 
deveríamos amar. De qualquer modo, os trovadores na Idade Média eram, na grande maioria dos casos, nobres com boa formação humanística e que declamavam poemas e tocavam instrumento por puro diletantismo: a cortesia, ou a arte de cantar a beleza do mundo (CULLIN, 2002, p. 49). Não pretendemos, de modo algum, reconstruir o sentido da canção, mas apenas observar a importância da ligação entre poesia e música para a história da música ocidental; e como esta busca será uma constante conservando-se nos séculos que se seguem.

Outro fato importante a ser destacado é que a poesia lida desde os tempos de antanho, com problemas absolutamente caros à música. A questão métrica e rítmica, a sonoridade e a melodia das frases, são apenas alguns pontos em que poesia e canto se tocam. Portanto, era compreensível que esses conceitos transitassem entre as duas esferas; e quase uma profecia que esses dois pólos da expressividade humana, hoje considerados mundos disciplinarmente separados, caminhassem lado a lado e, muitas vezes, com mãos delicadamente atadas.

De qualquer modo, toda uma teoria que passou a potencializar a melodia principal em fins do século XVI, e o advento da melodia acompanhada, deu um novo impulso para esta relação. Não queremos com nossa afirmação desmerecer a tradição da chanson francesa, da frottola e do madrigal na Itália e a importância que estes gêneros darão à voz mais aguda tratada como voz principal (GROUT, 2006); tampouco pretendemos preterir a música instrumental dos séculos XV e XVI que já carregavam o germe da melodia acompanhada (BUKOFZER, 2002, p. 29). Mas, ao contrário, enfatizar a dimensão que esta relação, palavra e canto tomaram a partir do século XVII em diante, proximidade que deve ser considerada com bons olhos.

A Camerata Fiorentina do conde Bardi, foi seguramente um lugar privilegiado para a futura relação entre música e texto. Esta relação entre palavra e música, como afirmado acima, há muito tempo tem sido objeto de discussões musicais, seja no campo da estética ou num campo puramente teórico. Porém, as discussões da Camerata abrem perspectivas que irão nortear essa relação e conceber os rumos da música em uma perspectiva diferenciada. A idéia de Cláudio Monteverdi, "la letra es la maestra de la 
armonia" (BUKOFZER, 2002, p. 20) ${ }^{5}$, traduz com muita propriedade essa relação. $\mathrm{E}$ se tal não foi propriamente uma mudança, pois os músicos sempre tiveram que lidar com os textos, foi uma ênfase bastante acentuada em direção à palavra, ou melhor, em direção ao sentido do texto, e como este deveria se relacionar com a música. Sentido não só relacionado às sensações, mas também e, sobretudo, às emoções humanas, ou como se diria no século XVII, aos afetos ou paixões da alma (DESCARTES, 1979[1649]).

Contudo, não queremos com nossas observações, de modo algum, diminuir a importância do mundo da música, sua história, suas sofisticadas conquistas teóricas ao longo dos séculos. Mas temos consciência do quanto a notação musical da Idade Média deve à poesia no que tange às teorias métricas e melódicas advindas da recitação, e como estas foram aproveitadas para dar um novo impulso à notação musical dos séculos XI e XII, ou seja, a relação entre longa e breve advinda "dès six pieds de la métrique classique" (CULLIN, 2002, p. 115) $)^{6}$.

Retornando, porém, às transformações ocorridas no inicio do Período Barroco, a melodia acompanhada, o baixo contínuo e o estilo recitativo, representaram uma das maiores liberdades no que tange ao "recitar cantando" (CACCINI, 1978[1614]; 1982[1602]). Pensamos, então, que a história da canção como a entendemos hoje, deve, e muito, a esta mudança de paradigma: da polifonia à melodia acompanhada. De qualquer modo, a "irrecusável busca de sentido" (MARTON, 2004) sempre foi uma constante na história da cultura ocidental, e com a música não podia ser diferente. E quanto à música instrumental, um ente "quase" abstrato aos ouvidos não especializados, quando associada ao texto, acaba buscando neste um porto seguro para expressar sentidos.

É evidente que a música construiu ao longo dos séculos a sua trajetória e se orientou, com ou sem palavras, na busca de uma linguagem própria. A linguagem musical, entendida como a busca de organização não somente estrutural: como organizar a disposição rítmica, melódica e harmônica em sua micro e macro forma; mas também semântica: ou seja, como esta busca foi resolvida em sua conjuntura histórica, quais os elementos autônomos ou

\footnotetext{
5 "O texto e o mestre da harmonia" (T.A.)

6 "Os seis pés da métrica clássica" (T.A.)
} 
heterônomos que concorrem em cada época e qual será o significado dessa música para a sociedade em questão.

Tampouco queremos sugerir que a música instrumental deixou de construir sua própria linguagem: a música se expressa também pela sua microforma, além de sua macro-forma: pequenos motivos ritmos e melódicos nos "afetam" e nos remetem a estruturas mais extensas e complexas; combinações harmônicas, mais ou menos convencionais, sugerem suas relações, e nos guiam ou nos frustram ao serem encadeados estruturalmente e em sua disposição temporal. O silêncio que conquistou cada vez mais "espaço" na estrutura musical; não atua somente como pontuação, mas também expressivamente; diversos tipos de acentos, articulações e timbres sonoros nos remetem a espécies de sotaques idiomáticos... Dizendo de outro modo, a música, entendida como arte dos sons, constrói sua história interna. E como toda disciplina específica, ora dialoga mais de perto com seus pares, ora busca maior autonomia em sua autoconstrução.

Insistindo ainda no século XVI, época de ouro da polifonia, este será decisivo na afirmação de gêneros vocais que mais tarde passarão a ser considerados verdadeiras identidades nacionais. Estamos aqui a falar do ayre inglês, da chanson francesa, da frottola e do madrigal na Itália e, sobretudo, dos romances e villancicos ibéricos. Isso para nos atermos ao mais difundidos. Estes dois últimos, diga-se de passagem, irão compor a identidade sonora tanto de Portugal quanto da Espanha, mesmo que forçosamente irmanados pelos longos sessenta anos da União Ibérica, se assumirmos, evidentemente, a perspectiva lusitana. Mas o que carece ser destacado é que todos esses gêneros nascem ainda dentro da tradição polifônica e vão aos poucos absorvendo a linguagem tonal e se modificando gradativamente no contexto dessa nova realidade.

Mas retornando ao centro de nossa discussão, o advento da melodia acompanhada associada ao desenvolvimento da tonalidade, alterou, no início de modo gradativo e posteriormente de modo mais enfático, os parâmetros da canção, tanto em seu modo de fazer quanto em sua escuta, evidentemente. É exatamente no contexto da tradição tonal que surgirão os gêneros que se tornarão fundamentais, no ocidente, para a moderna canção. E Portugal, mesmo adotando tardiamente as conquistas do estilo barroco e já caminhando 
para sua fase galante (não tardarão os primeiros entremezes de Giovanni Bapttista Pergolesi, as sonatas de Domenico Scarlatti com seus motivos contrastantes, por exemplo), adentra esse novo estilo em uma espécie de apogeu. Não nos esqueçamos que o grande mestre dos mestres portugueses da primeira metade do século XVIII foi Domenico Scarlatti e que os primeiros bolsistas portugueses em Itália vão se especializar em Roma; e uma segunda leva, em Nápoles (NERY,1989:). Portanto, o início do século XVIII inaugurará, sem sombra de dúvidas, uma nova fase para a música portuguesa. É justamente desta fase a inauguração da Escola de Música da Patriarcal, escola recém criada com o intuito de propiciar formação musical aos jovens talentos desse novo porvenir e que terá Scarlatti como figura principal no modelo de sua implantação (NERY e CASTRO1989, p. 88).

\subsubsection{Cultura burguesa, simplicidade e laser}

A modinha e o lundu luso-brasileiros, elaborados a partir da segunda metade do século XVIII, serão a descendência direta das complexas transformações ocorridas na cultura musical portuguesa durante este século. Tais transformações estão absolutamente imbricadas, sem dúvida, no panorama social, político e cultural da época: se Portugal continua monarquista ainda por muito tempo, uma cultura burguesa, mesmo que timidamente iluminista, vai ganhar os palcos dos diversos teatros lusitanos, os salões privados das classes altas e médias, e instalar-se também no cotidiano (VIEIRA DE CARVALHO, 1993; NETO, 2008).

Embora os concertos públicos lusitanos se iniciem mais tardiamente em relação a outros países como Inglaterra, França e Alemanha (GROUT, 2006, p. 476), por exemplo, a inauguração de teatros dedicados à ópera reflete uma mudança de comportamento no que diz respeito ao laser do futuro cidadão burguês e das classes menos favorecidas que começa a participar mais ativamente da vida social, econômica, política e, portanto, cultural, pelo menos nos centros urbanos setecentistas, sobretudo em Lisboa (VIEIRA DE CARVALHO, 1993).

A modinha e o lundu, como afirmado acima, irão se estabilizar como gêneros musicais após 1750, e absorverão as transformações ocorridas em 
Lisboa e não sem adaptações, é claro, em uma fase em que impera a expressividade rococó-clássica (DUPRAT, 1990). No último quartel do século XVIII, esses dois gêneros, dominarão cada vez mais o cenário social da época com sua presença nos salões, saraus e posteriormente os entremezes teatrais. É nessa época em que a arte como um todo, e a música em nosso caso específico, vai se distanciando do modelo barroco, ainda presa aos aspectos ético-pedagógicos e ao convencionalismo do afeto, e buscará no ideal da simplicidade e sensibilidade um porto seguro para sua expressividade: "A 'emoção', o movimento anímico e sensível, era o efeito que o sentimentalismo do século XVIII esperava da música" (DAHLHAUS, 2003. p. 29).

É nesse aspecto que a música italiana, a preferida de Rousseau, a "Che parla più vicino al cuore" (FUBINI, 1995: 94) e que "representa solamente um diletto per i nostri sensi, per l'udito, accarezzato dal gioco dei suoni e dalle dolci melodie" (FUBINI, 1995, pp. 89/90) ${ }^{7}$, torna-se o novo padrão não só de composição como da recepção (VIEIRA DE CARVALHO, 1999:). É também neste sentido que os compositores de modinha, já tendo absorvido estas influências, buscam comprometer-se com os sentimentos contidos nos textos poéticos: "não a sua pessoa privada e empírica, mas o seu 'eu inteligível', o análogo ao 'ele lírico' da poesia” (DAHLHAUS, 2003 :36), em consonância "com la nuova estética della piacevolezza e della linearità melódica” (FUBINI, 1995. P. 97) ${ }^{8}$. E é justamente nesse sentido que

“L'austero ideale bachiano di una musica che 'a null'altro deve mirare che all'onore di Dio e alla recreazione dell'anima', non è conciliabile né mediabile con la nuova estética della piacevolezza e della linearità melodica", ${ }^{9}$ (FUBINI, 1995, p. 97).

\subsubsection{Melodia, sentimento e natureza}

Se nos ativermos à categorização proposta por Mário Vieira de Carvalho em seu livro Razão e sentimento na comunicação musical (1999), o Renascimento marca uma das principais mudanças no que tange à

\footnotetext{
7 "representa somente um deleite para o nosso sentido, para o nosso ouvido, acariciado pelo jogo dos sons e de doces melodias" (T.A.).

8 "com a nova estética do prazer e da linearidade melódica" (T.A.)

9 "O austero ideal bachiano de uma música que 'a nenhum outro deve considerar do que a honra de Deus e a recreação da alma', não é conciliável nem adaptável à nova estética do prazer e da linearidade melódica" (T.A.) .
} 
expressividade musical; o segundo momento seria o que veio a ser conhecido como "o novo estilo sensível" ou Empfindsamkeit, que acreditamos estar mais em sintonia com a produção da modinha e do lundu; e um terceiro momento, 0 expressionismo musical da virada do século XIX para o XX (VIERIA DE CARVALHO, 1999, pp. 29-33).

Evidentemente que esta mudança para uma estética do sentimento ou sensibilidade (Empfindsamer Still), não incide apenas em questões musicais, mas na arte como um todo. E concordando com Terry EAGLETON (1993), trata-se de uma mudança profunda que afetará os rumos da arte, sobretudo por colocar certas áreas "obscuras" do ser humano no foco das discussões científicas e filosóficas: "Com o nascimento da estética, a esfera da arte começa também a sofrer algo de abstração e formalização características da teoria moderna em geral." (EAGLETON, 1993, p. 8). E não somente isto, pois para ele, essa "ciência da sensibilidade" coloca no centro "tudo o que pertence à vida somática e sensual" (Ibidem, p. 17), suas conseqüências, seus controles e descontroles, pois

"O mundo dos sentimentos e das sensações não pode ser ignorado como 'subjetivo' (...) precisa ser trazido para dentro do escopo majestoso da razão." (Ibidem, p.18)

De qualquer modo, não obstante os rumos que o pensamento iluminista tomará nos próximos anos e como se afirmará como força política hegemônica nos século vindouros ${ }^{10}$, importa-nos verificar como o conceito de simplicidade, verdade, sensibilidade, virtude e acessibilidade, aliados ao conceito de natureza, nortearam toda uma mudança no fazer e na recepção musical durante o século XVIII (Ibidem, pp. 73-119). E é justamente essa mudança de concepção no que tange a questão poético-musical que, a nosso ver, norteará tanto a poesia quanto a musicalidade relacionada também à modinha e ao lundu.

Num primeiro aspecto, "o 'simples' oposto ao difícil, o 'simples' como sinônimo de belo e atributo de uma arte que imita a natureza" (Ibidem, p. 73)

\footnotetext{
${ }^{10}$ Para uma discussão mais profunda, ver EAGLETON, T. A ideologia da estética. Rio de Janeiro: J.Z.E: 1993; VIEIRA DE CARVALHO, M. Razão e sentimento na comunicação musica. Lisboa: Antropos, 1999, cap. Ópera seria e processo civilizacional; VIEIRA DE CARVALHO, M. "Pensar é morrer" ou O teatro de São Carlos na mudança de sistemassócio-comunicativos desde fins do século XVIII aos nossos dias. Lisboa: Imprensa Nacional, 1993.
} 
passa a ser um dos principais fundamentos da arte e, por consequência, do fazer musical no decorrer do século XVIII. No sentido exposto acima, a natureza é o local das coisas simples; e o simples, é aquilo que se manifesta de modo direto, sem rodeios e ao alcance de todos, portanto acessível. E é deste modo que deve manifestar-se a poesia e, sobretudo a música (ou a melodia): se na poesia dessa época, o natural é discurso direto, com ritmos simples, a fuga do gongorismo (ausência de figuras de linguagem, de frases em ordens inversas), a tematização da natureza no sentido bucólico, a presença do camponês (pastor), a tematização do amor sereno, ideal (BOSI, 1994); na música, a grande finalidade era a busca do "canto simples", entendido como sinônimo do natural e, consequentemente, do verdadeiro (VIEIRA DE CARVALHO, 1999, p. 73 e 81). É nesse aspecto que para Rousseau a melodia é "il linguaggio (...) che parla più vicino al cuore" (FUBINI, 1995: 94); e o canto e a poesia que "hanno uma mítica origine comune (...) insieme realizzavano la più autentica forma de expressione"12 (FUBINI, 1995: 94). E mais adiante, ainda seguindo o raciocínio de Rosseaou: "L'armonia non imita la natura: quest'última 'ispira canti e non accordi" "13, (FUBINI, 1995: 95), este, o canto, torna-se "a voz da natureza" (DU BO, apud VIEIRA DE CARVALHO, 1999, p. 94), do sentimento...

É nesse sentido que entendemos a melodia no século XVIII, não somente como parte de uma estrutura hierárquica no discurso musical da época, mas como o veículo próprio, privilegiado, do sentimento e da expressividade musical que "fala" direto ao "coração". Este, entendido não como o órgão vital da perfeita máquina humana ainda num sentido mecanicista; mas como o elo instintivo entre a expressão contida na melodia e sua recepção por parte do ouvinte. É ainda nesse sentido que no século XVIII poder-se-á eleger a “música como linguagem do coração” (Ibidem, p. 97).

\subsubsection{Poesia e música}

\footnotetext{
11 "A linguagem (...) que falar mais próxima ao coração" (T.A.).

12 "têm um origem mítica comum (...) juntas realizam a mais autência forma de expressão" (T.A.).

13 "A harmonia não imita a natureza: é está última que 'inspira cantos e não acordes" (T.A.).
} 
A busca pela simetria e formalismo aliados a uma concepção de simplicidade e natureza advindo do ideal iluminista invadirá todos os âmbitos da arte, e com a poesia não será diferente: "A atividade do espírito obedece, portanto, a uma lei geral, que é a própria razão do universo, e não se destaca da natureza". Ou ainda: "Deístas, céticos, ateus; materialistas, empiristas, sensualistas - todos sentiam profundamente essa presença da lei natural, no homem e no universo" (CANDIDO, 1964, p. 61).

A temática bucólica aliada a uma simplicidade advinda de uma idealização da natureza como acenado acima, tornar-se-á uma das buscas dessa nova sensibilidade (BOSI, 1994, p. 57). Nos escritos dessa época, além da procura de equilíbrio formal (também um aspecto da natureza para os iluministas), a opção pela simplicidade efetuada nos ritmos fluentes e a minimização do uso de metáforas, espécie de anti-gongorismo, serão características imprescindíveis do poema árcade. Como exemplo, veja-se a Lira V Parte I:

Acaso são estes

Os sítios formosos,

Aonde passava

Os anos gostosos?

São estes os prados,

Aonde brincava

Enquanto pastava,

O gordo rebanho,

Que Alceu me deixou?

São estes os sítios?

São estes; mas eu

O mesmo não sou.

Marília tu chamas?

Espera, que eu vou.

Como destacou Mário Faustino nas crônicas publicadas no Jornal do Brasil entre os anos de 1956 a 1959, a "A poesia de Gonzaga é para ser cantada" e "Toda sua poesia é extremamente cantabill" (FAUSTINO, 2003, p. 121). Não é sem razão que estes versos, como tantos outros das liras de Dirceu, foram transformados em música, pois a fluência rítmica aliada à melodia sugerida pelo verso é, seguramente, um convite à modinha. Em outro poema, desta vez a Lira IV, Parte II: 
Já, já me vai, Marília, branquejando Louro cabelo, que circula a testa, Este mesmo, que alveja, vai caindo E pouco me resta.

A singeleza dos versos, aliados ao discurso direto e sem metáforas, o ritmo fluente, sugerem, como tão bem assinalou Faustino (2003), uma melodia simples, fluente que the faça justiça. Assim que entendemos a sofisticada simplificação buscada na atmosfera campestre que tanto os poetas árcades perseguiram e foram expressas em singelas canções que, no mundo lusobrasileiro de fins do século XVIII, passam a ser denominadas modinhas. E mesmo esse diminutivo, advindo do substantivo moda, tem muito a dizer, pois, pequeninas, delicadas, graciosas...

Evidente que há muitos outros poemas que não foram transformadas em canções. Porém, as sugestões musicais nas liras de Tomás Antonio Gonzaga, são copiosas. Como por exemplo, no segundo quarteto da estrofe dois da Lira I, Parte I

Eu vi o meu semblante numa fonte, Dos anos ainda não está cortado:

Os Pastores, que habitam este monte, Respeitam o poder do meu cajado:

Com destreza toco a sanfoninha, Que inveja me tem o próprio Alceste:

Ao som dela concerto a voz celeste;

Nem canto letra que não seja minha.

Graças, Marília bela, Graças à minha Estrela!

E na Lira XI, Parte I, na primeira estrofe, encontramos os seguintes versos:

Não toques, minha Musa, não, não toques Na sonora Lira,

Que às almas, como a minha, namoradas

Doces canções inspira:

Assopra no clarim, que apenas soa,

Enche de assombro a terra!

Naquele, a cujo som cantou Homero, Cantou Virgilio a Guerra. 
Em outra, na Lira XXIII, Parte I, nas estrofes três, quatro e cinco:

\author{
Em tom de graça \\ Ao terno amante \\ Manda Marília \\ Que toque, e cante. \\ Pega na lira, \\ Sem que a tempere, \\ A voz levanta, \\ $E$ às cordas fere. \\ C'os doce pontos \\ A mão atina, \\ E a voz iguala \\ À voz divina.
}

Além de instrumentos ligados ao mundo pastoral, como a lira e o clarim, há a sugestão de que almas apaixonadas inspiram "Doces canções". Além disso, a presença de Homero e Virgílio atesta o compromisso desses poetas ilustrados com a tradição clássica antiga que a nosso ver não é somente um compromisso com a erudição, mas com simetria e equilíbrio formais advindos dessa tradição e sua consumação numa poesia "doce e singela", ao alcance de todos e não só uma poesia hermética, efetuada para iniciados. Nesse aspecto, ousamos perguntar: será que Dirceu improvisava singelas melodias? Será que Marília cantava com voz doce e natural? Não temos informações a este respeito e não é nosso intento defender tal tese. Porém, nada disto seria impossível! Além disso, a sugestão de que os homens devam ser reeducados pelo poder do canto, ou seja, não só pela razão, mas também pela sensibilidade soa absolutamente Empfindsamkeit!

Na Lira VII, Parte II, Gonzaga compara o canto de Glauceste, o árcade Claudio Manoel da Costa, com o canto de Orfeu. Neste poema, não há mais aquele clima otimista e leve da poesia pastoril, mas transparece um pathos pessimista, um tanto pesado:

Meu prezado Glauceste, Se fazes o conceito, Que, bem que réu, abrigo

A cândida virtude no meu peito; Se julgas, digo, que mereço ainda 
Da tua mão socorro

Ah! Vem dar-mo agora,

Agora sim que morro.

Não quero, que montado

No Pégaso fogoso,

Venhas com dura lança

Ao monstro infame trespassar raivoso.

Deixa que viva a pérfida calúnia,

E forje o meu tormento:

Com menos, meu Glauceste,

Com menos me contento.

Toma a lira dourada,

E toca um pouco nela:

Levanta a voz celeste

Em parte que te escute a minha Bela;

Enche todo o contorno de alegria;

Não sofras, que o desgosto

Afogue em pranto amargo

O seu divino rosto.

Eu sei, eu sei, Glauceste,

Que um bom cantor havia,

Que os brutos amansava;

Que os troncos, e os penedos atraía.

De outro destro Cantor também afirma

A sábia antiguidade,

Que as muralhas erguera

De uma grande Cidade.

Orfeu as cordas fere;

O som delgado, e terno

Ao Rei Plutão abranda,

E o deixa que penetre o fundo Averno.

Ah! tu a nenhum cedes, meu Glauceste,

Na lira, e mais no canto;

Podes fazer prodígios,

Obrar ou mais, ou tanto.

Levanta, pois as vozes:

Que mais, que mais esperas?

Consola um peito aflito;

Que é menos ainda, que domar feras.

Com isto me dará no meu tormento

Um doce lenitivo;

Que enquanto a Bela vive,

Também, Glauceste, vivo. 
Nesta lira, ao utilizar versos de seis e dez sílabas, hexassílabos e decassílabos, justamente no centro da estrofe, além do efeito visual de uma frase longa, pesada, quebrando o ritmo curto das sextilhas, a recitação mais alongada dos versos decassílabos, aliados ao teor pessimista - Dirceu parece aceitar o fado, parece perceber nos rumos da inconfidência coisas muito negativas - deixa antever o peso de seu desterro e, obviamente, a saudade e sofrimentos que serão causados pelo distanciamento de sua terra, de sua Marília!

Outro poeta que teve seus versos bastante utilizados em canções da época foi Domingos Caldas Barbosa. E é em torno deste personagem que se tem desenvolvido uma grande polêmica sobre se era apenas poeta, ou se poeta, cantor e compositor de modinhas e lundus ${ }^{14}$. Nascido de mãe humilde, negra, Antonia de Jesus e de pai funcionário de dom João $V$, Antonio de Caldas Barbosa, freqüentou colégio jesuítico, onde com certeza, veio a aprender a ler e escrever e antecipar seu futuro, ainda incerto na época é claro, de clérigo em Lisboa (TINHORÃO, 2004, p. 29). Pertenceu à Arcádia de Roma e fundou, mais tarde, a Nova Arcádia ou Academia de Belas Letras (Ibidem, p. 66). Antes, porém de ir a Portugal tentar a sorte, foi soldado na Colônia do Sacramento (Ibidem, p. 37). Chega a Portugal em 1763 e candidata-se ao "curso de leis e cânones da Universidade de Coimbra" (Ibidem, p. 41) sem, no entanto frequentá-la. Mais tarde, após dificuldades com a saúde e profissionais, tornase protegido dos irmãos Vasconcelos e Sousa (Ibidem, p. 44). Finalmente, torna-se clérigo secular (Ibidem, p. 59). Teve, portanto, uma vida rica em experiências e conviveu com as várias camadas sócio-culturais tanto na colônia brasileira quanto em Portugal, o que deve, sem sombra de dúvidas, ter contribuído em sua formação, diga-se de passagem, bastante eclética.

Porém, o que nos interessa, sobretudo, é que vários de seus poemas foram transformados em música, modinhas e lundus, não só pelas mãos de renomados compositores contemporâneos seus, como Marcos Portugal, Antonio da Silva Leite; mas também restaram poemas de sua lavra com música, mas sem autoria. Aí, justamente aí, instaura-se a polêmica se também

\footnotetext{
${ }^{14}$ Para um aprofundamento dessa discussão, ver: BEHAGUE, G. Two collection... (1968); o estudo introdutório em: BORBOSA, D. C. Muzica escolhida da Viola de Lereno. Portugal: Estar, 2003; também: TINHORÃO, J. R. Domingos Caldas Barbosa: o poeta da viola, da modinha e do lundu. São Paulo: Ed. 34, 2004.
} 
compôs música além dos poemas. De qualquer modo seu nome está ligado tanto à história da literatura quanto da música. E neste aspecto, adentra sem sombra de dúvidas a história da modinha e do lundu luso-brasileiros, seja como poeta, seja como músico.

É evidente que a forma preferida de Caldas Barbosa será a quadra em redondilha maior e menor com rima entre o segundo e quarto verso, portanto, dentro de um gosto absolutamente popular. Estrofes com versos de quatro sílabas, como o poema Teu Juramento (BARBOSA, 1980, p. 41); mas também octetos em redondilha menor, como o poema laudatório No dia de festejar o nome da senhora condessa de Pombeiro (Ibidem, p. 37) ou o poema Amor generoso (Ibidem, p. 199), foram praticados pelo poeta. Além disso, compôs longos poemas laudatórios, sonetos, peças para teatro musical ${ }^{15}$ (TINHORÃO, 2004, p. 217; RENÓ, 1999).

Porém, é na quadra em redondilha maior ou menor que o autor mais se expressa e a forma predominante nos dois volumes de seu livro Viola de Lereno (Op. cit., 1980). Mas, como dito acima, a arte almeja ser singela e atingir a todos, nobres e fidalgos, pela sensibilidade, desvelada diretamente ao coração (VIEIRA DE CARVALHO, 1999), e não só pela razão: sensibilidade e razão, a cara e a coroa onde todos se irmanam aos olhos ilustrados! Neste aspecto, tal busca torna-se o ápice de um ideal, portanto, a grande sofisticação. E neste aspecto, Domingos Caldas Barbosa, o Lereno Selinuntino da arcádia de Roma, atingiu seu objetivo: foi famoso ainda em vida e, mesmo de origem não nobre, galgou os salões aristocratas de Lisboa onde recitou, tocou e cantou.

Os poemas de Domingos de Caldas Barbosa guardam uma relação não somente com o mundo da cultura popular; mas também trazem uma proximidade com a cultura árcade da época. Com relação à rima, os poemas de Caldas Barbosa adéquam-se inteiramente às questões até aqui levantadas relativas ao mundo árcade: neles impera o formalismo. A tematização do amor é muitas vezes ideal, outras vezes mais sensual e erotizada. Imagens do universo clássico, nomes de musas e cupidos, também fazem parte de seu

\footnotetext{
${ }^{15}$ Para uma lista mais detalhada de sua obra, ver TINHORÃO, J. R. Domingos Caldas Barbosa o poeta da viola, da modinha e do lundu (1714 / 1800). São Paulo: Ed. 34, 2004 pp. 219-25
} 
universo poético. Veja-se a primeira estrofe do poema do volume primeiro do livro Viola de Lereno (BARBOSA, 1980: 37).

\author{
Amira formosa, \\ Escuta os louvores, \\ Que os simples Pastores \\ Vêm hoje entoar: \\ O teu nome ilustre, \\ Subindo às Estrelas, \\ Nos Bosques de Belas \\ Já vai ressoar.
}

Trata-se de um octeto em versos de redondilha menor, o que confere ao poema um ritmo bastante ágil e musical, como assinalados por Mário Faustino sobre os versos de Tomás Antonio Gonzaga (FAUTINO, 2003). Destaquemos que antes do início do poema consta a indicação "cantiga"; o que ocorrerá em muitos outros poemas dos dois volumes ${ }^{16}$, sugerindo que este poema ou possuía uma melodia ou o poeta gostaria que assim o fosse ou que fora efetuado tendo em mente uma forma ou gênero musical. Também a presença de uma de suas musas, Amira, a sugestão do bosque e dos pastores, confere a esse poema uma imagem pastoral e bucólica. Interessa-nos ainda, no poema de Caldas Barbosa, ou no poema árcade em geral, a total consciência da musicalidade que o poema inspira. Veja-se, como exemplo o poema Vou morrendo devagar (BARBOSA, 1980, p. 51), do mesmo volume, em que consta também a indicação de "cantigas" no subtítulo:

Eu sei, cruel, que tu gostas,

Tu gostas de me matar;

Morro, e por dar-te mais gosto,

Vou morrendo devagar

Outro poema do mesmo volume, $A$ dor do meu coração, que traz no subtítulo a indicação "moda", outro gênero musical pertencente ao mundo lusobrasileiro, de onde transcrevermos a primeira estrofe:

Disfarço no alegre rosto

Minha interior aflição;

Porque os outros não conhecem

A dor do meu coração:

\footnotetext{
16 Também encontraremos as seguintes classificações musicais: cantiga, lundu, minuete, modinha, sugerindo o gênero musical associado ao poema (BARBOSA, 1980).
} 
Mais à frente, ainda no volume I da Viola de Lereno, um poema com o título de Minuete (Ibidem, p. 53):

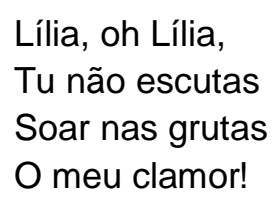

Neste poema, efetuado a partir de versos tetrassílabos, a fluência rítmica aliada ao estribilho também sextilha com versos de quatro sílabas, sobretudo pela acentuação clássica na quarta sílaba do verso, somente quebrado com o acento do verso "Lilia, oh Lilia", com ênfase na primeira e quarta sílabas, sugere uma frase em anacruse, quase a nos convidar a valsar.

A indicação "modinha" aparece em um único poema, Marília brasileira nas Caldas, no volume I da Viola de Lereno, do qual trascrevemos a estrofe segunda:

Fugi de seus olhos

Tão vivos, e belos, Se a Amores, e a Zelos

Quereis escaprar.

[Estribilho]

Amor tem Marília

Por ele ensinada, E quando the agrada

Vos sabe matar.

Embora a palavra modinha apareça no poema Recado, no volume I da Viola de Lereno, "Cantou algumas Modinhas? / E que Modinha cantou? Lembrou algumas das minhas? (Ibidem, pp. 44-45), é a primeira e única vez que é sugerido como subtítulo de um poema. Este, por sua vez, sugere não só certa brasilidade na figura de Marília, a musa de Tomás Antonio Gonzaga e ao gênero modinha, consagrada em algumas liras do poeta inconfidente; mas 
também que desta feita, Marília, será cantada por Caldas Barbosa, também ele, "chegadinho do Brasil" (BARBOSA, 1980, p. 267). ${ }^{17}$

Já a palavra "Lundum" aparece em seis poemas do volume II da Viola de Lereno. No primeiro poema, Lundum de cantigas vagas (Ibidem, p. 238), além da quadrinha tradicional, algumas vocábulos ligados ao mundo cotidiano lusobrasileiro conferem a esse poema um sabor bastante popular:

Xarapim eu bem estava

Alegre nest'aleluia,

Mas para fazer-me triste

Veio Amor dar-me na cuia.

Não sabe meu Xarapim

O que o amor me faz passar,

Anda por dentro de mim

De noite, e dia a ralar.

Meu Xarapin já não posso

Aturar mais tanta arenga,

O meu gênio deu à casca

Metido nesta moenga.

Amor comigo é tirano

Mostra-me um modo bem cru,

Tem-me mexido as entranhas

Qu'estou todo feito angu.

Se visse o meu coração

Por força havia ter dó,

Porque o Amor o tem posto

Mais mole que quingombó.

Tem nhanhá certo nhonhô,

Não temo que me desbanque,

Porque eu sou calda de açúcar

E ele apenas mel do tanque.

Nhanhá cheia de chulices

Que tantos quindins afeta,

Queima tanto a quém adora

Como queima a malagueta.

\footnotetext{
${ }^{17}$ Frase tirada do poema Eu nasci sem coração - BARBOSA. D. C. Viola de Lereno. Rio de Janeiro, 1980, pp. 266-8; musicado com lundu no códice Modinhas do Brasil, LIMA, E. V. As modinhas do Brasil. São Paulo: Edusp, 2001.
} 
Na primeira estrofe, tanto a palavra "xarapim", em sentido de xará, "tirado do meu nome" e a palavra "cuia", cabaça, aqui no sentido metafórico de "cabeça oca". Em outro verso "Meu Xarapin já não posso / Aturar mais tanta arenga”', a palavra "arenga", em sentido de discussão, nos remete ao mundo dos "bons selvagens", os índios brasileiros (BARBOSA, 1980, p. 422). Em outro verso "Qu'estou todo feito angu" "e "Mais mole que quingombó": "angu", espécie de polenta e "quingombó", sinônimo de quiabo, nos remetem ao mundo da cultura negra que, pelo visto, já havia se instado no mundo popular lusobrasileiro (Ibidem, p. 422). Também os pronomes de tratamento,"nhanhá" e "nhonhô", no verso "Tem nhanhá certo nhonhó", são pronomes utilizados pelos escravos ao se dirigirem aos seus senhores. Já adjetivo "chulices", no verso "Nhanhá cheia de chulices", tem o sentido de faceiro, gracioso malicioso ${ }^{18}$, além de também referir-se a um gênero musical: a xula.

\subsubsection{Textos de modinhas de autores desconhecidos}

Ao lado de poemas pertencentes a poetas de renome, encontramos várias modinhas e lundus efetuados sobre poemas anônimos que possuem as mesmas características destacadas nos poemas autorais relativos à forma, ao conteúdo e à métrica. Veja-se, por exemplo, a primeira estrofe do poema: Perdi o rafeiro (SPIX, vol. 1, 1981[1820], p. 259):

Perdi o rafeiro

$\mathrm{Na}$ enchente afogado

Perdi esta guarda

Do meu manso gado.

Na mesma publicação, também a estrofe primeira do poema Escuta formosa Marcia (Ibidem, p. 261):

Escuta formosa Márcia

Tristes ais do teu pastor

São ais qu'a dar lhe ensinou

O tirano Deus Amor.

Ou ainda Uma mulata bonita (Ibidem, p. 300): 18 Para uma discussão mais aprofundada ver: ARAÚJO, Mozart (1963), BEHAGHE, Gerard (1968),
TINHORÃO, J. R. (1991, 1988 e 2004) e LIMA (2006). 
Uma mulata bonita

Não carece rezar

Basta o mimo que tem

Para sua alma salvar.

Ou seja, mesmo cantigas com poemas anônimos, a tendência à metrificação, ao ritmo fluente, aos versos em redondilha menor ou maior, mantém-se o gosto pela simplicidade e pelos versos em ordem direta tão ao gosto árcade e, destaquemos, à cultura popular da época

\subsubsection{O Lundu: poesia popular e ilustração}

Dentro desse contexto, como entender o lundu, não somente em seu aspecto musical (formalismo, baixo de Alberti, ornamentações, entre outros) e cronológico, mas também em seu aspecto poético dentro de uma cultura ilustrada? Evidentemente que tudo que se afirmou sobre a poesia de árcade, uso de ritmo simples, ausência de metáforas, formalismo simétrico, por exemplo, podem ser aplicados aos textos dos lundus cantados no final do século XVIII e inicio do XIX. Veja-se, por exemplo, o texto do lundu Eu nasci sem coração:

Eu nasci sem coração

Sendo com ele gerado,

Porqu'inda antes de nascer

Amor mo tinha roubado.

[Resposta]

Meu bem, o meu nascimento

Não foi como ele nasceu;

Qu'eu nasci com coração,

Aqui está que todo é teu.

Se não tens mais quem te sirva

$\mathrm{O}$ teu moleque sou eu,

Chegadinho do Brasil

Aqui está que todo é teu. 
Apresentamos aqui, evidentemente, apenas algumas estrofes do poema utilizados no célebre lundu encontrado do códice Modinhas do Brasil ${ }^{19}$, e com os versos publicados no volume II da Viola de Lereno (BARBOSA, 1980, p. 266). Suas estrofes estão dispostas em quadra, versos em redondilha maior, rima entre o segundo e quarto verso, bem ao gosto da "literatura popular, onde vale por um verdadeiro poema de forma fixa" (CUNHA \& CINTRA, 2007, p. 706).

Vários outros lundus do final do século XVIII e início do XIX serão construídos com base nesta forma poética, porém, encontraremos algumas variações. O poema anônimo utilizado na peça Xula Carioca de Antonio da Silva Leite ${ }^{20}$ é composto de uma quadra com a tradicional rima no segundo e quarto versos heptassílabos. Porém, seu estribilho, que por sua vez corresponde ao estribilho musical, é composto de uma estrofe de dez versos ${ }^{21}$ em redondilha menor, ou seja, com versos de cinco sílabas, que será quebrada no nono verso, sendo retomada no décimo. Essa diminuição na extensão do verso confere ao poema, e evidentemente à música, uma aceleração rítmica muito ao gosto dos lundus setecentistas:

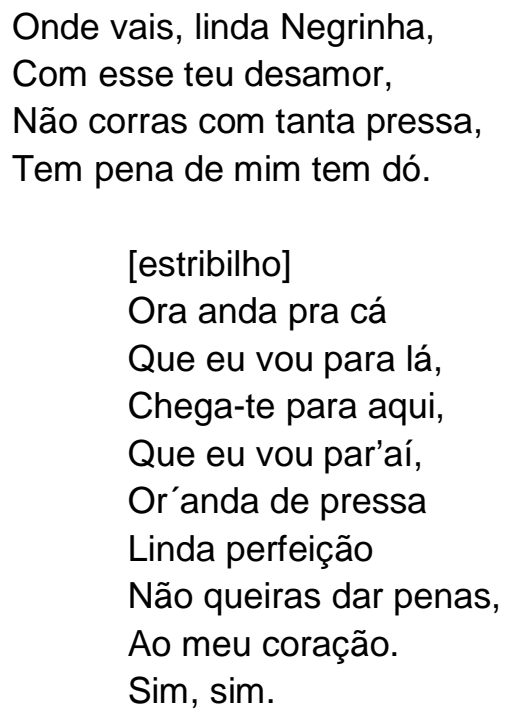

\footnotetext{
${ }^{19}$ Para a pesquisa da música, ver LIMA, E.V. As modinhas do Brasil. São Paulo: Edusp, 2001; para a poesia em sua íntegra, ver BARBOSA, D. C. Viola de Lereno. Rio de Janeiro: Civilização Brasileira, 1980. 20 Apesar do título caracterizar uma "xula", tem características muito próximas do lundu, permitindo sua inclusão nesta texto (ARAUJO, 1963: 115-17).

${ }^{21}$ Se contarmos os versos $10^{\circ}$ como uma espécie de repetição do $8^{\circ}$ e o 9 como uma espécie de reiteração motívica, o que em música chamaríamos de "expansão", a estrofe poderia ser classificada como um octeto oito versos.
} 
Ao meu coração ${ }^{22}$

\subsubsection{Outros exemplos de formas poéticas}

Alguns lundus do século XIX irão utilizar-se da sextilha como forma poética. É o caso dos lundus Menina você que tem de J. F. Leal, Marrequinha da laiá de Francisco de Paula Brito e Francisco Manuel da Silva, Lá no largo da Se de Cândido Inácio da Silva e Manuel de A. Porto Alegre ${ }^{23}$. Porém, ainda se utilizam dos versos de sete sílabas, ou seja, em redondilha maior. Optando, portanto, por um verso de extensão média:

\section{Menina, você que tem}

Menina, você que tem,

Que comigo se enfadou.

Será por que seu cativo,

A seus pés não se curvou.

Façamos meu bem, as pazes,

De joelhos aqui estou.

\section{Marrequinha da laiá}

Os olhos namoradores

Da engraçada laiazinha, Logo me fazem lembrar Sua doce marrequinha.

laiá, me deixe ver a marreca

Se não eu morro, leva-me a breca.

\section{Lá no largo da Sé}

Lá no Largo da Sé velha

'Sta vivo um longo tutu, Numa gaiola de ferro Chamado surucucu. Cobra feroz que tudo ataca, 'Té d'algibeira tira a pataca.

Bravo a especulação

São progressos da nação.

Os dois primeiros lundus, Menina você que tem (J. F. Leal) e Marrequinha da laiá (Francisco de Paula Brito e Francisco Manuel da Silva)

\footnotetext{
22 Transcrevemos apenas a primeira estrofe dos cinco que constam no original; também atualizamos a ortografia segundo os padrões vigentes; para uma consulta na ortografia original ver ARAUJO (1963, pp. 115-17).

${ }^{23}$ Todos esses lundus podem ser encontrados na Biblioteca Nacional do Rio de Janeiro (www.bn.br).
} 
utilizam a sextilha em redondilha maior como forma, usando os dois últimos versos como estribilho musical, aproveitando, evidentemente, que eles funcionam como um mote a ser glosado. Já no terceiro lundu, Lá no Largo da Sé (Cândido Inácio da Silva e Manuel de Araujo Porto Alegre) além do sexteto que dá base a música, há um dístico final que serve de estribilho tanto poético quanto musical. Apesar de esses versos pertencerem ao século XIX, a questão formal e a construção direta dos versos no que tange à fluência do ritmo e dos versos, o aproximam das características formais setecentistas.

O lundu Os me deixas que tu dás (LIMA, 2001, p. 79), já comentado acima, foi elaborado sobre um soneto em redondilha menor: na primeira estrofe, mantém, inclusive, a rima popular entre os versos segundo e quarto. $\mathrm{Na}$ segunda, efetua uma rima abba, ou seja, rima o primeiro com o quarto verso e o segundo com o terceiro internamente. Na quarta estrofe, primeiro terceto, rima o primeiro verso com o último da segunda estrofe e com os dois seguintes. No último terceto, efetua o contrário da estrofe anterior numa espécie de palíndromo: rima o primeiro com o segundo e o último, que é a repetição do primeiro verso do poema, com o último do terceto anterior.

Os me deixas que tu dás

Quando a gentes pega em ti,

São coisinhas tão mimosas

Que nas outras nunca vi.

Muito gosto nhanhazinha

De andar bulindo contigo

Quando vejo que comigo

Tu estás enfadadinha.

Ficas tão muganguerinha

Que muito me satisfaz

E se mando que tu vás

Depois te torno a prender

É somente para ver

Os me deixas que tu dás.

Outro fator a ser destacado nos lundus diz respeito ao seu conteúdo, pois, apesar de tratar do amor, este é tematizado de modo não ideal, mas absorvido direto da realidade cotidiana e, quase sempre, erotizado. Não é novidade a crítica em relação não só a indecorosidade da dança, onde os 
requebros das ancas associado a umbigadas eram vistos pelos olhos ocidentais mais moralistas como algo a ser combatido ${ }^{24}$.

Mas também no lundu-canção, insinuações dos textos utilizados sugerem algo a mais. Como é caso do último verso "Querer bem não presta não" do poema utilizado no lundu Ganinha, minha ganinha (LIMA, 2001: 89). Neste caso, o que não prestaria: estar apaixonado e sofrer as dores de um amor mal correspondido; ou "não presta não" as atitudes que podem advir de um encontro entre um casal apaixonado e buliçoso? Também o lundu Os me deixas que tu dás", onde há insinuações de pegadinhas e beliscões: "Os me deixas que tu dás /Quando a gente pega em ti, / São coisinhas tão mimosas / Que nas outras nunca vi" (LIMA, 2001: 79), são certamente insinuações de um namorico bastante assanhado. De qualquer modo, não encontramos nos lundus do século XVIII insinuações muito fortes, como a que vamos encontrar nos lundus do século XIX. Ao contrário, estas soam bastante ingênuas para nossos ouvidos atuais.

\subsubsection{Crítica social e lundu}

O lundu Já se quebraram os laços construído sobre a popular quadrinha com versos em redondilha maior (heptassíbalo) tradicionalmente rimado no segundo e quarto versos, ao tematizar o amor, ao invés das insinuações erotizadas, efetua um trocadilho entre a liberdade do coração, e a liberdade do cativeiro. Evidente que a crítica é ainda bastante moderada, porém, o uso de palavras como "prisão", "grilhão", "liberdade", nos coloca em face aos problemas escravistas da época. Nesse aspecto, em se tratando do final do século XVIII e de ter sido publicado no Jornal de Modinhas (ALBUQUERQUE, 1996), e dirigido à classe média urbana e aristocrática, esse lundu veicula uma mensagem bastante ousada:

Já se quebraram os laços,

Da nossa antiga prisão, Já não sofro os teus desprezos,

Trago alegre o coração

De amor no tempo em triunfo,

\footnotetext{
${ }^{24}$ Cf.: ARAÚJO, Mozart (1963); MORAIS, M. (2000).
} 
Já pendurei o grilhão,

Restaurei a liberdade,

Trago alegre o coração.

Em qualquer parte que existe,

N'aldeia ou solidão,

Vivo muito satisfeito,

Trago alegre o coração.

Graças aos céus já respiro,

Com toda satisfação,

Nada oprime o meu peito,

Trago alegre o coração.

Outro lundu, La no Largo da Sé de Cândido Inácio da Silva e Manuel de Araújo Porto Alegre, citado anteriormente, composto na primeira metade do século XIX, do qual trancrevemos a segunda estrofe, efetua uma crítica bastante direta da situação política e social da época (Cf. p. 58):

\footnotetext{
Os estrangeiros dão bailes

P'ra regalar o Brasil

Mas a Rua do Ouvidor

É de dinheiro um funil.

Lindas modinhas vindas de França

Nossos vinténs levam na dança.

Bravo a especulação.

São progressos da nação.
}

Não obstante as questões relacionadas com a origem da dança de mesmo nome e suas ligações com o lundu cantado, a poesia que serve de suporte para este gênero, participa seguramente do projeto artístico defendido no século XVIII: se o ideal da racionalidade servirá para a ascensão da burguesia na produção do conhecimento, na política e na construção de uma arte própria e elitizada; a sua contrapartida, a valorização do ideal da sensibilidade e sentimentalidade aliadas ao conceito de natureza da época, vai abrir as portas para a valorização de características que já são praticadas em manifestações populares e que servirão de base para o que chamaremos em música, de Período Clássico. E nesse sentido, a incorporação do homem simples, o camponês, e uma poesia com características populares (simples, sensível, direta) enquadra-se perfeitamente nessa proposta: se o homem deve ser resgatado do obscurantismo e irmanado universalmente, tanto a razão quanto a sensibilidade devem fazer parte desse projeto. 
A critica social, a nosso ver, já faz parte das sátiras populares, e já estão incorporados no Vaudeville e na Comedia Dell'Arte, e que serão base para o teatro da primeira metade do século XVIII em Portugal, os dramas-jocosos nos moldes de Antonio José da Silva, o Judeu, que conjugava a tradição dos bonecos com diálogos e números musicais (VIEIRA DE CARVALHO, 1993, p. 32)

\subsubsection{O popular, a modinha e o lundu}

Evidentemente que nossa intenção neste texto não foi efetuar uma análise crítica da produção poética árcade luso-brasileira, mais enfatizar a relação estreita entre a poesia e música na segunda metade do século XVIII, por isso a escolha de alguns poetas e poemas; e como carregam consigo tendências advindas da cultura popular, mesmo que filtradas e estilizadas pela cultura letrada. Ou seja, como certos aspectos já incorporados na literatura popular, como simplicidade poética, entendida como discurso direto, ausência de metáforas, sugestões musicais, foram elaborados em poemas que serviram como suporte para canções, sobretudo a modinha e ao lundu. Outra questão bastante debatida pelos teóricos, a busca de uma simplicidade no que tange a questão emotiva e, portanto expressiva, também está presente tanto no aspecto poético quanto musical, aproximando ainda mais esses dois mundos: a poesia e a música; o mundo erudito e o popular. A idéia de "simplicidade" foi uma busca consciente, uma elaboração, não uma falta de opção, mas uma verdadeira idéia de emancipação humana, ideológica é claro, em que potencializava não só a razão, mas também a sensibilidade, a outra face de dois lados que nunca deveriam ser considerados separados, mas conjuntamente no entendimento do homo universalis iluminista.

Portanto, ao mesmo tempo em que o iluminismo "promove os valores de universalidade e racionalidade contrapondo-se às práticas populares" (ORTIZ, 1992, pp. 16-7), o ideal da valorização da simplicidade tanto na poesia quanto no canto aproximam a arte desta época aos valores que são praticados por essas camadas. É nesse sentido que a busca poética pelo ritmo fluente, pelo discurso direto e sem metáforas, a tematização da vida no campo na poesia; e a busca pela melodia fluente, a minimização do contraponto, na música, vão 
seguramente abrir as portas, ou os olhos e os ouvidos, para a valorização não só das danças populares que servirá de modelo para a futura melodia articulada (ROSEN, 1986, pp. 68-9); mas também da tradição das comédias populares, como os Vaudeville na França que começa a ser praticada já no final do século $X V I^{25}$ e, sobretudo a Comedia dell'Arte na Itália e que vão influenciar sobremaneira o ideal do ópera no ocidente e por conseqüência, todo um modelo de canção praticada nos salões e sua recepção.

É nesse sentido que vemos a modinha e o lundu: aquela, uma melodia singela e fluente sobre uma poesia com as características acima destacadas. Já o lundu, mesmo com todas as críticas relacionadas às suas características licenciosas de origem, também será incorporado pela cultura da época e cantado, não sem adaptações, pelas diversas camadas sociais no mundo colonial luso-brasileiro da virada do século XVIII pra o XIX e com características ainda mais populares do que a modinha. Ambos serão apresentados, inclusive, como entremez em teatros da época (BARBOSA, 2003, p. 85; TINHORÃO, 2004, pp. 125-34), portanto como espetáculo músicoteatral e, consequentemente, tornar-se-ão cada vez populares.

\footnotetext{
${ }^{25}$ O Vaudeville, Comedia (...) al contrario que la Opera Buffa, incluí diálogos hablados y su música solía ser de carácter tradicional y tomada indiscriminadamente de fuentes respetables y bajas" (BUKOFZER, 2002, p. 266)
} 


\section{Limites da interpretação}

\subsection{O período de ouro da modinha e do lundu}

Nossa intenção neste capítulo não é efetuar uma análise exaustiva de todos os manuscritos (códices) referentes à modinha e o lundu conhecidos até o presente momento, mas proceder a uma reflexão sobre a produção destes gêneros durante o último quartel do século XVIII e primeiro do XIX. A opção por este recorte deve-se ao fato de este ser o período de surgimento e afirmação daqueles gêneros e como eles influenciaram a canção luso-brasileira, tanto da época em questão como posterior. Portanto, nosso enfoque será sobre os códices e manuscritos avulsos que consideramos fundadores de uma futura tradição: a modinha e o lundu. Em segundo lugar, nossa meta não é uma analise exaustiva de cada peça contida num determinado conjunto de documentos, mas o códice como um todo, destacando sua importância para a história dos gêneros em questão, seu estilo e a história, em nosso caso, de tradição luso-brasileira.

\subsubsection{Documentos do século XVIII}

No final do século XVIII, mais precisamente nos últimos 25 anos, a modinha e o lundu já estavam praticamente incorporados à cultura lusobrasileira. Sua entrada na corte se deu, também nessa época, haja vista a grande profusão de músicos que se dedicaram àqueles gêneros e que foram, conseqüentemente, responsáveis pelo ensino musical na época. Com a entrada desses gêneros nos entremezes dos teatros de Lisboa e sua difusão fora dos círculos puramente cortesãos, dos salões da classe média e da intimidade puramente familiar, sua popularização dar-se-ia de modo mais direto.

O lundu, por sua vez, já há algum tempo pertencia às camadas populares, como afirma Tomaz Antonio Gonzaga em suas Carta Chilenas (Cf. p. 22) escritas nos anos que antecederam a Inconfidência Mineira, portanto, anterior a 1789, e que nos dá uma data mais precisa da época que estamos tratando e como o lundu já se apresentava como gênero incorporado à 
sociedade da época. E é justamente neste período (tempo das ariettas em França e canzonettas na Itália) que surgem os códices que serão a base de nossas discussões. Dentre os documentos mais importantes para os gêneros em questão, destacamos o Jornal de Modinhas publicado entre os anos de 1792 e 1796 pela Real Fábrica e Impressão de Música de Pedro Anselmo Marchal, fl. 1789-1814 e Francisco Domingos Milcent, m. 1707, (ALBUQUERQUR, 1996)

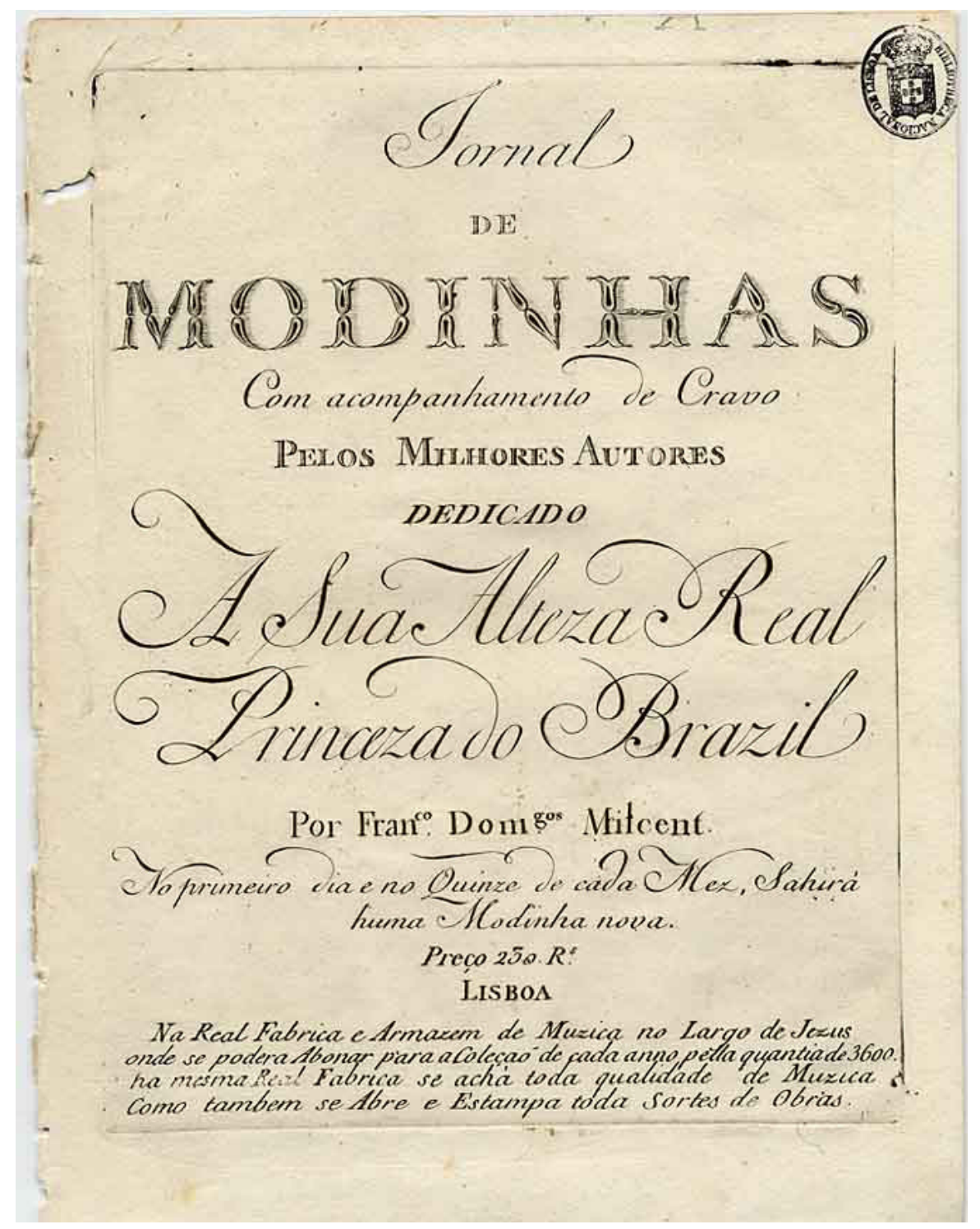

Capa: Jornal de Modinhas, Biblioteca Nacional de Lisboa - PT

Sua publicação era quinzenal e durante os doze meses do ano, alcançando, portanto, a vinte e quatro fascículos anuais, perfazendo um total 
de vinte e quatro peças durante os dozes meses. A publicação durou cinco anos, porém nem todos os jornais foram localizados, estando completos apenas os três primeiros anos: no quarto ano de sua existência, faltam quatro peças, sendo localizadas vinte; e no quinto ano foram localizadas apenas oito peças, faltando, restando quatorze. Dos cinco anos de sua existência, temos, portanto, cem peças musicais entre modinhas e lundus (Ibidem, 1996).

E em cada exemplar foram publicados

"além de modinhas, canzoncinas, ou modas italianas e lunduns, na sua maioria para duas vozes agudas com acompanhamento de cravo ou pianoforte, por vezes de viola francesa, guitarra inglesa ou bandolim e, mais raramente, com baixo simples, sem realização." (Ibidem, 1996, p. ix).

Cotejando os cinco anos de publicação do Jornal de Modinhas, podemos concluir que compositores de renome participaram de suas edições, tais como Marcos Portugal, Antonio da Silva Leite, entre outros. Há modinhas anônimas, mas não figuram com grande profusão, ao contrário, constituem minoria. De qualquer modo, percebemos que havia já na época uma preocupação por parte dos editores em registrar autoria da música e também o autor do texto.

Outro documento de importância capital para nossa pesquisa são os manuscritos MSS 1595 e Mss 1596, denominados Modinhas e Modinhas do Brasil, respectivamente, descobertos pelo etnomusicólogo Gerard Béhague no ano de 1964, nos arquivos da Biblioteca do Palácio da Ajuda, Lisboa, e datados do último quartel do século XVIII (BEHAQGUE, 1968)

Segundo Béhague, o primeiro caderno, manuscrito 1595, traz doze modinhas dentro do estilo português característico da segunda metade do século XVIII: duas vozes, ambos sopranos, geralmente em terça e sextas paralelas, com acompanhamento de cravo, neste caso, quase sempre dobrando as vozes. Outro aspecto a ser destacado é o fato dos sopranos estarem dispostos no centro dos quatro pentagramas, estando editado o manuscrito na seguinte disposição: o primeiro pentagrama, em clave de sol na segunda linha, dedicado ao acompanhamento do canto; o segundo e terceiro pentagramas, em clave de dó na primeira linha, dedicados ao canto; o quarto, em clave de fá, para a linha do baixo. 


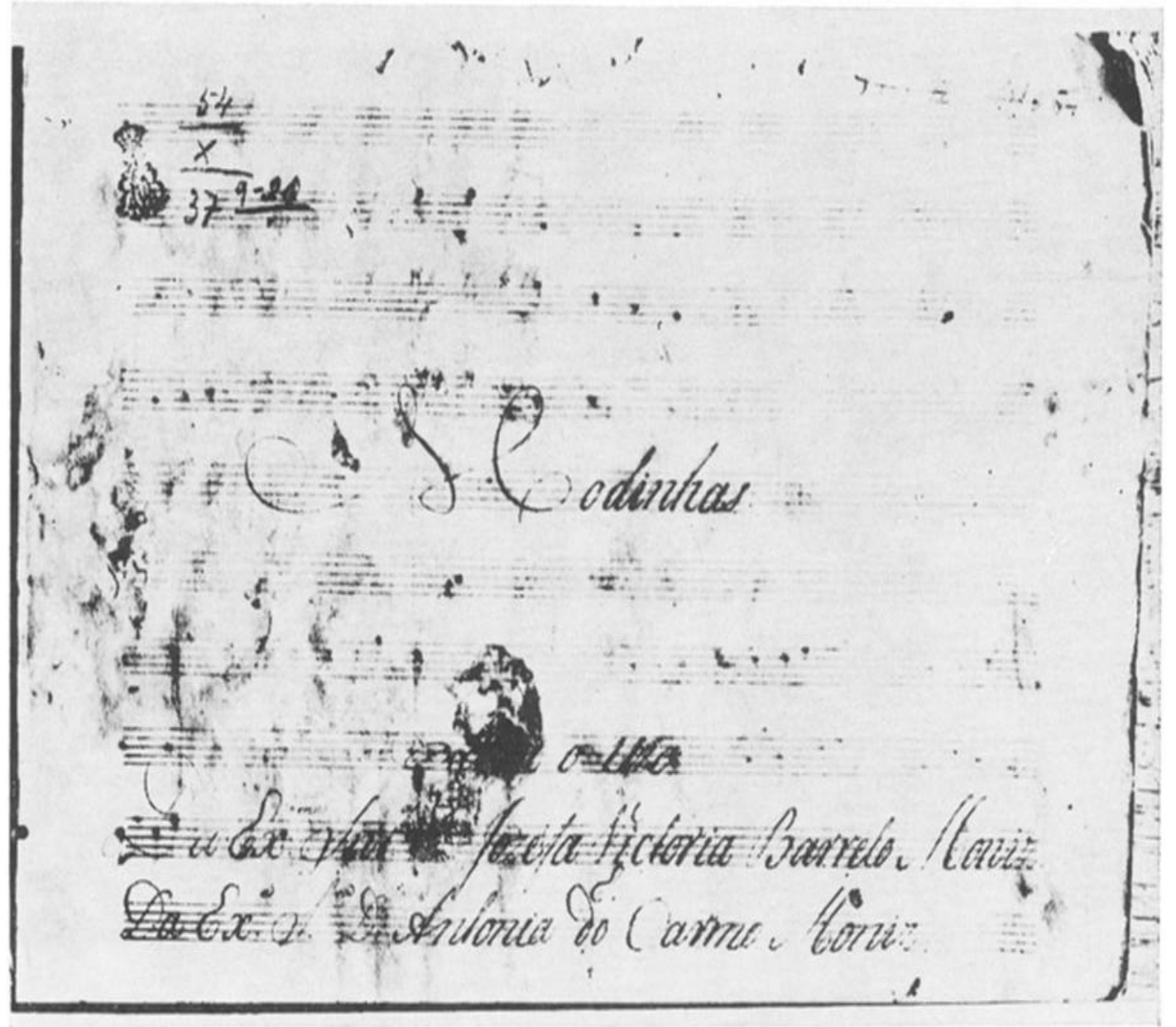

Capa do MS 1595 - Modinhas, Biblioteca do Palácio da Ajuda Lisboa - PT

O segundo códice, o manuscrito 1596, traz trinta modinhas, e como acusam seu título, supostamente brasileiras. Como o manuscrito anterior, foi escrito para duas vozes femininas, utilizando claves de dó na primeira linha, excetuando a peça de número 8 (Quem ama para agravar), que está escrita na clave de sol para as duas vozes. O baixo que acompanha as vozes está disposto em uma única linha em clave de fá na quarta linha, sem a realização do acompanhamento, à guisa de baixo contínuo. Em várias peças há a presença de cifras na linha do baixo, ora acima, ora abaixo das notas, orientando a realização e, sobretudo, as inversões. Em algumas peças, os arpejos dispostos na linha do baixo nos sugerem acordes efetuados para viola, ou guitarra, tanto inglesa quanto francesa. 


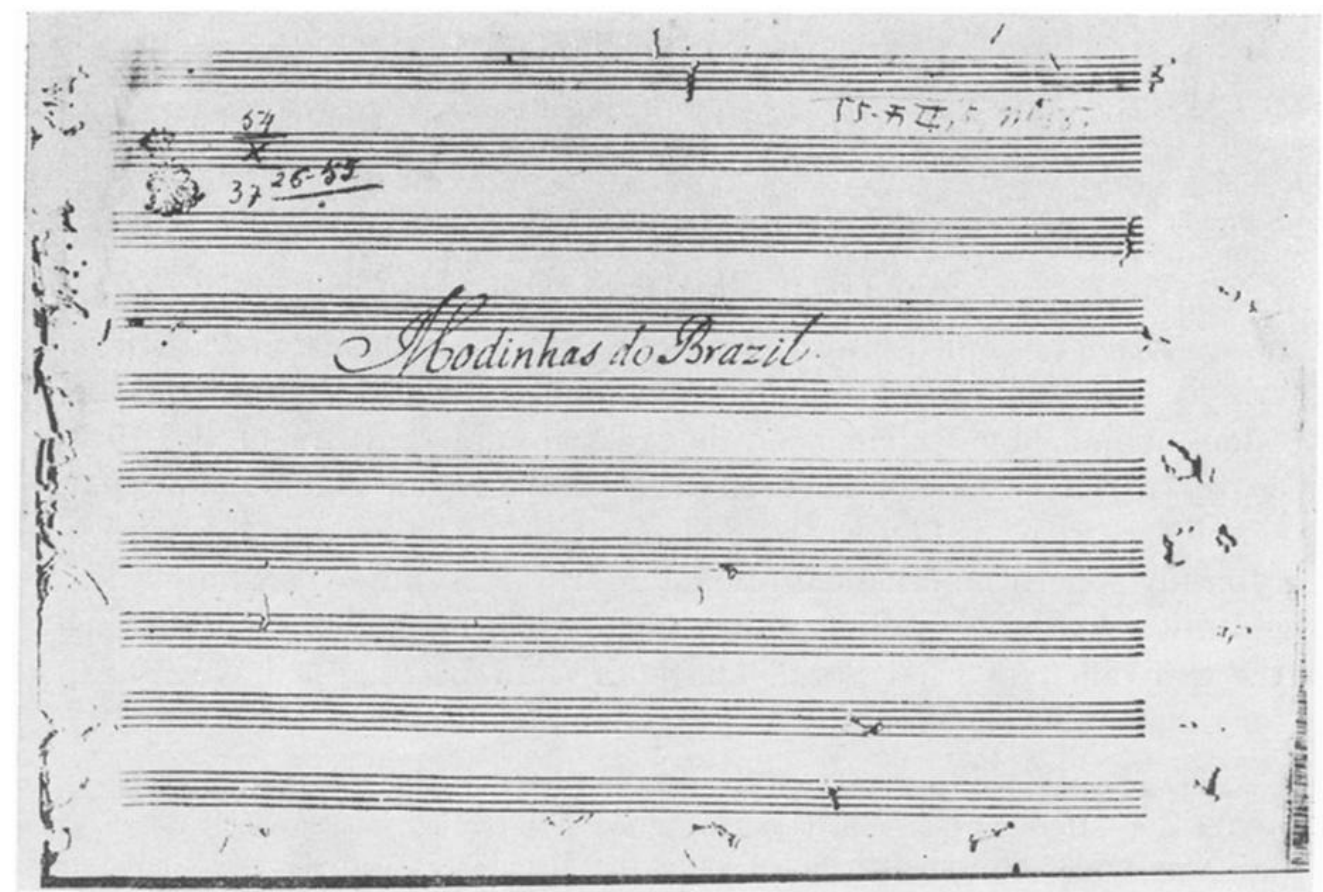

Capa do MS 1596 - Modinhas do Brasil, Biblioteca do Palácio da Ajuda Lisboa - PT

Apesar da publicação do artigo de Béhague ter sido efetuado antes do início da década de 1970, mais precisamente em 1968, os anos mais difíceis do panorama político brasileiro, ela só veio a ter grande repercussão nos anos subseqüentes ${ }^{26}$ e os primeiros registros contendo modinhas e lundus desses dois importantíssimos manuscritos só vieram a ocorrer na década de 1980 em diante.

$\mathrm{Na}$ época, Gerard Béhague, aventou ter descoberto as modinhas até então nunca reveladas de Domingo Caldas Barbosa, o Lereno Selinuntino da Arcádia de Roma, muito famoso já em sua época e residente neste final de século em Lisboa, cantador de modinhas e lundus, tangedor de viola e emigrado do Brasil na década de $1763^{27}$. De fato, duas peças do manuscrito em questão, o lundu Ganinha, minha ganinha e a modinha Homens errados e loucos, utilizam poemas de Domingos Caldas Babosa, mas não trazem assinatura de autoria das respectivas músicas. Já as demais peças contidas no documento, todas de autoria anônima, tanto da música quanto dos poemas,

\footnotetext{
${ }^{26}$ Cf. KIEFER (1977); O long play dirigido por Zé Maria Neves na década de 1985; o long play dirigido por Manuel Veiga, Modinhas e Lundus - Bahia Musical (1984). Após a década de 1990, vários registros serão efetuados e comentados no texto A modinha e o lundu: 50 anos de registro musicais.

27 Domingos Caldas Barbosa tem sido um personagem pivô no que tange a história da modinha e do lundu; para mais detalhes, Cf.: BARBOSA (2003), TINHORÃO (2004).
} 
não foram identificadas como poema do Lereno Selinuntino e muito menos a música.
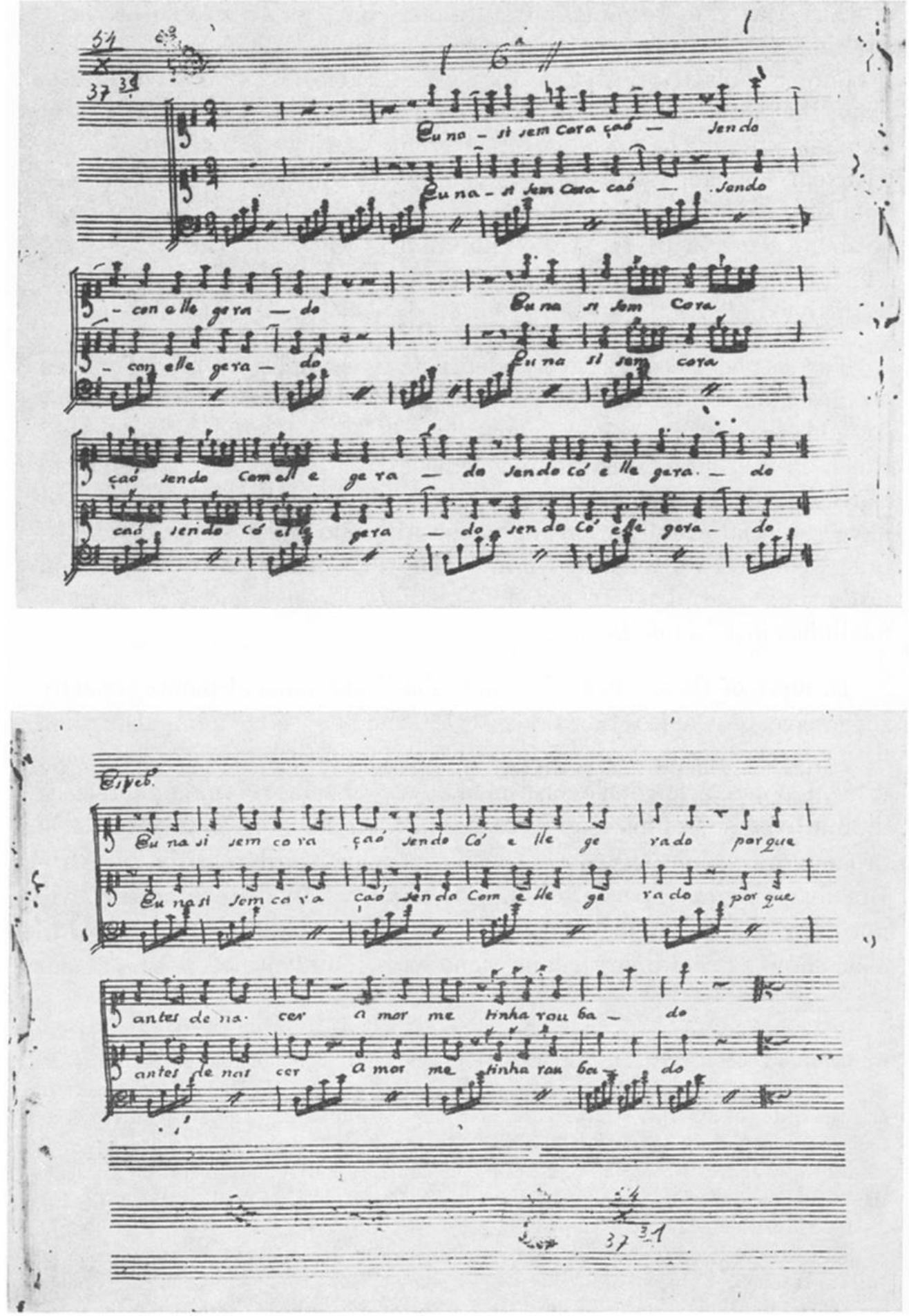

Eu nasci sem coração, Modinhas do Brasil, no. 06 - Biblioteca da Ajuda, Ms. 1556 

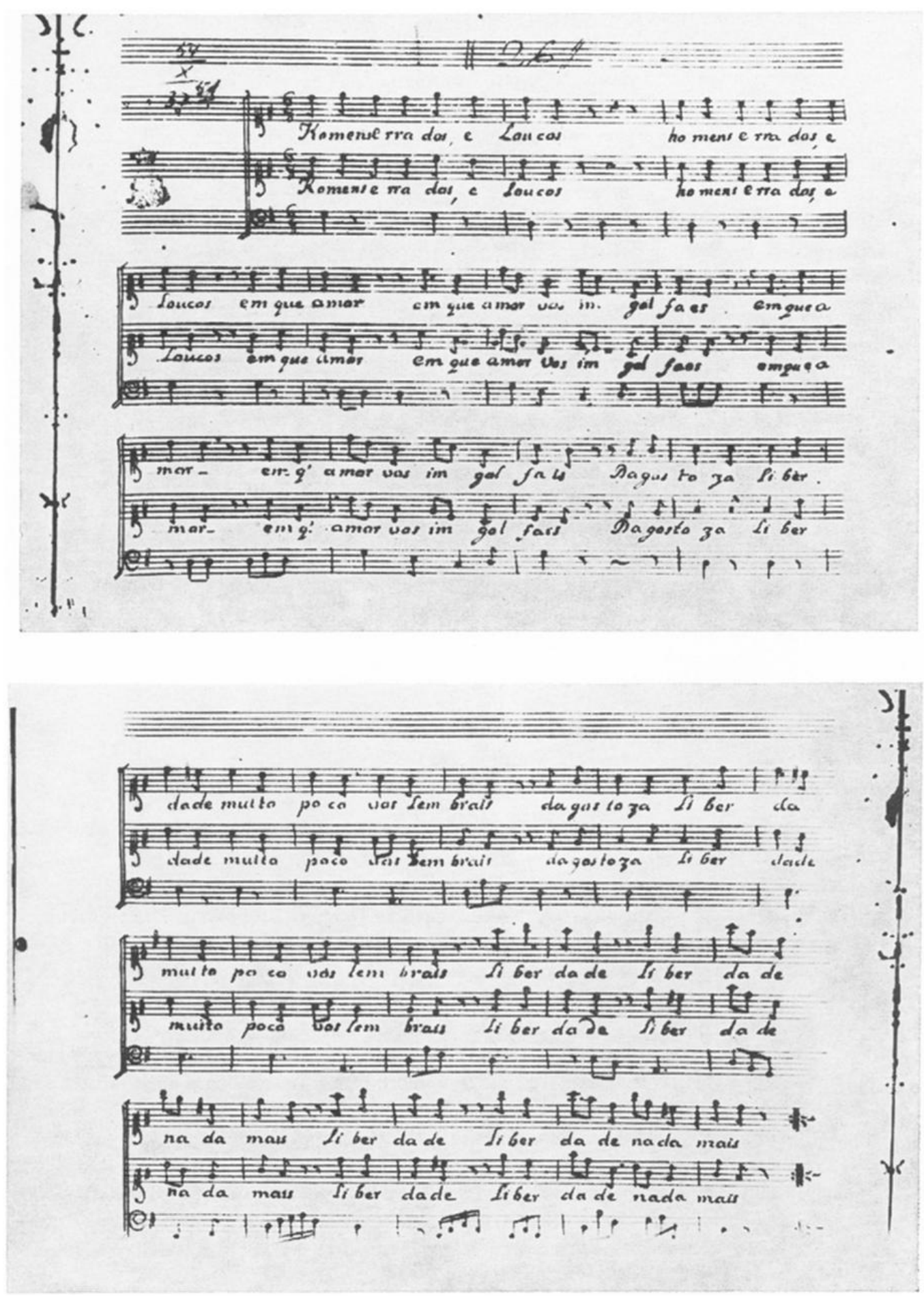

Homens errados e loucos, Modinhas do Brasil, no. 26-Biblioteca da Ajuda, Ms. 1556

Apesar do excelente trabalho de Béhague em artigo pioneiro que apresentou algumas peças em fac-símile, este códice foi posteriormente publicado em sua totalidade, ou seja, todas as peças foram editada no padrão atual e questões levantadas por Béhague no artigo de 1968 foram rediscutidas 
(LIMA, 2001). Porém, questões relativas à autoria das demais peças e seus respectivos estilos, tanto poético quanto musical, assim como problemas relacionados com a interpretação, serão alvo de nossos escritos nos capítulos seguintes. No exato momento devemos nos ater à importância desse documento para a história dos gêneros em questão. Contudo, o que nos chama a atenção num primeiro momento, é o fato da quase a totalidade das modinhas reconhecidas como brasileiras, nunca indicarem nome do compositor, nem do texto poético e tampouco da música; o que destoa muito da opção do Jornal de Modinhas acima comentado.

Com a descoberta desse manuscrito, trinta novas peças, entre modinhas e lundus, foram colocadas, e de uma só vez, ao alcance dos pesquisadores e, logo em seguida, dos interpretes interessados no repertório (Ibidem, 2001). De qualquer modo, e como comentado acima, essas peças somente passarão a ser alvo de publicações e gravações após a década de 1980 e, especialmente, 1990 !

O que mais chamou a atenção nesses manuscritos foi o fato de haver dois cadernos específicos: um especificamente contendo modinhas; outro, contendo modinhas brasileiras, ou seja, contendo peças que supostamente traziam características do que teria sido o estilo praticado nas modinhas e lundus compostos na colônia, anteriores ao século XIX. Não queremos com isso suscitar discussões acaloradas e defender uma autonomia nacional, avant la letre, ou seja, antes de sete de setembro de 1922; ao contrário, queremos apenas comentar a posição do musicólogo em questão e sua, por que não dizer, felicidade em poder divulgar um documento que polarizaria uma parte da história da modinha e do lundu por alguns anos e sua incontida emoção, nos idos da década de sessenta e, portanto, a mais de quarenta anos, por ter efetuado tal descoberta.

Cremos, a partir e juntamente com Béhageue, que a etnomusicologia e a musicologia atual ainda está por compreender o que representa em termos estilísticos o Mss. 1956, mas reservaremos esta discussão, também, para os capítulos que seguem. No memento queremos destacar que a publicação do artigo em 1968 injetou novos ânimos em pesquisadores portugueses e brasileiros preocupados com a modinha e lundu e sua ligação com a identidade musical luso-brasileira. 
Outro códice, e não de menor importância, Muzica escolhida da Viola de Lereno, Ms. 4801 da Biblioteca Nacional de Lisboa, datado de 1799, traz quarenta cantigas, entre modas, modinhas e romances a uma, duas e até, três vozes, efetuadas todas sobre poemas de Domingos Caldas Barbosa. O acompanhamento, às vezes está realizado para teclado, ou seja, cravo ou fortepiano; e às vezes traz apenas a linha do baixo, como na tradição das cantatas e árias barrocas e dos tonos humanos ibéricos, semelhante ao códice Modinhas do Brasil, e diferentemente deste, sem indicações de cifras (BARBOSA, 2003).

O manuscrito em questão não traz indicação do compositor, ou compositores das cantigas. Sabemos que poemas de Caldas Barbosa pertencentes a outros manuscritos, a saber o Jornal de Modinhas, foram musicados por compositores de renome na época, como Marcos Antonio da Fonseca Portugal (1762-1830), Antonio Leal Moreira (1758-1819), Antonio José do Rego (fl. 1783-1865) e Venance Aloise (fl. 1794). Dois textos seus foram transformados em óperas: uma, $A$ vingança da cigana pelas mãos de Antonio Leal Moreira e outro, A Saloia Enamorada, pelas mãos de Marcos Portugal (www.bn.pt/manuscritos). Isto confirmaria uma relação, se não amistosa pelo menos estreita entre o poeta e dois músicos renomados na corte antes de sua morte em 1800.

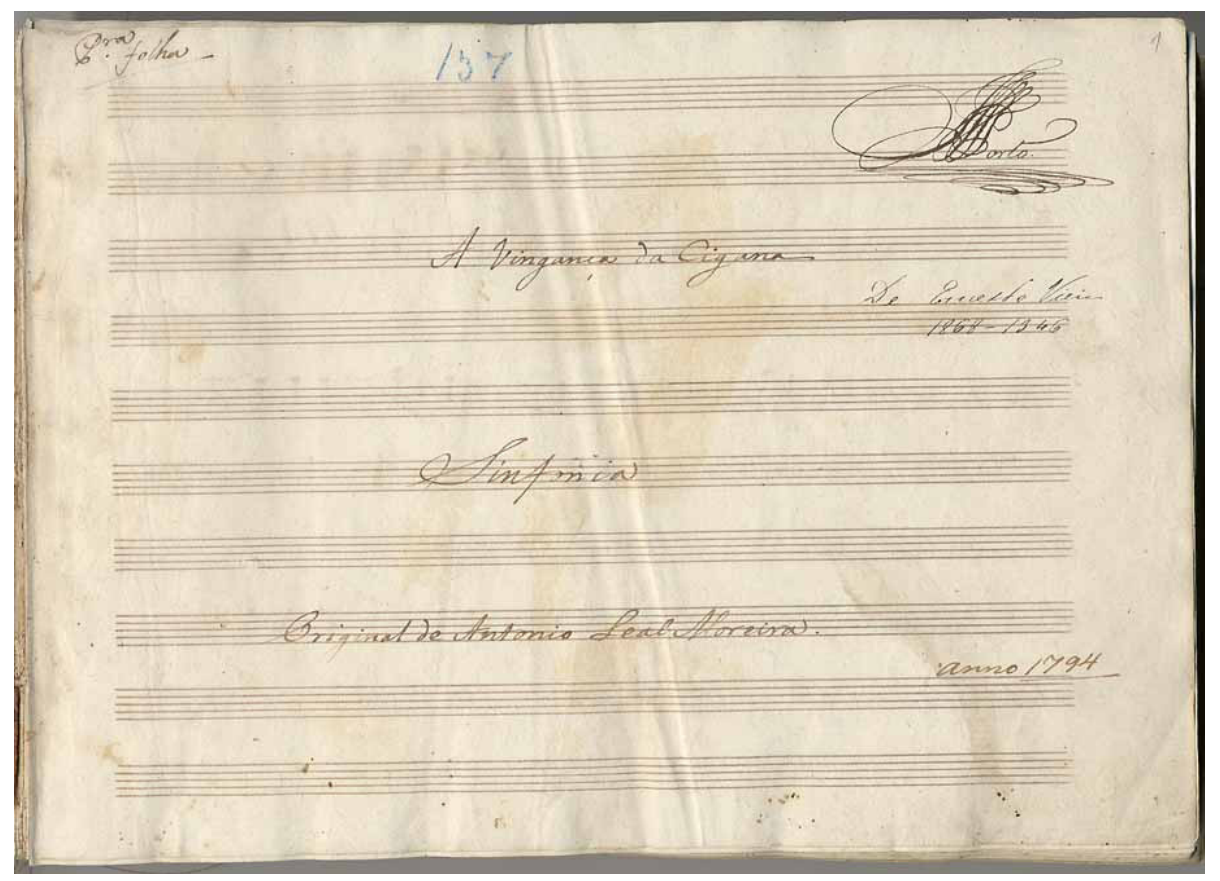

Capa: A vingança da Cigana, Biblioteca Nacional Lisboa - PT 
O que primeiro nos chama a atenção nesta coleção é seu título, Muzica escolhida da viola de Lereno (sic), sugerindo haver outras que foram preteridas, ou seja, não escolhidas. Levando-se em consideração o códice Muzica escolhida... com quarenta poemas e também o manuscrito Modinhas do Brasil, contendo dois poemas do autor em questão, somam-se quarenta e dois (42) poemas de Caldas Barbosa transformados em cantigas e conhecidos até o presente momento.

O pesquisador Manuel Morais identificou outros sete poemas e os respectivos compositores das músicas (Ibidem, 2003), fazendo, portanto, um total de quarenta e nove (49) poemas conhecidos até os dias de hoje que foram colocados em música. Porém, somente sete poemas possuem autoria da música, restando uma quantidade considerável de poemas que ainda não foram identificados os devidos autores das cantigas. Então, nos acomete outra pergunta: porque os compositores que efetuaram músicas para os poemas não foram identificados, como ocorreu com Marcos Portugal, Antonio da Silva Leite, por exemplo? Seria impossível a alguém que toca viola e se acompanha ao cantar modinhas e lundus compor, como se diz na atualidade, de ouvido? O caso de Joaquim Manoel da Câmara é muito sintomático, pois, tal que qual Domingos Caldas Barbosa, toca, cantava e compunha de ouvido e somente ficamos sabendo deste fato, porque suas músicas foram escritas por Sigismund Neukomm (FAGERLANDE, 2008; CRUZ, 2000). Porém, não estamos querendo afirmar que Lereno Selinuntino foi compositor, pois, como veremos mais à frente, isso não é de suma importância para a esta pesquisa; mas estamos apenas levantando uma possibilidade não que seria improvável.

\subsubsection{Documentos do século XIX}

Outro documento que chama muito a nossa atenção, intitulado Jornal de Modinhas novas dedicadas as senhoras (sic), publicado por João Baptista Waltmann no ano de 1801, é composto por dez modinhas composta por vários autores, tais como: José Palomino (1 e 7), Antonio José do Rego (2 e 8), José Mauricio da Cap. Real de Coimbra (4 e 10), Giovanni Giuseppe Baldi (5 e 11), Marcos Antonio Portugal (6), José Ma. Franchi (9). Algumas características merecem ser destacadas em relação a este códice: primeiro, todas as peças 
trazem autoria musical, o que não ocorre nos códices Modinhas do Brasil e o Muzica escolhida da Viola de Lereno; segundo, todas as peças estão efetuadas para canto (solo ou duo) com acompanhamento de piano-forte, diversamente do manuscritos acima citados, que além de realizadas para instrumento de tecla, também efetuam acompanhamentos a maneira barroca, em que constam apenas as linhas do baixo, à guisa de baixo contínuo, sem realização; no caso do códice Modinhas do Brasil, algum baixos trazem cifras, aproximando este manuscrito a um tipo de escrita mais antiga ou à música religiosa, que continua utilizando a técnica do baixo contínuo em suas partituras, até o final do século XVIII (DUPRAT, 1985).
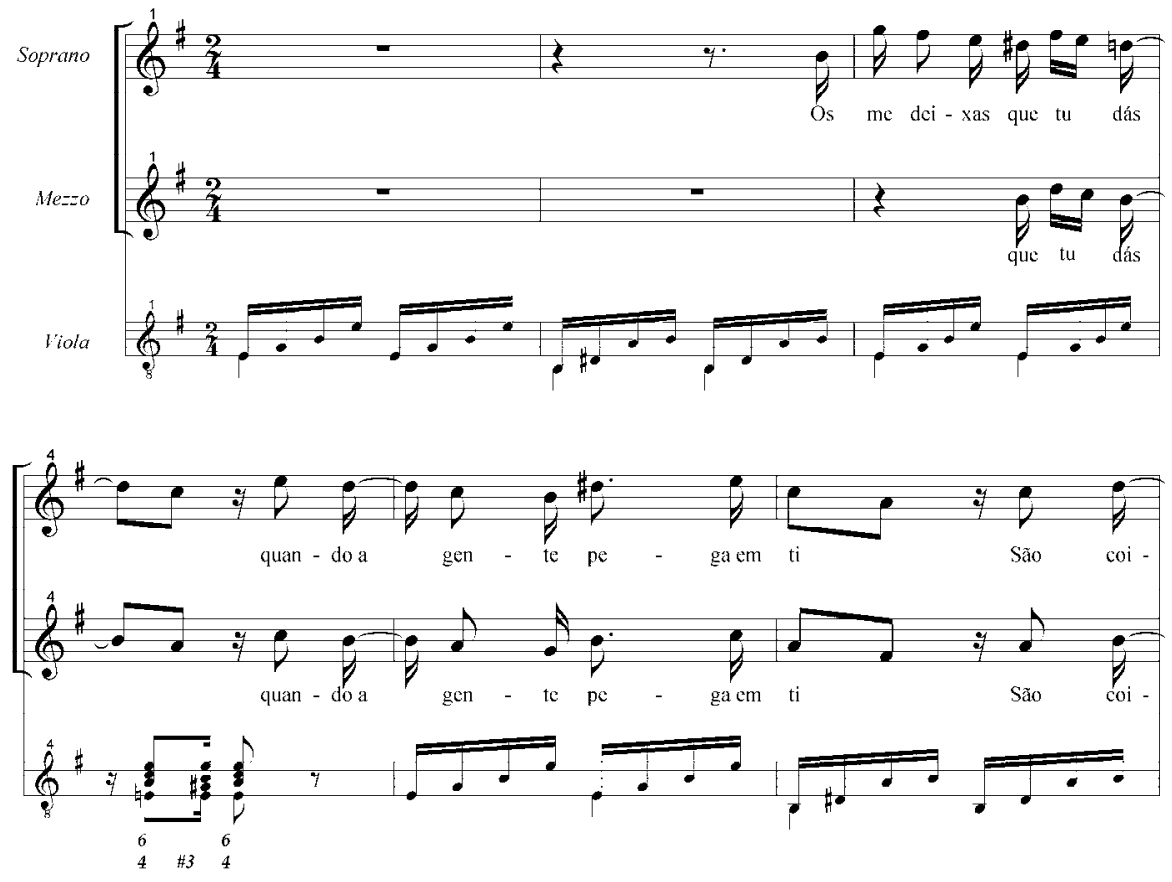

Os me deixas que tu dás (trecho), Modinhas do Brasil, no. 5- Biblioteca da Ajuda, Ms. 1556

Portanto, neste documento e no Jornal de Modinhas há uma preocupação por parte dos editores com a identificação tanto do autor da música quanto do autor do poema; e um breve olhar sobre a produção musical no século XVIII, já bastaria para atestar a importância da identificação dos autores numa composição para voz. O que estranha, como assinalado acima, é o anonimato de alguns códices, tais como Modinhas do Brasil e Muzica escolhida da viola de Lereno: por que não houve a preocupação com a 
identificação do compositor, ou compositores nestes dois documentos? Voltaremos a essa questão mais adiante.

O que percebemos também, é que a partir da virada do século XIX, as modinhas a duo irão escasseando, dando lugar às modinhas a solo. No manuscrito Modinhas do Brasil, todas as peças são a duas vozes. Já no códice Muzica escolhida..., de um total de quarenta peças, uma possui escrita a três vozes, duas são para uma voz e as trinta e sete restantes, para duas vozes. Nas peças publicadas durante os cinco anos de circulação do Jornal de Modinhas, há, notadamente, uma acentuada preferência pelos duetos. Mas, a partir da virada para o século XIX, haverá a predominância de canções a solo.

Outro códice, 20 modinhas portuguesas (CRUZ, 2000) onde constam as cantigas de Joaquim Manoel Gago da Câmera ${ }^{28}$ harmonizadas por Sigismund Neukomm, tem sido bastante citado e gravado nos últimos anos, pois, além de disponibilizar cantigas de um dos mais destacados modinheiros da virada do século XVIII para o XIX, traz as harmonizações de um dos discípulos diletos de Josef Haydn (Ibidem, 2000). O exemplar mais conhecido deste códice encontra-se na Bibliotèque Nationale de France, Section de Musique, de Paris e foi publicado por Gabriela Cruz em 2000. Porém, noticias anteriores de sua existência remontam a década de 1950/60 divulgadas pelo pesquisador Mozart de Araújo (FAGERLANDE, 2008, p. 12).

Segundo Marcelo Fagerlande, além dos dois exemplares da Biblioteca Nacional da França, um rascunho e a versão completa, outra edição dessas modinhas encontra-se na British Library (FAGERLANDE, 2008, p. 17); e outras modinhas avulsas do mesmo autor foram localizadas na Biblioteca Nacional de Lisboa, Ó minhas ternas saudades (Ibidem, p. 20). Além disso, o autor nos informa no mesmo artigo, de outros exemplares descobertos por Luigi Fernando Tagliavini na Itália e na Alemanha (Ibidem, p. 21). Apesar dessas novas notícias a respeito da grande difusão das modinhas de Joaquim Manoel fora do mundo luso-brasileiro, não há descoberta de novas peças, apenas combinações das 20 que se encontram na Biblioteca da França.

\footnotetext{
${ }^{28}$ Segundo pesquisa recente efetuada por Marcelo Fagerlande, após extensa pesquisa em arquivos portugueses, na Biblioteca Nacional da França, na British Library e arquivos musicais da Biblioteca de Madrid sobre a obra do autor e recomposição da árvore genealógica do compositor, descobriu o nome correto do compositor é Joaquim Manoel Gago da Câmera e de família originária da ilha dos Açores (FAGERLANDE, M. Brasiliana, no. 27 - 2008, pp. 11-24)
} 
Outra noticia divulgada pelo professor Manuel Morais, na sua introdução efetuada para a publicação do códice Muzica escolhida... (BARBOSA, 2003), nos informa da existência de modinhas levadas para Londres, supostamente por William Beckford, e que serão por ele trabalhadas e publicadas em breve. Morais, na mesma obra, nos adverte ainda que haja modinhas brasileiras não pesquisadas na Biblioteca Nacional de Madrid, Espanha (Ibidem, 2003: 85-86). Portanto, há ainda arquivos institucionais e supostamente coleções a serem pesquisadas e incorporadas às histórias da modinha e do lundu. De qualquer forma, acreditamos que novas descobertas não mudarão de modo fundamental o entendimento que temos hoje desses dois gêneros, a despeito da possibilidade de preencher algumas lacunas.

Pesquisas efetuadas no arquivo Curt Lange do Museu da Inconfidência de Ouro Preto em Minas Gerais, têm revelado quantidade não insignificante de modinhas e, em menor quantidade, de lundus. Em sua grande maioria, trata-se de peças do século XIX e datadas da década de 1840 em diante. Porém, duas das peças desse arquivo merecem ser incluídas como sendo do século XVIII: a modinha Quando na verde campina e do lundu Cupido tu és travesso.

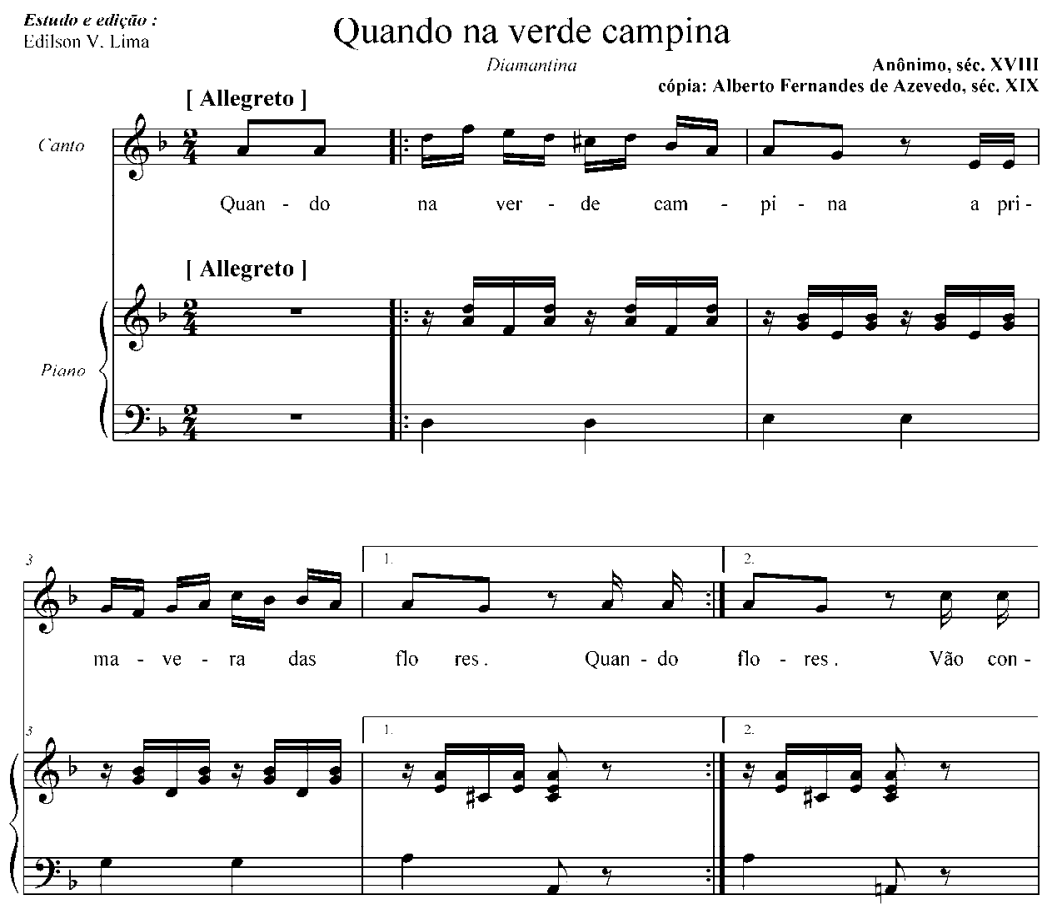

Quando na verde campina (trecho) - Arquivo Curt Lange, MIOP - MG 


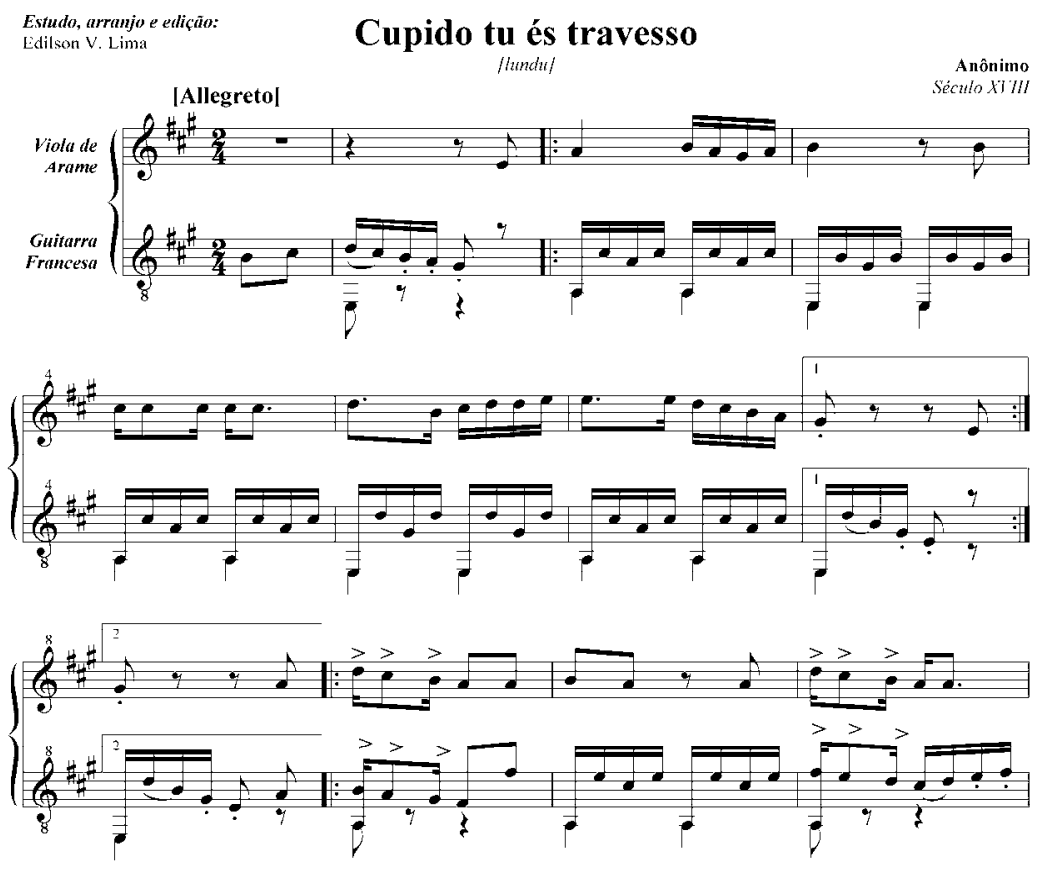

Cupido tu és travesso, (trecho) - Arquivo Curt Lange, MIOP - MG

Das duas peças, ambas escritas ao final da linha do baixo do Himnus Ad Laude, este, datado do século XIX, apenas uma delas traz texto completo, a modinhas; o lundu tem apenas excertos. As melodias estão escritas com a mesma caligrafia e na clave de soprano na primeira linha. O texto da modinha traz como musa a figura de Nerina, pastora que inspirou vários poemas de Domingos Caldas Barbosa, o Lereno Selinuntino (BARBOSA, 1980; RENÓ, 1999). Outro fator, a questão formal tanto musical quanto poética também nos sugere, não só pela sua simplicidade, mas, sobretudo, pela simetria, serem peças do último quartel do século XVIII.

Além das coleções acima destacadas, encontramos em acervos das principais bibliotecas, tais como, Biblioteca Nacional de Portugal, Biblioteca do Palácio da Ajuda, modinhas e lundus avulsos, ou seja, que não pertencem a coleções específicas. Muitas dessas peças foram estudadas por pesquisadores, tanto brasileiros quanto portugueses e foram alvo de nossas discussões neste texto.

No início do século XIX, impulsionado pela transferência da corte para o Rio de Janeiro e, sobretudo, pela liberação da imprensa, começam a aparecer as primeiras edições contendo coletâneas de modinhas e lundus e até mesmo edições avulsas. Ao pesquisarmos o acervo da Biblioteca Nacional (RJ), 
chamam a nossa atenção, além das modinhas e lundus avulsos, duas coleções, uma contendo modinhas de Gabriel Francisco Trindade, outra com modinhas e lundus de J. F. Leal.

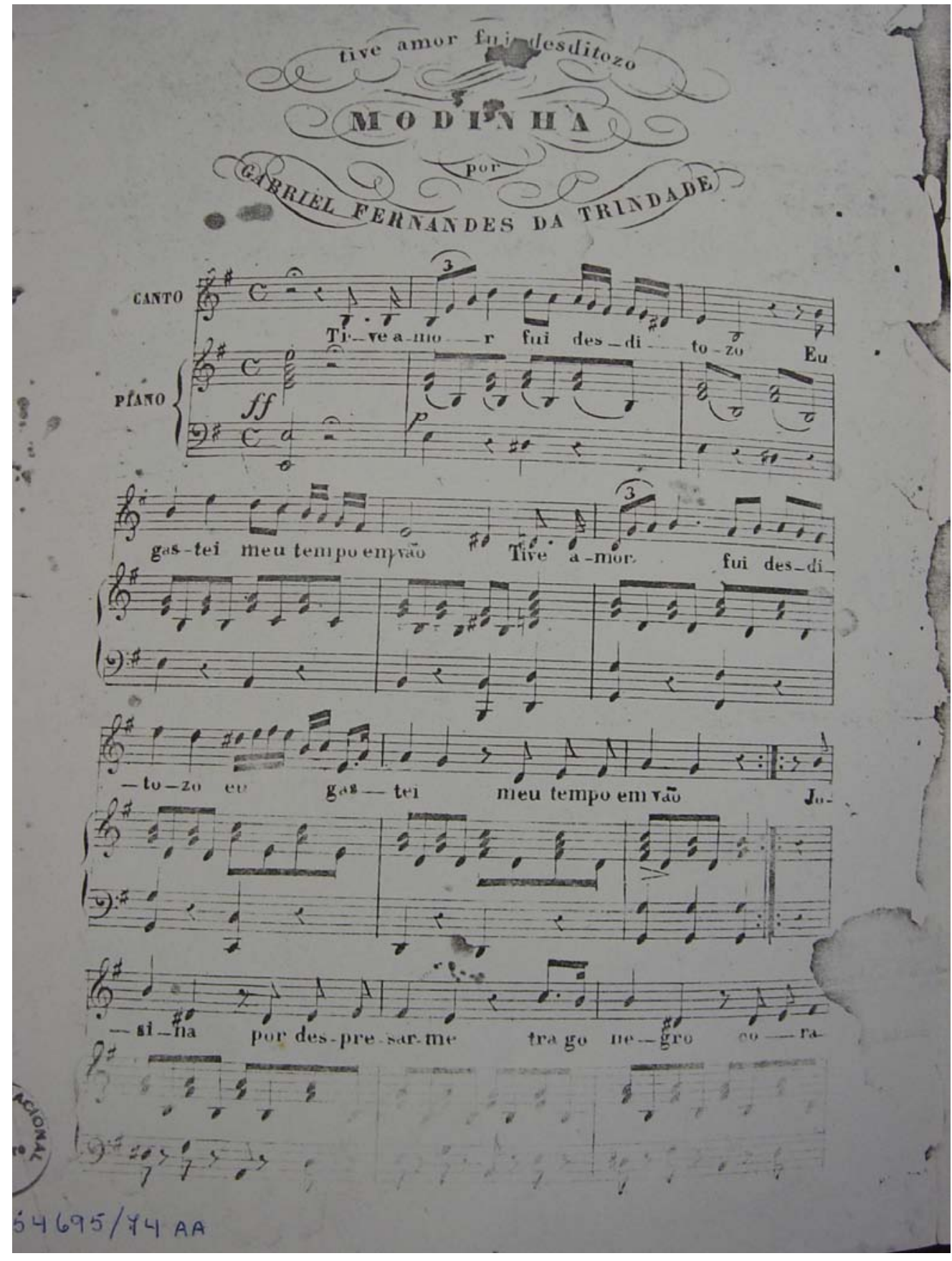

Trecho de modinhas e Gabriel Fernandes da Trindade - Biblioteca Nacional, RJ.

Gabriel Fernandes da Trindade (1790-1854), compositor e cantor de modinhas, foi também violinista da Capela Imperial atuando entre os anos de 1823-31. Após essa data, viveu como animador de festas e cantor profissional 
(CASTANHA, 1995). No acervo da Biblioteca Nacional do Rio de Janeiro encontramos, pelos menos, vinte peças impressas em litogravura, entre modinhas e lundus, com acompanhamento de piano. Suas peças apresentam já um sabor romântico, sobretudo no que diz respeito ao conteúdo poético e um estilo musical rossiniano (PARCHECO, 2008: 296).

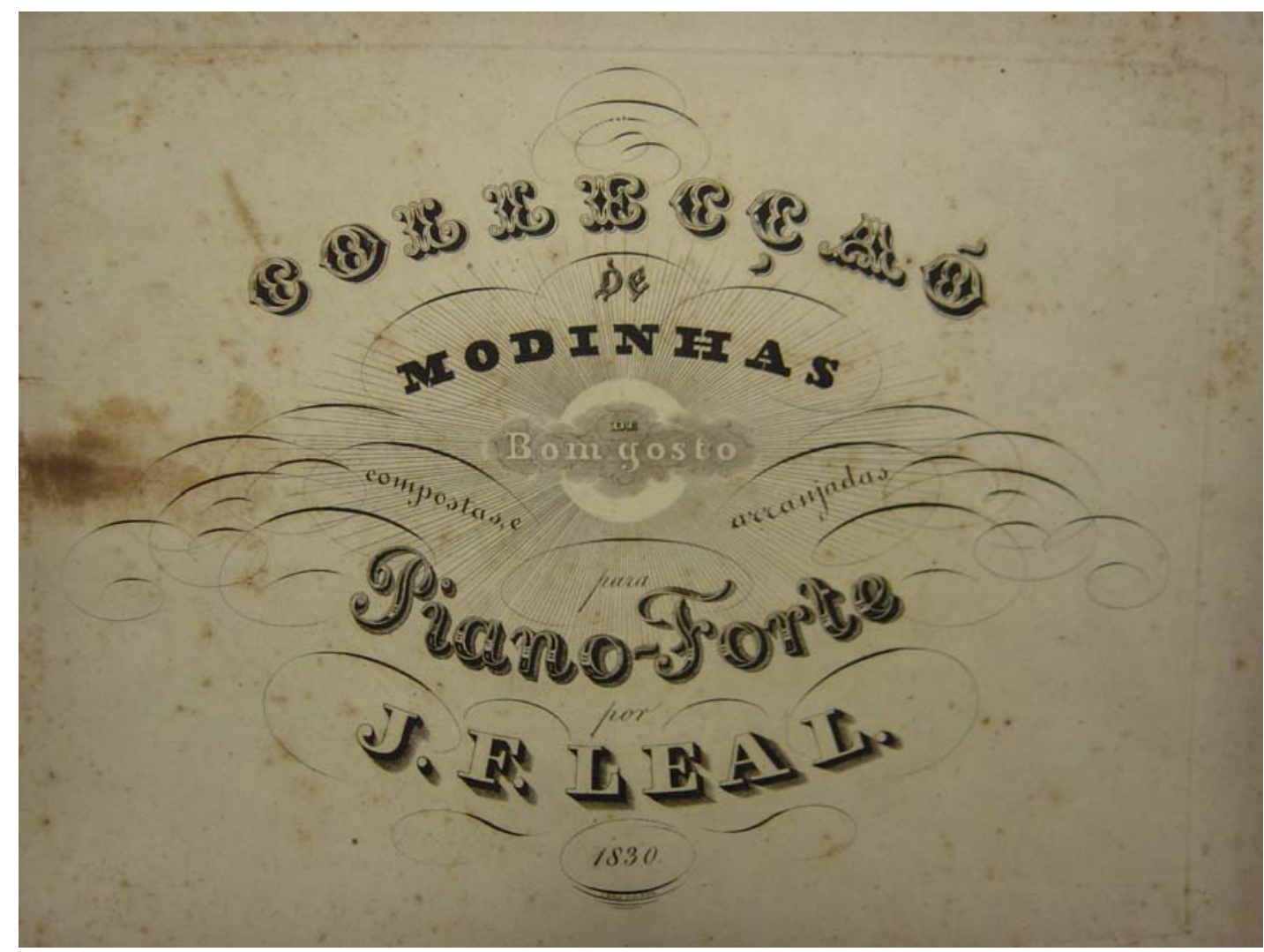

Capa, Coleção de modinhas de bom gosto, J. F. Leal - Biblioteca Nacional, RJ.

A coleção de João Francisco Leal, intitulada Coleção de modinhas de bom gosto, acreditamos que foi um grande sucesso na sociedade carioca da época, pois além da publicação bastante trabalhada que se encontra na Biblioteca Nacional e datada de 1830, há peças suas em um manuscrito pertencente à Biblioteca Estatal Bávara (BISPO, s/d) e partituras de sua autoria também em Lisboa e publica no livro Modinhas luso-brasileiras (DODERER, 1985). Gostaríamos de frisar que uma das modinhas mais gravadas, Beijo a mão que me condena de José Mauricio Nunes Garcia, um dos principais músicos da corte de dom João $\mathrm{VI}$, encontra-se nessa biblioteca. Porém, discussões mais aprofundadas sobre a questão estilística dessas peças, serão reservadas para os capítulos que seguem. 
Já a coleção de lundus avulsos do acervo da Biblioteca Nacional, somente apresenta partituras imperiais. Certamente que esse grupo de peças nos interessa, porém, como nossa pesquisa está focada na modinha e no lundu colonial, partituras posteriores a esse recorte certamente serão estudadas, mas, sobretudo para podermos entender o que representaram esses dois gêneros no período em questão e seus possíveis desdobramentos.

\subsubsection{Os viajantes}

Um grupo de partituras que nos chama atenção e que tem constituído referência a pesquisadores nacionais e internacionais, está contido no livro Viagem pelo Brasil: 1817 - 1820 (SPIX, 1981). Este livro é o resultado da viagem efetuada pelo botânico dr. Carl Friedrich Philipp von Martius e o zoólogo dr. Johann Baptist von Spix entre 1817 e 1820, e financiada pelo imperador Francisco I da Áustria, pai da rainha Leopoldina, Arquiduquesa da Áustria e esposa de dom Pedro I.

A viagem empreendida pelos dois cientistas tinha como objetivo principal o estudo da flora e fauna brasileira. Porém, os viajantes deixaram-se fascinar pela sociedade como um todo e decidiram, também, anotar aspectos dos costumes do povo da terra. Como resultado, os três volumes que compõem esse grande estudo trazem ao final um apêndice contendo vários cantos de índios brasileiros da época, sete modinhas e um lundu. Cabe destacar que as peças contidas no apêndice musical trazem identificação seja da etnia indígena à qual pertence $\mathrm{e}$, no caso das modinhas e do lundu, da região em que foram recolhidas. Desvelam, portanto, traços importantes do cultivo musical em São Paulo, Bahia, Minas Gerais e Goiás.

Dentre as peças contidas no apêndice musical desse livro, está presente um dos lundus mais gravados da história desse gênero, Lundum, Brasilian Volkstanz. A partitura manuscrita foi transcrita apenas com a melodia, ou seja, sem acompanhamento. O que nos chama atenção, em um primeiro momento, é o esmero com que essas cantigas foram incluídas num estudo de botânica e mineralogia. Todas, além de cópia de excelente caligrafia, trazem indicação da região onde foi recolhida, excetuando o lundu. Com relação aos cantos indígenas, há inclusive o cuidado de identificar a qual etnia pertenciam. 
Acreditamos que não poderíamos encerrar esta parte sem mencionar o Cancioneiro de musicas populares de Cesar das Neves, trabalho de grande envergadura, em três volumes, publicado em Lisboa no ano de 1895, com o objetivo de compilar, com o nome mesmo indica, canções populares da tradição portuguesa. Com esta publicação, o autor desvelou várias peças de importância fundamental para a história da modinha que, sem sua contribuição, estariam seguramente perdidas. Neste aspecto destacamos as doze árias por ele publicadas sobre poemas de Tomás Antônio Gonzaga e que hoje fazem parte da história desse gênero e do repertório gravado.

Conforme temos atestado em nossas pesquisas, as modinhas e lundus, por se tratarem de peças para serem apresentadas em ocasiões menos formais, tais como salões aristocráticos e da classe média, festas particulares, pelo menos no inicio; e por pertencerem, sobretudo a acervos particulares, salvo as coleções do Jornal de Modinhas, ou o Jornal de Modas Novas dedicados... a grande maioria das coleções pertencem aos próprios compositores ou aqueles a quem as coleções foram dedicados. Isso dificultou, certamente, sua preservação e tem dificultado a ampliação desse repertório.

No Brasil, tivemos a agravante de não podermos efetuar impressões antes de 1808, dificultando ainda mais a possibilidade de edições e por conseqüência, sua distribuição e conservação. Também o fato de dois dos mais conhecidos cantores de modinhas e lundus, Domingos Caldas Barbosa e Joaquim Manoel da Câmara, terem fixado residência em Lisboa, sugere que suas produções por lá ficaram. Acrescente-se a isso, a questão de que esses dois gêneros consistiam de música para "puro entretenimento". Nesse sentido, podemos entender a escassez de documentos relativos a esses gêneros em arquivos coloniais antes da formação de 1822, portanto, antes de nossa emancipação política.

\subsection{Do romantismo à sua superação}

\subsubsection{Antecedentes no século XIX e a virada para século XX}

As pesquisas sobre a modinha e o lundu surgem no inicio do século $\mathrm{XX}$, e absolutamente comprometidas com a construção de uma identidade 
nacional. No século XIX, mais especificamente nos anos que antecederam e sucederam à proclamação da República, as discussões relacionadas com a unidade identitária para o Brasil, estavam em alta. Mesmo no período imperial, a fundação do Instituto Histórico e Geográfico Brasileiro em 1837 (REIS, 2000), já havia atentado para a "construção" de uma possível unidade nacional. Também datam do século XIX, os estudos de Silvio Romero (1851-1914), Nina Rodrigues (1862-1906) e Euclides da Cunha (1866-1909) já voltados para uma futura unidade nacional fundada nos parâmetros de raça e meio (Ortiz, 1994 e 2003; SCHWARCZ, 1993). Mas com a aproximação da proclamação, a possibilidade do regime republicano e a emancipação política brasileira, discussões sobre um futuro ou possível caráter nacional, não poderiam mais ser adiadas.

O século XIX já havia demonstrado um grande potencial, pelo menos nos centros urbanos, de absorção de influências e sínteses de gêneros europeus e "tradições" locais já sedimentadas na colônia, que resistem ao império e conduzem ainda alguns anos, à primeira república ${ }^{29}$. Neste aspecto, além da música da ópera e da música religiosa, podemos elencar uma grande quantidade de gêneros que faziam parte do mundo musical da segunda metade do século XIX: modinhas, lundus, valsas, polcas, mazurcas, habaneras, polcas-tango, polcas-habanera, polcas-lundus, são alguns exemplos de gêneros que faziam parte do universo musical das várias camadas sociais urbanas da época (DUPRAT, 1999; KIEFER 1983). De qualquer modo, a combinação de substantivos para tentar definir um gênerosíntese, já constitui uma tentativa de dar conta de gêneros que estavam por nascer, ou já não mais correspondiam, ipsis literis, ao gênero em questão.

A primeira e grande tentativa de construção de uma identidade brasileira, foi o indianismo. Esta corrente se manifestou principalmente na literatura, em romances como O Uruguai (1769) de Basílio da Gama, Caramuru (1781) de Santa Rita Durão, e Iracema (1865) e O Guarani (1857) de José de Alencar, este, o romance referencial de base para a ópera homônima de Antônio Carlos Gomes (1836-1896). Longe de ser apenas uma narrativa

${ }^{29}$ Os gêneros que nos propomos estudar nascem já no século XVIII comprometido com possíveis identidades locais: a modinha é identificada por poetas e viajantes da época como tendo características brasileiras; e o lundu nasce deste lado do Atlântico Sul sintetizando características que podem ser reputadas não só a vertentes européias, mas também características locais advindas da cultura negra na colônia (NERY, 2005; BARBOSA, 2003; MORAIS, 2001; LIMA, 2001 e 2006) 
preocupada em elencar características para a literatura brasileira do momento, o indianismo foi um primeiro discurso "ideológico relacionado com o mito da origem nacional e o tema da relação inter-étnica e da miscigenação" (VOLPE, 2002).

No campo da música de tradição oral, muita coisa restava por fazer, e neste aspecto, as pesquisas de Silvio Romero publicadas no último quartel do século XIX, sobretudo o Folclore brasileiro: cantos populares brasileiros (1985 [1883]), História da literatura brasileira (2001[1888]), Compêndio de história da literatura brasileira (2001[1906]) vêm suprir uma lacuna bastante significativa para a época. Pertencente à escola do Recife, Romero, não só pesquisou a literatura popular, mas articulou em seus estudos, conforme o pensamento da época, duas categorias que considerava de fundamental importância para a formação de uma futura nação brasileira: a noção de meio e a categoria de raça (ROMERO, 2001[2006]; ORTIZ, 2003, p. 15). Essas duas categorias estavam absolutamente ligadas às idéias deterministas em voga na segunda metade do século XIX: um determinismo racial; outro, um determinismo geográfico (VOLPE, 2008).

Ou seja, Romero não mais se valia do mito da origem, recorrendo a um tempo mítico no passado, perdido nas brumas de algum igarapé ou em algum fundo de sertão ainda desconhecido e de difícil localização no tempo e no espaço para justificar o nascimento de uma nação. Ao contrário, nessa "nova" articulação entre meio e raça, o conceito de povo está vinculado a um espaço geográfico determinado onde vivências e intercâmbios de valores comuns podem sintetizar novas articulações culturais e, portanto, sociais. Conseqüentemente, o Brasil nesta visão, ainda está por ser inventado. Dizendo de outra forma, nosso passado, segundo esta visão, ainda não havia produzido uma amálgama cultural suficientemente consistente para dar rosto a uma nação coesa, una, possuidora de uma unidade identitária: mas o futuro, segundo essa visão, prometia.

É nesse sentido que interpretamos as pesquisas de Silvio Romero relacionadas à cultura popular e, especificamente, à modinha no final do século XIX: a busca de manifestações culturais que refletissem uma autonomia e servissem de base para a afirmação de uma suposta identidade própria. E não somente isto, pois, a modinha, devidamente folclorizada, retrataria uma 
absorção que acusava sua aceitação por parte das camadas populares, ou seja, sua porta de entrada no seio do povo, como dito acima, a síntese da nação.

Como observado acima, as teorias vigentes no final do século XIX e que vão continuar em voga no inicio do XX, estão ligadas a duas categorias muito importantes para as pesquisas antropológicas européias do século XIX: os conceitos de meio e raça (ORTIZ, 2003). No século XIX, essas teorias, todas calcadas no pensamento positivista, representavam o que havia de mais atual em pesquisas folclóricas e objetivavam acabar com o diletantismo em pesquisas neste campo e aí instaurar métodos científicos de atuação. Mas na Europa do inicio do século $\mathrm{XX}$, esses conceitos já estavam sendo questionados (Ibidem, 2003).

Não era de estranhar que no Brasil do final do século XIX, com os ventos da república a soprar, se procurassem naqueles fervorosos dias, não sem avidez, supomos, teorias culturais que embasassem e justificassem uma identidade nacional para além de uma já consolidada unidade política. E a modinha como foi deficida por Romero, música de cunho popular e, sobretudo, pela sua ligação com a poesia popular que lhe servia de base, era uma excelente candidata para uma síntese relacionada com as teorias mesológicas e raciais:

"Há uma música que se pode chamar brasileira. Aparece hoje quase toda anônima. Não há uma província do Brasil que, desde os mais remotos tempos, não contasse com certo número de músicas notabilíssimas, cujas produções foram sempre apreciadíssimas. Não sendo publicadas, desapareceram sem deixar lembrança dos nomes de seus autores. Julgo pelo que se passou em Sergipe, minha pátria. É enorme o número de modinhas, de quadrinhas, de marchas, de musicas sacras, de fantasias, todas de um sabor especial, expressões impretéritas de um espontâneo gênio artístico de súbito valor. Entretanto, correm anônimas e vão desaparecendo." (ROMERO, 2001[1888]).

É importante destacar que ao enaltecer a modinha, Romero não cita o lundu, apesar de que, diversamente dos românticos que o precedem, se preocupa mais com a questão racial do que com a geográfica (ORTIZ, 2003, p. 18). De qualquer modo, a miscigenação, mais do que uma solução, passa a ser um problema, pois ao aceitarmos que características sócio-culturais possam ser transmitidas geneticamente, "o mestiço, enquanto produto do cruzamento entre raças desiguais, encerra, para os autores da época, os defeitos e taras 
transmitidos pela herança biológica" traduzindo assim "a realidade inferiorizada do elemento mestiço concreto" (Ibidem, p. 21); conservando, "preconceitos de natureza racista e pessimista (DUPRAT, 2001, p. 225). Neste aspecto, o lundu, ao carregar as marcas da influência negra, deveria ser tratado seguramente com mais cuidado. Foi nesse sentido que o "branqueamento" tornou-se o ideal a ser perseguido no século XIX:

"É na cadeia da evolução social que poderão ser eliminados os estigmas das 'raças inferiores', o que politicamente coloca a construção de um Estado nacional como meta e não como realidade presente" (ORTIZ, 2003, p. 21).

Retornando um pouco mais atrás, o IGHB já havia atentado para esta questão. Ainda que de modo não muito profissional, pois associando profissionais e amadores preocupados com o futuro da nação brasileira, atrelava-se ainda à figura do imperador dom Pedro II e, supostamente, muito ligado ao monarquismo, regime que muitos queriam ver superado, porém, sem prejuízo de uma desagregação nacional. Neste sentido, e num primeiro instante, as teorias vigentes no século XIX, sobretudo a articulação entre "meio" e "raça" comentadas acima, representaram as bases para a construção de teorias interpretativas sobre a cultura brasileira para além da figura do monarca, calcadas em concepções científicas positivistas e, na interpretação da época, universalistas.

Outro problema a ser ressaltado foi a voga anti-lusitana após 1822 e acirrada no período da regência de dom Pedro I. Nesse aspecto, as discussões, pelo menos nessa época, passam não somente pela busca de caminhos próprios; mas e, sobretudo por discussões que validassem qual o limite aceito entre lusitanismo e brasileirismo (RIBEIRO, 2002). Evidentemente a voga anti-lusitana dos primeiros anos da independência será minimizada com a política de dom Pedro II. Mas o advento da República como discutimos acima, impõe questões que colocam em cheque nossa dependência, que ainda persistiria, em relação à Europa. E esse tema vai se espraiar, e não sem razão, para o mundo das artes e, por conseguinte, se instaurar no mundo da música.

\subsubsection{A semana de arte moderna e a orientação pós 1922}


Sem dúvida, e como acenado acima, a proclamação da República não impunha apenas mudanças jurídicas e institucionais, mas ao contrário, nesta nova fase, a recusa da monarquia e, sobretudo, de um imperador português, atentava para uma autonomia também cultural e não somente social e política. Foi nesse sentido que os gêneros em questão adentraram as discussões empreendidas por intelectuais preocupados com a unidade cultural brasileira no final do século XIX, que só no século $X X$ tomará proporções realmente nacionalistas. Dessa forma, todo um movimento de renovação estética que se inicia na primeira e na segunda década do século XX e que vai culminar com a Semana da Arte Moderna em 1922, começa a questionar não só a hegemonia da oligarquia cafeeira que ditava os rumos políticos; mas também em que medida nossa herança cultural até aquele momento, servia ou não de base para a construção de uma identidade cultural nacional. Porém, mesmo contrapondo-se à estética romântica, toda a literatura referente à modinha e o lundu, num primeiro momento, conservará em sua base as teorias referentes ao meio e à raça, trazidas ao Brasil na segunda metade do século XIX, e a vinculação dessas teorias com a cultura popular e folclórica. Nesse sentido, 0 modernismo brasileiro oscilava entre a superação do romantismo e a busca de uma tradição que pudesse justificar nosso caráter popular (TRAVASSOS: 1997 e 2000; CONTIER, 1985).

Também o ideal desenvolvimentista calcado numa cultura cosmopolita, principalmente de identificação francesa da sociedade do final do século XIX - a belle époque brasileira - passa a ser alvo das críticas dos intelectuais do inicio do século XX, sobretudo, de Mário de Andrade, que se colocava, evidentemente, a favor da busca de um caminho próprio. De qualquer modo e dentro desta visão, o Brasil também estava ainda por ser construído; ou seja, ainda pertencia a um futuro almejado e/ou projetado. E mesmo em seus últimos escritos, como $O$ Banquete, que foi concebido entre os anos de 1943-1945, persiste o "futurismo nacionalista":

"Os artistas brasileiros são primitivos sim: mas são 'necessariamente' primitivos como filhos de uma nacionalidade que se afirma e dum tempo que está apenas principiando" (BANQUETE: 2004[1945], p. 143)

E o futuro que Mário de Andrade ambicionava passava pelo conhecimento de nossa cultura popular de tradição oral, para ele, a morada da 
alma brasileira. Justamente por esta razão pode afirmar que "uma arte nacional já está feita na inconsciência do povo" (ANDRADE, 1962 [1928], p. 16). E algumas linhas mais à frente, retomando sua visão, reafirma:

"O período atual do Brasil, especialmente nas artes, é o de nacionalização. Estamos procurando conformar a produção humana do país com a realidade nacional" (Ibidem, 1962[1928], p. 16).

Neste sentido, a publicação da coletânea de partituras intitulada Modinhas Imperiais (1980[1930]) por Mário de Andrade constitui um marco no que diz respeito ao estudo da modinha e do lundu. Publicada originalmente em 1930, a coletânea traz uma compilação de quinze modinhas e um lundu, todos datados do século XIX e selecionados pelo autor. Com esta publicação serão tratados não só aspectos ligados à origem dos gêneros em questão, ou seja, discussões ligadas aos aspectos identitários; mas também questões ligadas à forma, ao estilo e à interpretação musical. Alguns desses aspectos serão potencializados em publicações que se seguem. Porém, a questão da origem da modinha e do lundu e sua ligação com a construção de nossa identidade cultural, serão mantidas, e sempre dentro de um aspecto nacionalista.

Para Mário de Andrade, a modinha é um gênero musical estreitamente ligado à burguesia e à classe média no século XVIII, ou como classifica, à "musicalidade burguesa" (Ibidem, p. 5). Andrade não discute o fato de a modinha ser portuguesa ou brasileira e até acusa os defensores de sua origem brasileira de certo patriotismo. Porém, destaca o valor desse gênero, sobretudo por sua "significação importante na complexidade musical brasileira" (Ibidem, p. 5); e por esta razão, como ele mesmo afirma, "não merece ficar no ostracismo de nossa ignorância". (Ibidem, p. 5). Concluímos, portanto, que segundo sua visão, tanto a modinha quanto o lundu, merecem a atenção dos pesquisadores. Porém, o que mais estranha a Mário de Andrade é o fato desse gênero ter passado às camadas mais populares e, sobretudo, ter-se folclorizado. Nesse aspecto, sua entrada no mundo da cultura oral, representaria o passaporte para o "inconsciente nacional" destacado acima, ou seja, sua entrada definitiva na alma "povo".

Nesse sentido, as pesquisas efetuadas por Baptista Siqueira e publicadas em 1957 no livro Modinhas do passado, respondem à questão Andrade. Assim sendo, a modinha se folcloriza de fato e, portanto será 
incorporada à cultura oral. Mas antes mesmo das pesquisas efetuadas por Siqueira e no texto de 1930, Andrade, em uma afirmação mesologista, já tentava justificar a "brasilidade" da modinha:

"A Modinha se originou só do formulário europeu. A sensualidade mole, a doçura, a banalidade que lhe é própria (e que também coincidia com um estado de espírito e de arte universal no tempo, como já indiquei) só lhe pode provir da geografia, do clima, da alimentação" (ANDRADE, 1980[1930], p. 7).

Conseqüentemente, a vinculação entre o meio, a raça e a cultura, serão as bases de Andrade na busca de uma imaginada nação, e nesse aspecto, dá continuidade as teorias advindas do século XIX (VOLPE, 2010, pp. 5-6). E não era sem razão que no Ensaio sobre a música brasileira, alguns anos antes, Andrade já apontasse a importância de uma unidade racial, sem a qual não haveria uma unidade cultural: "Os artistas duma raça indecisa se tornaram indecisos que nem ela" (ANDRADE, 1962[1928], p. 13). Portanto, fazer coincidir a "alma do povo" que se encontra no folclore e a produção artística individual torna-se seu projeto nacionalista. Ou, dizendo de outro modo, "lograr uma conversão profunda dos músicos e fazer coincidirem expressão individual e expressão nacional" (TRAVASSOS, 2000, p. 9)

E foi justamente pensando na construção de uma "nação" no futuro, que Andrade pôde caracterizar seu projeto nacionalista em fases: numa primeira fase, dar-se-ia o período de renovação estética, ou seja, caracterizada "na luta contra o 'passadismo', representado grosso modo pelo romantismo, na música, e pelo parnasianismo, na poesia" (Ibdem, p. 19). As principais características do romantismo a serem combatidas na música seriam, portanto, a grandiloquência, o sentimentalismo e o descritivismo (Ibidem: 19); já na poesia, fazia-se necessário rever "o rigor das regras de metrificação e rima, aliadas a temas e vocabulários anacrônicos" (lbidem, p. 20). Numa segunda fase, decorrência natural da primeira, "enfatiza a preocupação com a realidade brasileira e introduz o tema da nação nos debates culturais e estéticos, gerando uma mudança de tom que fará com que, mais tarde, se fale de modernismo nacionalista" (Ibidem: 21), portanto uma fase construtivista.

Neste sentido, para que a modinha, e por conseqüência o lundu, pudessem ser aceitos como gêneros autenticamente brasileiros e adentrassem ao projeto modernista, era necessário vencer dois problemas: primeiro certo 
sentimentalismo ainda ligado ao pensamento romântico e associado à modinha e ao lundu; e o segundo, ultrapassar sua ascendência puramente burguesa e descobrir seu encontro com o "povo". Outro aspecto que incomoda Mário de Andrade é o fato de a modinha participar do âmbito da cultura popular urbana; ou seja, compartilhar de todo um modo de produção artística (publicação de partituras, presença em espetáculos pagos, entre outros) que ele considerava de modo não totalmente positivo, pois poderia interferir na criatividade e espontaneidade da criação artística. A esse âmbito da arte, Mário de Andrade denomina "semicultura" ou cultura "popularesca", ou seja, "certa música que, por sua origem e qualidade, não se encaixava perfeitamente nos universos popular e culto que eram de seu interesse" (TRAVASSSOS, 1997, p. 87).

Está longe de nossa proposta uma discussão calcada em um juízo valorativo, melhor dizendo, na qualidade ou não de uma suposta obra; mas ao contrário, sua inserção no âmbito da história e sua importância para a sociedade da época e seus desdobramentos futuros. Mas para Mário de Andrade, uma obra ligada ao mundo do entretenimento e do consumo, melhor dizendo, à incipiente indústria cultural, deveria ser vista com olhos cuidadosos. Para ele, "o artista tem só que dar pros elementos já existentes uma transposição erudita que faça da música popular, música artística, isto é: imediatamente desinteressada" (ANDRADE, 1962[1928] p. 16). Portanto, com base nas fontes orais, o artista faria a verdadeira música: a música artística. $\mathrm{E}$ a modinha, apesar de sua trajetória na história, não tem ligação direta, pelo menos em seu nascedouro, com a cultura oral.

Não obstante o debate promovido por Mário de Andrade que via na incipiente indústria cultural brasileira uma zona onde os artistas poderiam ser devorados, alguns trabalhos atuais têm observado a importância da sociedade brasileira nos grandes centros, sobretudo o Rio de Janeiro, na passagem para o século $X X$, e a importância que teve para a construção da sociedade brasileira: não enxergar nas polcas e tangos, nos maxixes e choros da virada do século, assim como em vários outros gêneros da época, como valsa, mazurca, entre outros, uma expressão verdadeira daquela sociedade; é não perceber os desdobramentos na construção da musicalidade carioca. Portanto, toda uma cultura também produzida nos centros urbanos será base para a construção de uma musicalidade "autêntica". Dizendo de outro modo, o fato de 
a música popular dos centros urbanos participarem de "sólidos esquemas produtivos profissionalizados, industrializados e comercializados (...) não quer dizer que as tradições nacionais das músicas populares se neutralizem" (DUPRAT, 2001, p. 224)

Neste sentido que o trabalho de Cacá Machado, $O$ enigma do homem célebre (2007), analisa a música de Ernesto Nazareth como um entrecruzamento entre tendências populares advindas do lundu e da polca, caminhando para o maxixe, aliado a um refinamento erudito. Enfatiza, ainda, que sua genuína produção musical é fruto de uma musicalidade complexa e resultado do entrecruzamento multicultural da época; e que esta realidade não pode ser descartada ao analisarmos ou escutarmos sua obra. E de modo algum entendemos que Mário de Andrade desvalorizava Nazareth ou os chorões cariocas do início do século XX; mas não via na música popular dos grandes centros força e, especialmente, pureza suficiente para unificar culturalmente uma nação. De qualquer forma, o choro hoje goza de grande prestígio nacional e é considerado, penso que em todo território, como um gênero que bem pode representar parte de nossa brasilidade.

Publicações posteriores como $O$ pensamento mestiço (GRUZINSKY, 2001), Hibridismo cultural (BURKE, 2003) e Culturas híbridas (CANCLINI, 2008), só para citar algumas, apesar de tratarem de época posterior aos escritos de Mário de Andrade, têm atentado para o caráter hibrido, mestiço da formação das diversas culturas. Ou seja, como as diversas sociedades, sobretudo as latino-americanas, têm formado suas identidades, mesmo culturas orais, por processos híbridos. E como culturas que consideramos tradicionais, ou tradicionalmente preservadas, estão abertas a interações interculturais e ainda como "o trabalho folclórico é "um movimento de homens de elite que, através da propaganda assídua, esforçam-se para despertar o povo e iluminá-lo em sua ignorância" (CANCLINI, p. 209). Mais à frente:

"Ao decidir que a especificidade da cultura popular reside em sua fidelidade ao passado rural, tornaram-se cegos às mudanças que a redefiniam nas sociedades industriais e urbanas. Ao atribuir-lhe uma autonomia imaginada, suprimem a possibilidade de explicar o popular pelas interações que tem com a nova cultura hegemônica." (Ibidem, p. 210)

E ainda mais à frente: 
"É possível construir uma nova perspectiva de análise do tradicional-popular levando em conta suas interações com a cultura de elite e com as indústrias culturais. (lbidem, p. 215)

O sentido que queremos destacar para a cultura popular, seja aquele dos grandes centros e, às vezes inserida numa lógica massiva e outras não ${ }^{30}$, é também seu lado dinâmico, ao lado de seus aspectos mais tradicionais. Porém, esta questão tem que ser decidida pelos próprios atores sociais em suas comunidades específicas. E estas têm que ser reconhecidas e valorizadas em suas especificidades e não colocadas numa caixa de vidro climatizada como um manuscrito faraônico que pode desintegrar-se ao mero contato com o oxigênio do exterior da pirâmide. Outro fato é que na dinâmica sócio-cultural dos grandes centros, as transformações podem ser mais velozes; mas isso pode não significar superficialidade ou descompromisso. E nesse sentido, bastariam alguns "tanguinhos" de Nazareth, ou a audição de Pelo telefone, samba ainda meio folclórico e meio maxixe (SANDRONI, 2001, pp. 118-130), ou alguns choros de Pixinguinha, para revermos a classificação de "semicultura" ou música "popularesca" efetuada por Mário de Andrade: necessitamos entender a música popular urbana, sua lógica musical, histórica e sócio-cultural, absorver seus sabores e dissabores, seus erros e acertos e, seguramente não precisamos concordar com tudo e todos. Dizendo de outro modo: nem tudo é Nazareth ou Pixinguinha; mas a fixação de um modelo interpretativo rígido e a definição de "semicultura" ou música "popularesca", sempre soará elitista, impositivo e, se aliado a um projeto nacional, ideológico; deixando pouca margem para outras construções interpretativas, para a liberdade.

Retornando à via principal, Manuel Castells, em seu livro $O$ poder da identidade (1999), propõe uma tipologia identitária tripartite que pode nos ajudar no caminho trilhado na aceitação da modinha e do lundu. Segundo o autor, "... uma vez que a construção social da identidade sempre ocorre em um contexto marcado por relações de poder, proponho uma distinção entre três formas e origens de construção de identidades (CASTELLS, 1999, p. 24):

\footnotetext{
${ }^{30} \mathrm{O}$ fenômeno da roda de samba ou das rodas de choro, que persistem na atualidade, é um fruto direto da cultura popular dos centros urbanos e não tem dependido da indústria cultural para que sobreviva, embora alguns sambistas tenham saído das mesas dos bares para as paradas de sucesso; e isso nem sempre tem sido encarado com falta de integridade por parte dos sambistas que frequentam a roda.
} 
- Identidade legitimadora: "introduzida pelas instituições dominantes da sociedade no intuito de expandir e racionalizar sua dominação em relação aos atores sociais" (Ibidem, p. 24).

- Identidade de resistência: "criada por atores que se encontram em posições/condições desvalorizadas e/ou estigmatizadas pela lógica da dominação construindo, assim, trincheiras de resistência e sobrevivência com base em princípios diferentes dos que permeiam as instituições da sociedade" (Ibidem, p. 24).

- Identidade de projeto: "quando os atores sociais, utilizando-se de qualquer tipo de material cultural ao seu alcance, constroem uma nova identidade capaz de redefinir sua posição na sociedade e, ao fazê-lo, de buscar a transformação de toda a estrutura social" (Ibidem, p. 24).

Portanto, se as identidades de resistência e de projeto, como o nome mesmo indica, estão ainda situadas um passo atrás da ideologia, ou seja, não constituem, pelo menos num primeiro momento, uma busca de estabelecimento de poder; a identidade legitimadora, pelo contrário, vai atuar dentro deste âmbito: a ideologia. E por ideologia, entendemos um discurso, idéias e crenças, modelo interpretativo ou projetos culturais, que estejam relacionados com um projeto de poder político (EALGETON, 1997, p. 39). Também, e de modo algum, queremos defender a idéia de que toda ideologia consiste de pura e simples invenção manipuladora, pois concordando com Peter Burke nem todas as tradições são inventadas (BURKE, 2008, p. 111) ${ }^{31}$. Mas o que caracteriza uma tradição (inventada ou não) como ideologia, é sua identificação com um projeto de poder, ou seja, necessita instaurar-se como um projeto político, e como sintetiza Terry Eagleton:

"O termo ideologia tem um amplo espectro de significados históricos, do sentido intratavelmente amplo de determinação social do pensamento até a idéia suspeitosamente limitada de disposição de falsas idéias no interesse direto de uma classe dominante. Com muita freqüência, refere-se aos modos como os signos, significados e valores ajudam a reproduzir um poder social dominante, mas também pode denotar qualquer conjuntura significante entre discurso e interesses políticos." (EAGLETON, 1997, P. 193).

Mas, retomando aos passos de Castells, tratava-se, num primeiro momento de legitimar a modinha como gênero autenticamente brasileiro, para num segundo, ela poder ser incluída no projeto nacionalista do grupo de Mário

\footnotetext{
${ }^{31}$ Neste aspecto, Peter BURKE, em seu O que é história cultural? 2ª ${ }^{\mathrm{a}}$. Ed. Rio de Janeiro: Jorge Zahar Editor, 2008, faz uma crítica à tese de Eric Hobsbawn exposta em seu livro $A$ invenção das Tradições. Rio de Janeiro: Paz e Terra, 2008, levantando a questão de que nem todas as tradições são inventadas.
} 
de Andrade. Estes dois primeiros passos foram efetuados já nos escritos que se iniciam em 1928, com o Ensaio sobre a música brasileira; e consumado em 1930, com a publicação de Modinhas Imperiais, onde a modinha é justificada não pela negação de características européias que a incorporam desde fins do século XVIII: "A Modinha se originou só do formulário europeu" (ANDRADE, 1980[1930], p. 7); mas e principalmente, pelo trabalho operado pelo meio, pela geografia: "A sensualidade mole, a doçura, a banalidade que lhe é própria (...) só Ihe pode provir da geografia, do clima, da alimentação" (Ibidem, p. 7). A partir desse momento, a modinha, nascida da burguesia e das classes médias do século XVIII, e que fizera parte não só da vida das "açafatas ${ }^{32}$ de corte" (ARAUJO, 1963, p. 11), mas também das escravas e escravos entre a casa grande, o terreiro e a senzala; ou nos espaços urbanos que possibilitavam uma relação intercultural, mesmo que ainda não constituída como uma democrática racial; ela, a modinha juntamente com o lundu, poderia adentrar ao projeto encabeçado por Mário de Andrade.

Além disso, mesmo na época de Modinhas Imperiais, este gênero já fazia parte da história da música luso-brasileira, e já se configurava "entre os primeiros produtos musicais brasileiros" (TRAVASSOS, 1997, p. 96). E ao analisarmos sua trajetória, vemos que sua aceitação, mesmo pelas camadas menos favorecidas, foi quase imediata, pois passa dos salões privados aos entremezes públicos e, posteriormente, às ruas em poucos anos (NERY, 2005, p. $33 ; 2007$, p. 5). Mesmo as fronteiras entre zona rural e urbana, ao atentarmos para a realidade de nossas cidades de fins do século XVIII, eram quase inexistentes. Portanto, uma inter-relação campo e cidade, não era uma irrealidade, e favorecia a troca entre uma cultura ainda "espontânea" e coletiva do mundo rural, e espetáculos teatrais já dentro de uma lógica de produção sistematizada que vinha ocorrendo nas vilas no último quartel do século XVIII.

Podemos afirmar, portanto que o projeto iniciado por Mário de Andrade não superou completamente os ideais românticos, mas deu continuidade a esta tendência pelo menos em alguns aspectos: um, a busca de heranças passadas que pudessem justificar nossa existência no presente e condicionar um projeto futuro, calcados em modelos teóricos raciais e mesológicos advindos do século

\footnotetext{
${ }^{32}$ Açafata: fidalga a serviço de damas da família real. HOUAISS, Antônio. Dicionário Houaiss da língua portuguesa. Rio de Janeiro: Objetiva, 2001.
} 
XIX, portanto ainda positivamente deterministas; outro, a continuidade de traços estéticos românticos, como o sentimentalismo (TRAVASSOS, 1997) ou a grandiloqüência de algumas obras de Villa-Lobos (CONTIER, 1985), não totalmente superados; seu apego ao nacionalismo, ligado a um projeto absolutamente novecentista e à estabilização dos estados-nações, e nesse sentido também romântico, e completamente inserido numa tendência da época. Como afirmou Eric Hobsbawm: "Se houve um momento em que o 'princípio de nacionalidade' do século XIX triunfou, esse momento foi o final da Primeira Guerra Mundial" (HOBSBAWM, 1990, p. 159).

Sua crença na pureza do folclore, outro traço romântico, hoje em dia não faz mais sentido e bastaria a célebre frase de Paulicéia Desvairada, "Sou um tupi tangendo um alaúde!" (ANDRADE, 1971), para nos recolocarmos num estado de complexidade sócio-cultural, ultrapassando o purismo e nos situando fora da tentativa de isolar o autêntico do inautêntico, e aceitar os hibridismos: nem todas as misturas são superficiais, assim como nem todas as tradições são inventadas, como mencionado acima; e, sobretudo deste lado do Atlântico. $E$ se os grandes centros são mais propícios às mestiçagens e aos hibridismos (GRUZINSKI, 2001; BURKE, 2003; CANCLINI, 2008), não significa que interações culturais não possam ocorrer (e ocorreram) de um modo verdadeiro, ou seja, como expressões autênticas dos conflitos reais vividos pelos atores sociais em sua época. Mesmo em pequenos centros ou em zonas mais afastadas; mesmo em tempos coloniais e dentro de uma sociedade ainda estamental (SOUZA, 1997; PAIVA \& ANASTASIA, 2002), as trocas interculturais foram notadas. E quando Mário de Andrade encontra traços de cultura letrada em reisados e pastoris (TRAVASSOS, 2000), isso pode não ter sido uma falsificação, mas parte de uma dinâmica cultural incontrolável; pensando-se é claro numa sociedade não estática. E como afirma Laura de Melo e Sousa "O Brasil é uma país mestiço. O futuro do mundo é a mestiçagem" (SOUZA, 2009, p. 55), em que pese ainda não termos alcançado nossa democracia social.

Por outro lado, Mário de Andrade chamou a atenção para uma produção cultural que não fazia parte do mundo da elite (as óperas e concertos) e nem do mundo do entretenimento: se por um lado, é inegavelmente ideológico querer determinar um modelo unificador para um país de dimensões tão 
grandes; por outro lado, é absolutamente humano querer que "esses Brasis" venham à baila (se reconheçam), e com toda sua riqueza; e possam fazer parte de nossa vida cotidiana, mesmo nos grandes centros. Porém, sonhar com uma comunidade nacional e querer que a imaginemos dentro dos mesmos moldes por ele imaginada (ANDERSON, 2005), deixa, seguramente, de ser um sonho; e passa a ser um projeto ideológico, portanto político. Projeto que em parte foi realizado, pois, mesmo nos tempo atuais, e quase um século depois do retorno de Graça Aranha com L'Esprit nouveau (TELES, 1972), talvez o mais caro dos presentes a Mário de Andrade, ainda estamos a discutir seus desdobramentos: seja sob um aspecto positivo ou negativo.

\subsubsection{Desdobramentos do projeto modernista}

A literatura relacionada com a modinha e lundu após 1945, e a morte de Mário de Andrade, pelo menos até a década de 1980, vai dar continuidade às orientações iniciadas pelo projeto modernista. Algumas das pesquisas irão se

preocupar como a modinha na cultura oral. Neste sentido, o livro Modinhas do Passado: cultura, folclore e música, primeiramente publicado em 1979, como o título indica enfocará processo de popularização deste gênero, ou seja, buscará no século XIX modinhas mantidas no século XX apenas na memória daqueles que a cantam, distanciando-se, muitas vezes, de sua composição original. Outros livros mais recentes, tais como Lundus e modinhas do século XIX (PEREIRA, 1981), A modinha em Vila Boa de Goiás (1982) e A modinha norte-rio-grandense (2000) mantêm essa mesma tendência.

Em 1963, aparecerá um dos principais livros sobre o assunto, A modinha e lundu no século XVIII de Mozart de Araujo. Esta publicação foi de suma importância, pois além de divulgar modinhas compostas no século anterior às modinhas da compilação de Andrade (1930), portanto pertencente a um estilo ainda não romântico, mas clássico; também identifica algumas modinhas efetuadas com base em poemas de Domingos Caldas Barbosa, o Lereno Silinuntino, associando a este não só a criação do gênero, mais sua introdução em Portugal: 
"Não desejo, porém, precipitar a afirmação, que considero a mais historicamente defensável, de haver sido Domingos Caldas Barbosa o criador e o introdutor da modinha em Portugal" (ARAUJO, 1963, p. 30).

Esta afirmação, apesar de não constituir um consenso, perdurou muito tempo no senso comum de historiadores e estudiosos da música brasileira e ainda se mantém em algum lugar. Porém, após pesquisas recentes, e como ficou discutido anteriormente, a modinha e lundu são gêneros que nascem da complexidade sócio-cultural da sociedade luso-brasileira na segunda metade do século XVIII, portanto, serão associados, evidentemente, ao processo de formação do Brasil, como estado-nação, e nesse sentido constituem uma fase do estilo de canção praticado nessa época. Porém, mais abaixo retornaremos a essa questão.

Ainda na década de 1960, mais precisamente em 1968, Gerard Behague publica o artigo Biblioteca da Ajuda (Lisbon) Mss. 1595 / 1596: Two EighteenthCentury Anonymous Collections of Modinhas, divulgando dois manuscritos: um, intitulado Modinhas (Ms. 1595) e outro Modinhas do Brasil (Ms. 1596). Na primeira coletânea, o Ms. 1595, autor descreve o que seria a modinha tipicamente portuguesa: dois sopranos em terça e às vezes sextas paralelas, acompanhamento de cravo, neste caso, quase sempre dobrando as vozes. $\mathrm{Na}$ segunda coleção, o Ms. 1596, como seriam as modinhas e lundus tipicamente brasileiros: também efetuados para dois sopranos, com acompanhamento disposto em uma única linha, à guisa de baixo contínuo, presença da síncope em muitas das peças e poemas de cunho popular. Além disso, o autor identifica na coleção dois poemas de Domingos Caldas Barbosa que serviram de texto para um lundu e uma modinha. Apesar do cunho não nacionalista, o autor tem uma preocupação bastante acentuada em identificar tipologicamente a modinha praticada na colônia brasileira.

O livro de Bruno Kiefer, A modinha e o lundu: duas raízes da música popular brasileira que teve primeira publicação no ano de 1977 refaz o caminho trilhado por Araujo para fundamentação da importância histórica dos gêneros em questão, porém chegando até o século XX. Destaca a continuidade da modinha e do lundu na obra de Barroso Neto (1981-1941), Jaime Ovale (18941955), Lorenzo Fernandez (1897-1948), Villa-Lobos (1987-1959) e Francisco Mignone (1897-1986). De qualquer modo, essas publicações ainda estão 
centradas na recomposição de certos marcos que possam fundar uma tradição da identidade brasileira, seja calcada numa cultura de tradição oral ou em recomposições históricas, se inserem ainda dentro da lógica do mito fundacional (CHAUI, 2000).

Se Mário de Andrade e seus seguidores vêem na cultura popular pertencente à tradição oral a "alma do povo", José Ramos Tinhorão foca sua análise no surgimento dos centros urbanos e potencializa sua atenção na classe média e no proletário urbano nascentes: são nessas vilas, posteriormente cidades, que surge um novo tipo de classe social, a classe média urbana, os futuros trabalhadores do comércio, funcionários públicos, barbeiros, etc. E, tanto a modinha quanto o lundu, tornar-se-ão veículos autênticos dessa nova classe, e expressarão, ao longo dos anos vindouros, seus anseios artístico-sociais.

José Ramos Tinhorão, ao longo dos vários anos, vem se dedicando à pesquisa da modinha e do lundu; muitas vezes inserindo o tema em capítulos. Das muitas obras que publicou destacamos: Pequena história da música popular (1991[1974]), História social da música popular brasileira (1998), Os sons dos negros no Brasil (2008]1998]) e Domingos Caladas Barbosa: o poeta da viola, da modinha e do lundu (2004). Nestas publicações, o autor tem insistido na origem popular urbana não só do lundu, mas também da modinha e, assumindo a linha de pensamento de Araujo que também defende Domingos Caldas Barbosa como o criador e divulgador desses gêneros em Portugal. Porém, diferentemente de Andrade que vê no folclore a alma do povo, Tinhorão interpreta os gêneros em questão como manifestações musicais das camadas sociais populares urbanas já em crescimento na colônia:

\footnotetext{
"Assim, se a partir de 1775 Caldas Barbosa já aparece cantando suas modinhas em Lisboa, tais canções só podiam constituir autêntica música popular da colônia, o que por sinal o francês Link testemunha nas anotações de sua viagem a Portugal, de 1797 a 1799" (TINHÕRAO, 1991[1974], p. 15)

E numa publicação mais recente:

"[o] novo gênero de canção urbana que, levado da colônia do Brasil para os salões lisboetas pelo mulato Domingos Caldas Barbosa" (TINHORÃO, 2004, p. 102).
} 
Mário de Andrade, portanto, ao destacar a origem aristocrática e burguesa da modinha, somente a aceita por ter absorvido, ao longo de sua história, certa brasilidade advinda do clima, da geografia e da alimentação e também por adentrar a história da expressividade musical brasileira. Ramos Tinhorão, ao contrário, ao interpretar a modinha, e também o lundu, como autênticas expressões de uma nascente classe popular urbana em fins do século XVIII, atribui a estes gêneros verdadeiras posições de destaque na história da música popular, na vida social da época, justificando inclusive, nossa musicalidade atual com base nessa tradição.

Já a sua tese de que a modinha e o lundu foram criados pelo padre mulato Domingos Caldas Barbosa, merece ressalvas: a modinha e lundu, como vimos discutindo, são criações genuínas da complexidade sócio-cultural de fins do século XVIII. Tinhorão observa muito bem este fato, destacando essa complexidade no mundo luso-brasileiro e que como a modinha, canção de amor por excelência e o lundu, canção erótico-satírica da época, vão servir de veículos para a sociedade em questão. Como o nosso Lereno, que nasce na colônia e vai para Lisboa em 1763 onde viveu até o final de sua vida, portanto também o Lereno deles, foi um personagem que soube transitar nessa sociedade em transformação - primeiramente por mãos do Marquês de Pombal e posteriormente no período da "Viradeira" - e colher os frutos de uma época que, apesar de monárquica, está absorvendo, mesmo que paulatinamente os ares da ilustração. Portanto, enfatizamos: a modinha e o lundu serão gêneros autênticos daquela época e da sociedade que se formava, e Caldas Barbosa soube seguramente negociar com seu tempo. Nas palavras de Machado Neto:

"A modinha seria fruto, então, dessa articulação das novas formas de sociabilização. O fundamento de sua existência esta na ampliação das fronteiras de sociabilização entre as classes, formando conjunturas que quebravam, agora mais intensamente, os rígidos códigos protocolares do sistema autocrático antigo" (NETO, 2008, p. 334).

E mais à frente:

"Ademais, a canção urbana espalhou-se sem distinção de classes. Realeza, nobreza e burguesia a reconheciam como expressão unívoca dos seus salões: as açafatas da Rainha Dona Maria a praticavam sob a tutela de frades palacianos" (Ibidem, p. 347). 
O que estamos defendendo, juntamente com Machado Neto, é que tanto a modinha quanto o lundu, pertenciam a essa época, ou seja, à sociedade, à historia, e foram incluídos dentro do projeto civilizador ilustrado iniciado por Pombal e que teve continuidade na "Viradeira". Por outro lado, ao inserir em seus poemas vocábulos ligados à cultura popular da colônia e, supomos, ao sincopar algumas melodias, Domingos Caldas Barbosa, deu sua valiosa contribuição, sobretudo por expressar valores mestiços incorporados a esses gêneros e que serão reconhecidos como brasileiros. Se num futuro não muito distante, estes gêneros farão parte de duas nações independentes, isso também faz parte de nosso passado histórico absolutamente ligado à história lusitana e às tendências sócio-culturais da segunda metade do século XVIII vigente nessa época. Neste caso, uma disputa pela paternidade dos gêneros em questão, estaria ainda dentro de um projeto nacionalista, desta feita baseado num determinismo calcado no mito da origem, fundacional, e que possa justificar nossa autonomia histórico-sócio-cultural no presente; mas ainda uma discussão determinista.

\subsubsection{Rumo à ultrapassagem do romantismo}

Após a década de 1980, uma série de publicações, das quais destacamos Modinhas luso-brasileiras (DODERER, 1984), Modinhas, lundus e cançonetas (MORAIS, 2000), As modinhas do Brasil (LIMA, 2001), Muzica escolhida da viola de Lereno (BARBOSA, 2003), Para uma história do fado (NERY, 2005), além de artigos que serão dedicados ao tema, dos quais destacamos Joaquim Manuel (FAGERLANDE, 2008), estarão preocupados com o entendimento da complexa sociedade, após a segunda metade do

século XVIII, suas conseqüências no futuro do mundo luso-brasileiro, 0 surgimento da modinha e do lundu e seus desdobramentos na formação da cultura musical brasileira; mas sem preocupações nacionalistas.

Algumas publicações como $A$ música na corte de $D$. João VI (CARDOSO, 2008), A construção do gosto: música e sociedade no Rio de Janeiro - 1808-1821 (MONTEIRO, 2008) e Castrati e outros virtuoses (PACHECO, 2008), incluem capítulos ou trechos de capítulos que abordam a 
modinha e o lundu como parte da musicalidade e estilos praticados na época e, portanto, como gêneros ligados a tendências históricas e sociais do projeto luso-brasileiro nestas terras. Neste sentido, a excelente síntese efetuada por Diósnio Machado Neto, A modinha nas sendas das reformas iluministas (2008), interpreta a modinha, juntamente com a ópera em fins do século XVIII, como dois pólos do mesmo projeto civilizador iluminista: um público, exercido nos teatros, na platéia, nas frisas e camarotes; outro, na sociabilidade dos salões privados, onde as moças podiam exercer seus dotes femininos para a pequena sociedade de seu convívio. Mas não é só isso, a popularização da modinha e do lundu, (NERY 2005, 2007; MORAIS, in BARBOSA, 2003), representaria a introjeção desse modus vivendi, não sem adaptações e licenças; mesmo que esses desvios não chegassem a comprometer a ideologia ilustrada perpassada no estilo sensível da melodia, no conteúdo dos poemas, e na tentativa de domar as licenças dos lascivos lundus.

Quanto ao controle da "moral desregrada" (MACHADO NETO, 2008, p. 330) que perpassava nas diversas festas populares e, sobretudo, na dança do lundu fora dos salões já aristocraticamente climatizados, parece que não foi tão eficaz para as camadas mias populares. Pois, como vimos nos escritos de A.P.D.G. (Cf. cap. 1), o lundu será estilizado nos salões das classes mais abastadas, mas não quando dançado pelas classes menos privilegiadas, ou dito de outro modo, pelos negros e mestiços.

Não discordamos da interpretação ideológica do "embranquecimento" do lundu (NETO, 2008, p. 331), ou melhor, da minimização das raízes culturais negras na produção cultural de fins do século XVIII e durante o século XIX, defendida por Machado Neto; mas o sincretismo que continuará ocorrendo e será alvo, por exemplo, das críticas ao maxixe, a "dança excomungada" (EFEGÊ, 1974) na virada do século XIX para o XX, ou seja, um século à frente. Portanto, o controle ideológico ocorreu e em grande parte somos frutos dessa ilustração perpassada nos modelos de sociabilidade via modinha e lundu; mas as suas sombras não foram cem por cento eficazes deste lado do Atlântico: pois, se por um momento ofuscou o brilho do lundu dançado e cantado nos salões cortesãos pela burguesia e pelas classes médias mais abastadas; nos terreiros e nos largos, como observou o "tímido" cronista A.P.D.G., continuou a exercitar sua lascívia primitiva e instintiva de modo radiante, o que vai gerar 
com o passar dos tempos, não sem dificuldades e conflitos, muitas discussões e mestiçagens musicais, como por exemplo, o maxixe destacados nos escrito de Jota Efegê $(1974)^{33}$.

A independência brasileira será, indubitavelmente, um capítulo importante em nossa história; e dependerá, evidentemente, da dinâmica da sociedade luso-brasileira dos primeiros séculos de colonização. Mas, não nos enganemos, o projeto lusitano não era criar deste lado do Atlântico uma sociedade com fisionomia distinta. Porém, as concessões administrativas e as negociações com os comerciantes locais (SOUZA, 2006; RUSSELL-WOOD, 2000), o afrouxamento do estanco da música e das exigências de pureza de sangue (NETO, 2008) e, consequentemente, a criação de condições de uma sociabilidade menos rígida, vai aos poucos despertando uma consciência para a diferença, para uma alteridade (NOVAIS, 2005; PAIVA, 2002): somos ainda lusos, mas deste lado do Atlântico Sul; e estamos nos tornando lusos diversos. Porém, isso ainda não vai se traduzir em uma consciência que resulte numa luta pela independência política; mas resultou na elaboração de um gênero musical diverso, o lundu, que foi forjado em fornos mestiços, quase impossíveis de se malhar pela dificuldade de suas altas temperaturas, e numa negociação constante com o projeto civilizador lusitano, ou seja, Europeu. Por sua vez, a emancipação política só ocorreria alguns anos mais tarde, em 1822, um ano após o retorno da Família Real: mas ainda atrelada à continuidade do sistema monárquico escravista, impossibilitando a cidadania do negro e, conseqüentemente, sua emancipação política, dificultando sobremaneira suas lutas por vias legais; e ainda dirigido por um monarca português.

\subsection{A modinha e o lundu: 50 anos de registros musicais}

\subsubsection{Romantismo: a imagem sonora do amor brasileiro}

O LP Modinhas fora de moda foi um dos primeiros registros sonoros contendo modinhas e lundus dos séculos XIX e XX, datado do final da década

\footnotetext{
${ }^{33} \mathrm{O}$ maxixe, o choro, o samba, para citarmos gêneros musicais relacionados com a cultura negra em fins do século XIX e início do XX. Também os batuques, ainda em voga no interior de São Paulo e Minas Gerais; também o jongo, em algumas cidades paulistas da zona rural, entre tantas manifestações que seriam construídas pela necessidade, insistência e resistência da cultura negra no Brasil que em parte, não totalmente "domada" pela cultura ilustrada, de raciocínio lógico e geométrico.
} 


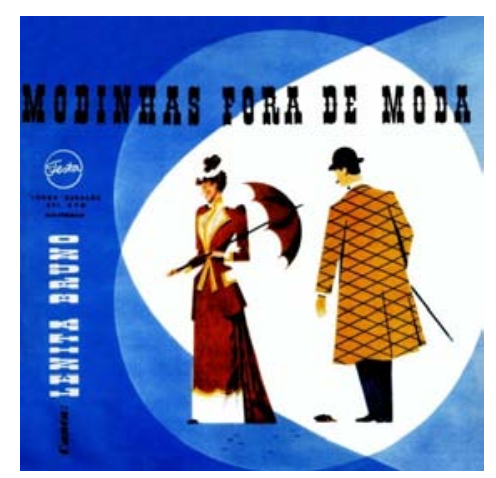

de 1950, portanto há mais de cinquenta anos atrás e ainda disponível no mercado em formato compact disc devidamente remasterizado. Nessa coletânea foram gravadas doze modinhas e um lundu de autores diversos, interpretados pelo soprano Lenita Bruno acompanhada por uma orquestra com arranjos orquestrais e regência do maestro Léo Peracchi. As modinhas do século XIX registradas nesse LP, Se os meus suspiros pudessem e Casinha pequenina (domínio público), Hei de amar-te até morrer e Róseas flores da alvorada, foram publicadas no livro de Mário de Andrade (1980[1930]) como sendo de autores anônimos do século XIX. Canções de autores consagrados, como Cantiga, 1a. e 2a. Trovas de Alberto Nepomuceno, Canção da felicidade e Cantiga de Barroso Neto, Lundu da marquesa de Santos de H. Villa-Lobos, Foi numa noite calmosa de Luciano Gallet e Modinha de Jaime Ovale.

Portanto, é um registro que embora enfatize compositores consagrados na história da música brasileira, procura dar conta do conceito de modinha vigente naquela época, qual seja, o de canção de cunho romântico, entendendo com esse conceito não apenas seu conteúdo poético amoroso, mas o compromisso com a estética romântica, compreendida como um etilo que vigorou, grosso modo, após o primeiro quartel do século XIX e primeiros anos do século XX. Também a inclusão das modinhas Se os meus suspiros pudessem e Casinha pequenina, ambas de domínio público faziam parte desse registro. Neste aspecto, o Lundu da Marquesa de Santos, apesar do título enfatizar seu gênero, pelo caráter de seu texto e opção de andamento, está mais próximo de modinha. O lundu nesta peça está caracterizado no sincopado da melodia e, sobretudo em seu acompanhamento à guisa de habanera. Outro aspecto muito caro aos lundus do final do século XVIII e do século XIX, os trocadilhos e insinuações eróticas, e seu caráter jocoso, insinuações do mundo negro, não se encontram presentes nesta peça (LIMA, 2006; MORAIS, 2000; TINHORÃO, 1998). Em concordância com Mozart de Araújo e numa referência analítica ás modinhas do final do século XVIII, o Lundu da Marquesa de Santos bem poderia ser caracterizado como um gênero híbrido:

"Nascidos de berços opostos - ela, açafata de Corte e ele, moleque de eito Modinha e Lundu, a despeito desse antagonismo social de origem apresentam 
conexões históricas tão estreitas e cresceram numa convivência tão íntima dentro da 'sociedade' brasileira que, em determinados momentos e principalmente na última década de setecentos, pude encontrar modas ou modinhas que são quase lundus. E lundus que são quase modas ou modinhas" (ARAUJO, 1963: 11).

Se olharmos, mesmo que de maneira superficial, os manuscritos da Biblioteca da Ajuda, intitulados Modinhas do Brasil (LIMA, 2001), facilmente entenderemos a questão levantada por Mozart de Araújo. Neste conjunto de peças, tendências que são atribuídas ao lundu (tais como a presença da síncope e frases compostas de pequenos fragmentos motívicos, por exemplo), serão encontradas também nas peças classificadas como modinhas. Porém, reservaremos as discussões relacionadas a essa questão para o capítulo 5: 0 estilo clássico nos trópicos.

Mas, retornando as discussões sobre o vinil Modinhas fora de moda, e sem a intenção de iniciar um debate para destacar o que estaria em moda na virada da década de 1950 para 1960, gostaria de destacar que as modinhas, segundo o título do álbum, já estariam, nessa época, fora de moda. Portanto, o registro também tem um papel pedagógico: recolocar a modinha no cenário da interpretação da música brasileira; e, evidentemente, reconstruir o sentido histórico da formação da canção de amor brasileira. Os arranjos, a escolha dos timbres e opções harmônicas, procuram caracterizar um estilo romantizado, melancólico, com uso de timbres escuros e interpretações lentas e um pouco sofridas. O canto serve-se de portamentos, diminuendos e ralentandos, apesar de serem efetuados de modo discreto e os contrastes, por sua vez também são efetuados com muito equilíbrio e sutileza.

Já o registro realizado pelo soprano Léa Vinocur Freitag acompanhada da pianista Maria do Carmo Arruda Botelho em 1967, Modinhas coloniais e imperiais, inclui obras compostas anteriormente ao século XIX, ou seja, peças do século XVIII, portanto, ainda pertencentes a uma época onde vigia o estilo clássico. Não obstante esta questão, que não tem implicação apenas cronológica, mas também estilística, as interpretações também tendem para o estilo romântico, tanto das peças do século XIX quanto as dos setecentos. E por romantismo, entendemos a prática interpretativa vigente após os primeiros trinta anos do século XIX e perdurando, pelo menos, até a primeira década do século $X X$. No que tange a questão vocal, o que mais nos interessa em sua 
opção interpretativa, além de portamentos e do uso mais intenso do vibrato incorporado à emissão vocal e não utilizado como um ornamento, é o fato privilegiar os timbres escuros; ao contrário do modelo vigente durante o século XVIII e início do XIX, em que há uma preferência pela voz clara e ágil (PACHECO, 2006 e 2008)

Apesar da publicação do livro de Mozart de Araújo ser datado de 1963, A modinha e o lundu no século XVIII, e como o próprio título indica, têm como objetivo o resgate desses dois gêneros em um tempo mais recuado; gravações posteriores, como Modinhas coloniais e imperiais, insistirão em um compromisso com o estilo romântico de interpretação. Ou seja, parece que há uma concepção romântica enraizada, consciente ou inconscientemente, no estilo de performance ligados à modinha e ao lundu. De qualquer modo, o livro de Mozart de Araujo, concentra-se em discutir a época de surgimento dos gêneros em questão, bem como sua origem; e não atenta para questões relacionadas ao estilo interpretativo e sua vinculação com períodos musicais.

Porém, retornando à questão da performance, tema bastante em voga no Brasil ainda nos dias de hoje, inclusive nos meios acadêmicos. De qualquer modo, poderíamos dizer que esta discussão tem uma longa história, e remonta pelo menos ao início do século XX, sobretudo se levarmos em conta o livro de Arnold Dolmetsch (1915), um dos pioneiros no resgate e sistematização de certos procedimentos interpretativos dos séculos XVII e XVIII, baseando-se em tratados de época, fac-símiles e edições príncipes (AUGUSTIN, 1999: 16). Depois de Dolmetsch, seguiram-se outras publicações e, evidentemente, o surgimento de instrumentistas e grupos especializados foi quase uma decorrência natural do interesse pela música antiga, sobretudo a renascentista e barroca, na virada do século XIX para o XX; além disso, o interesse de editoras em publicar partituras, tal como a Schot, que inicia sua coleção de música barroca já em 1933, também não tardaria (Idem, 1999: 19).

Mas retornando ao nosso foco, apesar das críticas dos pioneiros da Semana de Arte Moderna ao sentimentalismo e à afetação romântica, do pioneirismo do Conjunto de Música Antiga da Rádio MEC em 1957 e do trabalho efetuado na década de 1940 por Hans-Joachim Koellreutter e de Roberto de Regina, preocupados com a interpretação da música dos séculos XVII e XVIII (AUGUSTIN, 1999: 42-43); tendências romantizadas persistem na 
estética modernista (Cf. VOLPE, 2010; TRAVASSOS, 2000; CONTIER, 1985);

e também nas interpretações das modinhas e lundus, mesmo que algumas obras gravadas em vinil tenham sido compostas no século XVIII, portanto, ainda pertencentes ao que se denomina Período Clássico e, portanto, dentro de modelos interpretativos anteriores ao do romantismo musical. Nesse sentido, os registros de modinhas e lundus anteriores da década de 1980, vão dar continuidade, em certo aspecto, à herança romântica que persiste no século XX, uma das facetas que persiste dentro da estética do modernismo.

\subsubsection{Modinha, lundu e folclore: as raízes do Brasil?}

O conceito de nação associado a questões raciais nasce durante o século XIX e está ligado a dois fatores essenciais: a geografia ou meio, como um dos fatores determinantes para convivência e construção de traços identitários sólidos. Os partidários desta interpretação, "advogam a tese de que o desenvolvimento cultural de uma nação seria totalmente condicionado pelo meio" (TRAVASSSOS, 1993: 58); e o problema da raça, "que além de sua definição biológica acabou recebendo uma interpretação sobretudo social" (Idem, 1993: 17). Ambas as correntes, estão ligadas às tendências positivistas e, portanto deterministas, que adentram o pensamento antropológico após a segunda metade do século XIX tanto na Europa quanto no Brasil. Mário de Andrade, mesmo escrevendo na segunda década do século $X X$, mas ainda baseado nos mesmos pressupostos, pôde afirmar que indecisões de raça nos levam a indecisões artísticas (Cf. p. 88), dentro de uma interpretação completamente identificada com as teorias raciais do século XIX. Um pouco mais tarde, em 1930, ano da publicação de Modinhas Imperiais, portanto somente dois anos depois da publicação de Ensaio sobre na música brasileira, de 1928, Mário de Andrade efetua uma afirmação completamente mesologista, atrelando características da modinha, ou da música brasileira, tais como a sensualidade, a doçura e a banalidade, à geografia, ao clima e a alimentação (Cf. p. 88).

Assim sendo, a busca por um Brasil politicamente independente, passava também pela busca de um Brasil culturalmente independente, que 
sintetizasse, ou melhor, criasse seus próprios modos de expressão artística; e a chave mestra para isto, segundo Mário de Andrade, eram os parâmetros de raça e meio, apoiado nas teorias advindas do século anterior, e como afirma Maria Alice Volpe:

"Desde as últimas décadas do séc. XIX e as primeiras décadas do séc. $\mathrm{XX}$, as concepções de identidade nacional estavam fundamentadas nas teorias de formação do "caráter nacional" brasileiro, especialmente segundo as reinterpretações irradiadas da Escola do Recife, também chamada "geração de 1870". Polarizavam-se aí dois parâmetros conformativos - raça e meio segundo a influência das teorias cientificistas" (VOLPE, 2010, p. 3)

E a fundação para essa construção, o substrato para nossa independência artístico-cultural, segundo esse modelo e não só na terra do pau-brasil, era o folclore: somente quando o músico brasileiro tiver abosorvido a musicalidade popular, entendida como folclórica (uma espécie de "inconsciente coletivo" calcado em "uma comunidade nacional" - TRAVASSOS, 2000: 39), os compositores produzirão arte nacional.

Com a publicação do Ensaio sobre a música brasileira em 1928, e posteriormente Modinhas Imperiais em 1930, a tendência por identificar o Brasil com a cultura popular, não foi pequena. Aliás, essa tendência já havia iniciado nos últimos anos do século XIX, sobretudo com as publicações de Silvio Romero, como Folclore brasileiro: cantos Populares do Brasil (1893) e História da Literatura (1888), isso para nos atermos a livros que incluem a música como um fator determinante na formação cultural de uma nação. De qualquer modo, a tendência de buscar na cultura popular de tradição oral as raízes de uma nação, tem origem no século XVIII com o pensamento iluminista; mas somente no século XIX o estudo do folclore passa a ser tratado como uma herança passada e relacionado com a construção de autonomia nacional (ORTIZ, 1992, p. 66)

Com base nessas idéias (raça, meio e folclore) alguns autores começam a buscar nas culturas populares, especialmente aquelas mais distantes dos centros urbanos, melodias que possam ser classificadas como modinha ou lundu. Ou seja, foram buscar a modinha e o lundu já devidamente inspirados na cultura oral, portanto, com assinatura de reconhecimento de cultura "genuinamente" nacional. Foi, portanto, com base nessa tendência que surgiu o livro Modinhas do Passado: cultura, folclore, música, de Batista Siqueira (1979 
[1957]). O livro, como o subtítulo indica, tem como objetivo uma discussão que busca capturar a modinha dentro da tradição oral. Após essa publicação, outras se seguiram, tais como: Lundus e modinhas antigas (PEDREIRA, 1981), A modinha em Vila boa de Goiás (RODRIGUES, 1982), Raízes da música popular brasileira (VASCONCELOS, 1991), A modinha norte-rio-grandense (GALVÃO, 2000). Evidentemente que temos outras publicações que incluem os gêneros em questão em seus conteúdos, porém citamos somente alguns livros preocupados em localizar a modinha e lundu como tema central na cultura popular de tradição oral.

Entretanto, o que destacamos neste capítulo é a identificação efetuada por Siqueira de algumas modinhas, outrora autorais, que reapareceram no seio da cultura popular anônima, folclorizadas, dentre as quais destacamos a modinha Se os meus suspiros pudessem (SIQUEIRA, ob. cit. p.158). A partir dessa pesquisa pudemos conhecer uma das versões desta modinha que foi utilizada no registro do álbum Modinhas fora de moda (1958). A música recolhida por Siqueira é totalmente diversa da partitura publicada por Gerard Doderer em seu livro Modinhas luso-brasileiras (1984: 102). Portanto, o autor dá uma resposta à indagação de Mário de Andrade efetuada em Modinhas Imperiais: "Ora dar-se-á o caso absolutamente raríssimo duma forma erudita haver passado a popular? (ANDRADE, 1985[1930]: 8). As pesquisas de Siqueira nos dizem que sim!

Como acenado acima, as duas versões diferem bastante: a primeira, recolhida por Siqueira como domínio publico, está em compasso 6/8 e na tonalidade de ré menor; tem melodia bastante simples e completamente silábica, não apresentando grandes dificuldades técnico-musicais; já a que consta da publicação de Doderer, está na tonalidade de sol maior e compasso $4 / 4$, apresenta grande profusão de ornamentos. Siqueira destaca que essa modinha foi cantada pela mulata Vidinha no romance, Memórias de um sargento de milícias, de Manuel Antônio de Almeida (1831-1861) publicado entre os anos de 1852-3 em forma de folhetim. Não sabemos, de fato, qual das duas versões Vidinha teria cantado e encantado o coração do meirinho Leonardo, protagonista do romance. $O$ fato é que uma delas tornou-se folclórica e adentrou a história da música também pela tradição oral; além de fazer parte da história da literatura. Muitas outras modinhas que tiveram 
publicação nos séculos XIX e início do XX serão recolhidas na "boca do povo" e comentadas por Siqueira em seu livro. Porém, Se os meus suspiros pudessem, será a pedra de toque das discussões e a que receberá várias gravações.

Temos, portanto, a partir da década de 1920, uma tendência que se refletirá também nos registros sonoros, e não apenas ligadas às pesquisas de arquivo; mas preocupada em associar a modinha com a música folclórica. E o registro desta modinha não só por Lenita Bruno e posteriormente por Andréa Daltro no CD Modinhas Brasileiras (1997); o registro de Casinha Pequenina no LP Cantares (1977); e também a gravação de Quando as glórias que gozei, efetuada por Antônio Nóbrega em Madeira que cuim não rói (1997), buscam essa identificação: herança folclórica e construção de uma identidade nacional. De qualquer modo, essa identificação vai conferir a interpretação musical, evidentemente, uma postura que leve em conta fatores ligados a essa manifestação, tais como, certa espontaneidade e simplicidade. E, de fato, essa tendência se chocará com o bell cantismo de modinhas do nosso período romântico em que ainda persiste certo virtuosismo vocal, muito próximo de um estilo de Rossini e Belline (PACHECO, 2008) e ainda muito ligadas às camadas sociais média e alta, um dos pontos em que Mário de Andrade aponta sua crítica antieuropéia.

SE OS MEUS SUSPIROS PUDESSEM...*

(Sécuio XVIII)

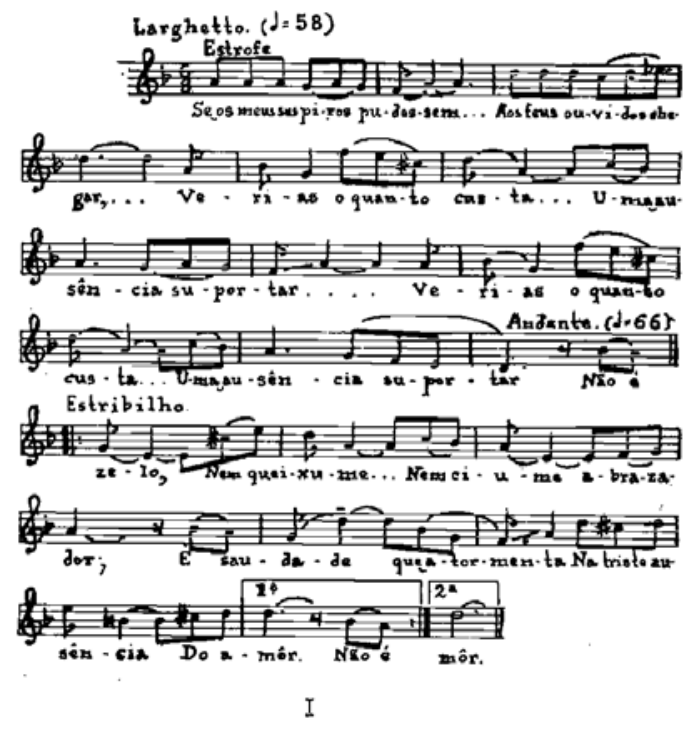

Se os meus suspiros pudessem (SIQUEIRA, 1979[1957]) 

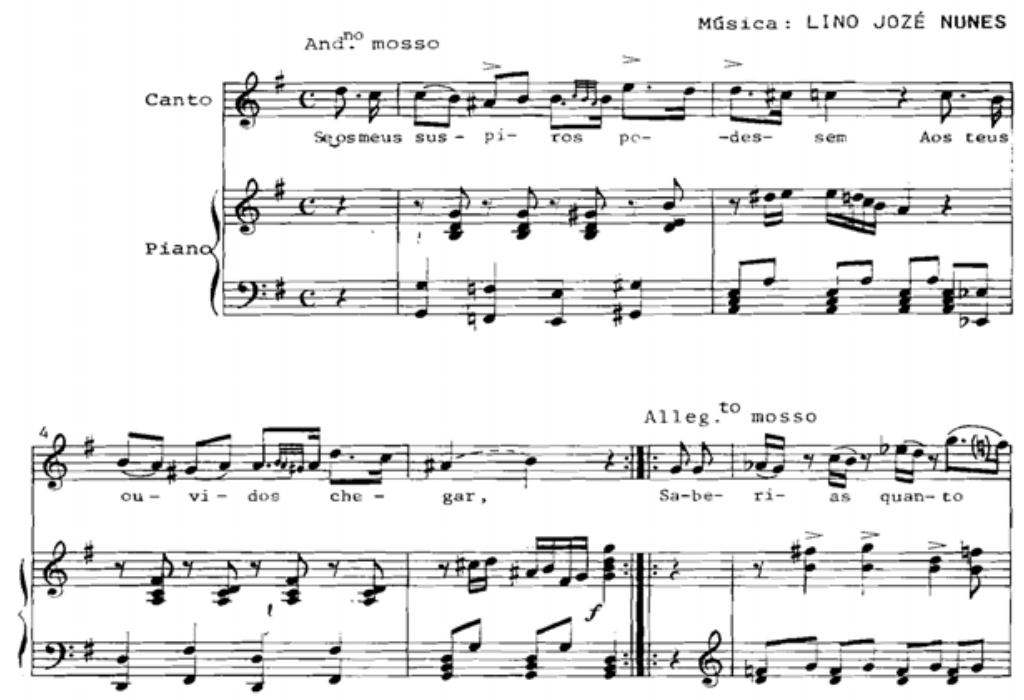

Se os meus suspiros pudessem (DODERER, 1984)

\subsubsection{Modinha, lundu e música popular urbana}

Outra vertente que norteou os registros da modinha e do lundu ao longo dos últimos quarenta anos foi uma aproximação com a música popular produzida nos centros urbanos atuais. Evidentemente, que as discussões levantadas por José Ramos Tinhorão em seu livro História da música popular brasileira (1998), contribuíram de modo fundamental para uma aproximação entre os gêneros em questão e a lógica do entretenimento nos centros urbanos. E ao observarmos o contexto de surgimento da modinha e do lundu, não é difícil perceber que foram amparados, já em fins do século XVIII, por um aparato vinculado não só ao incipiente mercado editorial da época como ao mercado de entretenimento, levando em consideração, evidentemente, sua entrada como entremez, nos espetáculos teatrais da época; além das aulas particulares de canto e instrumento efetuadas por professores de música às senhoras e senhoritas pertencentes às classes mais elevadas.

E nesse sentido, a criação do Jornal de Modinhas, com veiculação quinzenal entre os anos de 1792 e 1796 e que tinha como objetivo apresentar 
uma nova modinha ${ }^{34}$ a cada publicação; e também a publicação, em 1801, do Jornal de modinhas novas dedicadas às senhoras, além do sentido da publicação periódica, propunham-se atingir um público alvo específico. No século XIX, com a vinda da Família Real após 1808, as publicações serão iniciadas deste lado do atlântico, além de todo um aparato, como inauguração de teatros, uns dedicados às camadas mais abastadas, outros às menos favorecidas; também o incremento considerável no contingente da orquestra e coro ligados a Capela Real. Além disso, a veiculação de lundus e modinhas como entremez em espetáculos públicos (óperas, peças teatrais), como destacado acima, impulsionaram ainda mais a produção desses gêneros ${ }^{35} \mathrm{e}$ deram seguramente um impulso ainda maior à sua popularização, atrelados inicialmente, às manifestações espontâneas nos largos e terreiros, no caso dos lundus; ou aos salões privados, quando praticados pela corte, classe média e burguesia da época.

Todo esse aparato (teatros, publicações, aulas particulares e mesmo as festas oficiais), servirá de veículo para a divulgação de um modelo de entretenimento em fins do século XVIII e início do XIX e dará um impulso grande para o que entendemos hoje como cultura urbana. Nesse sentido, uma aproximação da modinha e do lundu com a lógica da cultura popular urbana nos dias de hoje é muito sugestiva. Porém, antes de tomarmos decisões que incidam diretamente sobre questões estilístico-musicais, precisamos entender a musicalidade que esses gêneros encerram e, consequentemente, quais são suas peculiaridades estilísticas.

Vários foram os registros que buscaram, na atualidade, esta tendência por "atualizar" a modinha e o lundu: ou seja, efetuar interpretações musicais nas quais peças do passado se revistam de uma roupagem mais próxima da sonoridade atual. Dentre eles, citamos o álbum duplo Cantares (1977), com arranjos dos maestros Léo Peracchi e Radamés Gnatalli, onde músicos de linhagem erudita e popular se encontram na interpretação de modinhas e lundus do século XIX até canções do XX, procurando traçar uma linha evolutiva

\footnotetext{
${ }^{34}$ Modinha, nesse contexto, tem sentido de canção ou cantiga, ou seja, música para ser cantada; neste sentido, mesmo um lundu poderia ser veiculado no periódico.

35 Nesse aspecto, o estudo de Macelo Fagerlande, Joaquim Manoel, Improvisador de modinhas (Brasiliana, no. 27 - 2008) é esclarecedor ao reconstruir parte da vida desse músico brasileiro em Lisboa, como aventa a hipótese, bastante segura, de que um dos impulsos para que viajasse à Portugal, teria sido a produção de modinhas e lundus para espetáculos teatrais (entremezes).
} 
direta.

Também o vinil Modinha e lundu - Bahia musical, séc. XVIII e XIX, dirigido por Manuel Veiga e registrado na década de 1980, busca uma atualização na sonoridade dos lundus e modinhas, mas com bastante discrição. Mais adiante, Manuel Veiga dirige o CD da cantora Andréa Daltro, Modinhas Brasileiras - songs from 19th century Brazil (1997). Nestes registros, apesar da instrumentação discreta, à guisa de música de câmara, a interpretação da cantora, com voz não empostada, busca claramente uma ligação com a sonoridade atual; enquanto a parte instrumental, respeitando as partituras originais, nos remetem as serestas do século $\mathrm{XIX}^{36}$.

O CD Sementes do fado (2006), registrado em Lisboa pelo grupo Os músicos do Tejo, busca interpretar modinhas do século XVIII e início do XIX aproximando-se do estilo da época, mais leve e menos afetado, mas com o sotaque do fado atual: o canto é empostado e dentro de um estilo erudito, porém leve, claro e ágil; mas o cravo e a guitarra portuguesa buscam articulações, sobretudo nas peças cantadas, que reconhecemos nos fados de nosso tempo. Evidentemente que nossa intenção não é, de modo algum, passar a alimpo todos os registros até então conhecidos, mas colocar em evidência tendências interpretativas da modinha e do lundu que buscam, de certo modo, uma atualização estilística, um modo de interpretação que busque alguma conexão com tendências atuais, e não somente passadas.

\subsubsection{O movimento da música antiga e a música colonial: barroquismo versus classicismo}

Nos últimos anos, a música luso-brasileira produzida entre o século XVIII e primeiro quartel do século XIX, tem despertado o interesse de um movimento que vem se auto-determinando "performance historicamente informada"37. Ou seja, os registros ligados ao resgate do que se convencionou chamar música colonial, aquela efetuada antes da independência do Brasil, portanto anterior a

\footnotetext{
${ }^{36}$ Outros registros, tais como O ipê e você - trovas, efetuado por Luiza Sawaia e Achile Pichi (Portugal: 2005), onde buscam efetuar harmonizações que seguem tendências modernas, como uso de dissonâncias como parte integrante do acorde, tonalidade expandida, politonalidade, entre outras técnicas.

${ }^{37}$ Vamos debater esse conceito no sub-capítulo: História e interpretação.
} 
1822, tem sido realizados também por aqueles que perseguem esses ideais interpretativos.

O movimento da performance histórica ${ }^{38}$, conforme a classificação de Joseph Kerman (1987) sobre a música anterior ao que se convencionou chamar de período clássico no continente europeu, floresceu após a virada para o século XX. A partir da publicação, em 1915, do livro The Interpretation of the Music $f$ the 17th and 18th centuries de Arnold Dolmetsch ${ }^{39}$, que teve como meta musical resgatar padrões interpretativos que foram sendo deixados de lado a partir do século XVIII, com o advento da musica sinfônica e, sobretudo durante o século XIX, após a mudança para uma estética romântica. Para este fim, Dolmetsch voltou suas pesquisas tanto para as partituras originais (manuscritos e fac-símiles das primeiras edições), para os tratados de época, como também para a construção de instrumentos que foram usados na ocasião das performances no passado.

A meta de Dolmetsch, e daqueles que posteriormente deram continuidade às suas pesquisas, era a "reconstrução" do ambiente sonoro em que consideravam que as obras foram criadas e apresentadas no passado:

"Toda essa música, de acordo com a doutrina musicológica, deve ser apresentada - na medida do possível - de acordo com as tradições da execução reconstituída e com as condições de seu próprio tempo e lugar" (KERMAN,1987: 258).

E continua:

"No período do pós-guerra, a execução da música antiga, tal como a música de vanguarda, foi uma atividade vital e inovadora." (ibidem: 258)

Evidentemente a musicologia que havia se iniciado e se desenvolvido durante o século XIX, deu suporte teórico para que as pesquisas caminhassem nessa direção. E como tão bem sintetizou Joseph Kerman, "era evidente que a musicologia não parasse só na teoria, mas atentasse também para a performance" (KERMAN, 1987). Portanto, e sempre concordando com Kerman, esse movimento em direção ao passado foi pelo menos no início, o resultado de uma grande mudança na concepção do modelo de interpretação da música;

\footnotetext{
${ }^{38}$ Adotamos a nomenclatura de Joseph Kerman utilizada no texto O movimento da performance histórica (KERMAN, J. Musicologia. São Paulo: Martins Fontes, 1987.

39 Hoje, todo o período clássico e mesmo o romantismo da primeira metade do século XIX tem sido foco desta corrente (KERMAN, 1987)
} 
foi, pelo menos em um aspecto, uma tentativa de construção de outro modelo interpretativo na música antiga, que se distanciasse dos padrões românticos ainda vigentes.

Nos Estados Unidos da América, esses ventos não tardariam em atravessar o oceano, sobretudo se levarmos em conta que o início do século seria abalado por duas grandes guerras, e que estes eventos, de não pequenas dimensões, iriam influenciar as emigrações de europeus para o novo continente. E consequentemente, esta foi uma das razões para que surgissem grupos como New York Schola Cantorum (1912), o coro feminino Dessoff Choirs (1924), Cantata Singer (1934) e o New York Chorus (1943), todos, evidentemente, especialistas na música vocal do passado, principalmente, renascentista. Posteriormente, a música instrumental incorporará essas preocupações, sobretudo com a entrada de professores com este perfil nas universidades, a criação de sociedades voltadas para a promoção da música antiga, a criação de cadeiras voltadas para a performance da música antiga, inclusive medieval. Tudo isso, com certeza, incrementou não somente a formação de grupos, como as atividades de concerto (AUGUSTIN, 1999: 2327).

No Brasil, os primeiros ecos dessa tendência chegariam somente a partir do final da década de 1940. No início, as atividades voltadas para o resgate da música antiga partiram de atitudes pessoais e, sobretudo de imigrantes europeus radicados no Brasil pós II Guerra Mundial. Porém, não tardaram atitudes institucionalizadas a fim de sistematizar e melhor acomodar músicos e atividades. Foi nesse sentido que, já em 1957, surgiu o Conjunto de Música Antiga da Radio MEC (AUGUSTIN, 1999: 44).

A chegada de Hans-Joachim Koellreutter, a partir de 1937 e sua preocupação não só com a música contemporânea, mas também com a música dos séculos XVII e XVIII, representou uma dinamização para a formação de repertório dos recitais nesta área. Além disso, como estava preocupado também com educação, Koellreutter conseguiu criar, a partir dos anos 50, a Escola Livre de Música, uma espécie de extensão do Curso Internacional de Férias Pró-Arte, voltados para o que consideravam a música não convencional na época (AUGUSTIN, 1999: 42).

A partir das experiências do conjunto da Radio MEC, dos Seminários de 
Música Pró-Arte, como ficou conhecido o Curso Internacional de Férias PróArte, a inclusão da música antiga no cenário brasileiro, vai influenciar toda uma geração posterior que assume para si a tarefa do desenvolvimento da performance histórica. E com o passar dos anos, quase todas as regiões do país vão criar seus grupos e atuar, muitas vezes, em instituições, seja em nível técnico ou superior, e buscar com isso uma continuidade das atividades nessa área e, eventualmente, profissionalização.

Evidentemente que a viagem de algum "líder" importante a fim de buscar especialização poderia alterar o panorama momentaneamente: tal como a troca de um professor numa instituição, a mudança de um componente de algum grupo ou mesmo novas configurações em conjuntos específicos. Porém, o que nos interessa, é que desde a década de 1950 sempre houve interesse na música antiga européia, incrementado, inclusive, com estudos específicos, dentro e fora do país a fim de buscar especializações. O que nos chama a atenção, de imediato, foi que esse interesse na performance da música antiga européia por parte de músicos brasileiros, ou radicados no Brasil, não despertou um interesse imediato desses músicos para a música anterior à nossa independência, ou seja, não despertou o interesse para a performance da música colonial brasileira.

Se no continente europeu a música pós-barroca, melhor dizendo, a música galante e clássica, foi paulatinamente incorporada ao pensamento da performance histórica (KERMANN, 1987:). no Brasil, o interesse pela música composta no século XVIII e primeiro quartel do século $X I X$, será completamente descartada pelos expoentes dessa linha de pensamento num primeiro momento. Antes, há uma tentativa de aproximação da música medieval e renascentista da música de tradição oral, sobretudo, a nordestina (AUGUSTIN, 1999: 84). Somente a partir de alguns anos, músicos e grupos que comungam desse pensamento, tem demonstrado interesse em incorporar em seu repertório a música colonial. Ou seja, um movimento que nasce na primeira década do século XX na Europa e que ganha força, sobretudo, após a segunda Guerra Mundial, que chega a estas terras antes da década de 1950 e somente começa a se interessar por obras compostas antes de 1822 no final da década de 1980 .

Quais seriam as razões para esse descompasso? Não seria natural que 
músicos preocupados com música antiga, ou melhor, atentos a obras musicais compostas em tempos passados e dentro de outros modelos de composição, interpretação e recepção, despertassem a curiosidade investigativa em resgatar modelos interpretativos diversos ou anteriores a parâmetros românticos? Ao contrário! Pelo que pudemos perceber, não houve um interesse pela música anterior ao romantismo composta nessas terras. Por outro lado, também não podemos afirmar que as descobertas musicológicas no campo da música colonial eram desconhecidas antes da década de 1960.

As pesquisas musicológicas no Brasil têm seu início, como sabemos, já no século XIX, com Araujo Porto Alegre (VOLPE, 2010), e seguem seu curso no século $\mathrm{XX}$, com publicações importantíssimas, tais como: $A$ música no Brasil, de Guilherme de Melo de 1908, História da Música no Brasil de Renato Almeida e Storia della musica nel Brasile de Vincenzo Cernicchiaro, ambos de 1926, Música e músicos do Brasil, de 1950 e 150 anos de música no Brasil, de 1956, ambos de Luiz Heitor. Portanto, ao iniciar suas atividades na década de 1940 em Minas Gerais, Francisco Curt Lange, não foi um pioneiro, mas contribui certamente, para a historiografia da música brasileira. Foi nessas terras e nessa época que o pesquisador teuto-uruguaio descobriu as primeiras partituras de Manuel Dias de Oliveira, José Emerico Lobo de Mesquita, entre outros. A partir dessas descobertas, alguns pesquisadores tomam para si a tarefa da pesquisa em outras cidades e regiões, sobretudo a partir da década seguinte. Poderíamos também afirmar que até o inicio da década de 1970 muito já se tinha feito e conhecíamos, pelos menos, as principais cidades e compositores onde houve produção musical razoável.

Alguns pesquisadores foram atrás de patrocinadores a fim de efetuarem não só publicações, mas também gravações contendo as obras trabalhadas: é de 1965 a gravação do Recitativo e Ária para José Mascarenhas (1756), efetuada pela Orquestra de Câmara de São Paulo regida por Olivier Toni; e da década de 1970 a série de LPs intitulada Música Sacra Paulista, coordenada pelo musicólogo Régis Duprat. É entre a década 1960 e 1970 que a pesquisadora Cleofe Person de Mattos começa a publicar as partituras de José Mauricio Nunes Garcia, hoje, quase reconhecido internacionalmente. O que pretendemos afirmar com essa pequenina digressão, é que havia um conhecimento da produção musical efetuada anteriormente à Independência do 
Brasil e, se não houve interesse por parte daqueles preocupados em performance histórica, não foi por ausência de informação. Insisto, portanto, na mesma pergunta: porque então uma parte desses músicos não se interessou em incorporar esse repertório às suas performances?

Umas das principais razões do desinteresse, a nosso ver, é que houve por parte dos adeptos da performance da música antiga, uma busca de capacitação técnica e não um interesse pela pesquisa histórica que também conduzisse à performance. Ou seja, os músicos brasileiros se dirigiram aos centros europeus especializados em música antiga, como Holanda, por exemplo, a fim de adquirir capacitação técnica para a interpretação, sobretudo da música barroca e renascentista, mesma atitude que caracterizou as tentativas do grupo de Koellrreuter da Pro-Arte. Buscavam um modo não convencional de tocar esse repertório (AUGUSTIN, 1999, p. 56) fundamentado em outros "paradigmas interpretativos" que não fosse à tradição romântica. Portanto, seus anseios ainda eram tecnicistas, ou seja, se concentraram em adquirir a técnica "apropriada" para a execução da música renascentista e barroca. E de modo algum se dirigiram aos pólos europeus de investigação da música antiga a fim de se tornaram pesquisadores dessa área, em que pesem suas pesquisas se refletirem numa atividade prática, ou seja, a performance. Dizendo de outro modo, não se dirigiram a esses pólos a fim de refletir sobre a pesquisa e construção de modelos interpretativos e sua relação com a historia, portanto, com as possíveis mudanças e transformações paradigmáticas, seja ao longo do tempo, portanto diacrônicas; sejam geográficas: sua adaptação aos países desse lado do Atlântico, e a partir de outras realidades históricas, se não totalmente diferentes, pelo menos diversas.

Dessa forma, na impossibilidade de uma aplicabilidade técnica ipsis puncti, do modelo de interpretação da música antiga (sobretudo barroca, por esta possibilitar todo um repertório instrumental variado) e terem que buscar outras soluções técnico-estilísticas, ou seja, outros modelos de performance, os adeptos da música antiga desprezaram nosso patrimônio histórico-musical. Nesse aspecto, desenvolveram certo preconceito em relação à música produzida no Brasil durante o século XVIII, sobretudo por esta não ser estritamente barroca, mas estar dentro de um estilo que poderia ser classificado de galante e posteriormente clássica (DUPRAT, 1985). 
A ausência de um mercado interno, também dificultou, e muito, o investimento em produção de registros sonoros e publicações, e este fato não se liga apenas à assim chamada performance histórica, mas à música de concerto como um todo: se o mercado para música erudita no Brasil é exíguo e não desperta interesses de grandes investidores da indústria fonográfica; a subdivisão desse mercado em uma fatia ainda menor afastaria ainda mais os possíveis investidores, sejam estes nacionais ou internacionais. Note-se que deste lado do Atlântico, diferentemente do mercado europeu e estadunidense, a música erudita como um todo, não teve grande adesão nem do mercado editorial, nem da indústria fonográfica, e isso, certamente, dificultou a divulgação da música erudita no Brasil; e muito.

Somente a partir da década de noventa e, sobretudo após a virada do terceiro milênio, vamos experimentar uma profusão de registros contendo música colonial e de modinhas e lundus efetuados pelos adeptos da música antiga $^{40}$. De qualquer modo, isso foi impulsionado, num primeiro momento, pelas comemorações dos 500 anos de descobrimento do Brasil e posteriormente pelas comemorações da chegada da Família Real em 2008. A entrada de instrumentistas especialistas em música antiga nos conservatórios, sobretudo municipais ${ }^{41}$ e posteriormente nas cadeiras das universidades ${ }^{42}$, num primeiro momento, também não representou uma grande mudança de atitude em relação ao interesse pela música brasileira dos séculos XVIII e início do XIX. Somente após a estruturação dos cursos de pós-graduação em musicologia dos departamentos de música das diversas universidades públicas e, consequentemente, a criação de linhas de pesquisa especializadas na música brasileira, vem ocorrendo, muito paulatinamente, mudanças neste

\footnotetext{
40 Cf.: Música de salão do tempo de D. Maria I - Segréis de Lisboa - Manuel Morais - Lisboa, PT: Moviplay, 1994; Modinhas e Lunduns dos séculos XVIII e XIX - Segréis de Lisboa - Manuel Morais Lisboa, PT: Moviplay, 1997; 20 Modinhas - J. Manoel da Câmara / Sigismund Neukomm - Luiza Sawaia Pedro Persone - SP/Br., 1998; Brasil 500 anos - Quadro Cervantes - RJ: 2000; Sempre Amor: Portuguese love songs from the romantic Age - Lorna Anderson, Soprano and Apollo chamber players. London: Independent Records, 2002; Modinhas de Amor - Lira d'Orfeo - Edilson de Lima. Séc. da Cultura- Guarulhos - SP: 2004; Amor Brasileiro - Modinhas e lundus do Brasil - 2004 Emsemble vocal e instrumental \& Vox Brasiliensis - Ricardo Kanji - SP / K617- França, 2004; Modinhas - Capella Brasílica - Rodrigo Teodoro. MG, 2005; Lundu de Marruá - Lira d'Orfeo - Edilson de Lima. $\quad$ Paulus - SP: Paulus, 2008; Modinhas cariocas - A música na corte de d. João VI: Candido Ignácio da Silva, Gabriel F. da Trindade, J. Manoel da Câmara - Marcelo Fagerlande - RJ: Biscoito Fino, 2007/8; O sacro e o profano. Quarteto Colonial - Maria Ainda Barroso. Rio de Janeiro: Biscoito Fino, 2006/7.

${ }^{41} \mathrm{Na}$ década e 1980, já havia curso de flauta doce no Conservatório Municipal de São Paulo e Conservatório Municipal de Guarulhos ministrado por Bernardo Piza, especialista em falta doce e traverso borocas no conservatório de Amsterdã. Holanda.

${ }^{42} \mathrm{Na}$ década de 1990, Helena Jank cria o Curso de Cravo da UNICAMP.
} 
panorama. Mas, de qualquer forma, ao considerarmos o registro efetuado por Lenita Bruno no cd Modinhas fora de moda efetuado em 1958, a modinha e lundu, sobretudo pelo que tem representado para a historiografia da música brasileira (e falo isso sem arroubos nacionalistas) e pelo que tem proporcionado aos pesquisadores e interpretes, tem feito parte do repertório registrado em gravações há pelo menos meio século! 


\section{O classicismo europeu}

\subsection{Formação e afirmação}

O estilo clássico, tão sintomaticamente associado a Haydn, Mozart e Beethoven, seguramente grandes expoentes como afirma Charles Rosen (1986), tem seus antecedentes não só na busca de maior simetria na elaboração do discurso musical, esteja esta associada à macro (forma sonata, concerto, entre outras) ou a micro-forma (frases articuladas e periódicas, semifrases); mas também em discussões sobre a questão do afeto em música, ou seja, na utilização de temas contrastantes em uma mesma seção. Problemas relacionados com a linguagem musical focados nas discussões do estilo contrapontístico versus melodia acompanhada também concorrem, e não de modo menos importante, para a afirmação desse estilo durante o século XVIII.

A tonalidade foi seguramente um dos aspectos mais importantes para "lo advenimiento del estilo clásico (ROSEN, 1986, p. 28) ${ }^{43}$. Ou seja, toda a experiência relacionada à modulação, sobretudo a polarização entre dominante e tônica, desenvolvida no século XVII, não será descartada; mesmo as sequências melódico-harmônica, uma das grandes conquistas do estilo barroco, farão parte do discurso harmônico clássico, sobretudo nas seções de desenvolvimento. Porém, se a harmonia seqüencial é a força motriz que impulsiona e suporta o estilo barroco; no estilo clássico, a frase articulada, assumirá esta posição (Idem, 1986, p. 57). E nesse sentido, a elaboração da frase articulada traz, pelo menos, duas consequênicas de suma importância para o novo estilo: uma "la exaltación de la sensibilidade por la simetria" e "una estructura rítmica muy variada donde los distintos ritmos no se contrastan ni superponen, sino que fluyen y se intercambian com sumafacilidad e lógica." (Idem: 1986, p. 69) ${ }^{44}$. E será em função da melodia que serão elaboradas técnicas como: o baixo de Alberti, ou acordes arpejados de todos os tipos, "figurations" (clichês de acompanhamento); além da potencialização de uma escrita homófono-harmônica, em detrimento da escrita contrapontística.

\footnotetext{
43 "o advento do estilo clássico" (T.A.)

44 "a exaltação da sensibilidade pela simetría"; "uma estrutura rítmica muito variada onde os ritmos distintos não se contrastam nem se superpões, mas que fluem e se intercambiam com suma facilidade e lógica" (T.A.).
} 
Evidentemente que o que conhecemos hoje por estilo clássico não foi elaborado de um modo coeso e num espaço curto de tempo. Mas os anos precisaram passar para que uma grande quantidade de procedimentos estilísticos pudessem ser absorvidos e se fixassem como hegemônicos ao gosto dos compositores e interpretes e, mais tarde, compusessem um conjunto de procedimentos que acabaram por definir não só um estilo, mas um período histórico. Atualmente, algumas técnicas, tais como, o baixo de Alberti, já comentado acima, contrastes dinâmicos e expressivos, a melodia articulada e periódica, entre outros, parecem estar bem introjetados na musicalidade vigente.

Hoje, dotados de um vasto repertório pertencente aos séculos XVII e XVIII, bastante organizado e divulgado, podemos desenvolver uma consciência sobre o quanto da escrita idiomática barroca persistiu no estilo clássico e o que de clássico já existia no estilo barroco. Por exemplo: a questão da frase simétrica pode ser encontrada em vários compositores ainda pertencentes ao Período Barroco e segundo Charles Rosen, "la música de Stamitz, el viejo, combina el fraseo clásico primitivo con la secuencia armónica del barroco" (ROSEN, 1986, p. 27) ${ }^{45}$. E, obviamente, esta tendência para a frase simétrica, tem sua origem nas danças do século XVI e será perpetuada na suíte barroca do século XVII (Idem, 1986, p. 54). Porém, somente a partir do século XVIII ela será potencializada como uma marca registrada do estilo que virá, o clássico, e passará a ser encarada como uma força motriz de uma tendência hegemônica.

Já a harmonia seqüencial, uma das marcas incontestes do estilo barroco, será completamente absorvida nas seções de desenvolvimento das sonatas e óperas e usada, como antes, em expansões melódicas, tal e qual nos séculos precedentes (DUPRAT, 1985, p. 65). Desta forma, podemos concluir que as experiências do século XVII no campo da harmonia e do contraponto tonal, foram de importância fundamental para o estilo que viria e, de modo algum, podem ser considerados fatores secundários, mas continuam vigentes por muito tempo ainda na música religiosa até o final do século XVIII, o último bastião do estilo clássico (ROSEN, 1986; DUPRAT, 1985).

\footnotetext{
45 "a música de Stamitz, o velho, combina o fraseado clássico primitivo com a sequência harmônica do barroco" (T.A.).
} 
A polarização entre tônica e dominante, uma característica marcante da música clássica, foi largamente experimentada e usada nas suítes, sonatas, por exemplo, antes de ser condensada em um procedimento estrutural: "El movimiento hacia la dominante formava parte de la gramática musical, pero no era um elemento formal" (ROSEN, 1986, p. 40) ${ }^{46}$. Porém, no século XVIII, a própria estrutura da frase articulada com sua divisão tradicional em duas semifrases: a primeira antecedente, finalizando suspensivamente na dominante; e a segunda conseqüente, finalizando na tônica. Neste caso, o movimento para a dominante deixa de ser uma meta, um direcionamento, para tornar-se um procedimento estrutural.

Outro fator a ser considerado, e que será de importância fundamental para o século XVIII e já mencionado acima, é a persistência de uma escrita em estilo barroco na música sacra: a preferência pela caracterização 'afetiva' nos seguimentos da missa ainda persistiu na música sacra que somente assumirá um estilo clássico também no discurso musical após a virada do século XIX (ROSEN, 1986; DUPRAT, 1985). Porém, a busca de simetria, que pode ser sintetizada na frase articulada e periódica, é sem sombra de dúvida uma das marcas registradas do estilo musical a partir da secunda metade do século XVIII:

"El fraseo articulado, periódico, trajo como consecuencia dos alteraciones fundamentales en la naturaleza de la música del siglo XVIII: una de ellas fue la exaltación de la sensibilidad por la simetría llevada a límites casi sofocantes; y la segunda, una estructura rítmica muy variada donde los distintos ritmos no se contrastan ni superponen, sino que fluyen y se intercambian con suma facilidad y lógica" (ROSEN, 1985, p. 69) ${ }^{47}$.

A busca de simetria e articulação, não se trata de uma simplificação da frase barroca, sempre em expansão motívica e suportada, evidentemente, por uma harmonia caminhante, sequencial; ao contrário, a polarização entre tônica e dominante, como suporte harmônico da frase, trata-se de uma opção onde o

\footnotetext{
46 "O movimento para a dominante formava parte da gramática musical, porém não era uma elemento formal" (T.A.).

47 "O fraseado articulado, periódico, traz com conseqüência duas alterações fundamentais na natureza da música do século XVIII: uma delas foi à exaltação da sensibilidade pela simetria levada a limites quase sufocantes; e a segunda, uma estrutura rítmica muito variada onde os distintos ritmos não se contrastam nem se superpõem, mas fluem e se intercambiam com suma facilidade e lógica" (T.A.).
} 
que importa destacar é a melodia, entendida como a mais alta expressão da sensibilidade musical; a melodia, a natureza tornada música, segundo Rousseau ${ }^{48}$.

Evidentemente que a tendência à simetria e ao formalismo não ocorreu apenas nas pequenas formas, ou seja, nas frases e períodos, nos minuetos e canções, ou nas formas derivadas de danças; mas foi uma tendência que também acometeu as chamadas grandes formas, como as sonatas e concertos. E quando sugerimos uma tendência para o formalismo, não estamos afirmando que os esquemas formais sejam estáticos e rígidos, pois a sonata como foi praticada em fins do século XVIII se diferencia seguramente daquela praticada na primeira metade de século XIX; e como sugere Rosen (1994, p. 14), "Suponen que la forma tiene una história: en otras palabras, que está sujeta a cambios” ${ }^{49}$. Como afirma a seguir o mesmo autor, o próprio termo "forma sonata" foi calcado por A.B. Marx no início do século XIX com base nas obras de Ludwig van Beethoven com uma intenção puramente pedagógica, ou seja, normativa (Idem, 1994, pp. 15-16). Mas, independentemente de um maior ou menor caráter estático da sonata, há no século XVIII uma tendência em pensar uma obra formalmente, em construí-la em partes distintas, sobretudo, insistimos, após o alto formalismo já experimentado nas pequenas formas e, principalmente, na frase musical, esta a nosso ver, a pedra de toque desta tendência.

Importa também ressaltar que toda a música instrumental do século XVIII, em especial a assim chamada forma sonata, alcançou um alto grau de dramaticidade: os temas funcionavam como verdadeiros personagens, com personalidade e caráter; a passagem de um para outro grupo temático demandava, seguramente, pequenas ou longas passagens modulatórias, ou transições, onde se estabeleciam verdadeiros conflitos psicológicos... Em suma, o formalismo clássico do século XVIII não prescindiu de um sentido de

\footnotetext{
${ }^{48}$ Nesse aspecto, a fala de Rousseau de que a natureza inspira melodia e não contraponto sintetiza as expectativas não só do filósofo, mas da época; para um aprofundamento dessa discussão, ver: VIEIRA DE CARVALHO, M. Razão e sensibilidade na comunicação Musical. Lisboa: Antropos, 1999; também, FUBNI, E. L'estetica musicale dal settecento a oggi. Torino: Piccola Biblioteca Einaudi, 1987 e Estetica della musica. Bologna: II Mulino, 1995; e DAHLAHUS, C. Estética Musical. Lisboa: Edições 70, 2003.

49 “Supõem-se que a forma tem uma história: em outras palavras, que está sujeita a mudanças". (T.A.).
} 
transformação, pois sua causalidade interna (modulação à dominante na exposição; modulações para os tons mais inusitados e contrastantes no desenvolvimento; o lavor com os vários temas e suas eventuais transformações; o uso elaborado da gama dinâmica e articulações...), se comporta como um verdadeiro conflito dramático, e no mais estrito senso teatral! (ROSEN, 1986, p. 81).

Nesse sentido, a ópera cômica, diferentemente da ópera séria, onde cada personagem assume um papel carregado de conteúdo emocional específico e, portanto, constante, tem papel fundamental para a elaboração do estilo clássico. E não somente isso, também

"As árias das óperas cômicas são tipicamente num estilo galante, efetuadas a partir de frases curtas e melodiosas, frequentemente repetidas ou variadas, organizadas dentro de períodos e acompanhadas por harmonias simples e figuration." (BURKHOLDER, 2006, p. 486)

E nesse sentido os concertos públicos que irão surgir no final do século XVII e se desenvolver a partir do século XVIII, serão fundamentais para a popularização do que se veio a convencionar como estilo galante: suspiros finais do estilo barroco para uns; e primeiros ares do estilo clássico para outros. A nosso ver, as investidas estilísticas nesse gênero representaram 0 nascimento de um novo estilo, que vai conduzir, e não sem titubeios, ao estilo clássico vienense, que tem como representantes máximos Haydn, Mozart e Beethoven (ROSEN, 1986).

Mas retornando ao que dizíamos anteriormente, a valorização da ópera buffa na Itália, do vaudeville na França, da zarzuela na Espanha, trazem para o mundo do espetáculo, cada qual à sua maneira, tendências populares, não só no que diz respeito à temática satírica presente em todos esses gêneros, mas sobretudo à valorização de melodias populares e da frase articulada. E nesse sentido, tanto a melodia quanto as gêneros musicais "bufos", serão uma das bases principais de afirmação e divulgação do estilo, além de alimentarem as querelles do século XVIII, auge da discussão sobre o modelo musical barroco (ainda calcado na expansão motívica aliada à harmonia sequencial e ao contraponto) versus o que se convencionará chamar de clássico, preocupado, primeiramente com uma melodia organizada em frases periódicas e articuladas 
com base em uma harmonia disposta em ritmos homófonos e na polarização entre a tônica e dominante.

Desta forma, a popularização do estilo clássico, não está vinculada, de forma alguma, a uma suposta "simplificação" harmônico-melódica, como sugerem alguns, tomando como parâmetro a minimização do contraponto e do baixo não mais cantante; mas também a fatores estéticos, ou seja, a uma nova concepção a respeito da música e sua relação com a natureza e nossos sentidos; e sociológicos: a entrada em cena da burguesia como elemento fundamental para a nova ordem política e econômica, e sua relação com a produção cultural.

\subsection{O natural e o simples como modelo}

É evidente que esta mudança estética vinha ocorrendo desde o final do século XVII. Como acenado acima, o surgimento dos concertos públicos e todo um aparato como teatros, organização de espetáculos e futuras edições para a burguesia e classe média pagante, e a inclusão dessa camada social dentro de uma estrutura de produção e recepção, marcarão uma mudança radical: a arte passará a ser reflexo não só dos anseios da igreja e da monarquia (éticopedagógica), mas também refletirá o pensamento da burguesia, e a entrada dessa camada social no centro das decisões não pode ser desconsiderada. $E$ nesse sentido, além dos modelos metafísicos religiosos e cosmogônicos do pensamento da igreja e da monarquia, uma racionalidade calcada em outra concepção da natureza e, principalmente, sua relação com o sentimento e a sensibilidade, vai fundamentar o pensamento musical a partir do alvorecer do século XVIII.

Para o pensamento do século XVIII, a natureza será o lugar do equilíbrio e o modelo a ser seguido pela arte. Como tão bem sintetizou Mário Vieira de Carvalho, a concepção de natureza será base para outras categorias de suma importância para a arte: natureza e simplicidade; natureza e verdade, natureza e coração, natureza e virtude, natureza e acessibilidade (VIEIRA DE CARVALHO, 1999, pp. 73-119). O ideal de imitação da natureza, como sabemos, remonta à antiguidade clássica, e será um dos temas constantes no 
mundo da arte; e irá, mais uma vez, fundamentar toda uma mudança estética entre o final do século XVII e início do XVIII.

Nesse sentido, todas as demais categorias (simplicidade, verdade, coração/sentimento, virtude e acessibilidade) buscaram na "natureza", o modelo a ser seguido. $E$ é nesse contexto, que 0 sentimento ou sentimentalismo, associado à concepção de sensação, deve ser compreendido: "A natureza (...) antes de tudo sente-se" (BOILEAU, apud VIEIRA DE CARVALHO, 1999, p. 89). Portanto, deixar-se comover, ou melhor, permitir ser tocado pela arte, em nosso caso pelos sons; essa experiência subjetiva e intransferível é uma das finalidades da música. E é por isso que se pode afirmar:

"Basta senti-lo, não é necessário nomeá-lo. O coração tem a sua inteligência independente das palavras, e, quando ele é tocado, compreendeu tudo" (BATTEUX, apud, VIEIRA DE CARVALHO, p. 94).

\subsection{Música religiosa e estilo clássico}

Outra questão de não menor importância está relacionada, como acenado acima, à música religiosa vigente em todo o século XVIII: se a ópera bufa da primeira metade do século XVIII já contém os germes do estilo clássico (conflito emocional e contraste musical; frases musicais simétricas e periódicas; ênfase na melodia acompanhada); e se podemos afirmar que o estilo clássico se estabiliza na música instrumental a partir de 1770, sobretudo nas sinfonias e concertos de Josef Haydn (Cf. GROUT, 2006; ROSEN, 1985); na música religiosa, as tendências classicizantes irão se cristalizar de modo ainda mais lento e, evidentemente, mais tardiamente.

A missa, sobretudo aquela com função litúrgica, tem partes bastante definidas no que tange à caracterização do afeto, ou estado emocional específico: urge a um Kyrie eleison que tenha caráter introspectivo; já um Gloria, merece ser tratado com grande júbilo e exuberância; o Alleluia, por sua vez, tem que possuir caráter alegre e festivo... Desta forma, toda a teoria pertencente ao estilo barroco é absolutamente pertinente para caracterização emocional de cada segmento de uma missa (DUPRAT, 1985). Nesse sentido, a feitura de uma missa que pudesse sustentar em cada segmento, em um Kyrie, 
por exemplo, que apesar de possuir duas partes distintas, Kyrie eleison e Christe eleison, têm que funcionar como afirmação de um estado emocional constante: o sentimento de piedade do Pai e de seu filho para com a humanidade. Portanto, um contraste musical em estilo clássico, poderia destruir todo um conteúdo emocional e sua função redentora dentro da liturgia. Desse modo, a escrita em expansão motívica do estilo barroco e a caracterização de um único afeto por segmento, continuam como a técnica fundamental a ser usada; e a que vai ser respaldada pela ideologia da igreja vigente.

Foi, portanto, por esse motivo que o último bastião a ser tocado pelo estilo clássico, vem a ser a missa e, por conseqüência, toda a música de caráter religioso; pois, uma aplicação dos parâmetros já completamente absorvidos pela música de concerto ou a ópera (melodia articulada, polarização em T-D, contrastes temáticos e dinâmicos, a escrita homofônica e o baixo de Alberti) deveriam ser completamente repensados para uma aplicação que não soasse superficial em uma peça religiosa.

Não é por outra razão, que na música de igreja, persiste até inicio do século XIX, procedimentos musicais muito caros ao estilo barroco. Segundo Duprat, uma espécie de prima e seconda práticas do final do século XVIII (Idem, 1985). E esta tendência não será uma exclusividade da música religiosa praticada nas colônias da América Portuguesa, mas, como bem afirma Charles Rosen, uma prática da música européia, e, também, da música religiosa efetuada em Viena no final do século XVIII, a capital do estilo clássico! (ROSEN, 1986: 421)

\subsection{A Popularização da música no século XVIII}

\subsubsection{Música para não profissionais}

Com o advento do século XVIII, a ascensão da burguesia e o aumento da classe média, a demanda por formação musical cresceu consideravelmente, de modo que muitos músicos profissionais se beneficiaram ministrando aulas para instrumentistas e cantores não profissionais (GROUT, 2006, p. 475). E à medida que "la musica se iba conviertiendo en una elegância social" (ROSEN, 
1986 , p. 54$)^{50}$, aumentava a demanda para aulas particulares. De modo que cabe a pergunta:

"?Cabe la posibilidad de que el carácter amateur de la mayor parte de la música para teclado de la segunda mitad del siglo XVIII se deba al hecho de que el pianoforte estaba reservado casi exclusivamente a las mujeres?" (Idem, 1986, p. 54) ${ }^{51}$.

Evidentemente que a produção de peças, tanto instrumentais quanto vocais, direcionadas para esse "publico alvo" deveria ter incremento considerável. E muitas das sonatas para piano dessa época foram compostas para tal demanda; e mesmo sonatas para violino e piano, ou trios e quartetos com piano e que apresentam menos dificuldades técnicas, estavam direcionadas para a educação das senhoritas e senhoras (Idem, 1986, pp. 5455). Não queremos dizer com nossa afirmação que não houvesse sonatas com um alto grau de dificuldade técnica; e nem que não houvesse mulheres profissionais nessa época; sobretudo cantoras; mas enfatizar o quanto a produção musical se beneficiou com esta realidade.

Outra consequência dessa virada cultural foi o surgimento de um mercado de partituras para teclado, música de câmara, ou para voz e teclado. E um pouco mais tarde, com o aumento de coneusseurs em matéria de música, além dos profissionais da área, não tardaram as revistas e periódicos, com curiosidades e críticas (GROUT, 2006, p. 475). Tampouco queremos ignorar a manifestação musical advinda de uma origem oral, e praticada pelos camponeses; porém não é este nosso foco. O que nos interessa é justamente como um modelo estilístico musical vai se democratizando através não só dos concertos públicos, do ensino particular e da publicação de partituras e periódicos, ou seja, através do que irá denominar-se mais tarde de uma cultura urbana.

\footnotetext{
50 "a música ia se convertendo em uma elegância social” (T.A.).

51 "Cabe a possibilidade de que o caráter amador da maior parte da música para teclado da segunda metade do século XVIII era pelo fato de que o pianoforte estava reservado quase exclusivamente para as mulheres" (T.A.).
} 


\subsubsection{Concertos públicos e intermezzi}

É evidente que os concertos públicos, que têm sua origem já no final do século XVII na Inglaterra, foram um dos grandes impulsos para a popularização da música durante o século XVIII (GROUT, 2006: 476). À medida que a burguesia vai se tornando a mola propulsora do sistema econômico e, consequentemente, se desenvolvendo uma classe média ${ }^{52}$ e o operariado urbano, a demanda por entretenimento também aumenta. Assim sendo, a voga dos concertos públicos que vai se espalhando pela Europa será uma das molas principais para a popularização e, sobretudo, para a mudança de estilo que vai se operando na música.

Também os intermezzi, "um outro importante tipo de ópera cômica italiana", representados entre os atos das óperas sérias (Idem, 2006, p. 487), vai ganhando espaço nos teatros da época. Justamente por serem peças de pequeno porte, com dois ou no máximo três personagens e um pequeno grupo de instrumentos, permite que sejam encenadas também em pequenos teatros. Além disso, pelo seu teor cômico, os intermezzi absorvem a linguagem da opera buffa que será de importância vital para a mudança do estilo praticado na música do inicio do século XVIII. Nesse sentido, La serva padrona, de Giovanni Battista Pergolesi (1710-1736), será fundamental, pois não só os contrastes emocionais presentes nas personagens além dos contrastes instrumentais, a opção por uma escrita homofônica e menos contrapontística, a busca de frases periódicas e articuladas, apresentando mais de um motivo ou afeto, uma das bases fundamentais do estilo clássico, será esboçada nesta obra, antecipando tendências que irão se estabilizar ao longo do século no assim chamado estilo clássico vienense (Ibidem, 2006, p. 488).

Não foi sem motivo que esta obra de Pergolesi, La seva padrona, protagonizou o cisma entre defensores da ópera séria (antibuffonistti) e defensores da ópera bufa (buffonistti), após sua segunda apresentação em 1752 em Paris. A famosa querelles apontava, na verdade, para um rompimento com o modelo musical ainda ligado à concepção ético-pedagógico religiosa ou

\footnotetext{
52 Usamos aqui o termo classe na acepção de Immanuel Wallerstein: "Claro que sei que classe não é uma categorização que considere apenas a rena, mas, seja qual for a definição de classe, a maioria dos analistas concorda que há uma correlação direta entre classe e o nível de renda total, seja como conseqüência ou como causa." (WALLERSTEIN, 2006, P. 100)
} 
cosmogônica que vigoraram no século XVII. E o foco "nel libero fluire della melodia" (FUBINI, 1995, p. 94), que devia fundar-se "sulla libera invenzione e sulla fantasia" (Idem, p. 94) ${ }^{53}$, era um passo não só em direção à estética do sentimento, mas também, à emancipação das sensações; um passo para a emancipação da vida sensível (EAGLETON, 1993, p. 18). Também nesse sentido, a "revolução" de Christoph Willibald Gluck (1714-1787), ao buscar na "simplicidade", ou ao resolver "remover os abusos que deformaram a ópera italiana" (GROUT, 2006: 498), e na "naturalidade" da fala o fluir da melodia, é um passo em direção oposta às concepções barrocas.

Além das óperas, dos intermezzi e da musica religiosa, uma produção de canções visando a um público não profissional e para uso doméstico, ou seja, para os salões privados, foi sendo produzida nos vários países do continente europeu. A maioria dessas canções era deveria ser simples, silábica, diatônica e estrófica, com acompanhamento e que pudesse ser realizado pelo próprio cantor ou cantora (Cf. p. 33). É este tipo de canção que na Alemanha será consagrado como lied, na França como romance, na Inglaterra como ballad, na Itália como arietta e na Espanha como seguidilla. E no mundo luso-brasileiro, foi denominada modinha, ou seja, canção amorosa, singela, estrófica, formalmente construída por frases ao gosto clássico (articulada e periódica) para uma ou duas vozes e acompanhamento simples efetuado para teclado ou guitarra (Cf.: CRUZ, 2000; MORAIS, 2000; LIMA, 2001).

Portanto, todo esse aparato da criação dos concertos públicos, da produção de partitura para a classe média emergente e as classes mais populares, mais do que uma lógica de mercado, representou não só a difusão de um modo de vida baseado nos anseios da burguesia e calcado nos ideais iluministas, que valoriza o natural e simples como modelo estético a ser perseguido; mas também pretendia um novo projeto sócio-cultural e político. $\mathrm{E}$ se as classes populares não foram incluídas diretamente nesse projeto político, não puderam ser excluídas totalmente e adentraram à concepção estética: pois, mesmo que não possuíssem bens materiais a serem barganhados, ou

\footnotetext{
53 "no livre fluir da melodia"; "sobre a invenção e a sobre a fantasia" (T.A.).
} 
conhecimentos ideologicamente elaborados que servissem de modelos a serem seguidos; traziam consigo, pelo menos aqueles bucólicos camponeses, além de uma vida em simplicidade com suas canções e danças; também uma proximidade bastante grande com a "sábia" natureza: e isto não poderia ser descartado, aliás, será cada vez mais valorizado no século que se anuncia.

$\bullet$ 


\section{O estilo clássico nos trópicos}

\subsection{Formalismo, simetria e as modas da terra}

A modinha e o lundu, como discutimos acima, surgem como gêneros musicais a partir da segunda metade do século XVIII, se afirmando, mais especificamente, a partir do último quartel, portanto numa época na qual o estilo clássico é o modelo a ser seguido. É durante esse período que o substantivo modinha vai se afirmando e, apesar de não substituir as demais classificações como moda, cantiga, romance, vai se generalizando. Também é nessa época que o lundu, ainda bastante preso à sua forma dançada, vai se configurando como canção autônoma.

A moda das cantigas de salão é fruto de uma cultura burguesa ilustrada e da sua contrapartida, a classe média emergente; e mais tarde, os trabalhadores urbanos (NERY, 2005: 24) que vão se intensificando durante o século XVIII. Evidentemente a participação nos salões, a ida à ópera, tanto nos teatros das classes mais abastadas quanto nos teatros dos bairros menos favorecidos, exigia outros modos, mais afeitos à nova sociabilidade nascente. Nesse sentido, ser ilustrado, saber dançar e cantar fazia seguramente parte de uma nova educação, e exibir os dotes em salões privados, dançando, tocando ou cantando, fazia parte da vida social desse novo porvenir (NERI, idem: 30).

É dentro desse contexto que a modinha tornar-se-á um modelo de sociabilidade, sobretudo para as moças dessa época (MACHADO NETO, 2008:). O licencioso lundu, por sua vez, já praticado pelas camadas populares na colônia brasileira, também adentra as casas dos burgueses e a corte, ainda que sofrendo acomodações na sua coreografia. No que tange à sua vertente cantada, como veremos no texto que segue, também se adaptará ao universalismo cultural/musical da época que também invade Portugal (NERY \& CASTRO, 1999); mas deixará marcas profundas até os dias de hoje.

Ir à ópera, assistir aos entremezes com números de modinhas e lundus exibidos nos teatros da Rua dos Condes ou do Bairro Alto, também serviu seguramente para a popularização desses gêneros. Nesse sentido, a incorporação do estilo italiano na melodia dessas singelas canções, foi um aprendizado "natural". Além disso, as publicações que irão surgir também 
nesse último quartel do século XVIII, como o Jornal de Modinhas ${ }^{54}$, fecharão o círculo para a consagração da modinha e do lundu como gêneros que farão parte da história da cultura luso-brasileira em fins do século XVIII e inicio do XIX.

\subsubsection{O formalismo clássico e a modinha}

Como afirmamos acima, a modinha e o lundu são frutos de uma cultura universalista que dominou o século XVIII, ancorada no pensamento ilustrado, e que pretendia, grosso modo, irmanar o homem não só pela razão, mas também pelo sentimento e com base, evidentemente no modo como esses dois âmbitos da natureza humana eram entendidos pelo ocidente (JIMENEZ, 1999: 80). Na música, além do reconhecimento de seu potencial sentimental, a questão formal, sua contrapartida racionalizada, será um dos pontos-chave para o desenvolvimento desse estilo. $\mathrm{E}$ neste aspecto, tanto a modinha quanto $\mathrm{o}$ lundu-canção, se encaixam perfeitamente dentro desses pressupostos.

A modinha, com dito acima, nasce como uma "canção estrófica, com ou sem refrão, de temática essencialmente amorosa e sentimental" (BARVOSA, 2003, p. 31) disposta em uma grande variedade formal. Além das formas binárias e ternárias, há modinhas, verdadeiramente pequeninas, que são compostas por uma única seção subdividida em frases. O lundu, como discutiremos abaixo, se comportará tal e qual a modinha: também abusará da forma poética estrófica, possuindo as formas musicais binárias e ternárias tão comuns nas canções de salão no século XVIII e início do XIX. Porém, além dessas opções formais, o lundu instrumental desenvolverá também a forma tema e variação. É evidente que por formalismo não entendemos apenas a macro-forma ou quantidade de seções que uma determinada peça comporta; mas também suas opções fraseológicas e articulações rítmico-melódicas. E será justamente este aspecto, a opção pelo tipo de fraseado e sua articulação interna, que diferenciará uma frase barroca de uma clássica, a despeito de ambas estarem dispostas em um mesmo número de compassos.

\footnotetext{
54 Jornal de Modinhas, periódico publicado quinzenalmente durante cinco anos (1792-96) a fim de divulgar a canções da época com a participação de vários compositores. Para mais informações, ver ALBUQUERQUE, M. J. D. 1996 e também o site da Biblioteca Nacional de Lisboa: www.bn.pt.
} 
As formas acima destacadas têm sua origem muito antes do que se convencionou classificar de Período Clássico: tanto a forma binária como o tema e variação que, inclusive, serão muito exploradas durante o século XVII. Já as formas ligadas às danças, uma das bases do formalismo clássico e as formas improvisadas, têm início ainda mais remoto e já se encontram em plena vigência no século XVI. Porém, a conjuntura estética do século XVIII vai conferir a essas formas a sua própria interpretação, sobretudo no que diz respeito à simetria, à periodicidade e à articulação interna das frases, pilares importantes do estilo clássico, sobretudo nas pequenas formas.

Ainda referindo-nos à questão formal, é necessário que se esclareça que ao tratar de cantigas ou árias, sobretudo àquelas efetuadas em ocasiões não formais, como os salões ou entremezes teatrais, não terão a dimensão das árias da capo compostas para as óperas ou cantatas. Ao contrário, possuirão pequenas, quando muito, médias dimensões. Mas isso de modo algum será um entrave para sua riqueza expressiva e formal: mesmo tendo algumas vezes apenas doze compassos, sua estrutura poderá ter as mais diversas combinações configurando-se em uma única seção, em formas binárias ou ternárias, como dito acima, com ou sem estribilho.

\subsubsection{Seção única}

As modinhas que possuem uma única seção são geralmente construídas sobre uma única estrofe. No caso da modinha Menina você vai hoje, do manuscrito Moinhas do Brasil (LIMA, 2001, p. 181), o poema utilizado possui apenas dois versos, ou seja, trata-se de um dístico e a música é composta, também, por duas frases de quatro compassos iniciadas em anacruse, seguindo o padrão simétrico clássico: as duas frases são compostas por duas semi-frases cada, sendo a primeira formada pela repetição exata do mesmo padrão rítmico melódico; e a segunda, repete apenas o padrão rítmico, mas varia a melodia. $O$ que seria interessante frisar, é que nesta pequenina modinha, além das "sincopes características" (ANDRADE, 1962[1928]) ${ }^{55}$ que Ihe conferem um ritmo menos marcado, acresce o fato de a primeira frase ter sido harmonizada na tonalidade de Fá, subdominante do tom principal: dó

\footnotetext{
${ }^{55}$ Conceito de Mário de Andrade para o grupo rítmico semicolcheia, colcheia e semicolcheia.
} 
maior; já a segunda, apesar de iniciar em dó maior, é finalizada suspensivamente, tendência bastante presente nas peças dessa coleção.

\section{Menina você vai hoje}

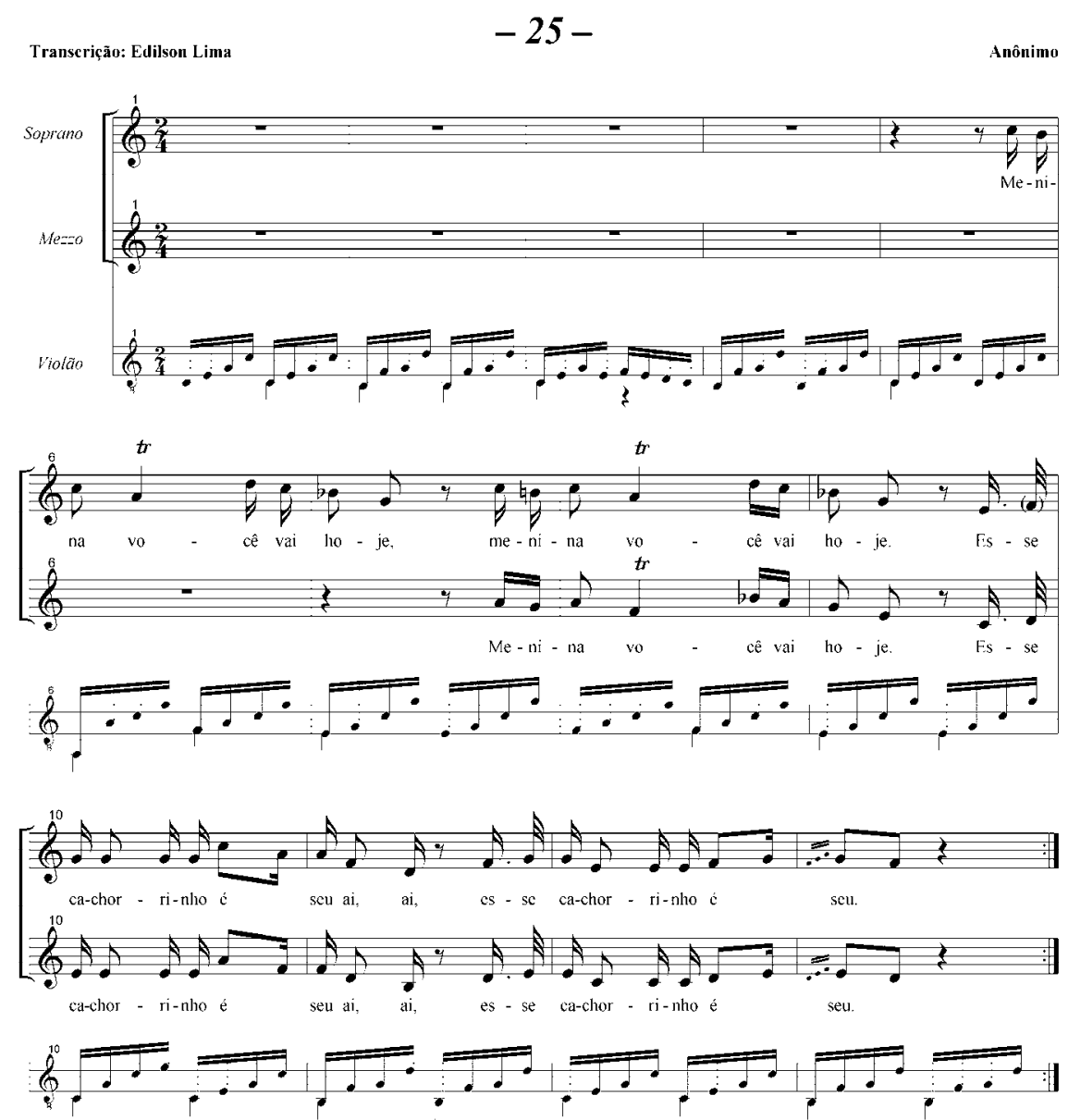

Menina você vai hoje, Modinhas do Brasil (LIMA, 2001)

Outra peça, também do mesmo códice, e que foi escrita em uma só seção, a modinha Tristemente a vida passa (LIMA, 2001, p. 77-78), é formada por quatro frases independentes que têm como suporte uma quadra: a primeira e a segunda frase musical foram construídas a partir do primeiro e do segundo verso: "Tristemente a vida passa / Quem ao longe vive amando"; a terceira frase musical será construída sobre os versos terceiro e quarto da quadrinha, "Cresce o dia aumenta a mágoa / Sempre seu mal vai dobrando"; a quarta e última frase, utiliza-se do último verso da estrofe precedido de uma interjeição "Ahai". 


\section{Tristemente a vida passa}

$$
-04-
$$
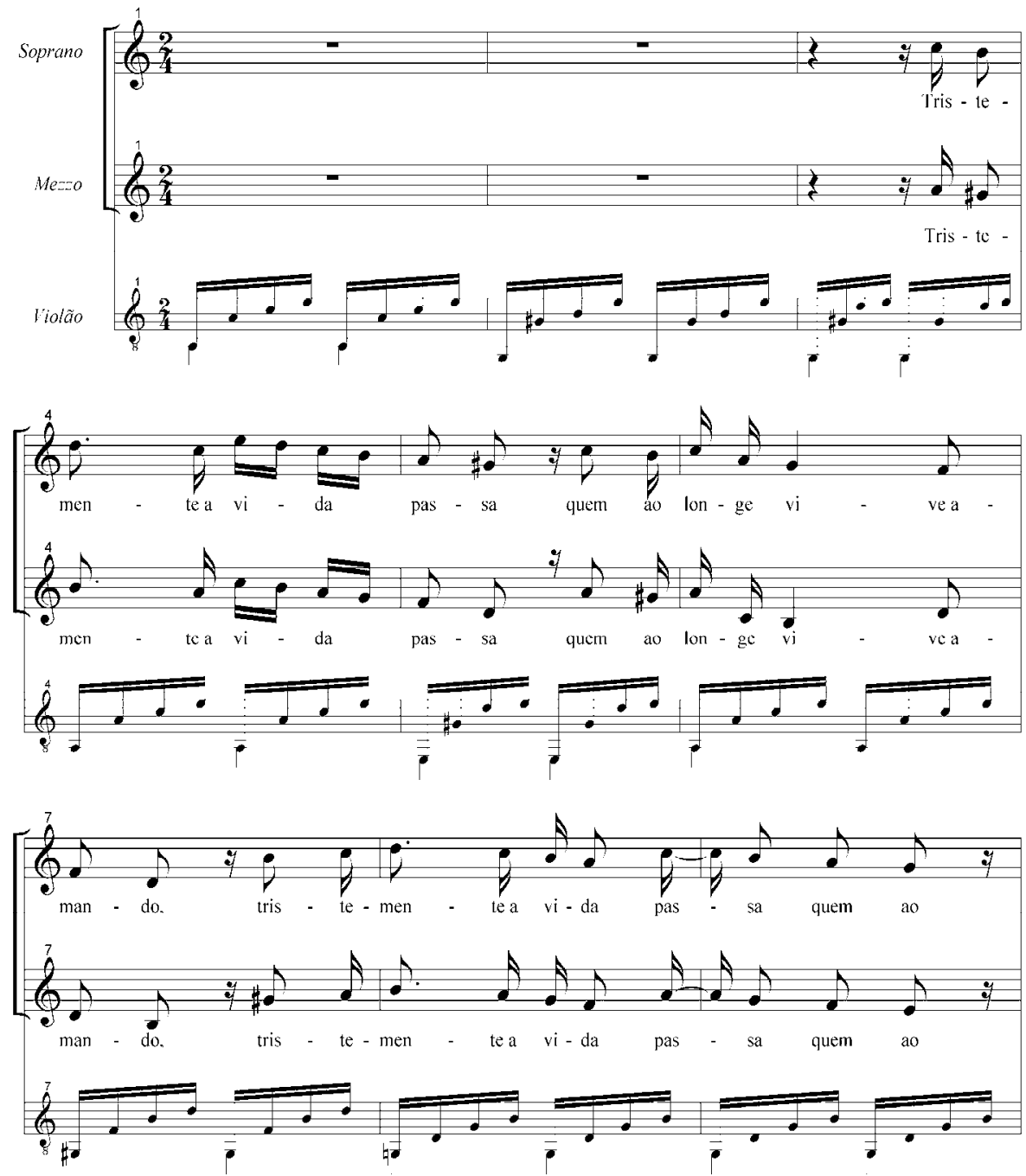

C) 1999 by Edilson de Lima 

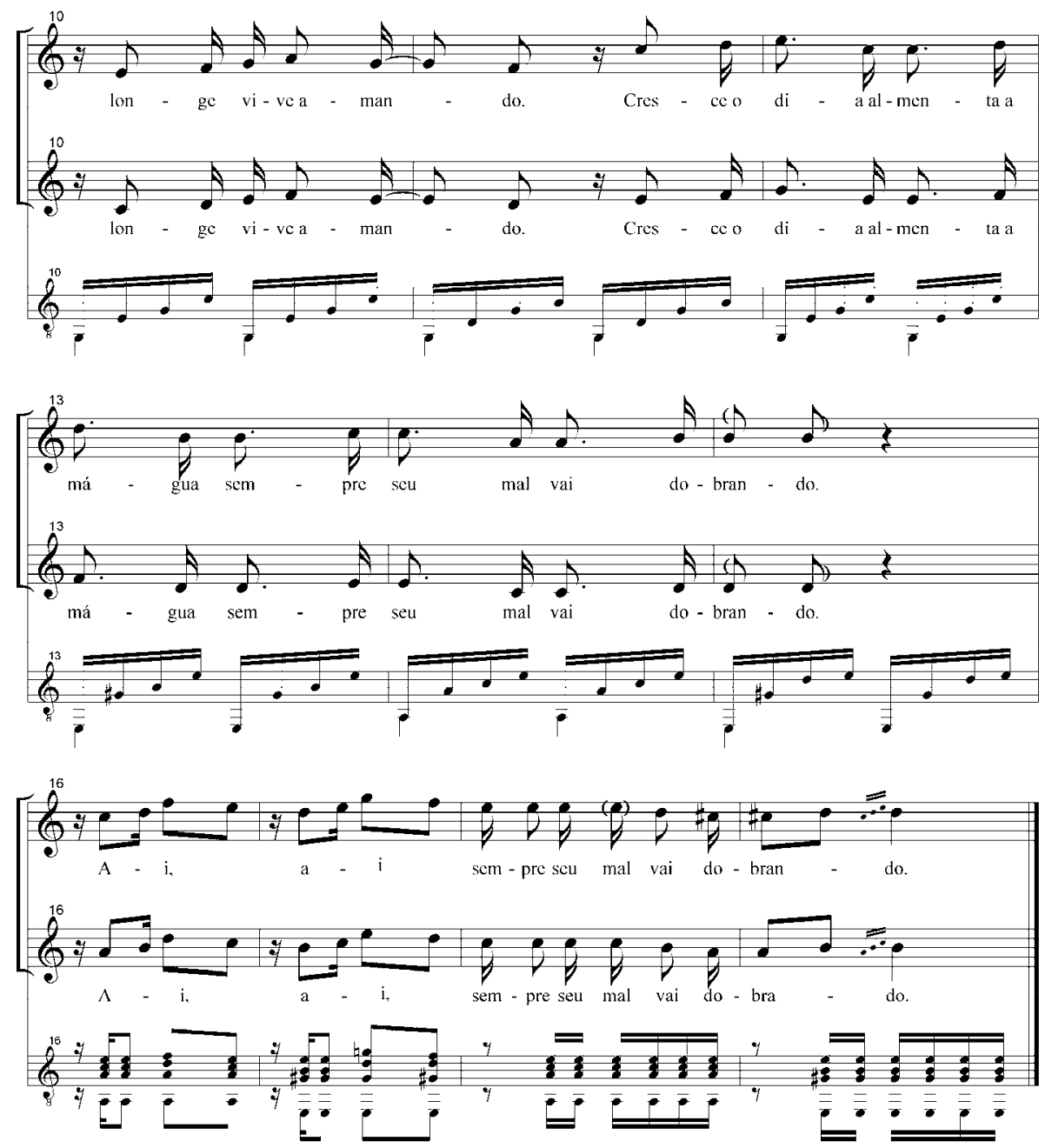

Tristemente a vida passa (LIMA, 2001)

Quase todas as frases desta modinha são iniciadas em anacruse, excetuando a quarta e, mesmo não se tratando de um lundu, a presença da síncope, questão que abordaremos no próximo texto, faz-se notar de modo bastante enfático. Porém, diferentemente da modinha precedente, na qual a síncope não ultrapassa as barras de compasso, nesta modinha, está disposta em frases de quatro compassos além do limite das barras, o que the confere um traço bastante peculiar, característica que será encontrada, como afirmado acima, em muitas peças desse códice e sobretudo nos lundus.

Outra modinha, Quando no campo vivia, pertencente ao códice Muzica escolhida da viola de Lereno (BARBOSA, 2003) foi analisada dentro desse mesmo esquema formal: 
"por fim, numa só canção ( . $^{\circ}$ 20), a música apenas apresenta uma secção na qual se canta a única estrofe copiada, sem repetir a música ou texto. Este processo composicional é conhecido sob a designação de durchkomponiert e foi usado, desde os finais do século XVIII, por compositores como Mozart e Haydn" (Ibidem, p. 35).

20. Quando no campo vivia

(Romance a duo)
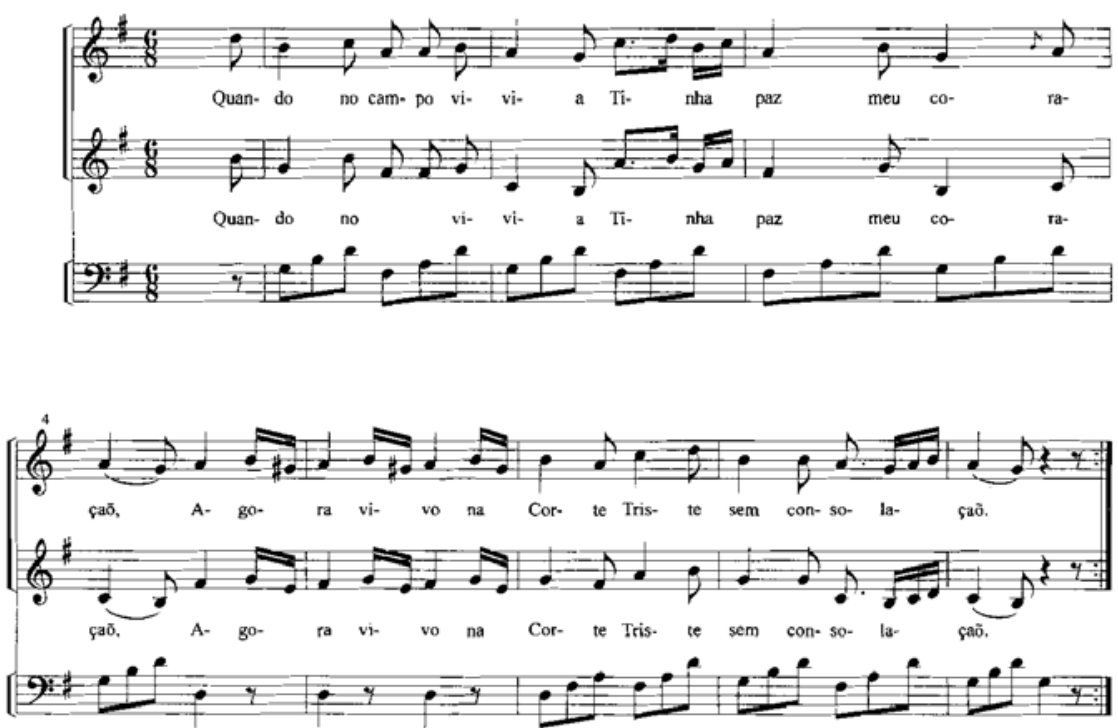

Quando no campo vivia (BARBOSA, 2003)

Esta afirmação, inclusive, vem ao encontro de nossa tese, que analisa tanto a modinha quanto o lundu como sendo manifestações que incorporam as tendências classicizantes elaboradas durante o século XVIII. Por sua vez, esta afirmação não contradiz, de modo algum, a incorporação de certas tendências populares já presentes não só nos poemas, como discutido no capítulo primeiro desta tese; também na música, que nasce da influência direta da ópera bufa, do vaudeville, e dos entremezes, os verdadeiros laboratórios do estilo clássico, e que vão se utilizar de formas advindas das danças e canções pastorais. Neste aspecto, o gosto pela singela modinha e pelo buliçoso lundu, se encaixa perfeitamente na valorização do sentimental e do singelo, verdadeiros pilares conceituais da cultura ilustrada do século XVIII (CARVALHO, 1993: 73-77). 


\subsubsection{Forma binária}

Outra forma muito comum tanto em modinhas quanto em lundus, seria aquela que divide a peça em duas seções distintas, ou seja, forma binária. A modinha Triste Lereno, que está dividida em duas partes, sendo a segunda (B) o estribilho. Porém, apesar desta divisão em duas seções distintas, com a presença dos ritorneli ao final da segunda frase da primeira seção (c. 8) e ao final da segunda seção (c.15), a seção $B$, também composta de duas frases, a primeira de três compassos e a segunda de quatro, disposta em sete compassos, repete exatamente a segunda frase da primeira seção (cc. 5-8) no final da segunda seção (cc. 12-15), caracterizando uma pequena forma ternária dentro da aparente forma binária, formada por frases periódicas e acompanhadas pelo não menos clássico baixo de Alberti. Neste caso, a modinha possuiria forma ternária e não binária como a classificou Morais (BARBOSA, 2003, p. 34):

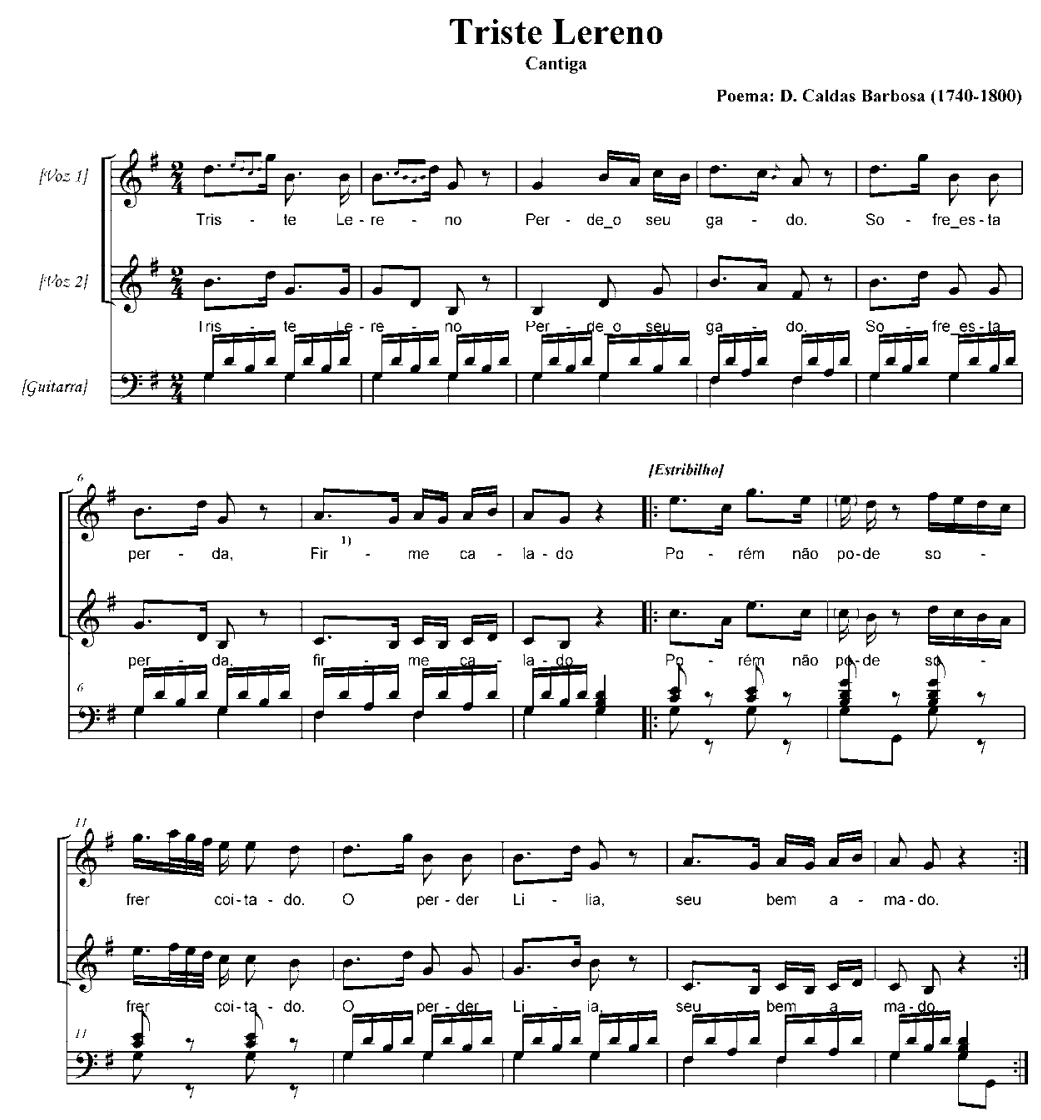

Triste Lereno (BABORA, 2003) 
Já a modinha baiana Foi-se Josino (SPIX \& MARTIUS, 1981[1820], p. 299) constitui um genuíno exemplo de forma binária: apesar da peça não possuir divisões claramente indicadas na partitura, podemos dizer que a seção A (cc. 1-8) é formada por uma frase de quatro compassos dividida em duas semi-frases, a primeira antecedente, finalizando suspensivamente (1-2) e a segunda semi-frase consequente, finalizando na tônica (3-4). Em seguida, a frase toda é repetida com uma pequena variação e finalizando esta seção, conduzindo a modinha para a segunda seção, um estribilho, formado por uma frase de cinco compassos, porém, completamente de acordo com os padrões clássicos, ou seja, formada por três motivos que se articulam e se sucedem de modo bastante orgânico.

\section{Foi-se Jozino}
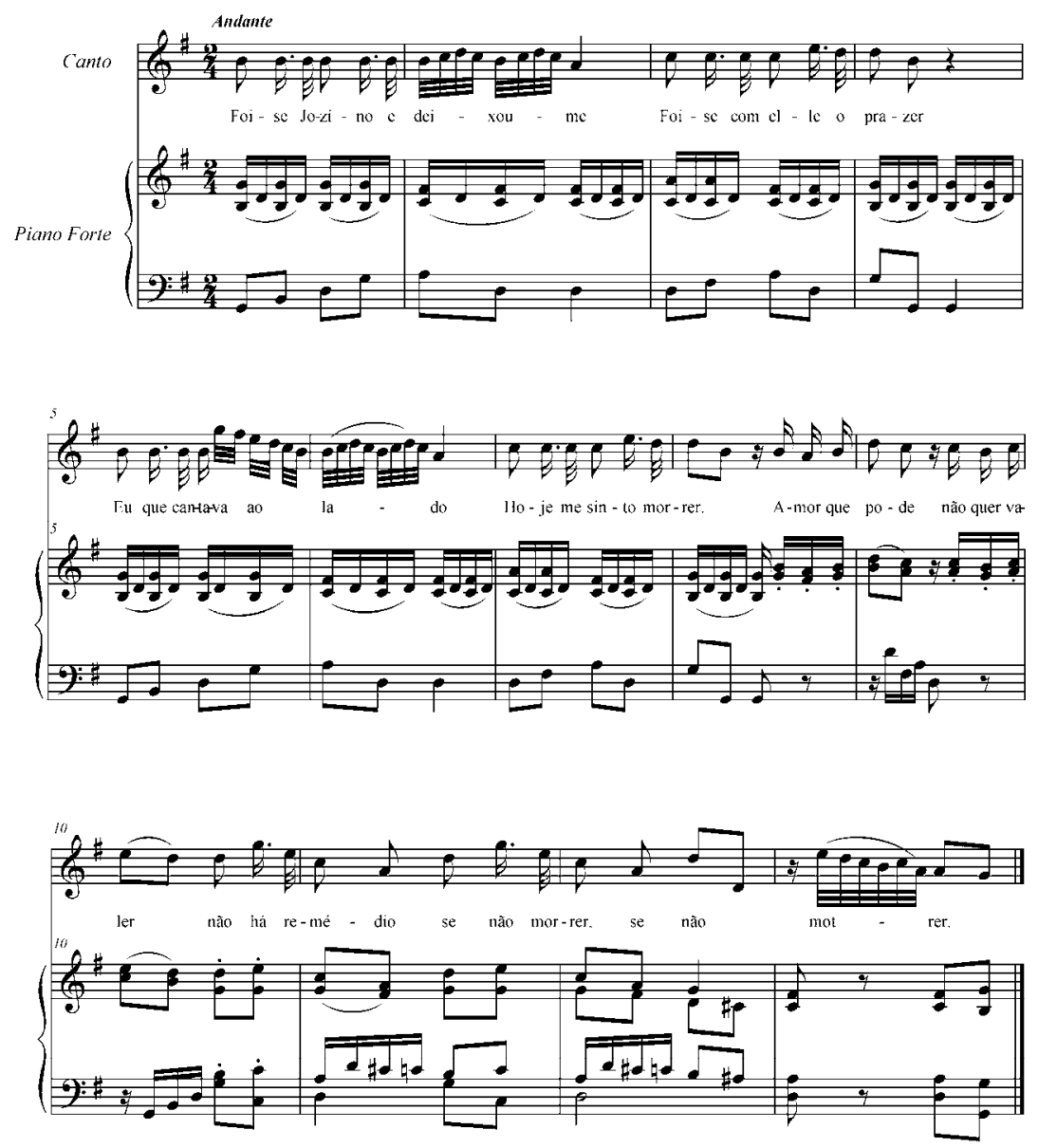

Foi-se Josino (SPIX \& MARTIUS, 1981[1820]: 299) 
Merece ser destacado que esta modinha, copiada pelos viajantes Johann Baptist von Spix e Carl Friedrich Phillipp von Martius na ocasião de sua viagem pelo Brasil entre 1817-1820 na região da Bahia, apesar do anonimato da música e do poema, possui o mesmo estribilho do poema de Domingos Caldas Barbosa, musicado duas vezes no códice Muzica escolhida da Viola de Lereno, com o nome Eu venho achar os pesares: a primeira como modinha; a segunda como lundu (BARBOSA, 2003). Exatamente o mesmo poema com o nome Não há remédio se não morrer, com o subtítulo Glosa de improviso, está no volume II do livro de poemas de Domingos Caldas Barbosa (BARBOSA, 1980, pp. 185-186). Descrevemos abaixo a primeira estrofe e o famoso estribilho do primeiro poema:

Eu venho achar os pesares, Onde os mais acham prazer; Amor que dá vida a todos, Só a mim me faz morrer

Amor, que pode Não quer valer, Não há remédio Senão morrer.

Portanto, a modinha Foi-se Jozino, bem pode ter sido gerada por um improviso poético musical efetuado por Caldas Barbosa, o Lereno, ou por algum músico presente em algum sarau setecentista; ou ter sido efetuada posteriormente, tendo como tema a glosa proposta pelo poeta que, seguramente, deve ter caído no gosto popular.

Outra modinha que nos chama a atenção exatamente por suscitar a mesma discussão, Quando a gente está com a gente, de autoria de Domingos Schiopetta, (1788-1835) ${ }^{56}$, possui o refrão que combina em parte com o refrão do poema Doçura de amor, também do segundo volume do Viola de Lereno de Domingos Caldas Barbosa (Ibidem, 1980, pp. 255-260):

[D. Schiopetta] Nós, lá no Brasil, Com a nossa ternura
[D. Caldas Borbosa]

Nós lá no Brasil

A nossa ternura

\footnotetext{
${ }^{56}$ Domingos Schiopetta, (1788-1835), tenor, compositor e arranjador de modinhas, violista, poeta, pintor arquiteto (MORAIS, 2000: 151) algumas de suas modinhas pode ser encontrada no site da Biblioteca Nacional de Lisboa (www.purl.pt/manuscrito)
} 
Açúcar nos sabe Com tanta doçura. Já fui á Bahia, Já passei o mar, Coisinhas que vi Me fazem babar.
A açúcar nos sabe, Tem muita doçura, Oh! Se tem! Tem.

Tem um mel mui saboroso

É bem bom é bem gostoso.

Acreditamos que o que foi escrito acima sobre a delicada modinha Foise Jozino, pode ser repetido ipsis literis para a delicadíssima modinha Quando a gente está com a gente, inclusive o fato desta peça também possuir forma binária: a seção $A$, com duas frases de quatros compassos sendo a segunda uma repetição variada da primeira; na seção $B$, que por sua vez trata-se do estribilho, contendo três frases de quatro compassos, sendo que a primeira e a segunda tratam-se da mesma frase repetida com texto diferente (cc. 9-16) e a terceira, construída sobre o verso "Coisinhas que vi me fazem babar", funcionando como uma espécie de codetta. Manuel Morais destaca, ainda, que

'Schiopetta usa os 'ingredientes' necessários para escrever esta modinha ao estilo 'brasileiro: melodia ondulante a 6/8 (compasso raramente usado na modinha portuguesa) com cromatismos que sublinham a adocicada letra, cheia de referências ao Brasil" (BARBOSA, 2003, p. 169).

\section{Quando a gente está com gente}

(Modinha)

Domingos Schiopetta
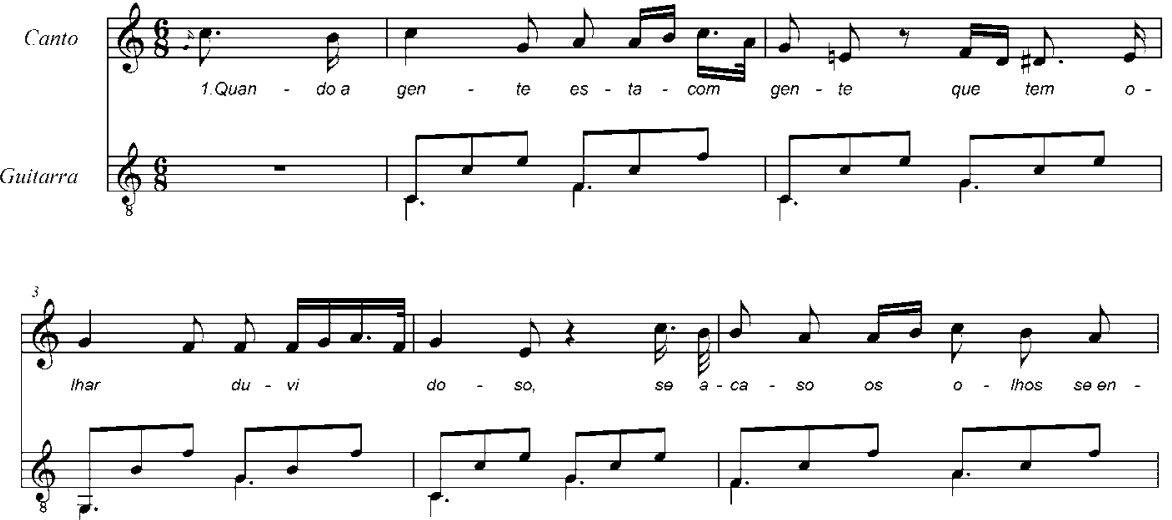

6

|Estribiho/ 

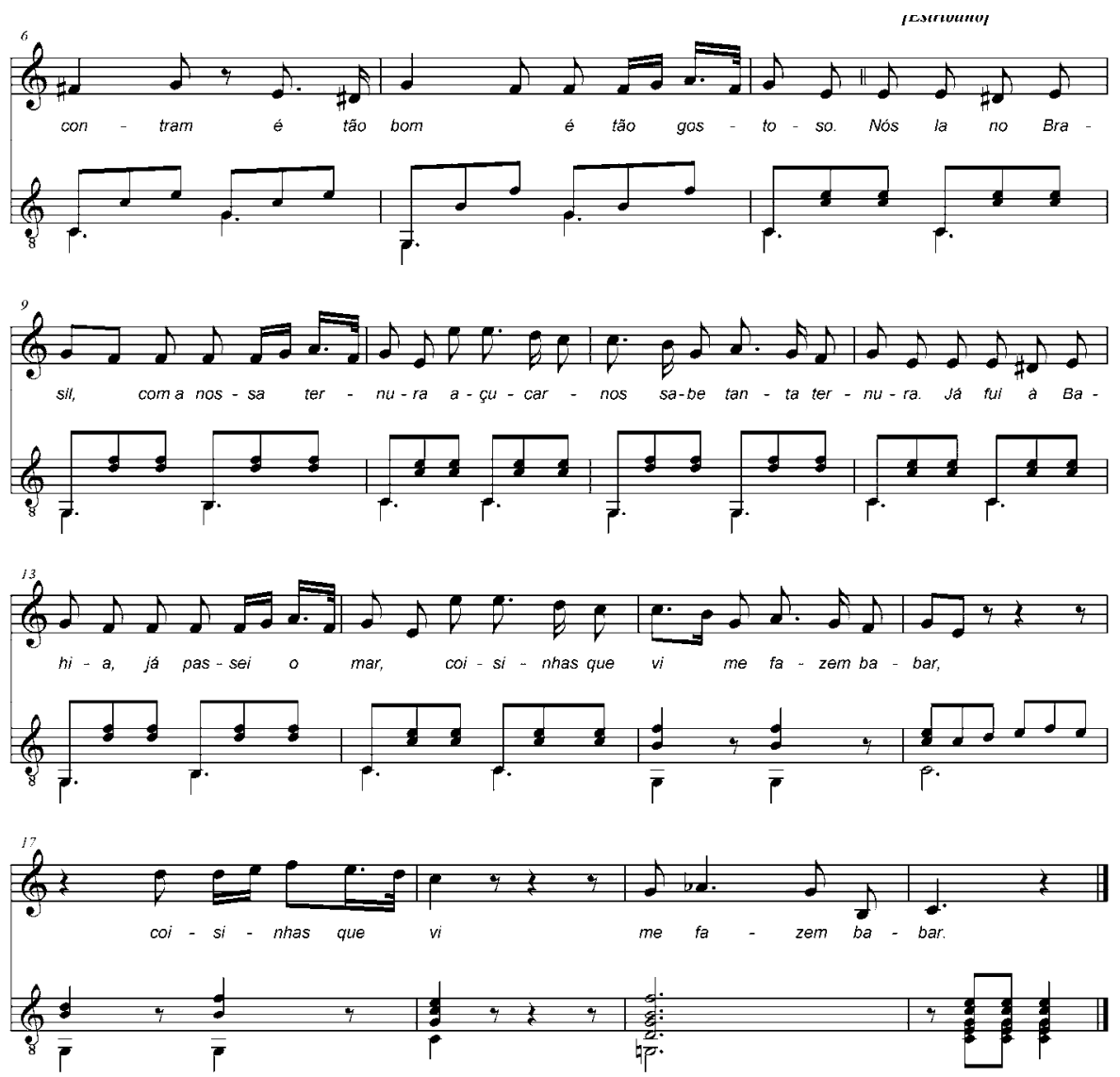

Quando a gente está com gente (MORAIS, 2000)

Outra modinha, Acaso são estes (Spix \& Martius, 1981[1821], vol. 1, pp. 256-257), também disposta em duas seções (A-B), é um exemplar bastante raro, não só por sua opção melódica que combina delicadeza e sofisticação; como pela combinação de frases de cinco e seis compassos na primeira seção (A) com frases de quatro compassos no estribilho (B).

A primeira seção inicia-se com duas frases repetidas formando um primeiro período (cc. 1-10) e efetuando cadência em sol maior, tonalidade principal. Em seguida, conduzindo a tonalidade para dó maior, subdominante, há uma frase de seis compassos, composta na verdade, por uma frase de quatro compassos com uma extensão de dois compassos. A frase seguinte, também de seis compassos, inicia-se numa interpolação, onde o final da frase precedente (ré-dó; c. 16), constitui início desta (cc. 16-21). Entre os compassos 22 a 25, uma frase de quatro compassos formada por elementos das frases precedentes, uma expansão melódica a guisa de coda encerrando a seção. 
O que deve ser frisado, é que todas as frases são formadas a partir de motivos melódicos extraídos das frases precedentes, articuladas internamente. Já a segunda seção, formada por três frases constituindo um período: a primeira com quatro compassos (cc. 26-29) a segunda, com seis, formada por uma frase de quatro compassos com uma extensão motívica de dois compassos; a terceira, uma variação da segunda, com quatro compassos. Portanto, ao utilizar-se da extensão motívica como recurso formal (STEIN, 1979, pp. 28-54; RATNER, 1980, p. 214), destaca que a aparente assimetria, trata-se na verdade de um elaborado formalismo e é seguramente por esta razão que esta modinha soa absolutamente simétrica aos nossos ouvidos
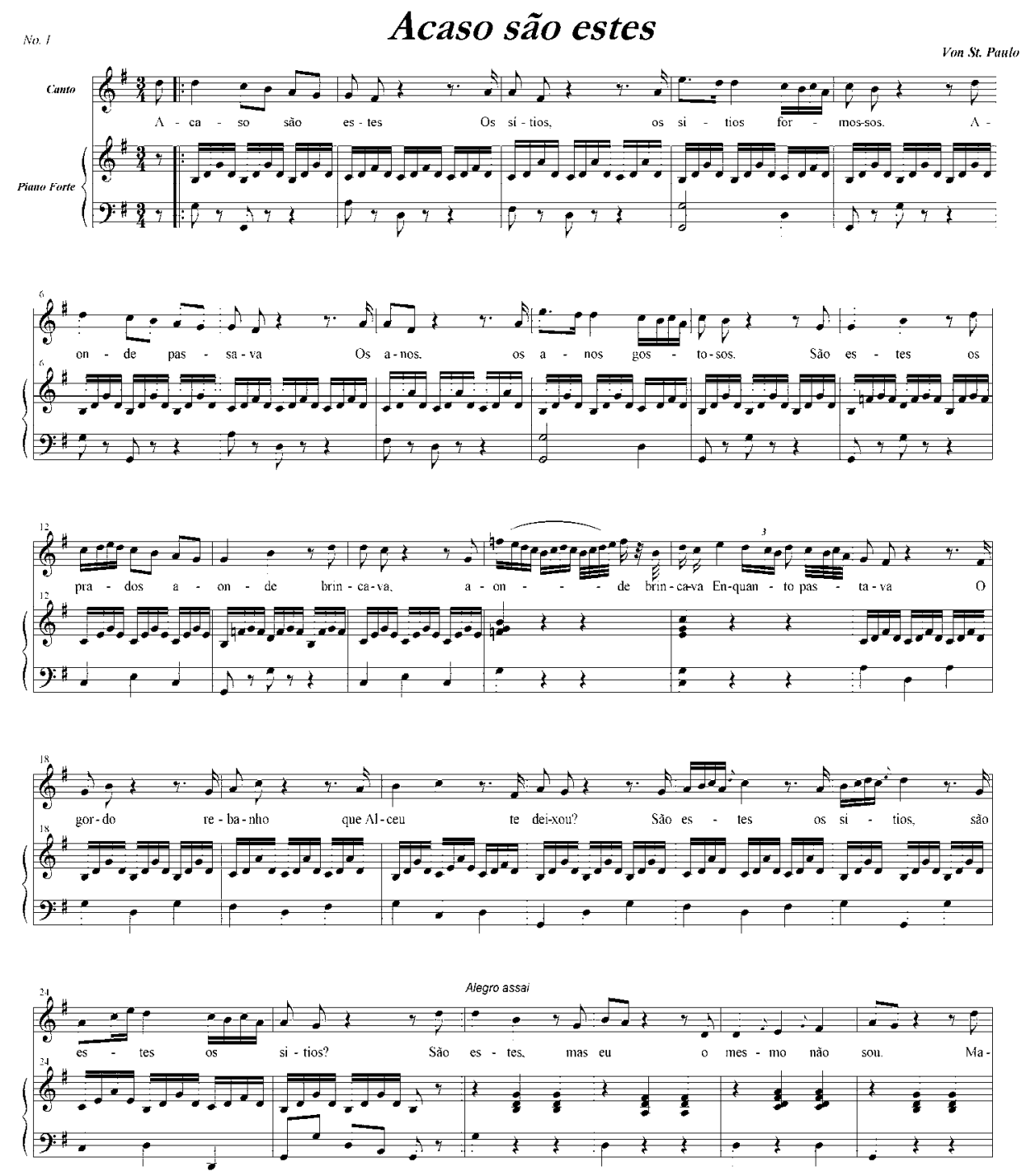


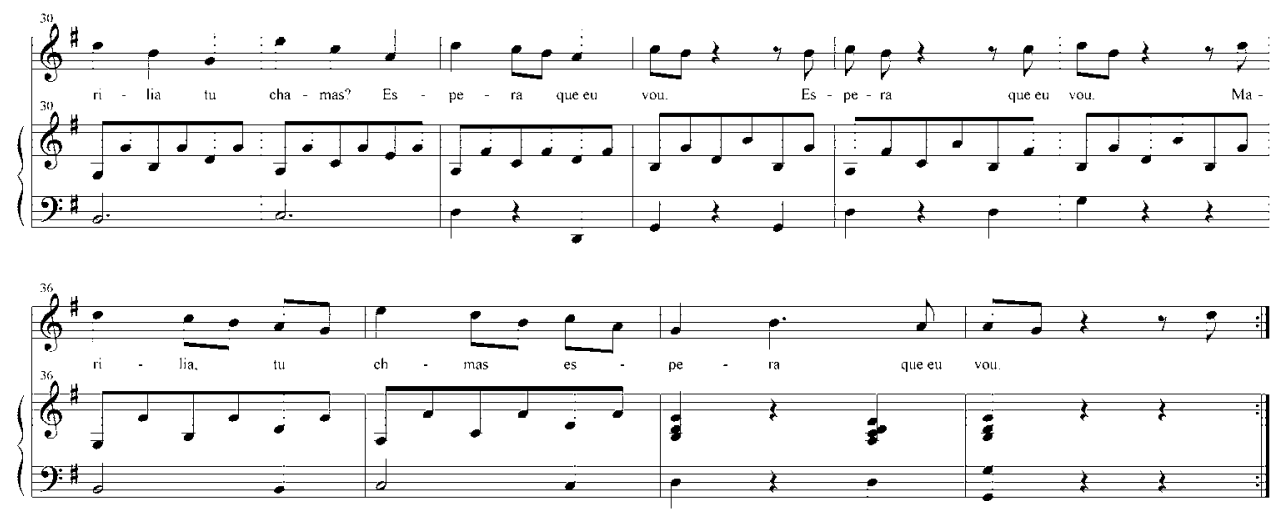

Acaso são estes (Spix \& Martius, 1981[1821])

\subsubsection{Forma Ternária}

A forma ternária, nas modinhas e também nos lundus, tanto pode se configurar como uma peça que possui três seções, sendo a última um estribilho ou uma coda, ou um ABA' como destacado na pequenina modinha Triste Lereno, que embora esteja dividida em duas seções, trata-se de uma forma ternária disposta na seguinte configuração: ||: A :||: B A' :\| (Cf. p. 138). Outro exemplo de forma ternária e que se comporta como a comentada anteriormente, é a modinha Perdi o rafeiro (SPIX \& MARTIUS, ob. cit. 259). Esta peça pode ser esquematizada exatamente como a anterior (\|: A :\|: BA' :||) onde a primeira seção foi construída com duas frases periódicas, porém variadas: a primeira contendo quatro compassos, sem a inclusão do anacruse (1-4), e a segunda, com cinco (cc. 5 - 9), sendo uma variação da primeira, expandindo a nota "sol" harmonizada como dominante com sétima e quinta no baixo na segunda metade do compasso sete, depois como dominante quarta e sexta na primeira metade do compasso oito, estendendo a frase em seu interior, e recuperando em seguida o fluxo para efetuar a cadência no compasso nove. Portanto, efetuando uma genuína expansão melódica dentro do estilo clássico, onde duas frases aparentemente assimétricas são, na verdade, construídas com base na simetria (STEIN, 1979, p.32).

A segunda seção (॥: B A" :||), também será composta por duas frases: a primeira de quatro compassos, completamente nova, efetuando cadência na dominante; a segunda frase, de cinco compassos, trata-se da uma frase A", na 
verdade, uma sutil modificação melódico-harmônico da variação da frase $A$. Importante frisar que todas as frases dessa modinha, assim como as demais analisadas nas modinhas acima, comportam-se como frases articuladas, ou seja, um estrutura rítmica e variada, onde os ritmos distintos e contrastante não superpõem, porém fluem se intercambiam com facilidade e coerência (ROSEN, 1985, p. 69); e periódica, já que busca na repetição, variada ou não, a lógica de uma pequena forma que deve ser facilmente escutada e reconhecida.

\section{Perdi 0 rafeiro}

No. III

Von S. Paulo
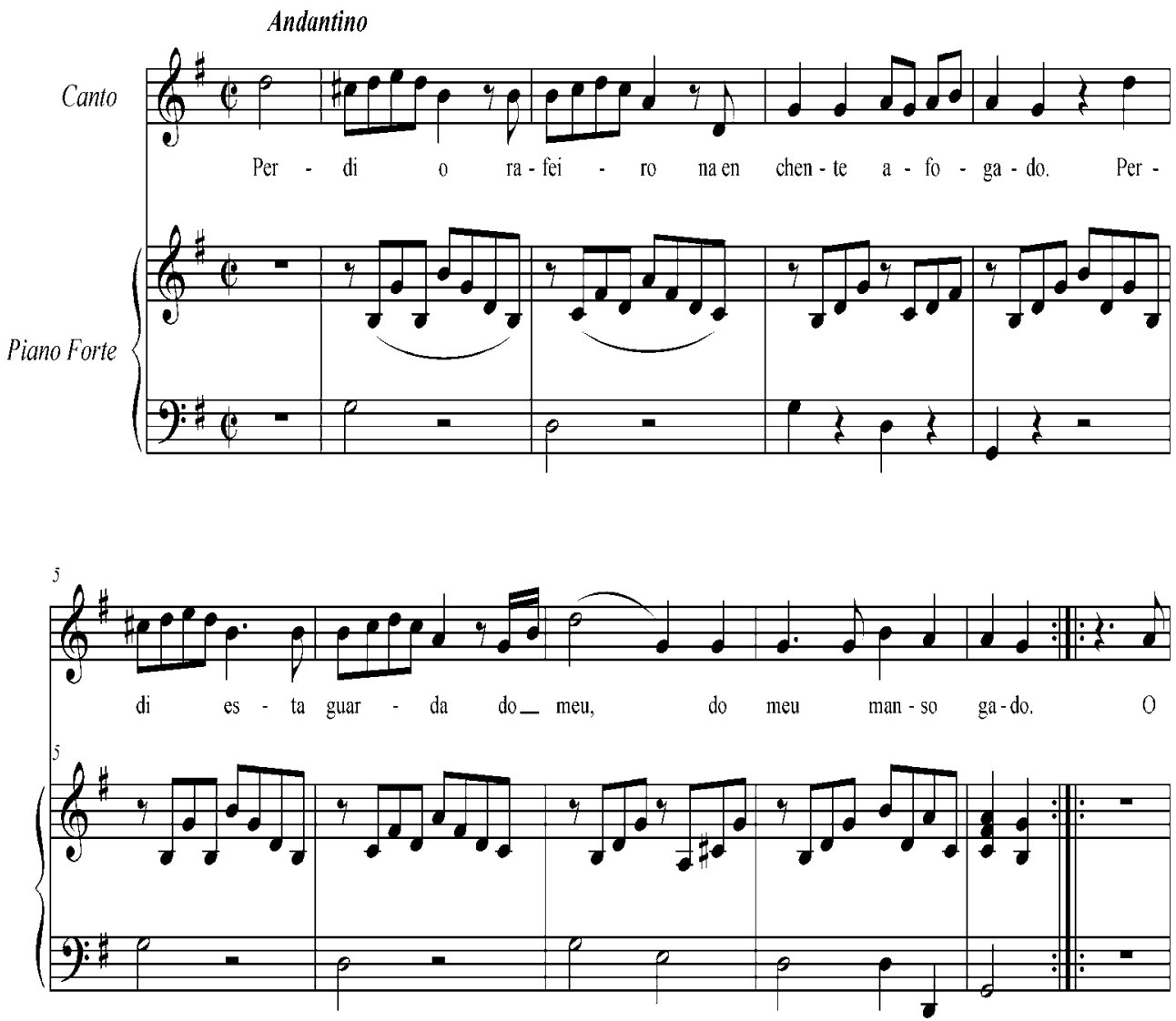

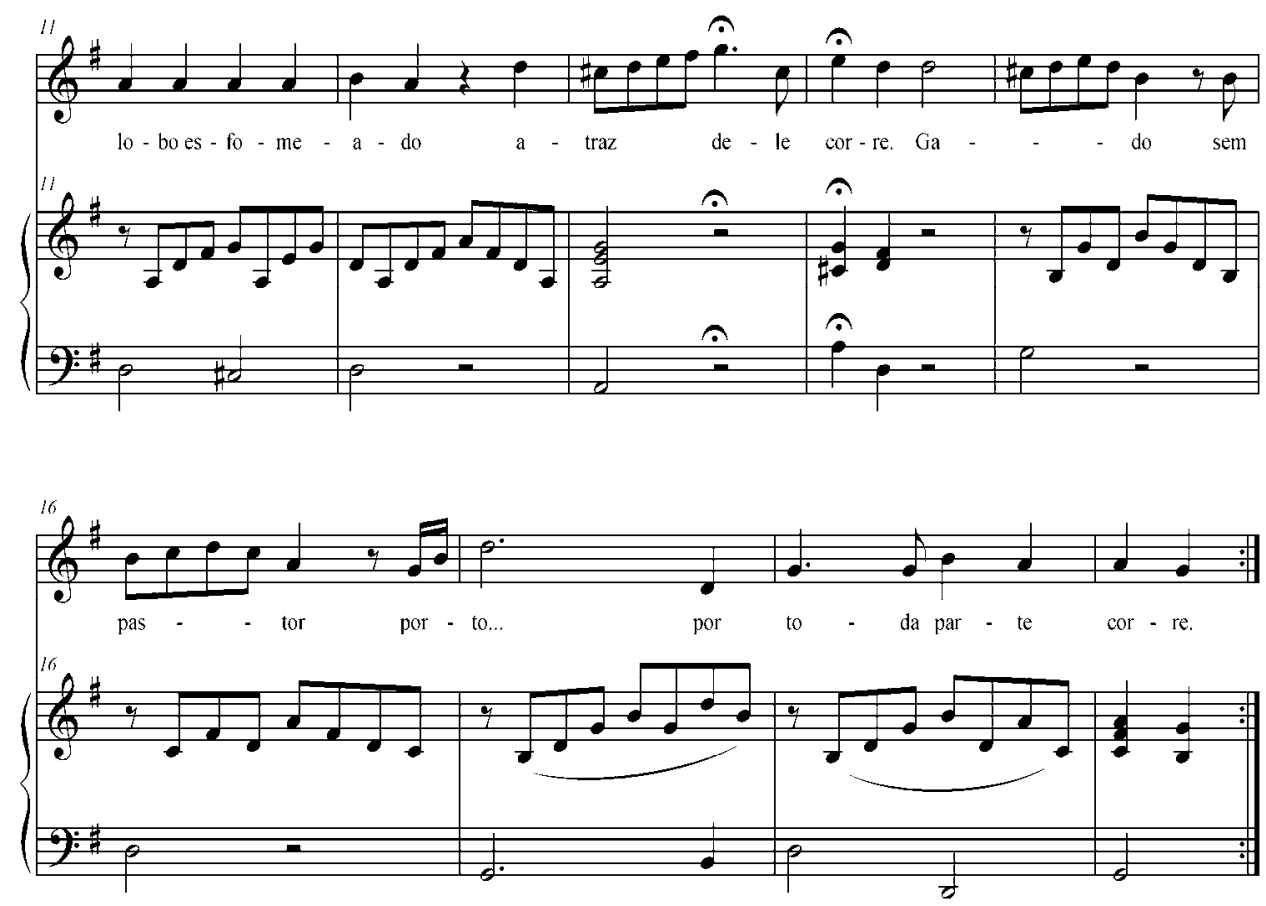

Perdi o rafeiro (Spix \& Martius, 1981[1821])

Encontramos na Coleção Curt Lange do Museu da inconfidência de Ouro Preto a modinha Quando na verde campina, um dos raros exemplos de uma cantiga do século XVIII. A modinha está dividida em três seções: a primeira seção, $A$, possui apenas uma frase de quatro compassos delimitada por um sinal de reprise $(\S)^{57}$; a seção $\mathrm{B}$, com doze compassos, é formada por três frases de quatro compassos cada, sendo que as duas primeiras se comportam como uma espécie de desenvolvimento: a primeira efetuando cadência suspensiva em lá (c. 9), dominante de ré menor, portanto, tônica relativa e a segunda (c. 13) retornando a fá maior; além disso, o fato de estarem construídas com motivos semelhantes, conferem-lhes certa periodicidade. A frase terceira desta seção funciona como uma espécie de extensão reiterativa da tonalidade de fá maior, à guisa de codetta (cc. 14-17). A terceira seção desta modinha, onde figura a tradicional síncope característica, funciona como uma coda.

\footnotetext{
${ }^{57}$ Manuel Morais destaca o uso do mesmo sinal em várias modinhas exatamente com valor de repetição denominados "esse": Muzica escolhida da viola de Lereno, (BARBOSA, 2003, p. 39).
} 
Quando na verde campina

Estudo e ediç̧ão
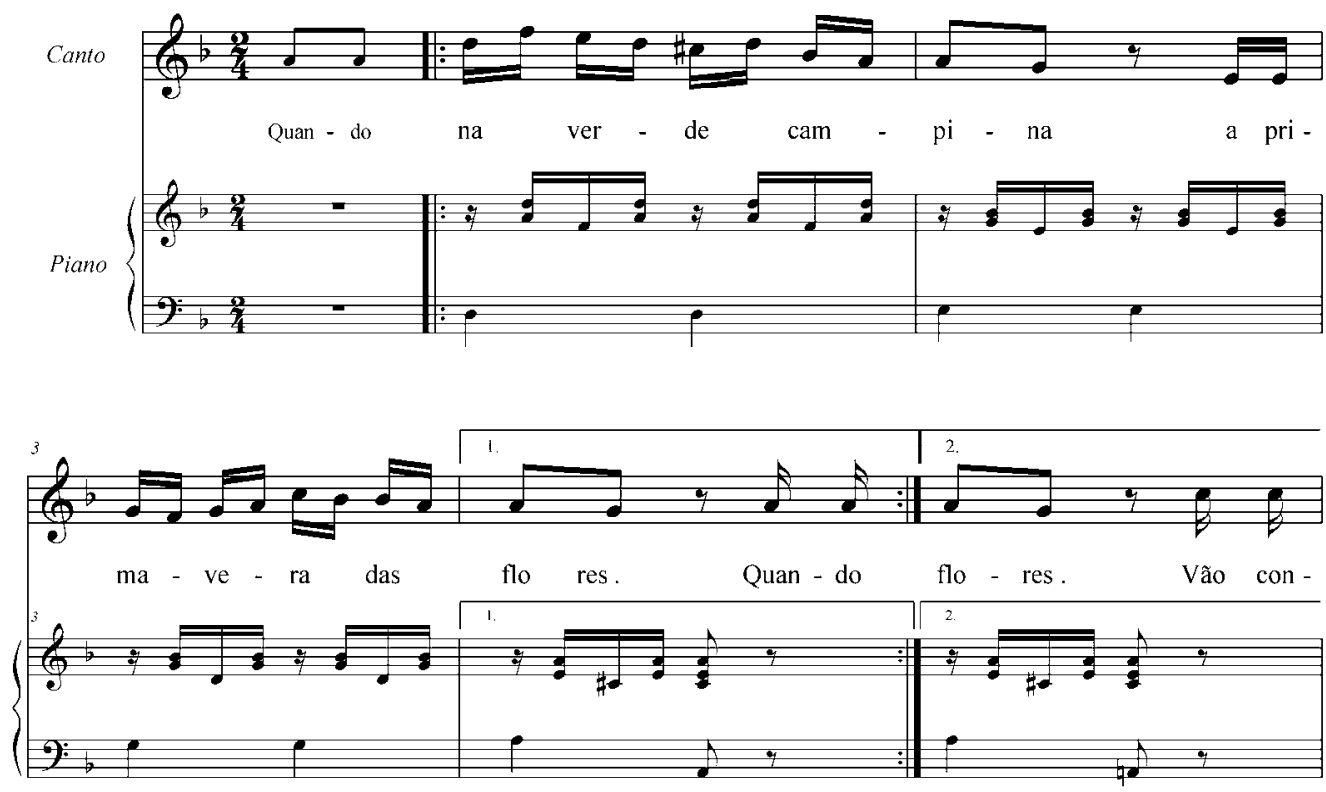

[piu mosso]
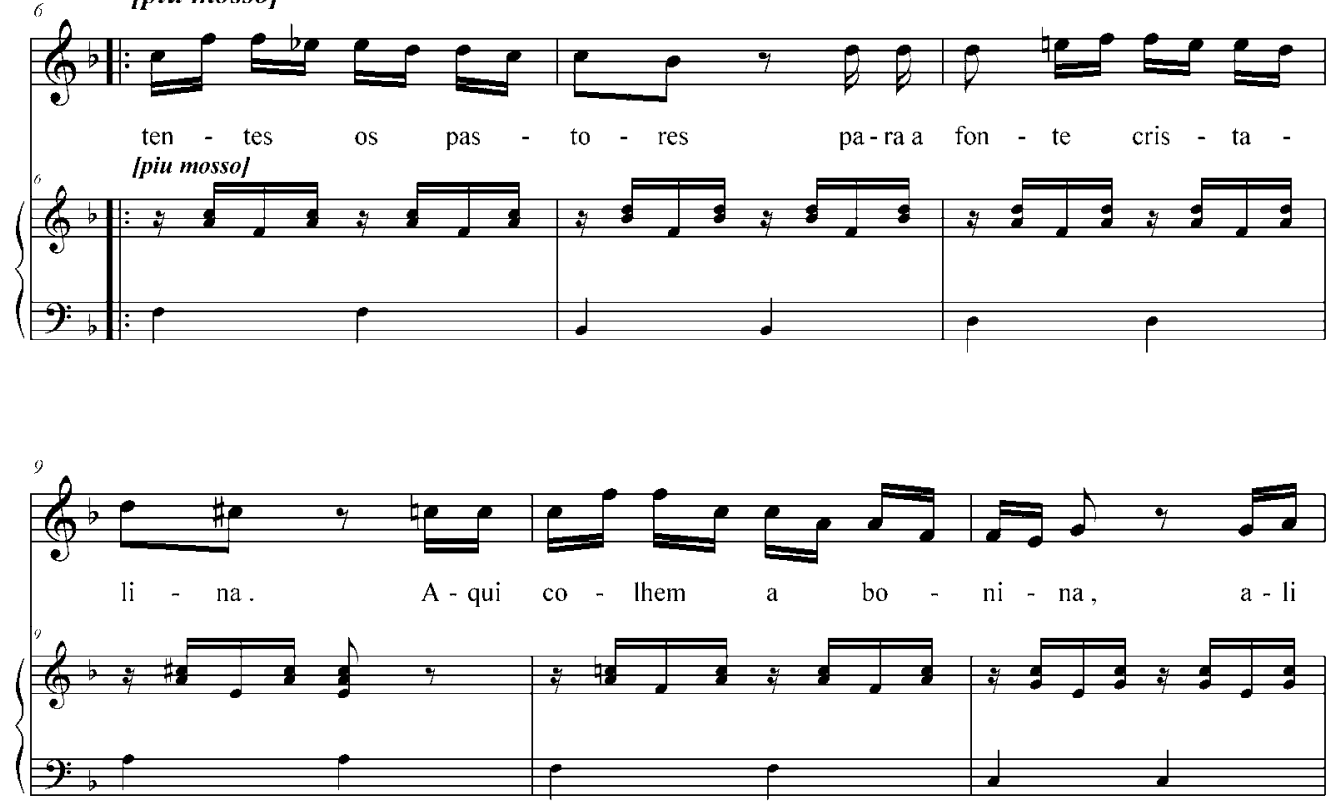

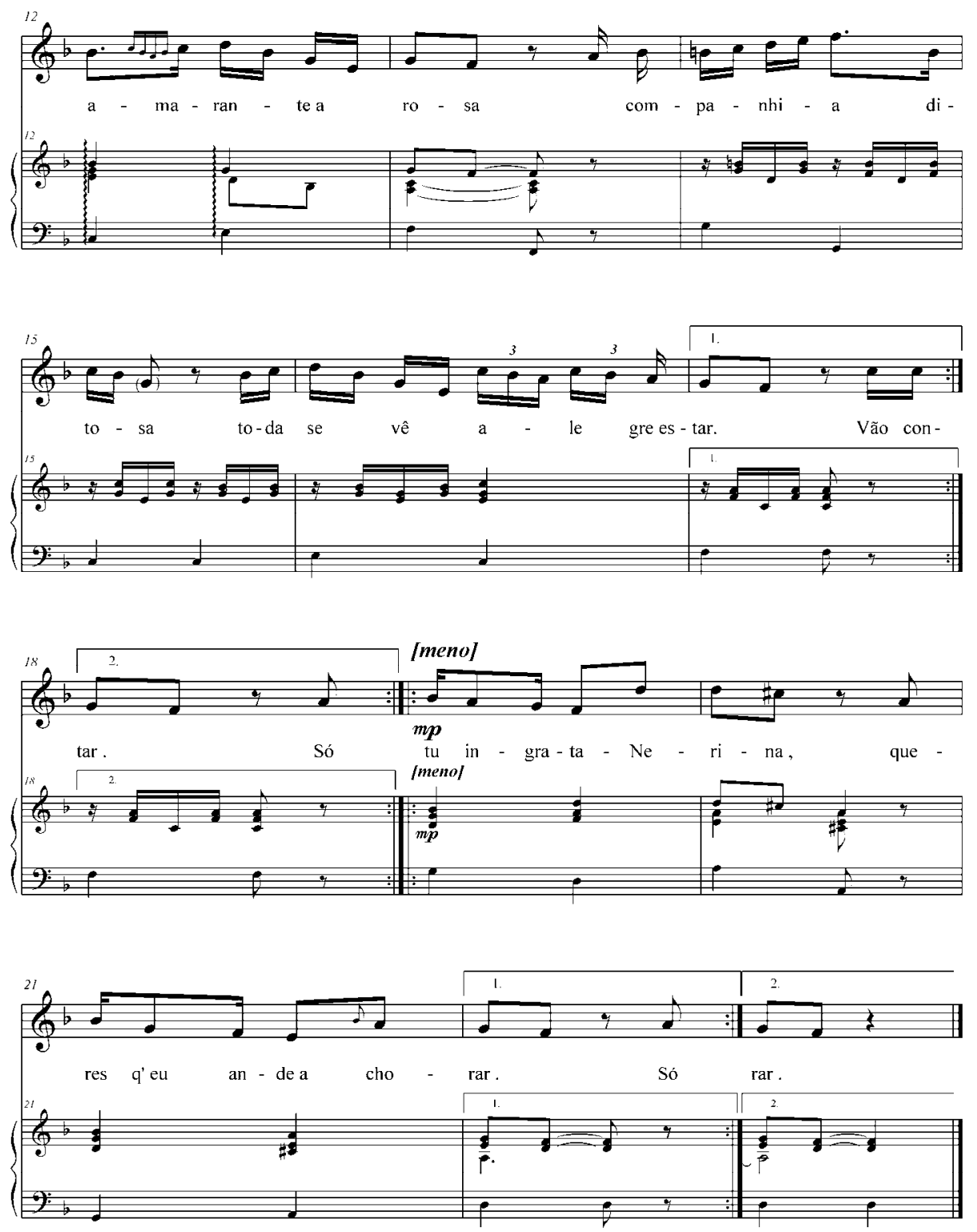

Quando na verde campina (Arquivo Curt Lange, MIOP)

Independente dos esquemas formais variados, a opção fraseológica, formada por motivos, semi-frases e frases articuladas e periódicas, indica uma maior proximidade com o estilo clássico. Outra questão, a presença da síncope também em modinhas, sobretudo no manuscrito Modinhas do Brasil, indica 
uma grande proximidade com manifestações da cultura negra já no século XVIII. De qualquer modo, essa questão será discutida mais adiante.

A modinha Ah! Nerina eu não posso (BARBOSA, 20003, pp.: 63-65), uma forma ternária $A B A$ (1-8) que além do estribilho formado pela segunda frase da parte $A$, compassos 4 a 8 , possui um interlúdio com a indicação Assobio de boca, estilizando o canto do sabiá, com extensão de seis compassos. Além disso, todas as frases da parte A (cc.1-8), e o que consideramos de B (cc. 9-12), possuem a extensão de quatro compassos formados por duas semi-frases de dois compassos repetidas. O que consideramos A' (cc. 13-14), possui apenas dois compassos e o estribilho, quatro compassos. Porém se somarmos os dois compassos do A' com o Assobio, que possui seis compassos, teremos uma peça absolutamente simétrica. Só a título de curiosidade, Nerina é uma das musas presentes nos poemas de Domingos Caldas Barbosa; e se levarmos em conta a simplicidade destes versos e a saudade simbolizada no canto do sabiá, "Esta extraordinária modinha, seguramente brasileira", nas palavras de Manuel Morals (Ibidem, $p$. 61), bem poderia ser do Lereno Selinuntino, o "poeta da viola, da modinha e do lundu" (TINHORÃO, 2004).

\section{Ah! Nerina eu não posso}

(Modinha)
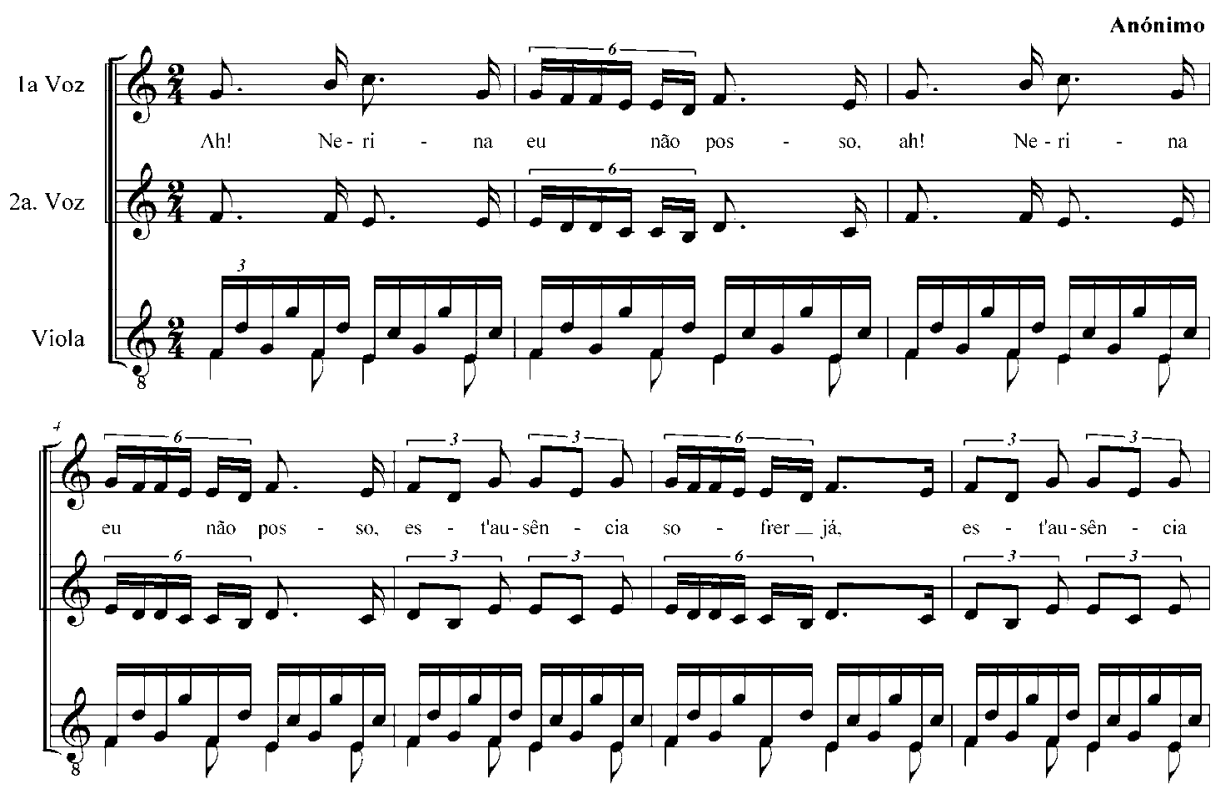

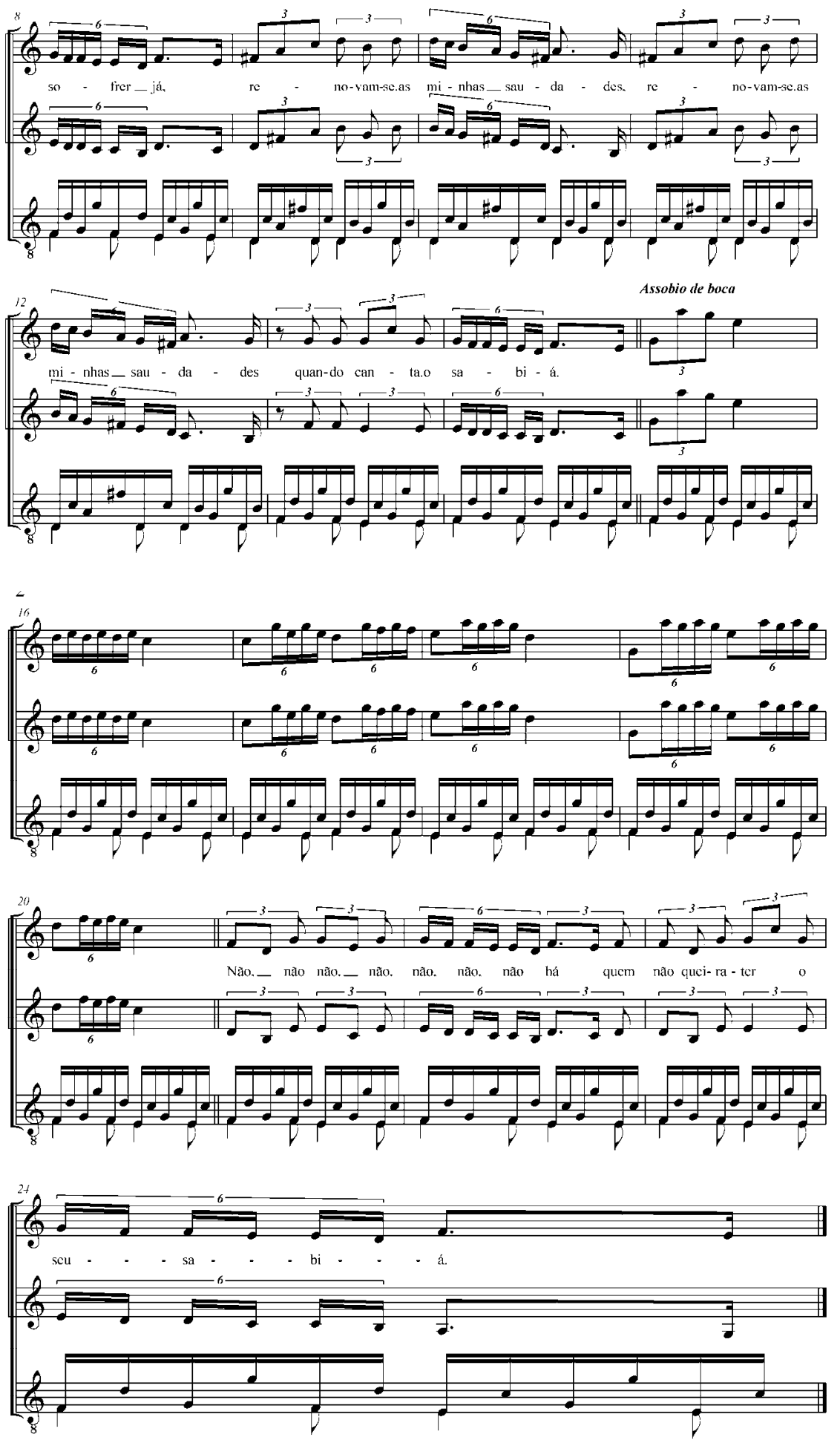

Ah! Nerina eu não posso (MORAIS, 2000)

A forma Da Capo em modinha, também ocorre, porém com menos frequênica. Como exemplo, podemos citar a modinha Amor, eu venho pedir-te do códice Muzica escolhida da viola de Lereno. Nesta cantiga, como em outra 
desse mesmo códice, a modinha Hei de oferecer a Amor, apesar da indicação de Da capo no final da segunda seção, não encontramos a indicação Fine. De qualquer modo e concordando com Manuel Morais, o Fine, em se tratando de uma forma ternária, deve ser efetuado ao final da primeira seção (BARBOSA, 2003, p. 112)

\section{Amor, eu venho pedir-te}

(Modinha a duo)
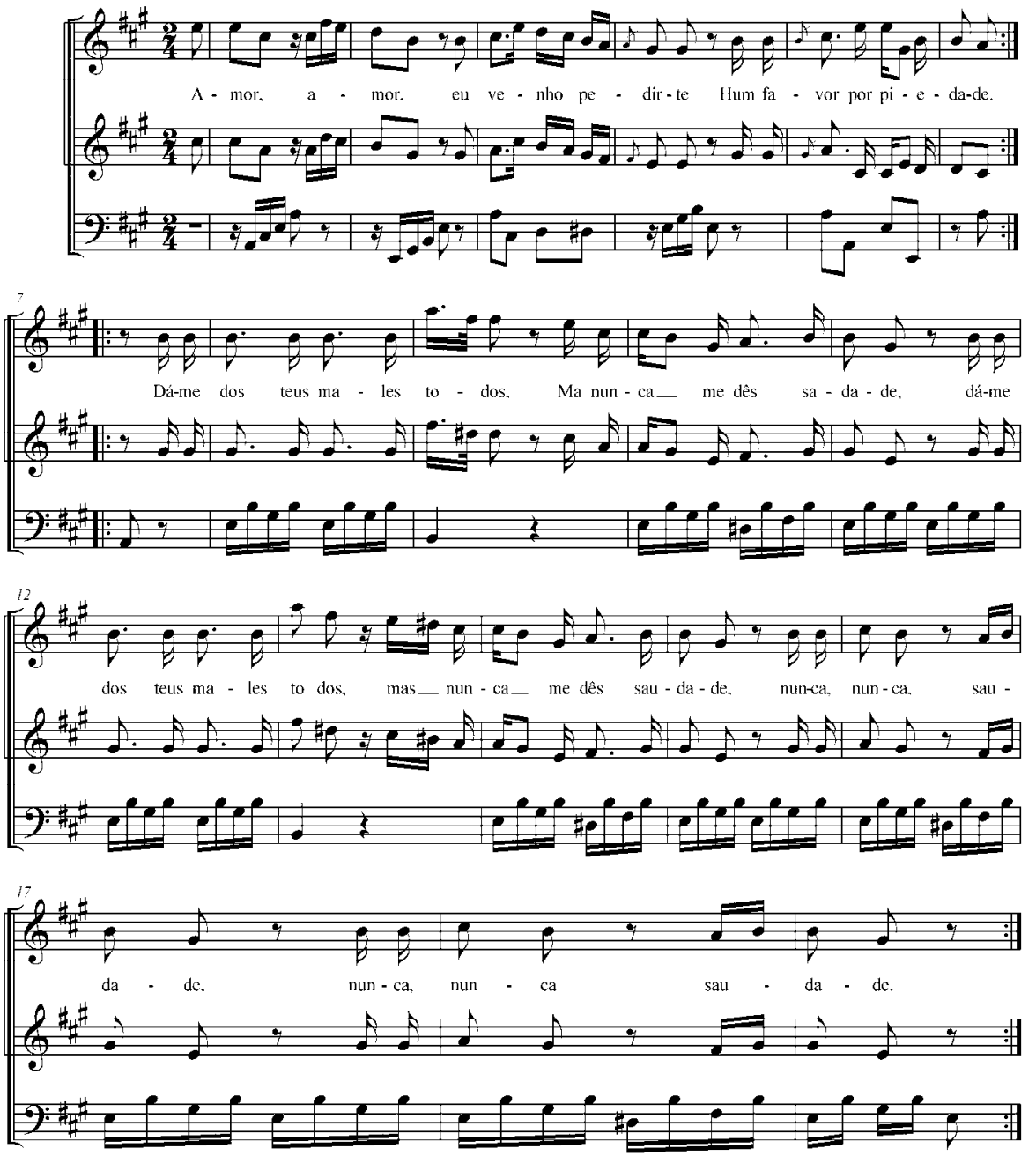

Amor, eu venho pedir-te (BARBOSA, 2003)

Há modinhas ternárias, onde a terceira seção é o estribilho. É o caso da modinha É delícia ter amor (LIMA, 2001: 153155). Nesta modinha, as seções estão claramente indicadas por ritornelli: a primeira seção é formada por duas frases, a primeira de quatro compassos (cc. 1-4) e a segunda de cinco (cc.5-9). 
A segunda seção, iniciando com uma frase nova na tonalidade relativa (sol maior) de quatro compassos (11-14) para na segunda frase (cc. 15-20) retomar uma variação da segunda frase da primeira seção. A terceira seção, estribilho, disposta em uma grande frase de oito compassos. Desta forma, o esquema formal dessa peça poderia ser disposto: ||: A :|| B A' || C:||.

\section{É delícia ter amor}
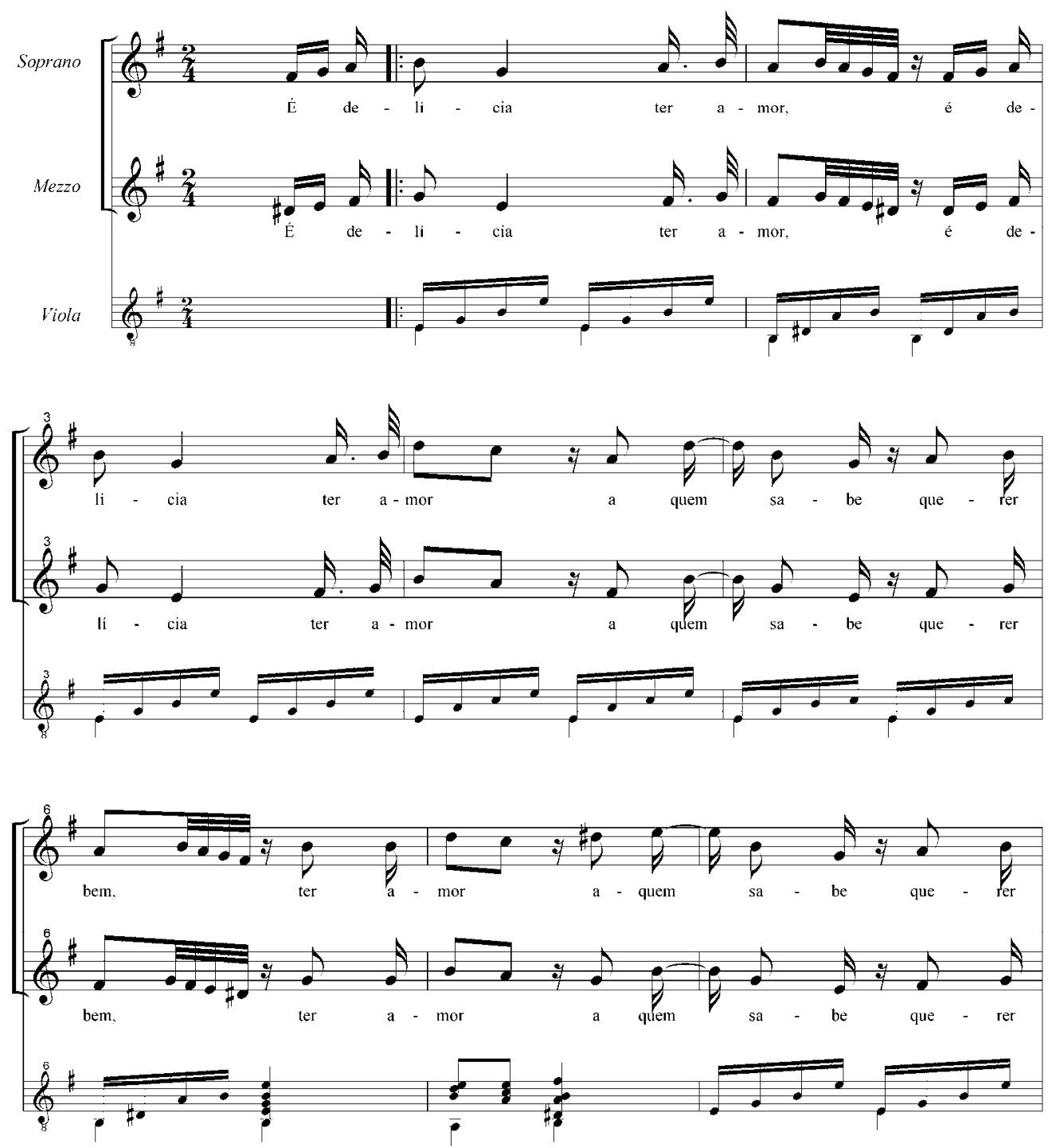

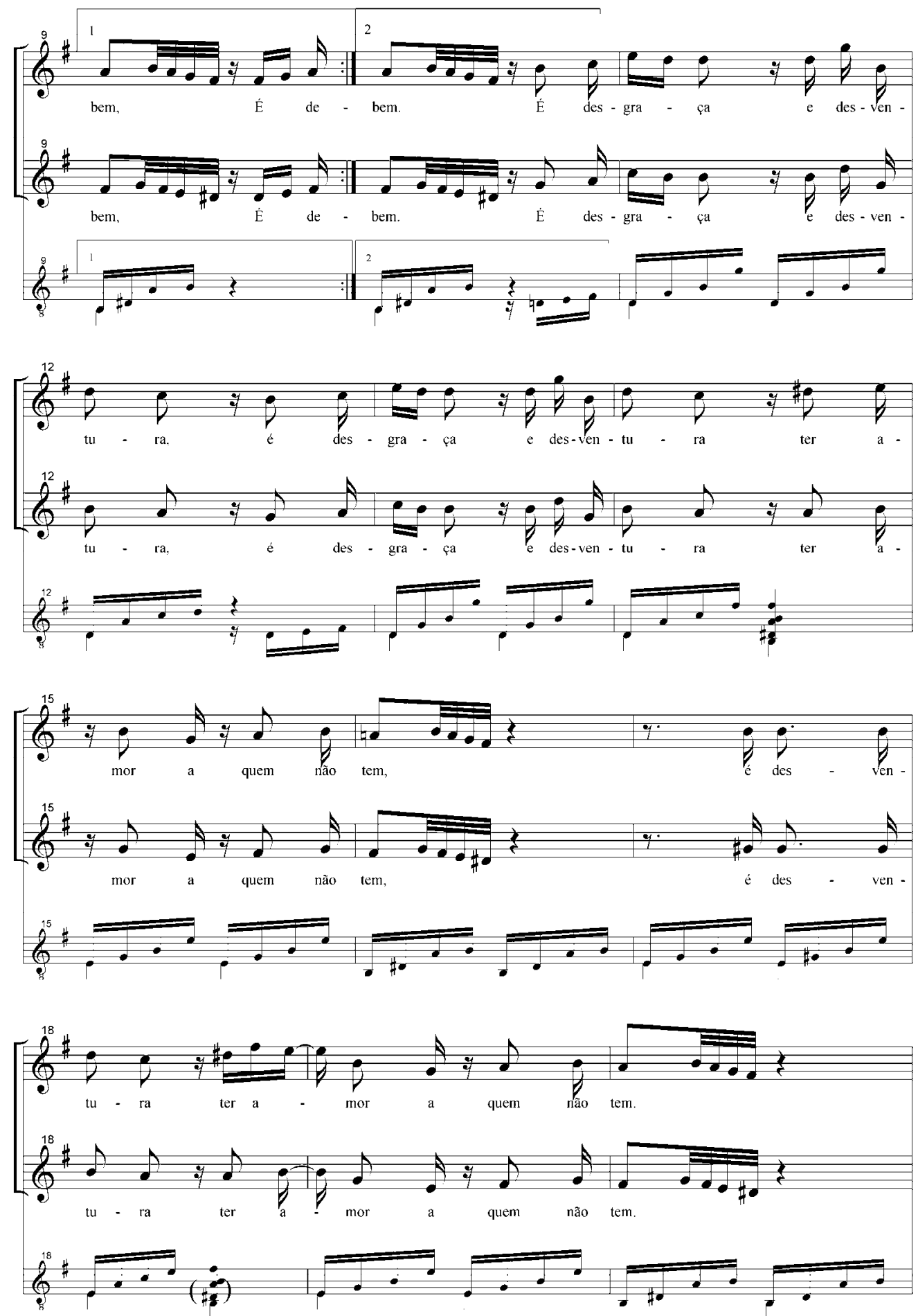

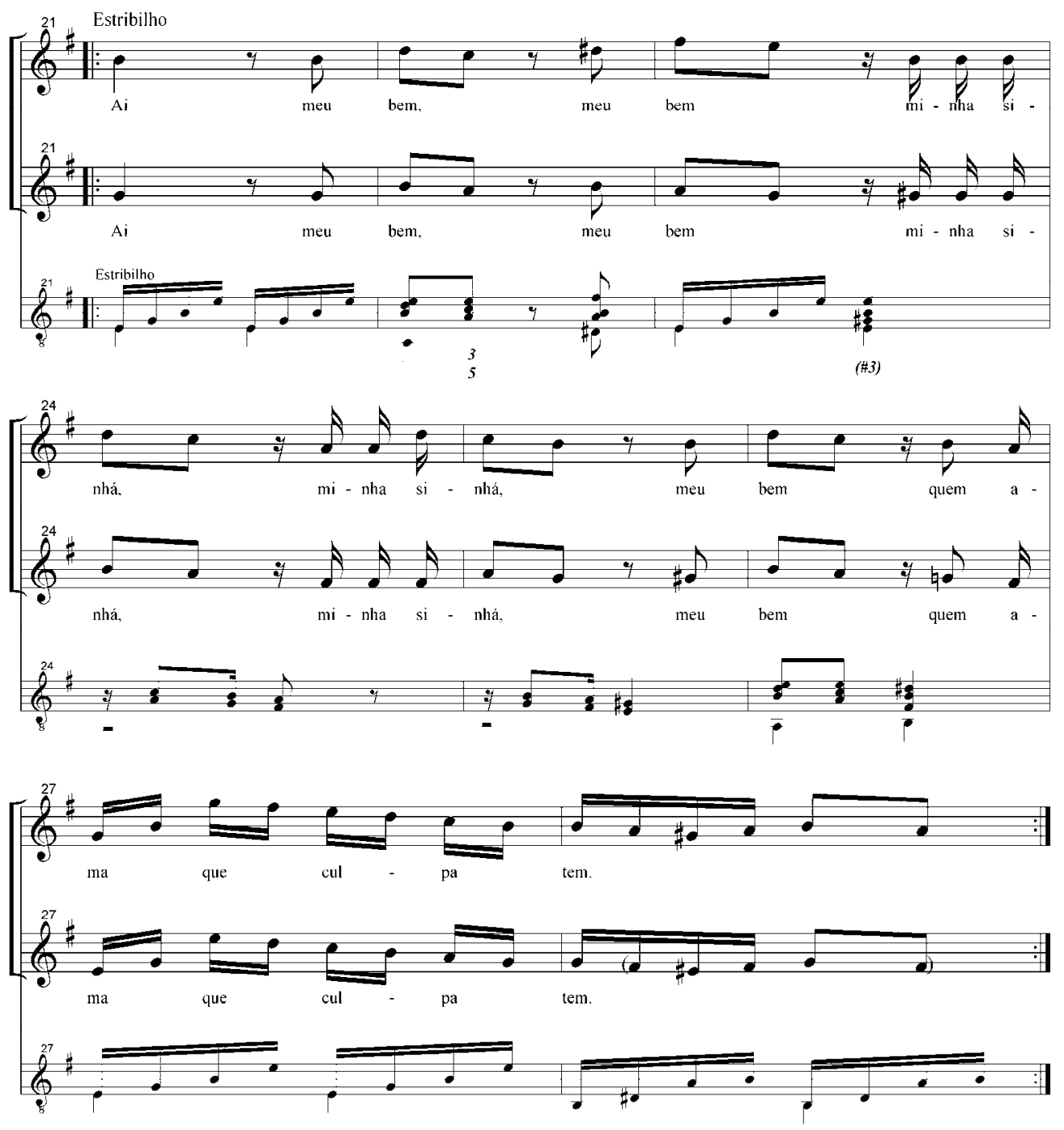

\subsubsection{Belcantismo e canto natural}

A influência da ópera nas cantigas de salão será bastante marcante nessa época, como podemos perceber em modinhas compostas por músicos profissionais para cantores, se não profissionais, com muito boa formação musical. Como é o caso da modinha Hei de amar composta em fins do século XVIII pelo tenor Giuseppe Forlivesi, integrante "da companhia italiana do teatro da Rua dos Condes" (MORAIS, 2000, p.55): 


\section{Hei-de amar a quem me ama}
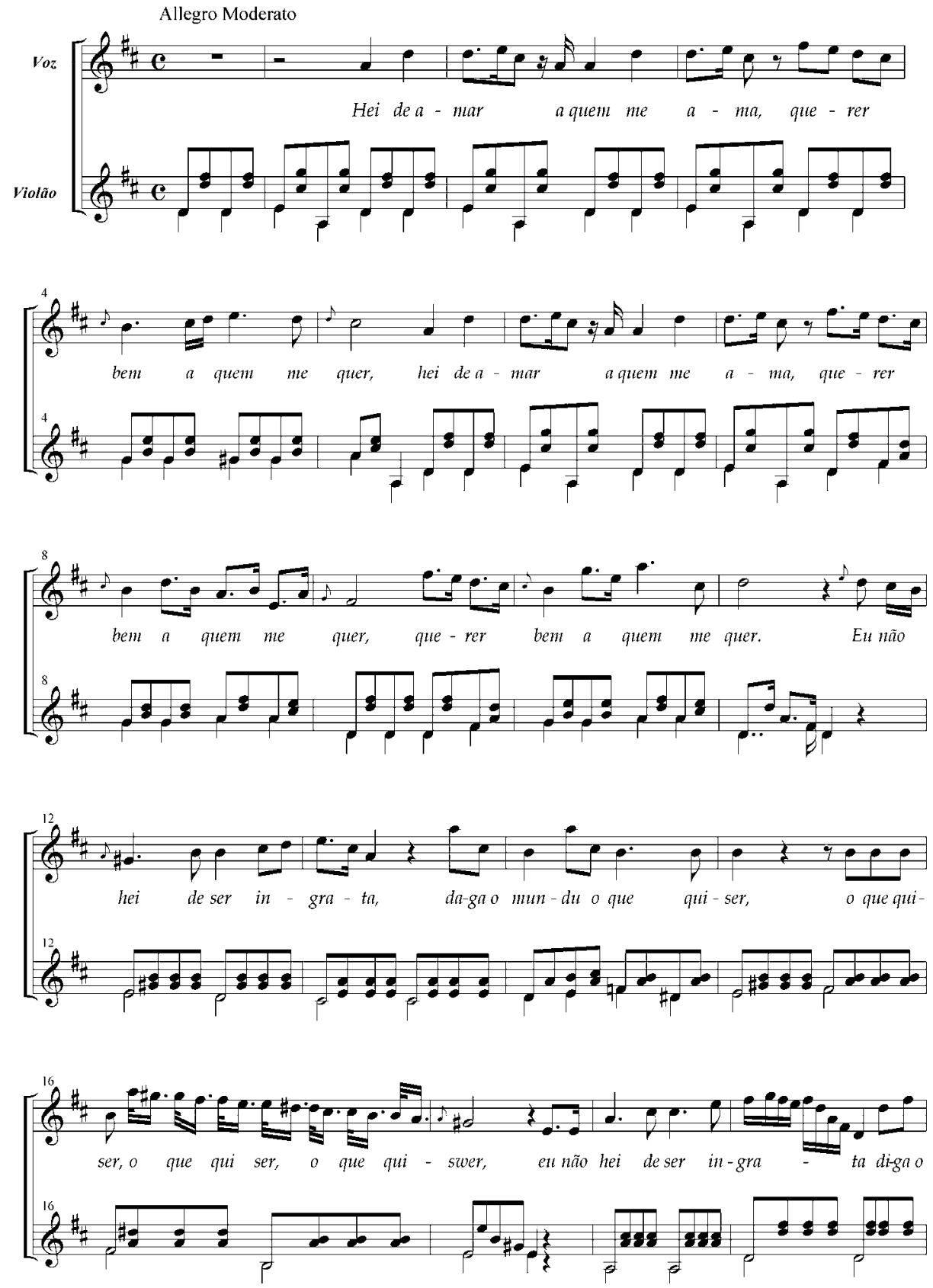

Hei de amar, (MORAIS, 2000)

Nesta modinha, além da extensão que exige um excelente domínio vocal por parte do intérprete, saltos do agudo para o grave (c.13-14), articulações rápidas, coloraturas e notas de passagens, acusam sua ligação com as árias 
de ópera belcantistas. Também a modinha de José Maurício Nunes Garcia (1767-1831), apesar de sua menor dimensão e tessitura mais comportada, as coloraturas, notas de passagem e pequenos melismas presentes na primeira seção da peça, apontam a mesma influência: o fato de a primeira modinha ter sido composta por um tenor da companhia de ópera italiana, e a segunda, por José Mauricio, mestre de capela de dom João VI, indicam que foram efetuadas para profissionais com alto preparo musical ou até talvez para algum dos castratti que vieram ao Brasil na ocasião da vinda da corte (MONTEIRO, 2008; PACHECO, 2008). Nesse sentido, um alto padrão técnico nas interpretações, fazia seguramente parte do espetáculo, seja dentro da corte ou nos teatros para a classe dominante, e o modelo barroco da exibição do eu (CARVALHO, 1999), a nosso ver, ainda estava vigente.

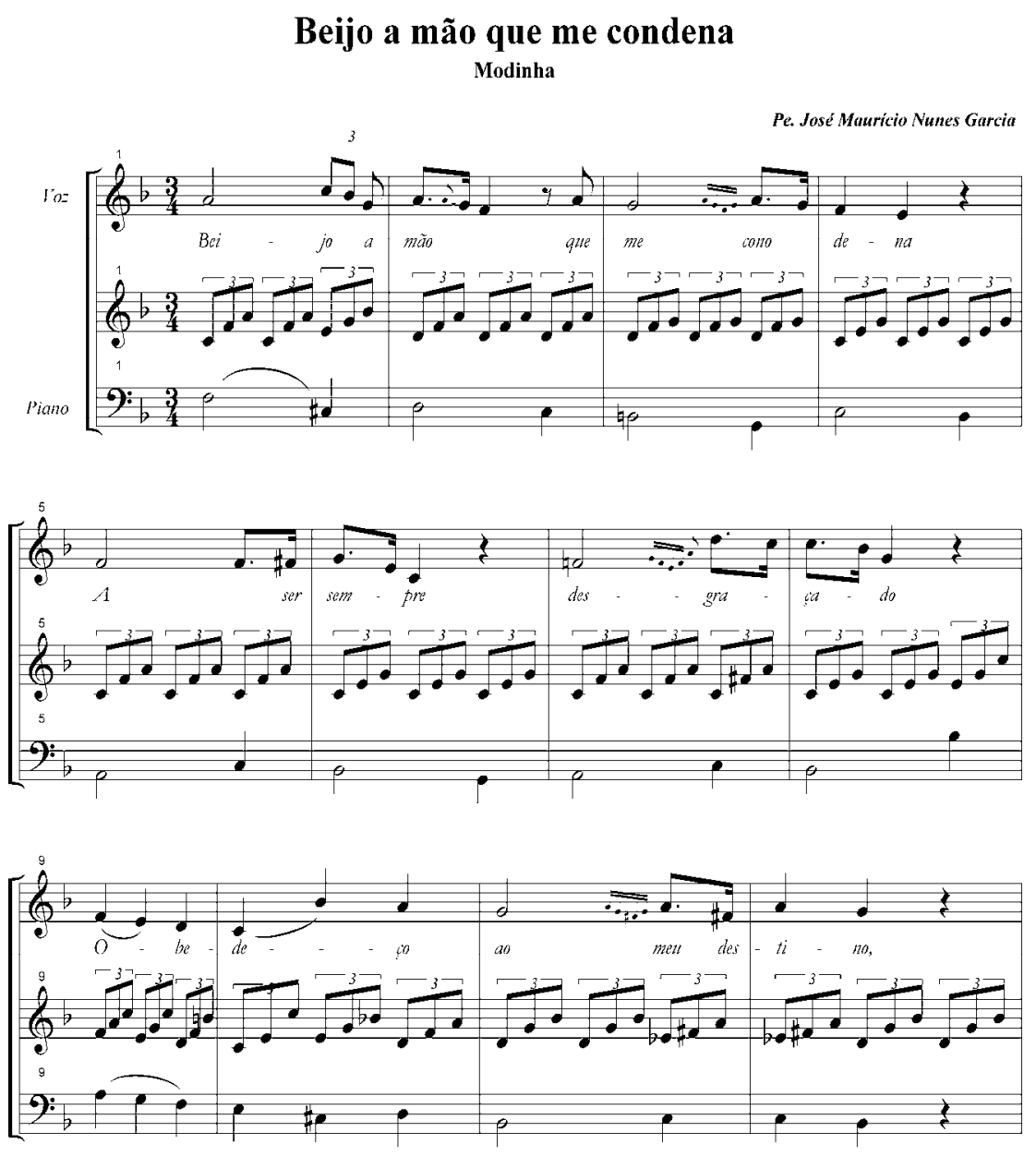



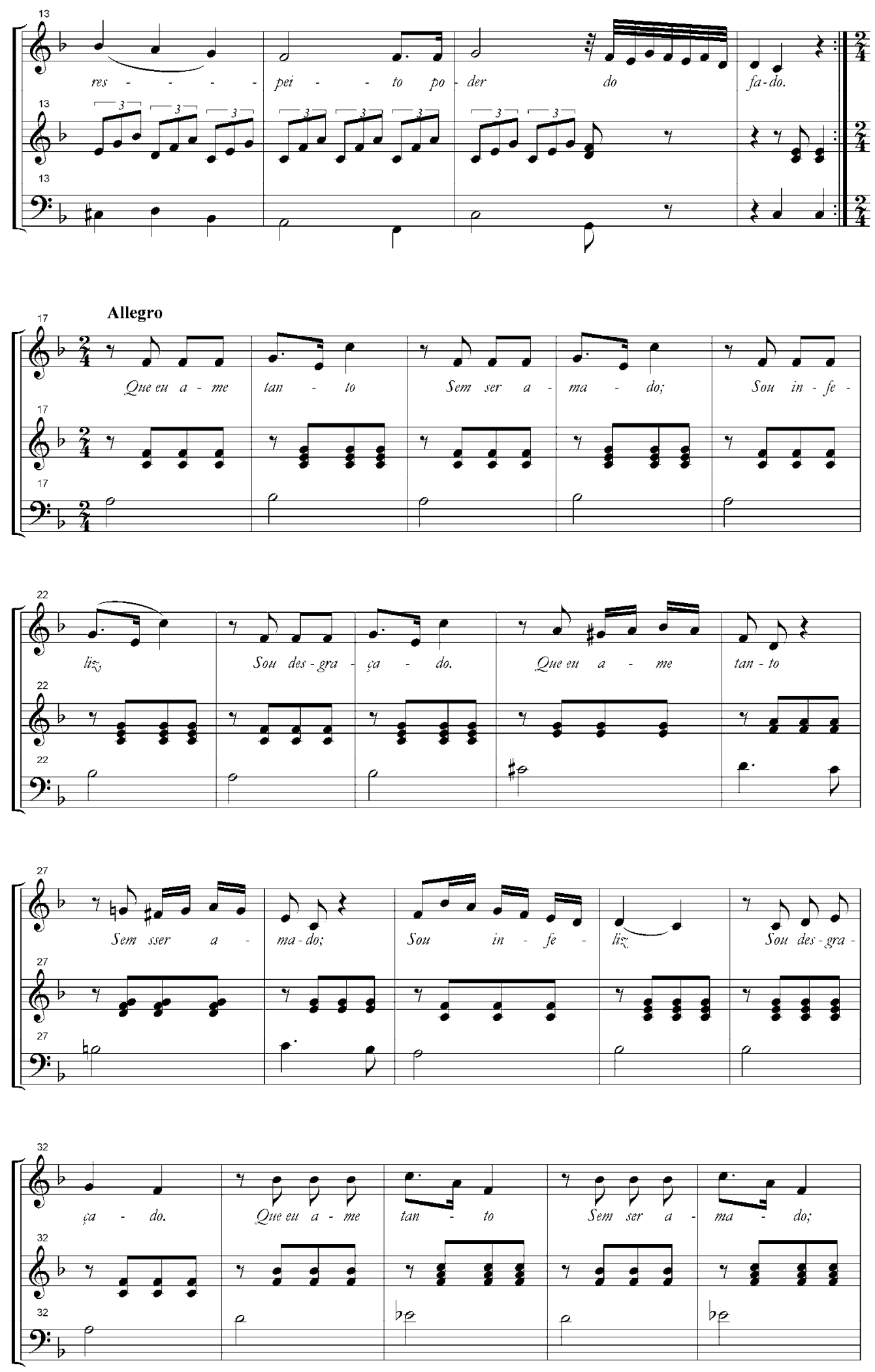

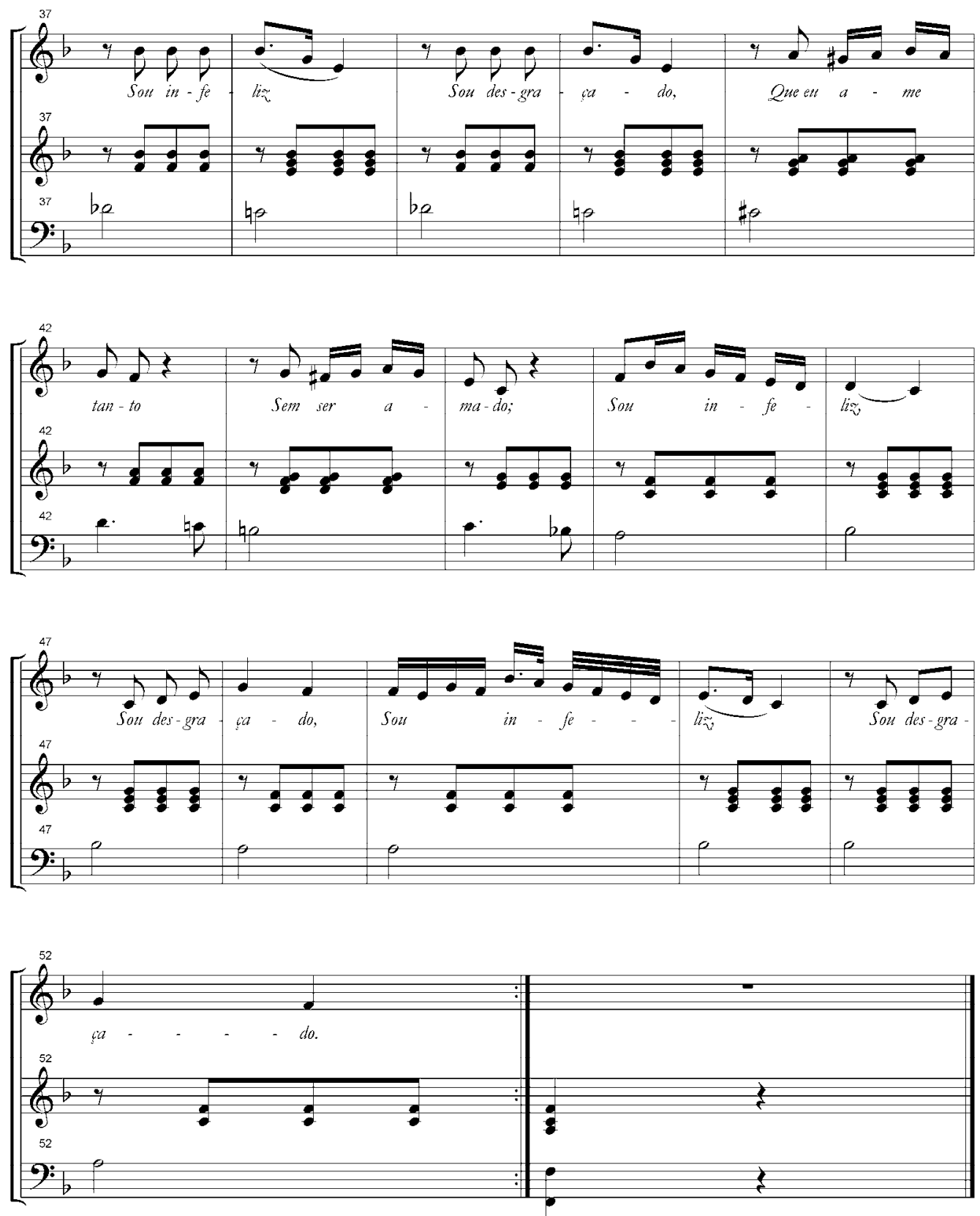

Beijo a Mao que me conden, José Maurício, Biblioteca Nacional - RJ, BR.

\subsubsection{Arcaísmo barroco}

As três últimas modinhas do códice Modinhas do Brasil, Estas lágrimas sentidas, Ausente, saudoso e triste e Não pode a longa distância, tanto em suas opções formais como quanto na opção fraseológica, e configuração 
harmônica, conservam ainda uma proximidade com o estilo barroco. O primeiro aspecto a ser destacado, é a opção harmônica: "ritmo harmônico mais intenso, baixo cantante (melodicamente desenvolvido) e modulações curtas" (LIMA: 2001: 34).

\section{Estas lágrimas sentidas}
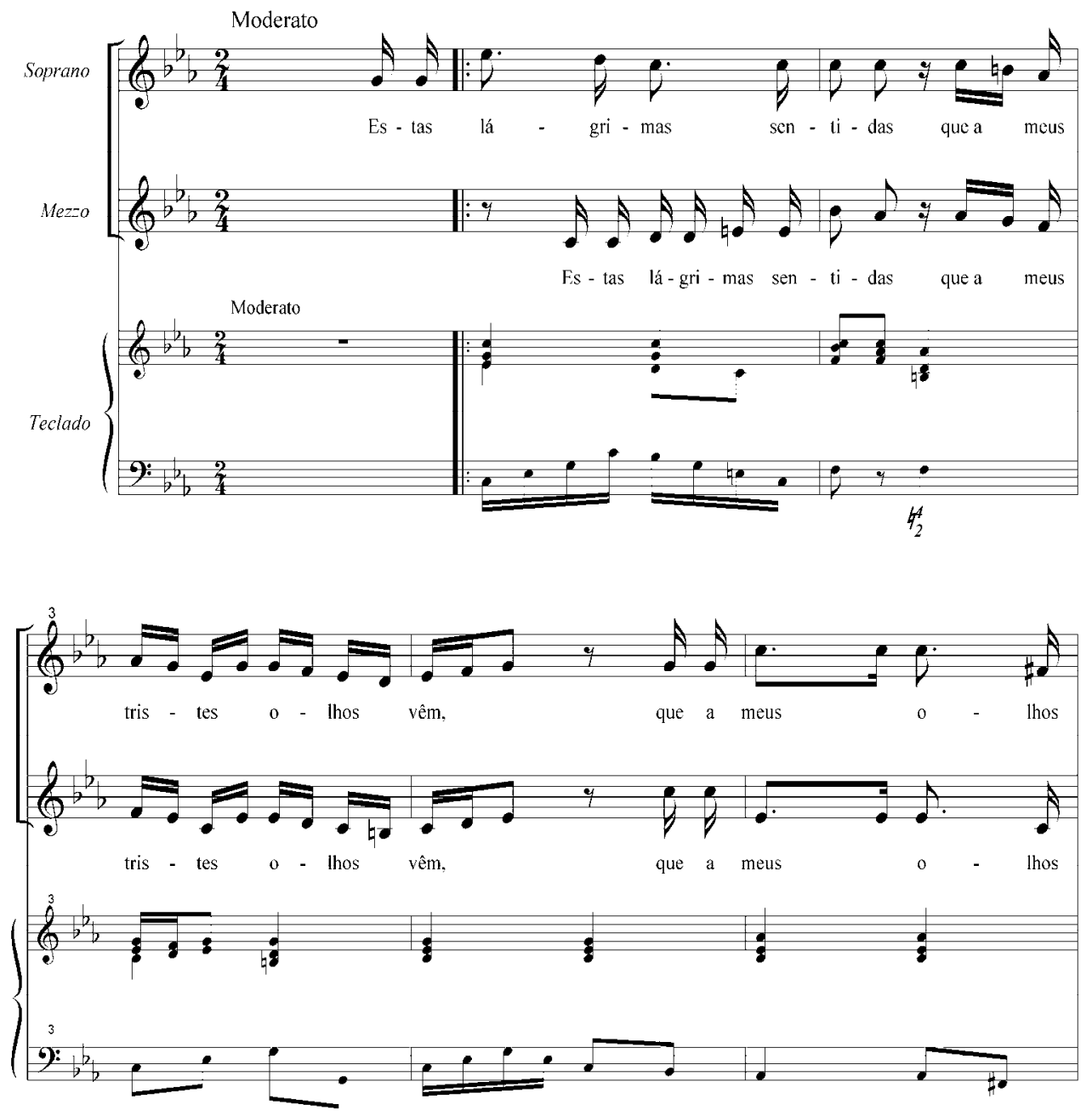

Estas lágrimas sentidas (LIMA, 2001)

Também na questão formal, estas modinhas não seguem os padrões clássicos relacionados com a repetição fraseológica e construção de períodos a fim de construir formas simétricas binárias ou ternárias; mas ao contrário, as frases e formas estão mais relacionadas com o sentido do texto e a curvatura da harmonia em estilo barroco. 


\section{Não pode a longa distância}
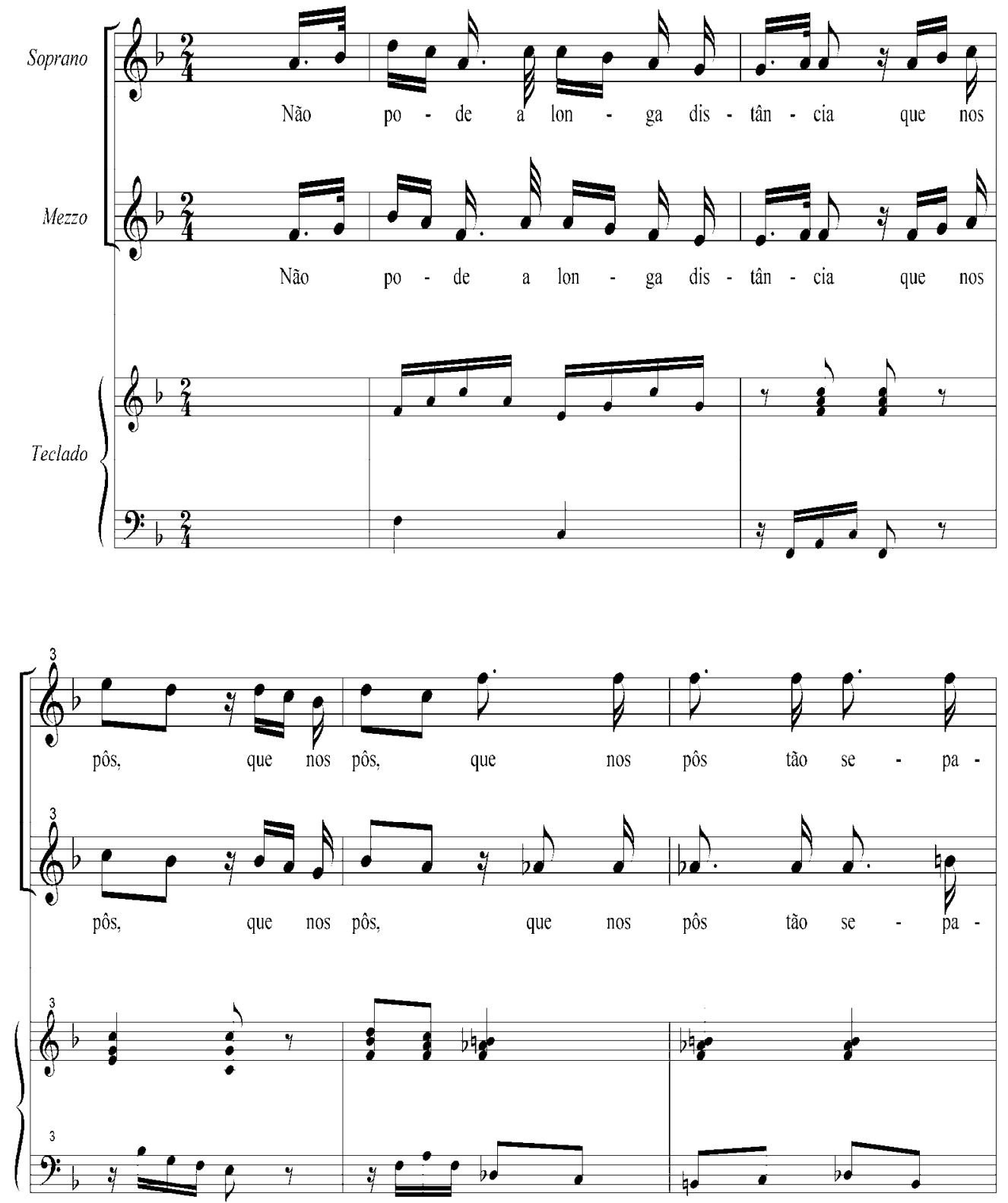

Não pode a longa distância (LIMA, 2001)

É evidente que a intenção desse texto não é efetuar uma análise exaustiva de todas as formas que podem assumir a modinha e o lundu no século XVIII, e uma possível taxonomia tipológica definitiva, sobretudo porque 
não cremos nem em estruturas estáticas e nem numa teoria normativa; mas é nosso desejo, sim, efetuar uma discussão que leve em consideração como o formalismo do século XVIII se manifesta não só na busca de simetria, expressa na periodicidade, seja em sua macro-forma ou seções internas; mas também na variedade e liberdade que as frases e formas poderão assumir, sobretudo, ao utilizar-se de recursos como variação e extensão fraseológica, expressas na incalculável riqueza formal, para além de esquemas formais estáticos. E tais características, como vimos, estão presentes em modinhas compostas entre o século XVIII e a primeira metade do século XIX, e nos lundus como veremos, enfatizando uma identificação com o que entendemos por estilo clássico.

\section{2. O enigma do lundu}

\subsubsection{O lundu, sua iconografia, sua música.}

O lundu, como discutimos acima, foi elaborado a partir de elementos coreográficos e musicais advindos das várias culturas que participaram da formação da sociedade luso-brasileira em fins do século XVIII: elementos coreográficos, como os estalidos dos dedos à guisa de castanholas, a alternância das mãos ora na testa, ora nas ancas, e os movimentos nas pontas dos pés que nos remetem aos passos do fandango espanhol, dança que teve grande penetração na América Latina, tanto espanhola quanto portuguesa, no século XVIII.

O requebro das ancas, outro elemento que participa da coreografia do lundu, juntamente com um movimento circular dos quadris, tem origem nas culturas negras trazidas para a colônia brasileira (MUKUNA, 2006). Porém, um elemento de importância vital para o lundu, ou outras danças de linhagem africana, e que será uma das mais citadas características das danças de origem negra nestas terras, é a umbigada (MUKUNA, 2006, pp. 80-85). Este movimento consiste no ato dos dançarinos, no auge de sua expressividade, chocarem o ventre, um contra o outro, na altura do umbigo.

Mas o que nos interessa neste exato momento, é que os dançarinos dançam ao som de alguma música. E o que nos sugerem os escritos da própria época, é que a sonoridade que acompanhava tão "venturosa" dança era composta por instrumentos de percussão, juntamente com palmas de mãos, aliados, instrumentos de cordas dedilhadas, tais como viola de arame, guitarra inglesa ou francesa (MORAIS, 2000, p. 20). Estes, no caso de haver mais de um instrumento, podiam efetuar acordes em 
arpejos, tocar por pontos (RIBEIRO, 1789) ou rasgueados que marcassem o ritmo padrão do lundu; bem como tocar alguma melodia que pudesse servir de tema para futuros improvisos.

Podiam ser usados, evidentemente, instrumentos melódicos, tais como a flauta, presente na litografia de Jean-Baptiste Debret As distrações dos ricos depois do jantar, onde um negro encostado a uma coluna toca uma flauta enquanto um branco tange um cistre, ou guitarra portuguesa (MONTEIRO, 2008, p. 167), denominado pelo pintor como substantivo genérico de violão (STRAUMANN, 2001, p. 58); ou a rabeca/violino presentes na aquarela Begging for the festival of N. S. D'Atalaya (A.P.D.G., 1826, p. $285)^{58}$. Estes dependiam não só de sua disponibilidade, mas também de sua fácil portabilidade, já que essas manifestações podiam ocorrer em um terreiro ao largo das cidades e vilas. Junte-se a esse fato, o poder aquisitivo dos atores sociais em questão, pois adquirir um instrumento demanda recursos econômicos; e isso está consequentemente condicionado às possibilidades individuais. De qualquer modo, ao revisitarmos algumas das gravuras do início do século XIX, principalmente aquelas efetuadas por Jean-Baptista Debret (1768-1848) ou Johann Moritz Rugendas (18021858), encontraremos cenas cotidianas onde são exibidos, mesmo que de um modo idealizado e estilizados (ALENCASTRO, 2001, pp. 137-66), instrumentos usados nas performances do lundu.

Retornando à litogravura $A$ distração dos ricos depois do jantar, ao descrever uma cena na intimidade do interior de uma casa de proprietários da classe média, Jean-Baptiste Debret nos apresenta dois instrumentos, uma flauta e outro instrumento que ele denomina violão, mas que se assemelha a um cistre ou à popular guitarra inglesa; mais tarde conhecida como guitarra portuguesa, como comentado acima ${ }^{59}$. No texto pertencente à gravura, o ator nos relata que dominados por uma

"delicada saudade, quintessência da volúpia sentimental, apodera-se então de sua verve poética e musical, que se derrama nos sons expressivos e melodiosos da flauta, seu instrumento predileto, ou ainda num acompanhamento cromático improvisado ao violão, cujo estilo apaixonado ou ingênuo colore sua engenhosa modinha" (Apud, STRAUMANN, 2001, p. 58).

\footnotetext{
${ }^{58} \mathrm{O}$ uso desses instrumentos pode ser atestado não somente por iconografias; mas também em partituras: ver Jornal de Modinhas: www.bn.pt./múisca/manuscritos; ou em relatos de viajantes: ver. SPIX \& MARTIUS, Viagem pelo Brasil. Itatiaia: Belo Horizonte, 1981; também em poesias da época: ver. Nicolau Tolentino em ARAUJO, M. de. A modinha e o lundu no século XVIII. Ricordi: São Paulo, 1963.

${ }^{59}$ Cistre ou citern - cordas metálicas (isso é bom); comentário sobre a questão das nomenclaturas da guitarra, viola, violão, etc. Ver site: http://monsite.wanadoo.fr/ugocetera/page1.html; Atlas de Música. Madrid: Alianza Musica, 2002, pp. 42 e 43. Também na pintura do teto da Igreja de São Francisco de Assis em Ouro Preto, há um instrumento semelhante, mas com corpo abaulado, lembrando um alaúde.
} 


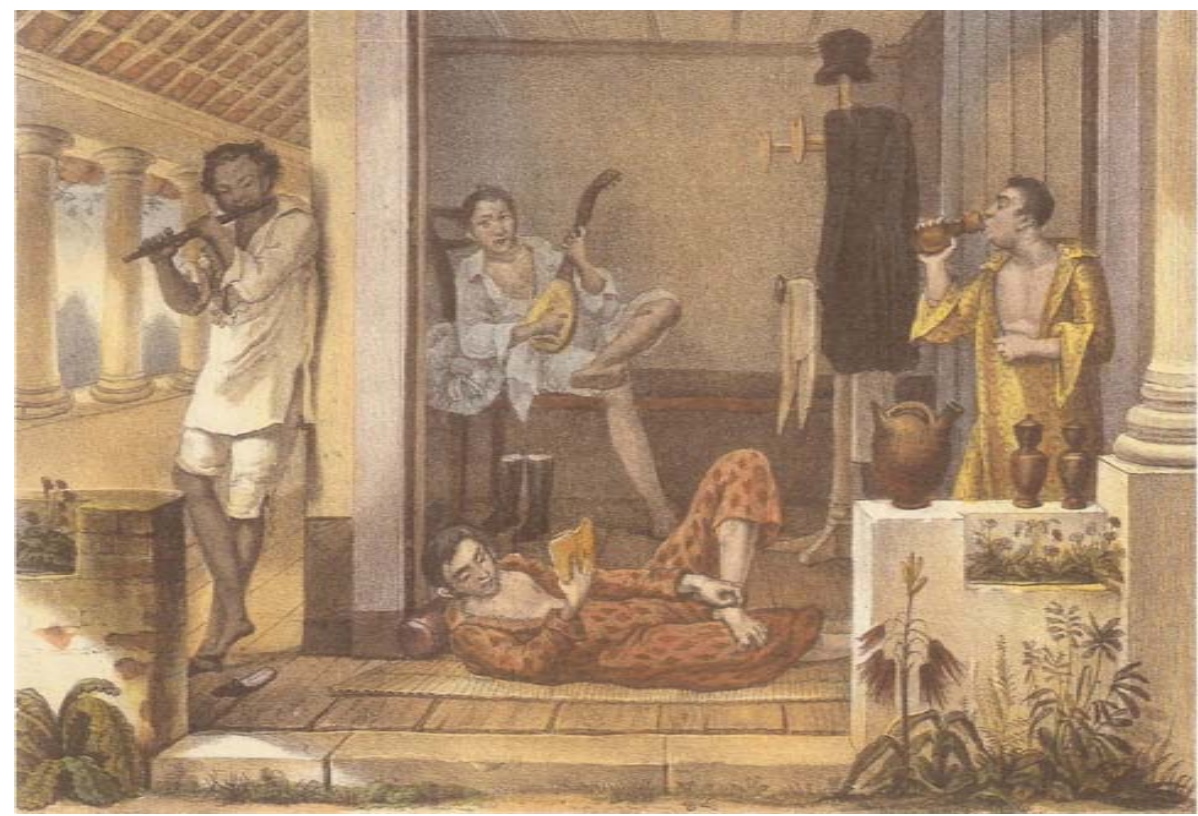

A distração dos ricos depois do jantar, Jean-Baptista Debret.

Já na gravura de A.P.D.G, intitulada Begging for the festival of N. S. D'Atalaya (A.P.D.G., 1826, p. 285), com traços exageradamente caricaturais, são apresentados um bumbo e um violino, enquanto um casal de negros vestido de branco, desenvolve o que parece ser a dança do lundu. O que podemos deduzir, é que o violino tocava a melodia, enquanto o instrumento de percussão efetuava a marcação rítmica.

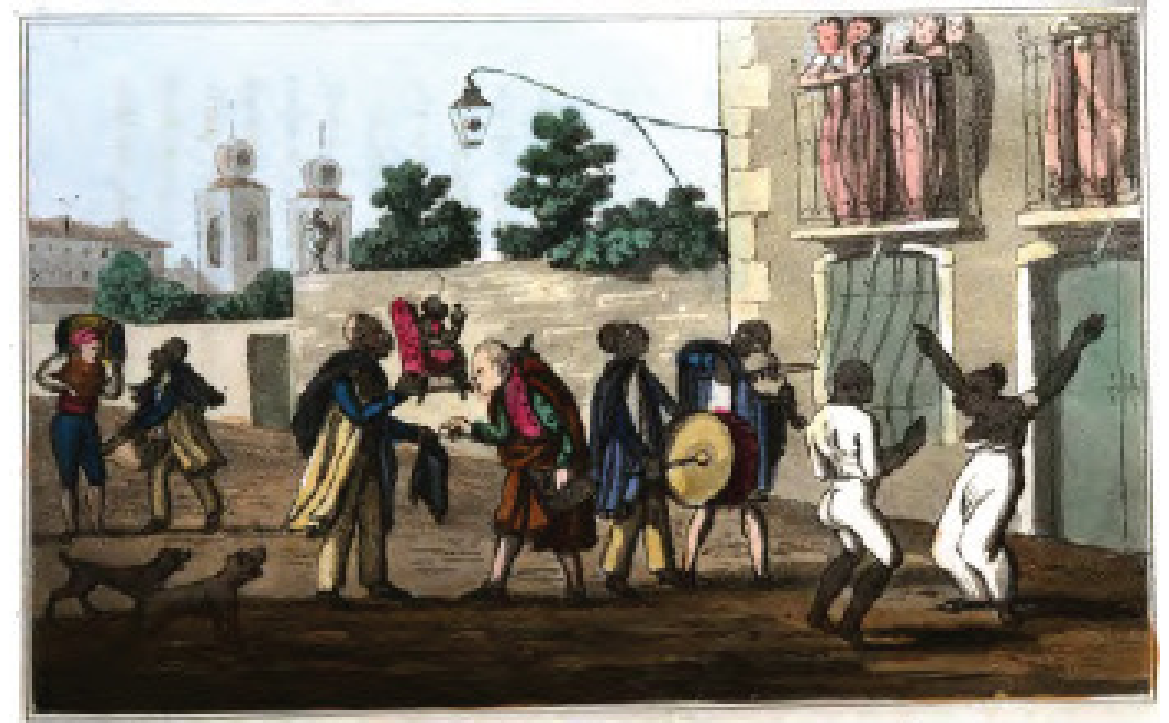

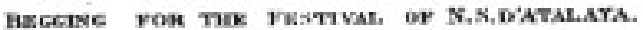

Begging for the festival of N. S. D'Atalay, A.P.D.G. 
Em outra gravura de Rugendas, que descreve uma festa para Nossa Senhora do Rosário - Patrona dos negros (RUGENDAS, 2002, p. 135), vemos outros instrumentos: um negro tocando um bumbo, um outro tocando uma cornamusa, ou gaita de fole, outro tocando uma flauta píccolo e outro com uma calimba ${ }^{60}$ nas mãos. Nesta representação, a presença de instrumentos da tradição negra e européia se associa para o festejo de uma santa já absolutamente sincretizada.

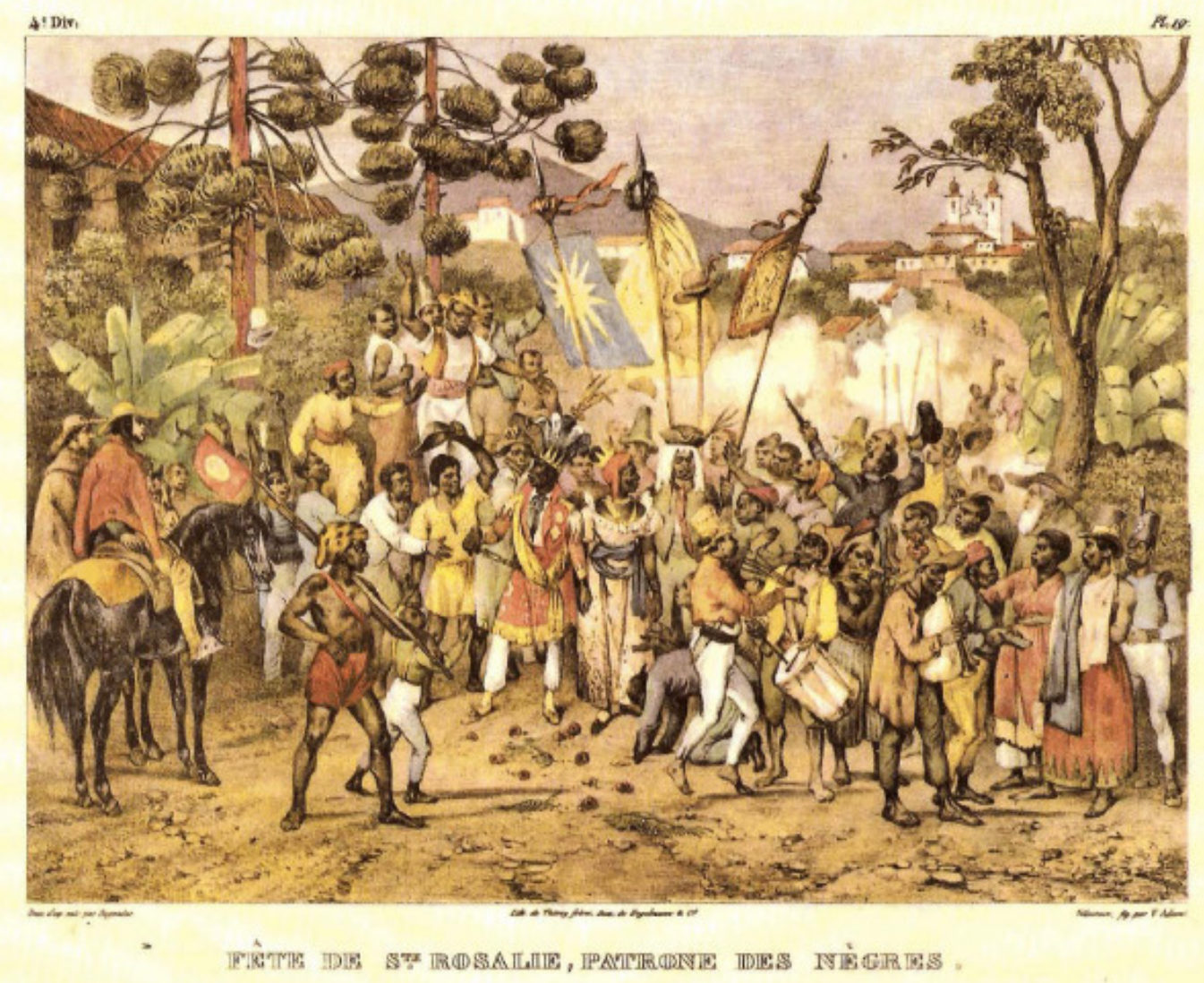

Nossa Senhora do Rosário - Patrona dos negros, Johann Moritz Rugendas.

Outra gravura, de nome Batuque, que se encontra no livro Viagem pelo Brasil de Spix \& Martius (SPIX \& MARTIUS, 1981[1821] - Vol. 1, p. 179), ao apresentar uma cena na mata, além dos casais de negros em um momento anterior ou posterior à umbigada,

\footnotetext{
${ }^{60}$ Calimba ou marimba, instrumento formado por uma cuia de coco ou cabaça e palhetas de metal perfutidas (CARDOSO, 2008)
} 
componente indispensável da dança do lundu, mostra-nos dois instrumentos bastante ligados à tradição popular: um reco-reco e um balafon ${ }^{61}$.

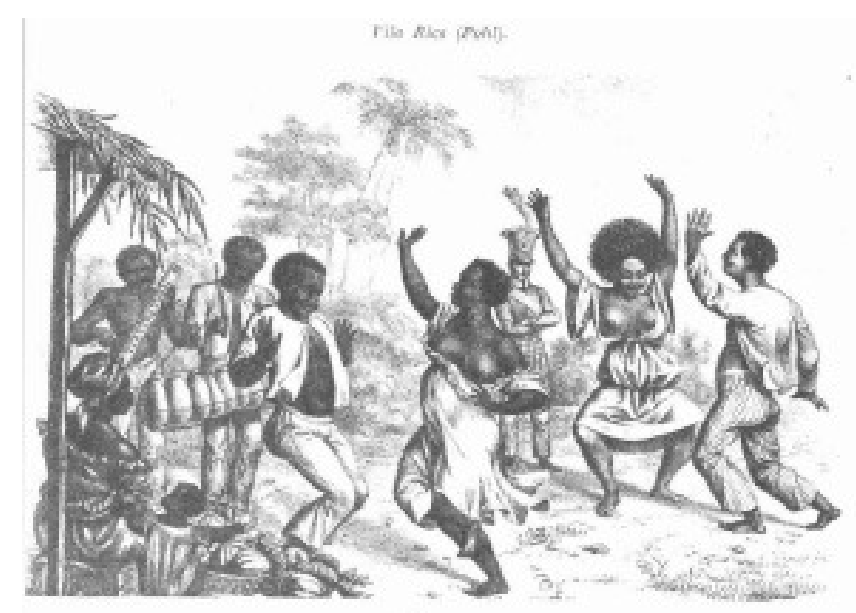

Batuque - Viagem pelo Brasil de Spix \& Martius (1981[1821])

De qualquer modo, a representação dos dançarinos na gravura de Spix \& Martius, assim como na opção figurativa das aquarelas de A.P.D.G. acima comentadas, têm um ar bastante caricatural e, por que não dizer, pejorativo, Evidentemente não é possível desvincular da visão desses dois cronistas da cultura carioca do século XIX certo aspecto elitista, sobretudo quando folheamos os Sketches of Portuguese Life (A.P.D.G., 1826) e nos deparamos com seus comentários, onde a população negra e mestiça, tratada como "ralé" (Cf, cap. 1) nas palavras do cronista inglês que, diga-se de passagem, escondeu-se em uma sigla, não poderia ser tratada com respeito, pois se considerada graciosa e elegante, teria que ser comparada à população branca e livre; e este não era seguramente o caso. Portanto, se nas representações de Rugendas e Debret há uma estilização para o modelo de homem ocidental, clássico; nas duas gravuras acima, a de Spix \& Martius e A.P.D.G. optam pela interpretação inversa, buscando uma representação depreciativa.

Outra questão é que não obstante todas as gravuras pertencerem ao século XIX, essas representações da dança do lundu combinam com a descrição que encontramos na Carta Chilena de Tomas Antonio Gonzaga ${ }^{62}$, portanto anterior à

\footnotetext{
${ }^{61}$ Reco-reco, instrumento de percussão ainda usado nos dias de hoje; Balafon: espécie de marimba feita de cabaça presente na África negra. Fonte: http://portalmarket.com/balafon.html.

62 "Fingindo a moça, que levanta a saia, /E voando nas pontas dos dedinhos, /Prega no machacaz de quem mais gosta, / A lasciva embigada, abrindo os braços: / Então o machacaz mechendo a bunda, / Pondo uma mão na testa, outro na ilharga, / Ou dando alguns estalidos com os dedos, / Seguindo das violas o compasso, / Lhe diz: "eu pago, eu pago"; e de repente / Sobre a michela atira o salto" (GONZAGA, 2006[1792], p.p 156-157)
} 
Inconfidência Mineira e, consequentemente, do final século XVIII, confirmando que não há somente elementos exoticamente idealizados nas gravuras; mas também uma preocupação em retratar os costumes locais, mesmo que um viés idealizado e, portanto ideológico não possa ser descartado ${ }^{63}$.

Outro aspecto é que as gravuras de Debret, Rugendas e A.P.D.G. descrevem costumes cariocas e a Carta de Gonzaga, o interior brasileiro, mais precisamente Vila Rica, hoje conhecida como Ouro Preto. Porém, outras informações mais ao nordeste, como em Pernambuco e na Bahia, por exemplo, atestam que outras regiões também praticaram o lundu, tanto em sua forma dançada quanto cantada (MOZART, 1963). Na verdade, o que entendemos é que o lundu, tanto em sua forma dançada ou como canção, constitui uma manifestação mestiça (GRUJINSKY, 2001) que foi incorporada a partir das últimas décadas do século XVIII às diversas camadas da sociedade colonial e, posteriormente imperial.

Porém, antes de continuarmos nossas discussões sobre o lundu, faz-se necessário esclarecermos que entendemos o substantivo brasileiro nessa época como uma confluência de traços culturais que atuaram durante o século XVIII, e também nos séculos anteriores, numa região geográfica dominada juridicamente por Portugal: certos gêneros culturais, como a dança e principalmente a música, vão sendo incorporados pela população deste lado do Atlântico e sendo assumidos, com ou sem modificações substanciais, como veículo da expressividade de determinadas camadas sociais vinculadas a certas regiões ou ao território brasileiro como um todo ${ }^{64}$. Nesse sentido, o relato de literatos e escritos de viajantes da época, ao descreverem os costumes da colônia brasileira, acabaram por identificar certos gêneros como sendo próprios de uma localidade específica, da metrópole ou da colônia. E isto serviu, inclusive, de distinção entre os costumes reinóis, portugueses nascidos na colônia, mestiços e escravos.

De qualquer modo, não queremos afirmar que havia no Brasil setecentista uma consciência nacional nos moldes do que ocorrerá após a primeira década do século XIX por parte da população aqui vigente; embora houvesse já uma antevisão de que o Brasil deveria permanecer uma extensão geográfica unificada e não esfacelada, e que a metrópole devia zelar para que isso ocorresse (SOUZA, 2006, p. 99). Ao contrário, concordamos que essa consciência será lenta e paulatinamente construída durante os

\footnotetext{
${ }^{63}$ Neste aspecto, concordamos com EAGLETON, T. Ideologia. São Paulo: Enesp,1997, ao defender a idéia de que numa ideologia não há somente o construção de uma discurso preocupado em instaurar um poder, mas esse discurso parte de algo real, palpável, que lhe dá sustentação.

${ }^{64}$ Não somente a iconografia, mas relatos de viajantes, já comentados acima, descrevem a presença do lundu em várias regiões como Bahia, Pernambuco. Ver: ARAUJO, M. (1963); TINHORÃO, J. R. (2004 ). Também pesquisas históricas atuais têm destacado uma convivência, mesmo que não democrática, onde há interação de elementos populares advindos das camadas sociais que conviveram nos primeiros séculos. Cf.: BURKE, 2003; SOUZA, 2006; PAIVA, 2002.
} 
primeiros séculos e amadurecida nos primeiros anos do século XIX (NOVAIS, 2005). Também o controle das administrações locais, cada vez mais reivindicado e negociado com os entes sociais da colônia será um dos maiores impulsos para um futuro Brasil desatrelado politicamente de Portugal (RUSSELL-WOOD, 2000, pp. 105-123).

Será, portanto, a partir dessas transformações mínimas que a colônia brasileira irá assumindo sua autonomia política e cultural, que de modo algum, parece se manifestar somente como ruptura, mas como diferenças sutis, verdadeiros ornamentos-monumentos $^{65}$, que se assumem como divisores de água, não mais na nomeação do mesmo, mas na identificação de um outro. E é justamente deste modo que entenderemos as discussões relacionadas com a síncope presente no lundu e que discutiremos mais abaixo.

Insistimos, de nenhum modo estamos a procura do paraíso perdido, ou seja: não buscamos os elementos primordiais que explicarão a brasilidade como um todo, pois neste caso ainda estaríamos dentro da estrutura do mito da origem e, sobretudo, dentro de uma relação puramente determinista aos moldes ainda do século XIX (ORTIZ, 2003; TRAVASSOS, 1993); tampouco estamos recolhendo características passadas e apontando o futuro, outro tempo mítico, numa espécie de controle poético/político na construção de um Brasil ideal, como o fizeram outros autores e definindo retroativamente $o$ que deve ou não ser considerado nacional ${ }^{66}$. Mas ao contrário, estamos tentando entender tanto a colônia brasileira como a futura nação brasileira como uma complexidade de forças históricas, e neste caso a cultura adentra essa lógica, que almeja certa autonomia expressiva, portanto cultural e, se possível, social, aliada ou não a uma hegemonia político-cultural, e isto, independente de uma maior ou menor consciência nacional.

Dizendo ainda de outro modo, buscamos entender o que foi a colônia brasileira num momento específico de sua história e o que alguns gêneros culturais, no caso o lundu e a modinha, significaram para os entes sociais, sobretudo, da época. Se acaso há elementos que fundaram outras tradições, ou que assumiram traços advindos de outras culturas, ou se ligam a traços ainda presentes na atualidade, isto será uma conseqüência de nossas reflexões, e não um modelo a priori em nossa conduta interpretativa.

\footnotetext{
${ }^{65}$ Uso aqui a expressão cunhada por VATTIMO, G. em La fine della modernitá. Italia: 1999, no texto Ornamento monumento, que discute o detalhe, ou aquilo que pode passar despercebido, em suam, o ornamento, como um elemento "fundante" de uma alteridade, não só por fazer parte da estrutura da obra; mas porque, a despeito de sua aparente função decorativa, orienta osso olhar, no caso, nossa escuta, para os detalhes que de modo algum podem ser desassociado à obra como um todo. $E$ sua monumentalidade estaria justificada justamente por sua presença (o ornamento) fundar uma outra obra, ou gênero. Nesse aspecto, o caráter "decorativo" deixa de estar num segundo plano para assumir seu papel de importância vital na caracterização da obra.

${ }^{66}$ Cf. capítulo 2 desta tese, texto Do romantismo à sua superação.
} 
Justamente por compreendemos a colônia brasileira como uma sociedade que propiciou certas aberturas culturais, como discutimos em capítulos anteriores, que discordamos do musicólogo Paulo Castanha ao afirmar a origem ibérica, ou espanhola, do lundu. Em seu texto Herança ibérica e africana no lundu brasileiro dos séculos XVIII e XIX (CASTANHA, 2006, pp. 21-48), apesar de o título apontar a dupla origem dessa manifestação cultural, no decorrer do texto, ao referir-se ao lundu-dança, afirma:

"Como já referimos anteriormente, o nome lundu indica existência de alguma relação entre essa dança e a cultura africana, que até o momento não foi totalmente apurada. Por outro lado os mais antigos exemplos musicais conhecidos de lundu corroboram sua possível origem ibérica" (CASTANHA, 2006, p. 30)

Os elementos espanhóis sublinhados por Castanha são: o uso de castanholas, ou das mãos dos dançarinos em posição de piparote imitando a performance deste instrumento; uma insistência na proximidade formal entre o mais antigo lundu instrumental conhecido, tal como o Lundum Brasilian Volkstanz encontrado no livro Viagem pelo Brasil (SPIX \& MRTIUS, 1981 [1821]) e o Primeiro e Segundo Lundus da Bahia, publicados no livro Cifra para Saltério (BUDAZ, 2002), e as "diferencias", ou variações, efetuadas pelos vihuelistas e guitarristas espanhóis nos século XVI e XVII; e a presença de elementos coreográficos advindos do fandango, dança de origem ibérica muito em voga nas colônias americanas.

A música para vihuela renascentista estava estruturada no contraponto imitativo modal, e em formas baseadas em baixos e/ou harmonias fixas; no caso da guitarra (e estou a imaginar a guitarra de cinco ordens), o improviso, as "diferencia", estava incorporada às mudanças na linguagem da época, ou seja, a transição do modalismo para o futuro tonalismo ${ }^{67}$. Foi nessa época que eclodiram as discussões relacionadas não somente com questões formais, mas também com questões estruturais; sobretudo, no que tange a uma nova concepção de melodia acompanhada e ao nascimento da linguagem tonal, que será de suma importância para o futuro da música não só na península ibérica, mas em toda a Europa e, inclusive, nas colônias ibéricas e portuguesas. E neste aspecto, tenhamos em conta também que o final do século XVI e a primeira metade do século XVII, mais precisamente, 1640, será o período em que Portugal cairá sob o controle de Madri, período definido politicamente

\footnotetext{
${ }^{67}$ Para um estudo mais abrangente do improviso, ver ORTIZ, Diego Tratado de glosas e clsusulas y otros gêneros de puntos em la musica de violones, Toma 1553. Alemanha: Bärenreiter, 1967. Citamos este tratado não somente por ser de compositor espanhol, mais por ter uma aceitação que extrapolou a península ibérica mesmo em sua época.
} 
como União Ibérica. Portanto, um longo período de proximidade, entre os dois reinos e que trará consequências de suma importância, inclusive, culturais.

Retornando, porém à questão colocada por Castanha, a música efetuada para vihuela, e que teve seu auge no século XVI está bastante ligada à linguagem modal, imitativa ou não, e dentro de um estilo que poderíamos classificar de renascentista ${ }^{68}$. Já a música efetuada para guitarra barroca ${ }^{69}$, participa da fundação da tonalidade, mesmo que ainda de modo bastante incipiente, e se desenvolverá dentro desse novo pressuposto: a tonalidade ${ }^{70}$. O improviso, ou diferencia, fazia parte seguramente de ambos os estilos. Além disso, muitas das peças contidas nos tratados dessa época, efetuadas para a guitarra barroca, tratam-se de músicas baseadas em formas de danças, tais como canários, folias, vilanos, além de sarabanda, passacaglia, entre outras. O improviso nessas peças não só atestava a capacidade dos músicos envolvidos na performance, mas tinham como função, às vezes, estender essas pequenas peças, algumas vezes simples arcabouços de no máximo quatro compassos.

\section{Gallarda con otros sones...}

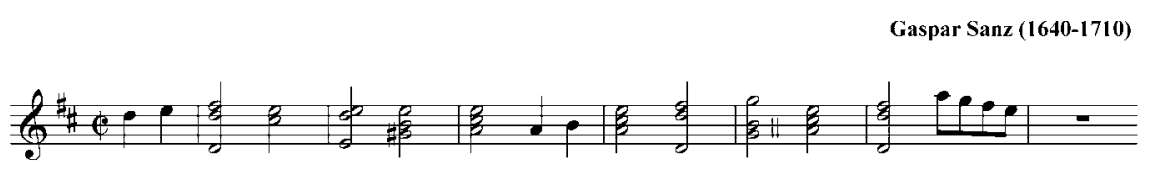

Gallarda, Instruccion de musica sobre la guitarra española, 1697.

Enfatizamos que o improviso não era uma prerrogativa de instrumentistas de cordas pinçadas, os guitarristas; era uma exigência do modelo de performance dessa época, absolutamente potencializado no que será definido posteriormente como estilo barroco, e elemento importantíssimo na elaboração do futuro bel canto. Este foi fartamente utilizado, também, por instrumentistas de tecla, como o órgão e o cravo, além de instrumentistas de arco e sopros em geral, como flautas, cornetos, entre outros. Portanto, o improviso não define um gênero determinado, mas um estilo que se aplicará a vários gêneros ao longo da história da música e, diga-se de passagem, não somente ocidental.

\footnotetext{
${ }^{68}$ Cf. MILÁN, Luis, 2000; TONAZZI, Bruno 1974.

69 É na passagem do século XVI para o XVII que a guitarra barroca adquire a quinta corda e estabiliza sua afinação como a conhecemos hoje: e, bb, gg, Dd, aa, ou e, bb, Gg, Dd, aa, ou ainda e, bb, Gg, Dd, Aa, só par citar as mais usadas, cf. TONAZZI, 1974.

${ }^{70}$ Cf. SANZ, Gaspar, Instriccion de musica sobre la guitarra española. Genebra, 1976 [1697) e MATEIS, Nicola. The false consonances of musik (1982).Great Britain: Chanterelle, 1980.
} 
Olhando de modo um pouco mais abrangente, o improviso foi praticado copiosamente por músicos não só nos séculos XVI e XVII, mas adentrou o século XVIII e persistiu no século XIX. Numa rápida folheada em livros de referência sobre a história da música ocidental, pode-se atestar que Haydn, Mozart, Beethoven, Schubert, Chopin, Liszt e Brahms, além do músico brasileiro José Mauricio Nunes Garcia, foram exímios improvisadores. Portanto, o improviso, base da futura forma tema e variação, será uma constante na música ocidental desde o século $\mathrm{XVI}$ até o XIX, adentrando o século XX; e o fato desta técnica ter permanecido, não significa que o sistema de referência (modal para tonal) não possa ter mudado; ou que não se improvisasse em gêneros e formas musicais adaptadas a cada época. Melhor dizendo, quando Mozart ou José Mauricio improvisam estão dentro de uma tradição musical que persistiu por vários séculos, mas não significa de modo algum, que estão efetuando música modal ou proto-tonal da virada do século XVI para o XVII.

Retornando à questão da vihuela e da guitarra barroca, ou guitarra espanhola como ficou conhecida posteriormente em Portugal, acreditamos que as experiências precedentes relativas a esses dois instrumentos serão seguramente a base da escola da guitarra durante o século XVII e inicio do XVIII no ocidente e, consequentemente, nas colônias ligadas a tais países. Mas acreditamos também, que essas experiências constituirão o substrato de uma forma bastante importante para a música tonal e muito difundida a partir do século XVIII denominada tema e variação (STEINS,1979, p. 95). Portanto, não acreditamos que seja necessário retornar ao modalismo do século XVI para explicarmos o lundu da segunda metade do século XVIII, sobretudo porque o gênero tema-variação nessa época, já está absolutamente ligado ao estilo e à forma clássica, completamente enraizada na música da segunda metade do século XVIII.

O que percebemos é que lundus, instrumentais e cantados, analisados por Castanha, se comportam de modo diverso da música de fins do renascimento e início do barroco. O Lundum, Brasilian Volkstanz, um dos lundus mais analisados da história desse gênero, inicia com uma frase de cinco compassos em anacruse de colcheia, e se comporta como um longo improviso alternando harmonicamente a tônica e a dominante de dois em dois compassos dentro de uma estrutura formal fraseológica clássica: frases de quatro compassos formadas por semi-frases de dois, com padrões quase sempre repetidos. O estilo das semi-frases com colcheias pontuadas e às vezes duplamente pontuadas, também nos lembra motivos clássicos. No final da peça, e à guisa de coda, há uma frase de seis compassos (cc.98-103). Outro fator não menos importante é a insistência nos arpejos, quando não se desenvolvem motivos melódicos, bastante dentro da tradição rococó-clássica; e não 
do estilo barroco com baixos fixos sobre os quais se formam acordes. Sobretudo nos compassos 80 a 83 , o uso de acciacaturas, e também a presença sutil de staccatti, entre os compassos 25 e 40, bem ao gosto das articulações do século XVIII. Portanto, esta peça constitui sim um longo improviso, mas ao gosto do século XVIII e, como afirmado acima, dentro de um estilo galante-clássico.

Apix.

$$
\text { Tandum, Prasilian. Sothstanx. (") }
$$
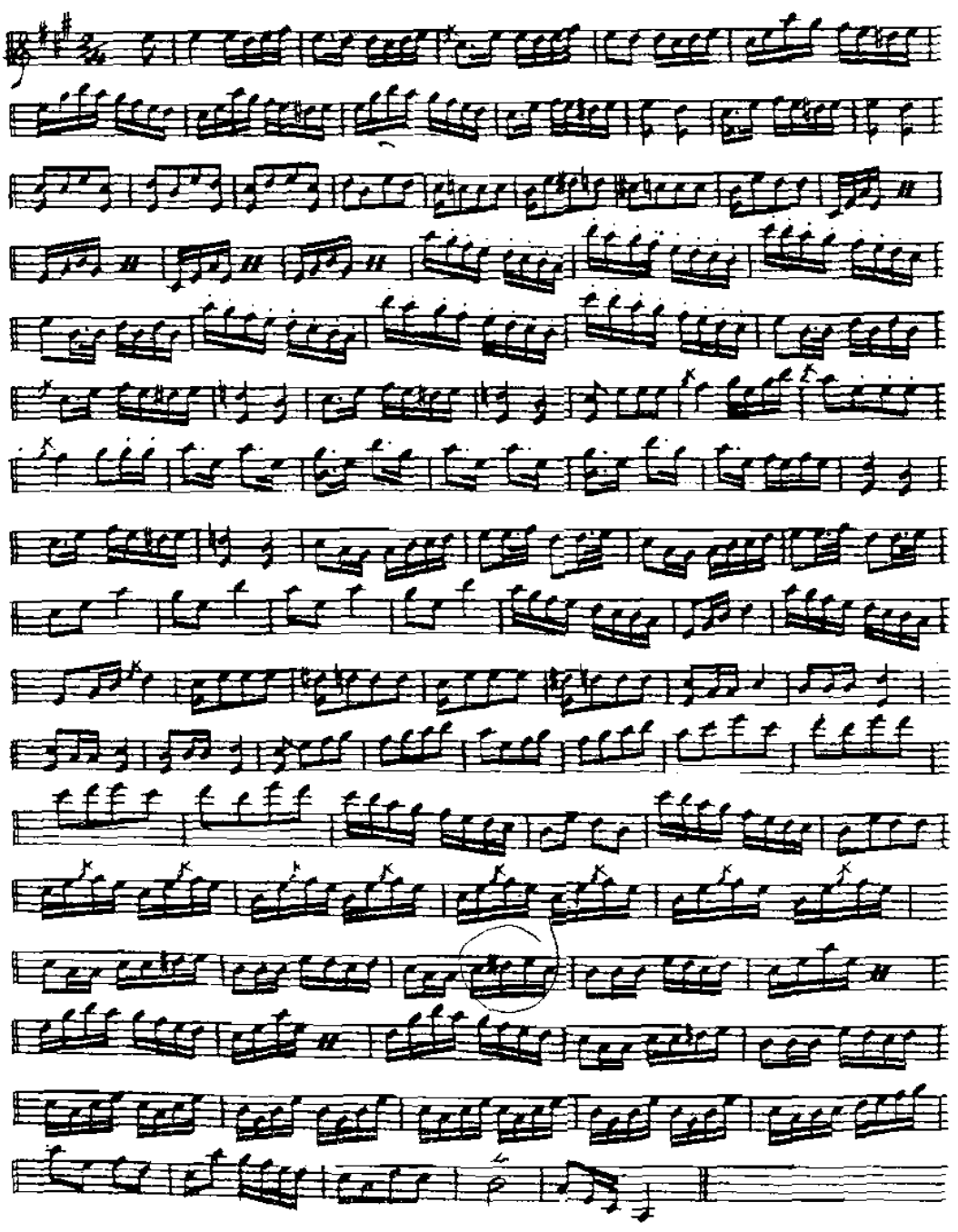

1 Dança popular hrasileira. 
O Primeiro Lundus da Bahia, extraído do livro de Budasz (2002), alterna uma estrutura fraseológica de dois em dois compassos, também insistindo nos acordes de tônica e dominante. Estes, por sua vez, são arpejos alternados de dois em dois compassos onde, em alguns momentos, figuram pequenos trechos de melodia, á guisa de improvisos, esboçando sutilmente síncopes melódicas que serão características nos futuros lundus cantados da virada do século e dos instrumentais do século XIX. Mas a estrutura geral da peça e sua opção fraseológica estão totalmente de acordo com o lundu comentado anteriormente.

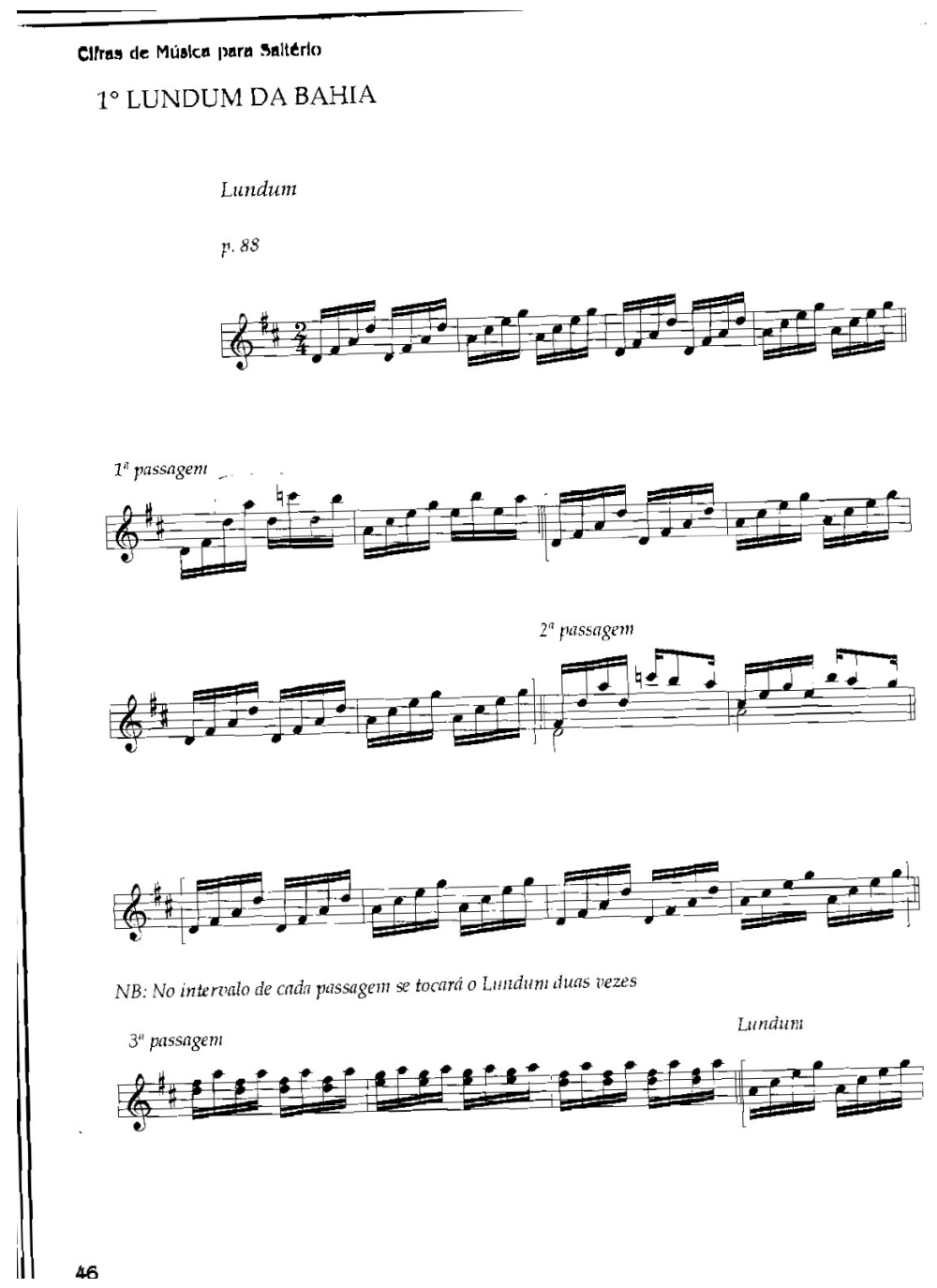

Primeiro Lundum da Bahia (trecho), Cifras de Música para Saltério (BUDASZ, 2002) 
Outro fator que parece distanciar o lundu, pelo menos em sua parte musical, de uma origem somente ibérica/espanhola é a ausência de emíolas, ou seja, a alternância entre métrica ternária e ajustes binários presentes na música espanhola, sobretudo por esta ocorrer em peças musicais em métrica ternária ou em métrica composta onde divisões internas deslocam os tempos contrariando os acentos convencionais da métrica ternária simples ou composta ${ }^{71}$.

Canto

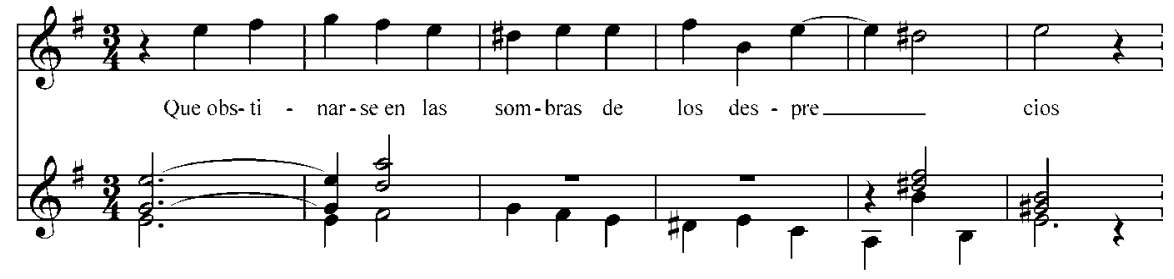

Desengañemonos ya, José Marín (1619-1699)

Outro aspecto muito recorrente na música de origem espanhola é a presença de cadências frigias, ou seja, sequência de acordes em tonalidade menor que partem da tônica em direção á dominante, também conhecida como semi-cadência (KOSTKA, 2004,p. 150). Abaixo, apresentamos um exemplo extraído do Concerto Grosso “La follia" de Francesco Geminiani (1680-1762), que embora seja um compositor italiano, ao compor um gênero eminentemente espanhol, conserva a cadência frigia, típica desse estilo:

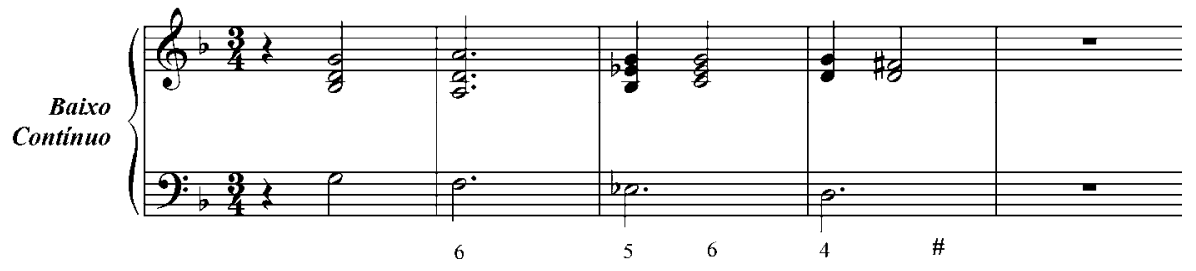

La follia de Francesco Geminiani (1680-1762)

\footnotetext{
${ }^{71}$ Merece ser destacado que o fandango, gênero que participa da composição do lundu-dança, trata-se de uma dança em métrica ternária e os lundus analisados por Castanha, estão em métrica binária. Até o presente momento, lundus com métrica binária composta, como Dizem que sou borboleta, pertencente ao arquivo musical Curt Lange do Museu da Inconfidência (Outro Preto, MG), são raros. Com base neste exemplo, poderíamos aproximar a peça Uma mulata bonita (SPIX \& MARSIU: Viagem pelo Brasil. Belo Horizonte: Itatiaia, 1981[1820], p. 300), também em métrica binário composto. A hipótese que aventamos é de que se fossem efetuadas síncopes na interpretação dessas peças que não constam nos documentos, elas se ajustariam bem a uma performance em compasso binário simples! Portanto, dentro dos lundus tradicionais. - talvez essa discussão deva abranger o lundu no século XIX
} 
Mesmo os lundus em tonalidades menores, como Os me deixas que tu dás, do códice Modinhas do Brasil, do final do século XVIII (LIMA, 201, pp. 81-84), o lundu Menina você que tem de J. F. Leal (LEAL, 1830), este da primeira metade do século XIX, não apresentam essas características: nem a emíola melódica e nem a sequência harmônica frigia. Pelo contrário, preferem polarizar a dominante pela sua dominante individual ou chegar à tônica através da dominante precedida da subdominante, com ou sem inversão, como ocorrerá com vários outros lundus tanto do século XVIII como do primeiro quartel do século $\mathrm{XIX}^{72}$.

\section{Os me deixas que tu das...}
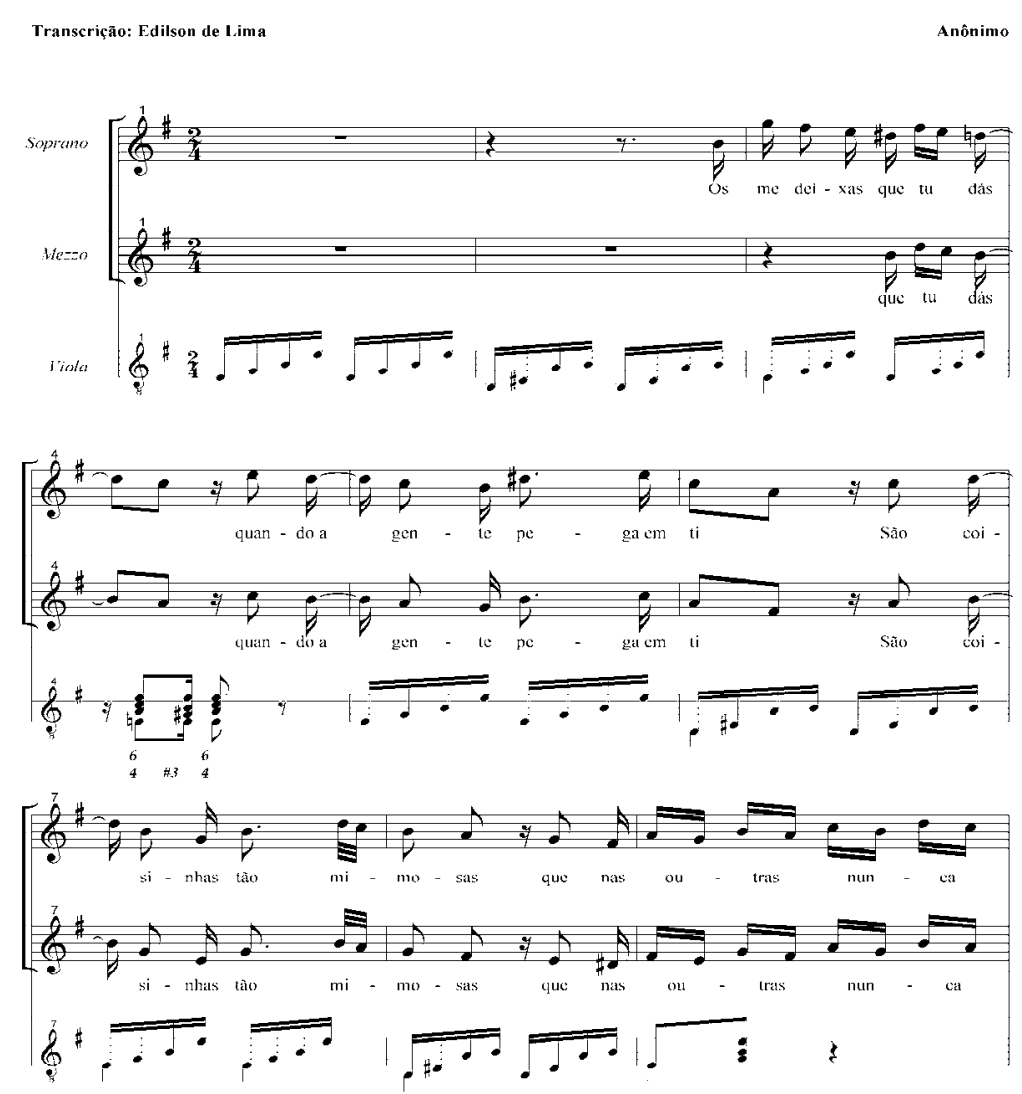

C) 1999 by tdilsen de lima $\quad 12$

\footnotetext{
${ }^{72}$ Para mais exemplos musicais, ver os lundus: Eu venho achar os pezares (MORAIS , 2003: 140-2), Esta noite, ó céus que dita (www.bn.br/manuscritos/musica. LEAL, J. F. 1827.
} 

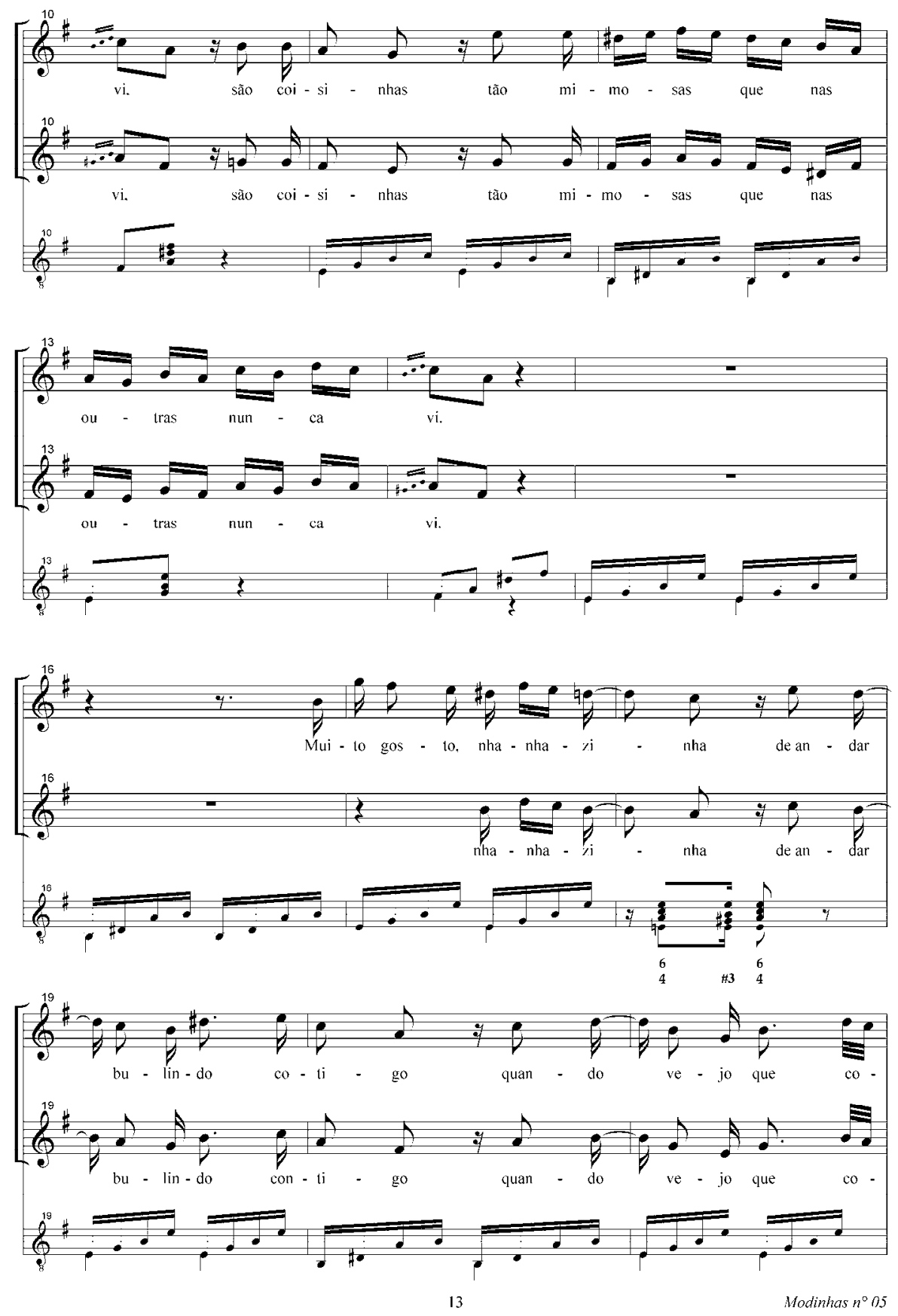

Os me deixas que tu dás, Modinhas do Brasil (LIMA, 2001) 


\section{Menina você que tem}

guitarra: edilson de lima

J.F. Leal
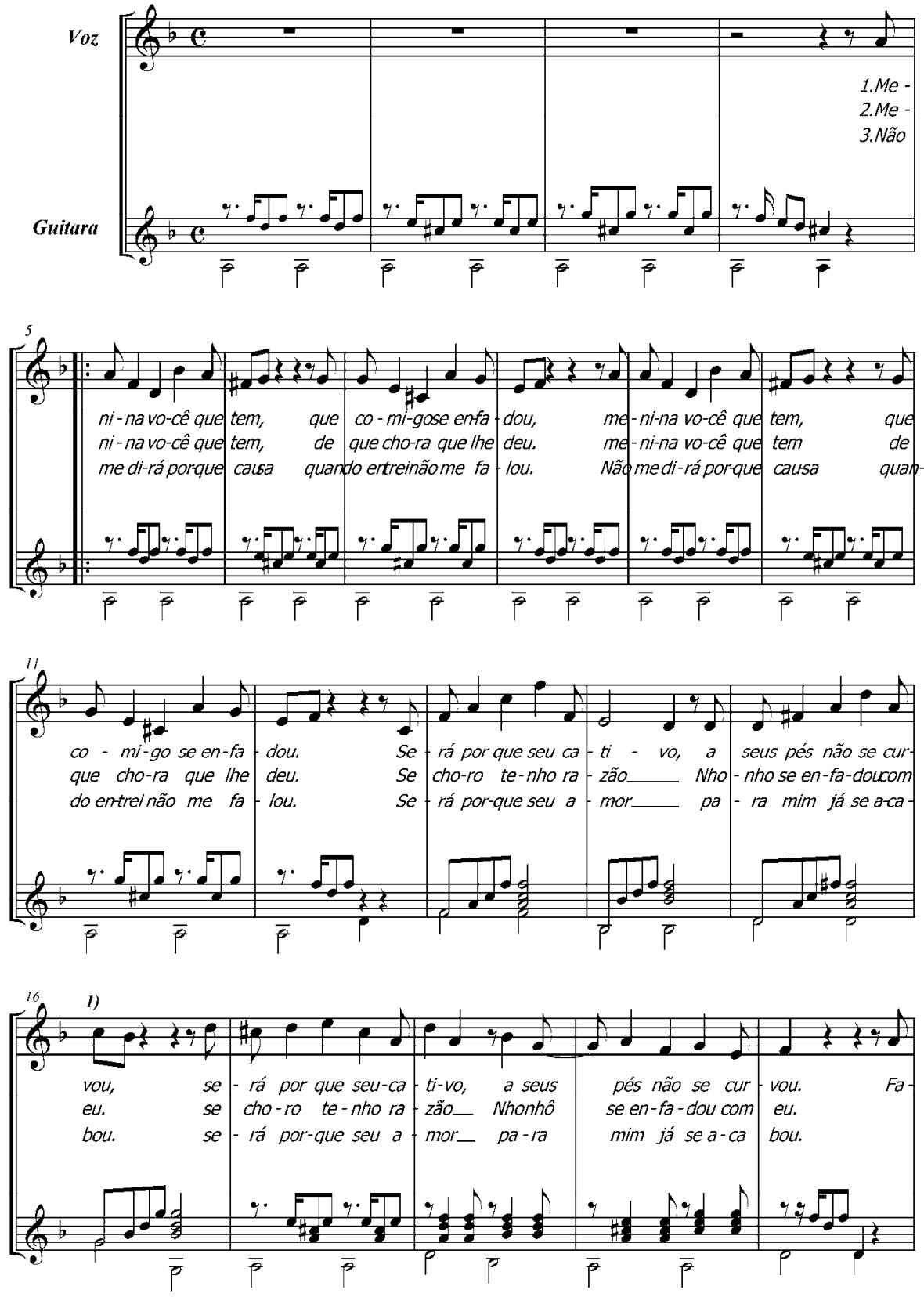
2
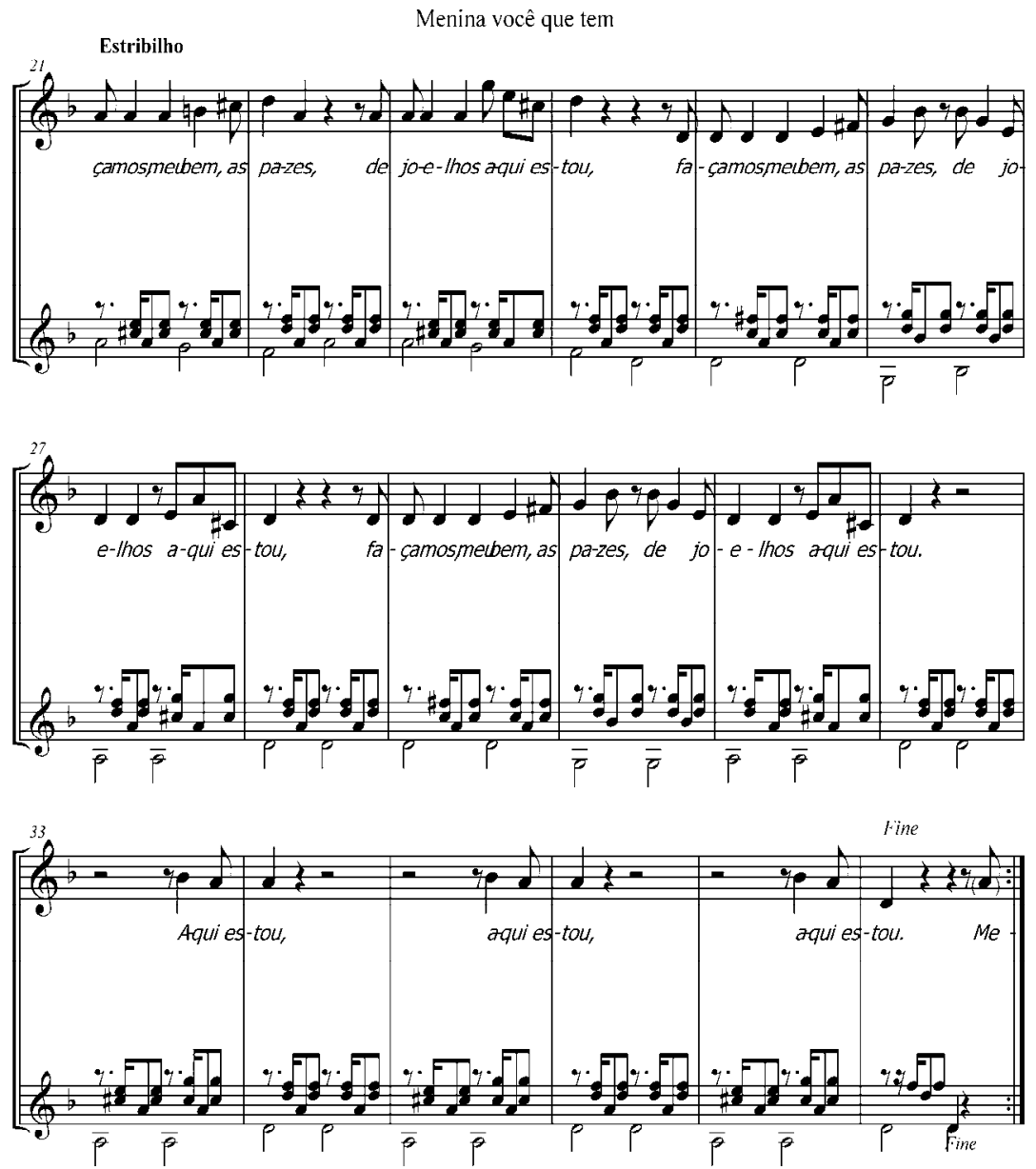

2. Menina você que tem,

De que chora, que lhe deu.

Se choro tenho razão

Nhonhô se enfadou com eu.

Façamos, meu bem, as pazes,

De joelhos aqui estou.

3. Não me dirá por que causa

Quando entrei não me falou,

Será porque seu amor

para mim já se acabou

Façamos, meu bem, as pazes,

De joelhos aqui estou.

Menina, você que tem, J.F. Leal

Nos lundus analisados por Castanha, além da preponderância da tonalidade

maior, dificultando a elaboração de cadências frigias à moda espanhola $\left(\mathrm{Dm}^{(6)}, \mathrm{C}, \mathrm{Bb} \mathrm{e}\right.$ 
A!, por exemplo); também a opção pela métrica binária, característica do lundu, de modo algum permitem as emíolas á moda ibérica ou espanhola, considerando estes deslocamentos como usados tradicionalmente ${ }^{73}$. Portanto, mesmo concordando com a tradição do improviso que se mantém na música ocidental, o lundu, nem mesmo os analisados por Castanha, apresentam em suas escritas musicais características que nos remeteriam a traços espanhóis, tais como a presença da tradicional emíola e das cadências frigias tão comuns em tonalidades menores como discutido acima. Muito pelo contrário, mais tarde haverá uma tendência pelas melodias sincopadas, ou seja, deslocadas em relação ao acento métrico musical convencional, tanto nos lundus cantados quanto nos lundus instrumentais, mas com outras características que não aquelas espanholas.

Ao aproximar a fraseologia desses lundus à fraseologia das peças de guitarra dos séculos XVI e XVII, Castanha efetua uma associação bastante simples e direta atendo-se somente ao improviso e à estrutura tema e variação (a diferencia), como caracterizador de um gênero que nasce da associação de elementos complexos, mas já dentro de um estilo absolutamente clássico. E, além disso, ao estudarmos tratados dessa época que sistematizaram o aprendizado da viola de arame e da guitarra inglesa em Portugal, como a Nova arte de viola de Paixão Ribeiro (1789) e o Estudo de Guitarra de Antonio da Silva Leite (1796), vemos que ao final, na tradicional coletânea de peças indicadas aos leitores como exemplos e exercícios, não constam mais as peças que serviram de modelos para tratados do início do século XVII, tais como jacaras, passacalles, españoletas, fólicas, canários, entre outras (SANZ, $1967)^{74}$. Mas os gêneros que servem de exemplos musicais nos métodos portugueses do último quartel do século XVIII são o minueto, a contradança, a modinha (Paixão Ribeiro), a marcha, a fantasia, a fanfarra, a gavota (Silva Leite), dentro de um estilo preponderantemente clássico. ${ }^{75}$ Ou seja, estas peças estão construídas dentro de pressupostos formais clássicos: frases articuladas e periódicas, formas simétricas. Por exemplo:

\footnotetext{
${ }^{73}$ A emíola será uma técnica bastante utilizada no renascimento e primeiro barroco e não somente na música espanhola. Vamos encontrar essa prática nas chansons francesas, na frottla e villanela da tradição renascentista italiana, nas canções de Orlando de Lassus, entre outros. O que defendemos é que a emíola, completamente enraizada na música ibérica, constitui-se em um resquício da tradição da notação do ritmo modal advindo da Idade Média que será mantido na tradição ocidental se enraizando com maior ou menor ênfase em alguns povos.

${ }^{74}$ Optamos pelo método Instruccion de musica sobre la guitarra española. Genève: Minkof, 1976 por este ter sido um dos tratados de guitarra espanhola mais difundidos na Península lbérica.

${ }^{75} \mathrm{O}$ estilo e forma das peças contidas nesses métodos apresentam as mesmas características do estilo clássico discutido nos capítulos precedentes, como frases articuladas e periódicas, organizadas em formas simétricas, sejam estas binárias ou ternárias.
} 


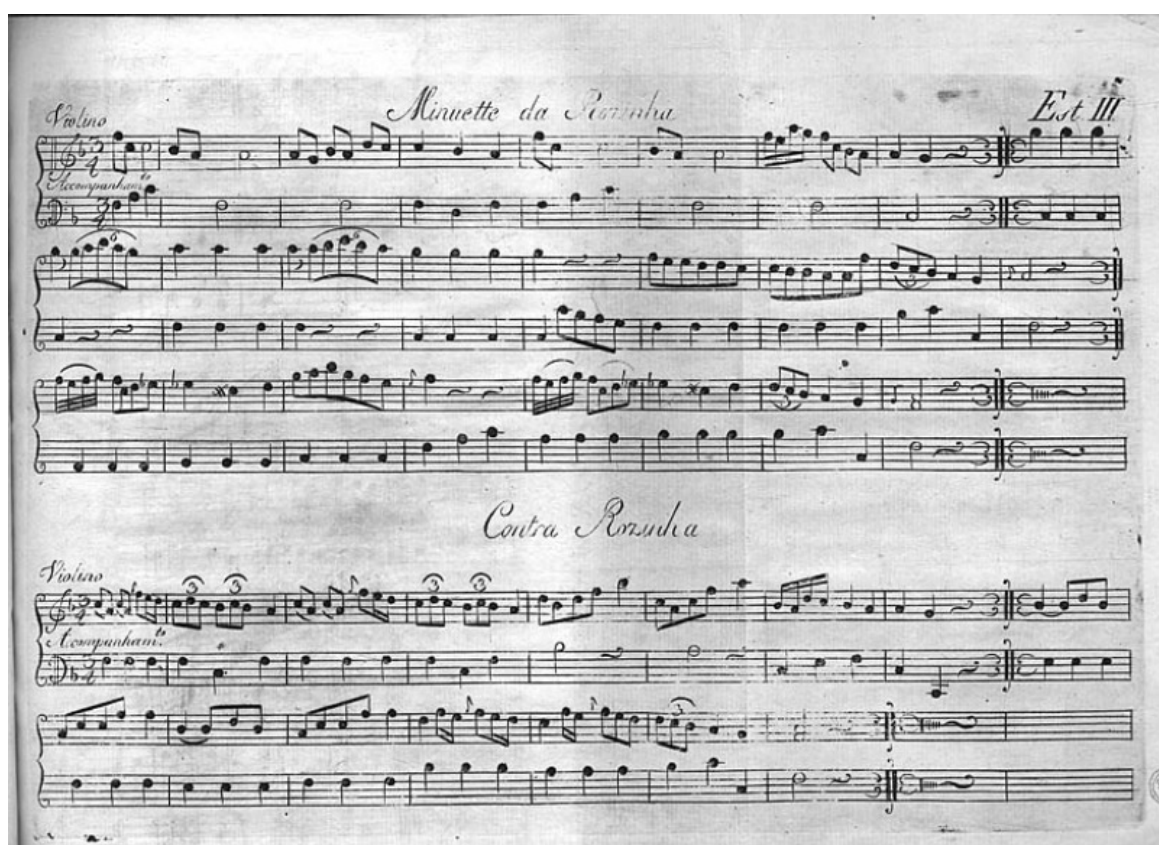

Exemplo musical extraído da Nova arte de viola de Paixão Ribeiro (1789)

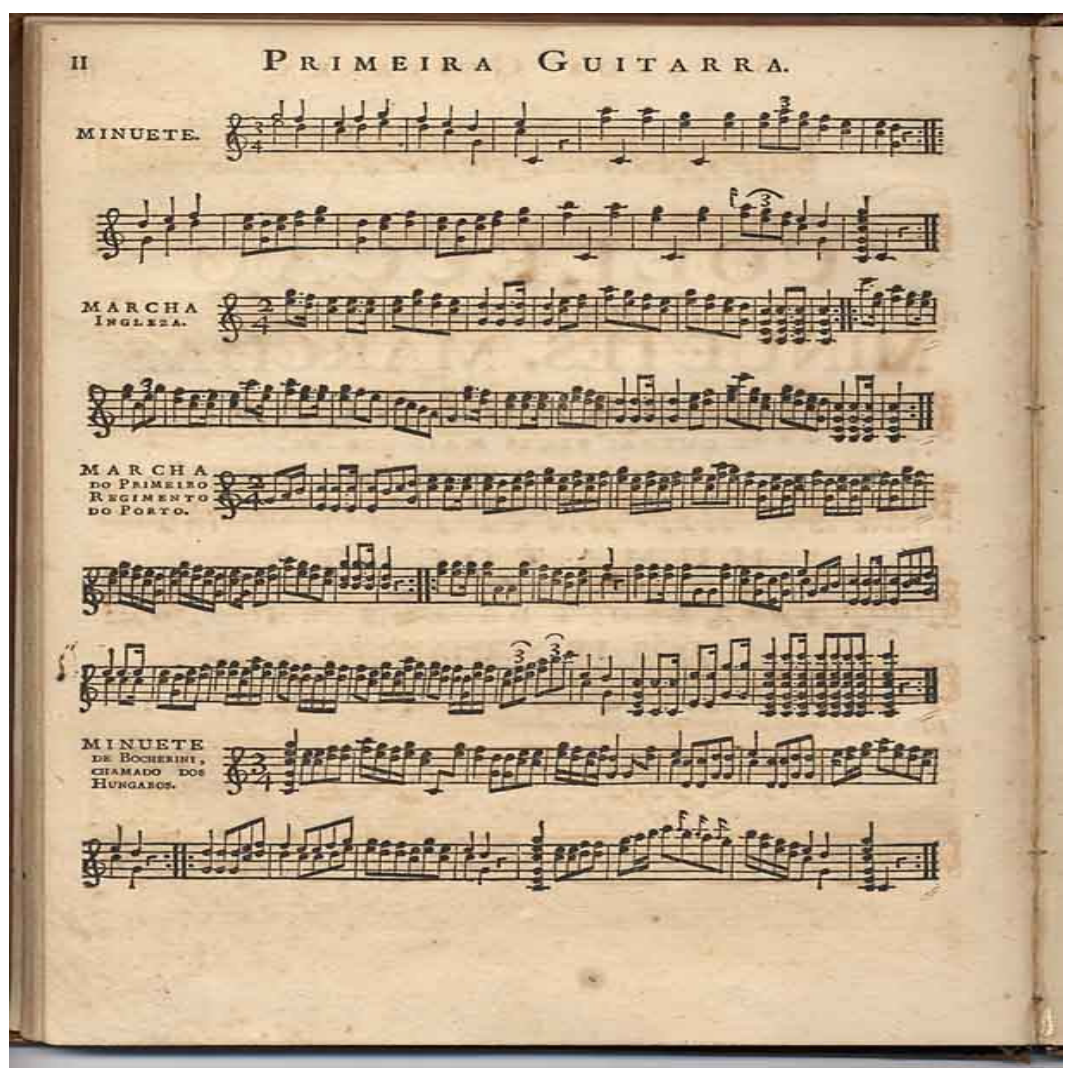

Exemplo musical extraído do Estudo de Guitarra de Antonio da Silva Leite (1796) 
Em outro trecho de seu texto, Castanha aplica essa mesma lógica de análise a dois lundus, estes já em sua forma cantada, do final do século XVIII, Eu nasci sem coração de compositor anônimo e Já se quebraram os laços de José de Mesquita e afirma:

"Embora não possam ser caracterizadas como variações, tais células exibem, entre si, contrastes na configuração, ao mesmo tempo que procuram repetir certos padrões melódicos (...) tal como referido no lundu instrumental" (CASTANH, 2006,. p. 40).

Em nosso entender o lundu, tanto em sua forma dançada quanto cantada, está absolutamente ligado à complexidade cultural vigente na segunda metade do século $\mathrm{XVIII}$, tanto presente no continente americano, quanto na corte e, sobretudo em Lisboa, mesmo que de um modo menos enfático. Como um gênero cultural, seja na forma de dança, seja na forma de canção, participa na construção da sociedade da época: ou seja, se a música praticada no lundu dança se emancipa no gênero canção, esta já encontra na modinha aspectos formalisticamente estabelecidos, um porto seguro; ou se o lundu trás em seu arcabouço tendências próprias, é o que pretendemos discutir abaixo. Porém, se na colônia brasileira, aproximações entre camadas populares e elite foram mais toleradas e na metrópole foram menos consentidas, isso não invalida as trocas culturais, mas as acentua ou minimiza. E é nesse sentido que entendemos ambas as formas de expressão do lundu no século XVIII, a dançada e a cantada, e sua relação com a expressividade da época: e será destas aproximações e distanciamentos que o lundu poderá se associar à modinha e contribuir com algumas características que consideramos próprias.

Tanto o lundu Eu nasci sem coração do códice Modinhas do Brasil (LIMA, 2001, p.87-88), quanto o Já se quebraram os laços publicado no Jornal de Modinhas (ALBUQUERQUE, 1996, pp. 52-53) de autoria de José de Mesquita, ambos, diga-se de passagem, anteriores ao alvorecer do século XIX, comportam-se como genuínas formas tão comuns no século XVIII e absolutamente incorporados ao estilo galanteclássico. O primeiro lundu, Eu nasci sem coração, apesar dos arpejos introdutórios da viola de arame, tem a primeira parte construída por duas frases, a primeira de quatro compassos (3-7), e a segunda contendo seis compassos (9-15), comportando-se como uma variação ornamentada da primeira, com uma extensão dos dois últimos compassos da frase (STEIN, 1979, p. 31-34). A segunda parte desse lundu comportase como uma única frase de nove compassos, formada por dois motivos: um que se repete três vezes (cc. 17-22), outro que finaliza a peça dirigindo a melodia para a tônica (cc. 23-25 - LIMA, 2001). O que merece ser frisado, é que essa peça possui uma forma assimétrica, dentro dos pressupostos ainda do estilo galante (GROUT, 
2006, p. 480). Porém, seu fraseado não se comporta com um improviso livre, mas dentro dos pressupostos formalísticos já completamente absorvidos pela música setecentista, buscando, sobretudo a repetição da frase, ou a periodicidade, além disso, os arpejos repenicados da guitarra ou viola potencializam, à guisa de Baixo de Alberti, o gosto galante.

\section{Eu nasci sem coração}

$$
-06-
$$
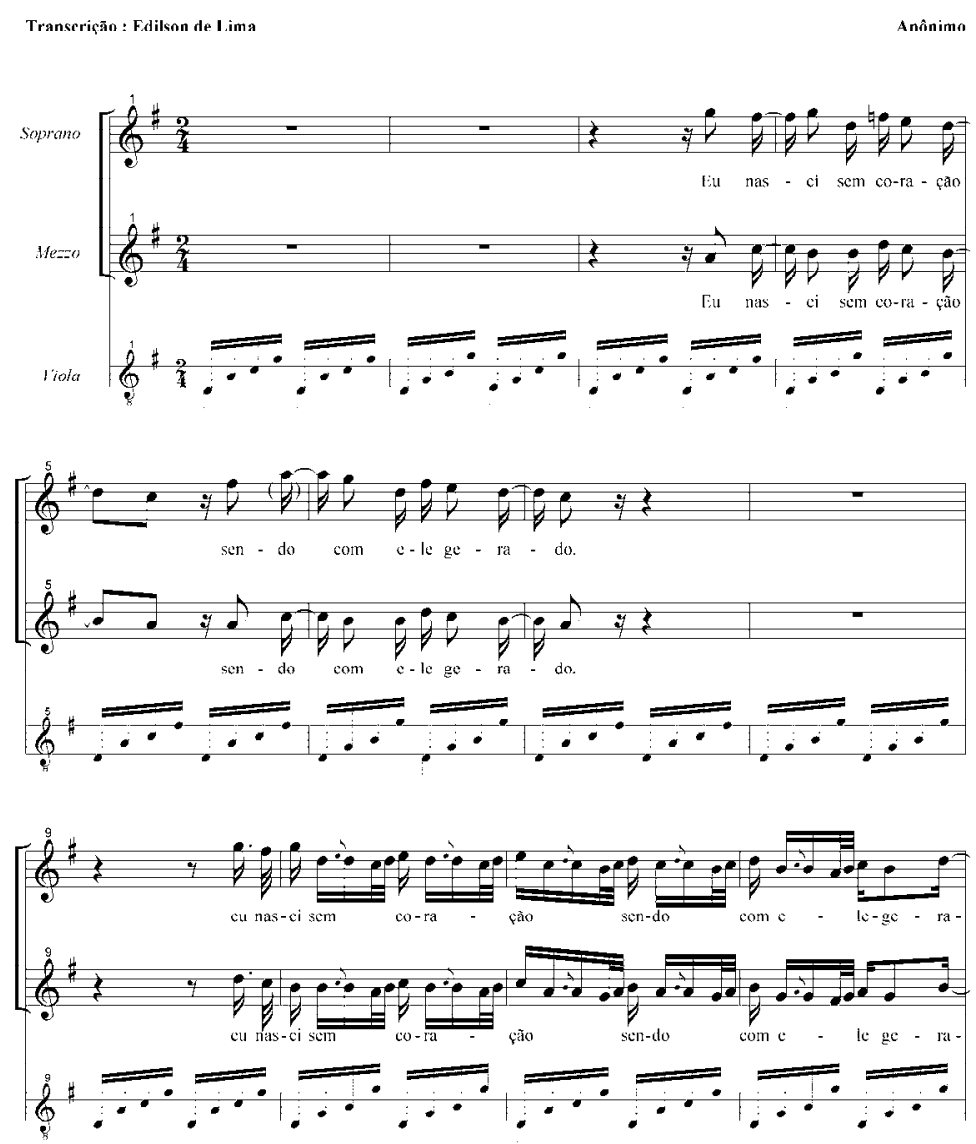

o 1999 by Fidilson de Lima 

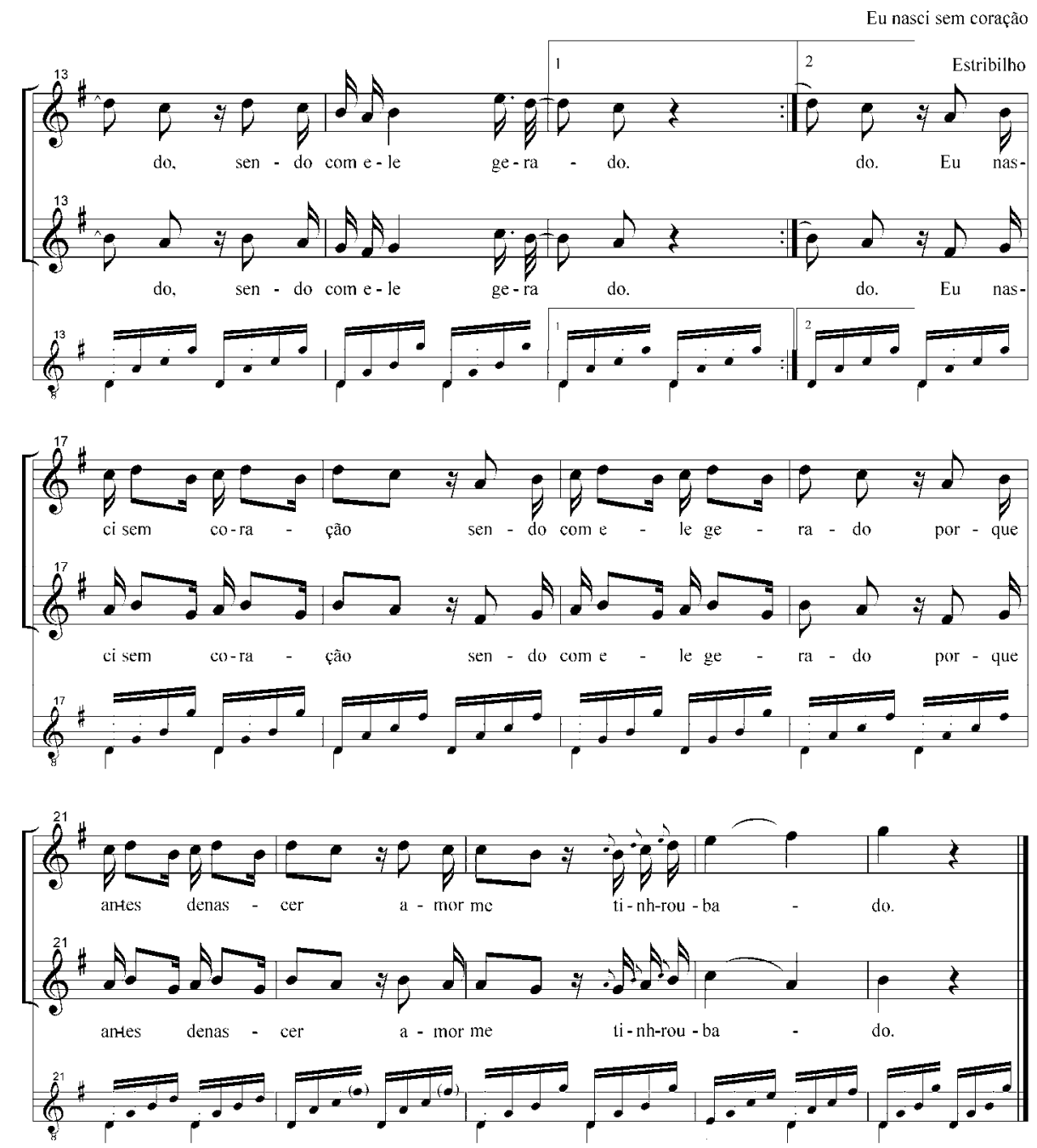

Eu nasci sem coração, Modinhas de Brasil (2001)

Ainda refletindo tendências galantes, ou seja, um formalismo ainda assimétrico, mas já dentro de pressupostos, a nosso ver, clássicos, o lundu Eu estando bem juntinho (LIMA, 2001, pp. 149-150) está construído em duas seções, onde a parte A possui 8 compassos (cc. 5-12); e a segunda parte, formada apenas por uma frase, se considerada anacrústica, possuiria 4 compassos (cc. 13-17); se considerada acéfala, possuiria 5 compassos. Entre os compassos 18 a 21, o autor retoma a primeira semifrase da primeira parte, rearticulando sua frase conseqüente e a direcionando para a tônica, um A', portanto, construindo uma genuína forma ternária, mesmo que levemente assimérica. Os acordes arejados em alternância com acordes "plaquês" sobre baixos fixos, contribuem ainda mais para o estilo clássico deste lundu. 


\section{Eu estando bem juntinho}

$$
-18-
$$

Transcrição: Edilson Vicente de Lima

Anônimo
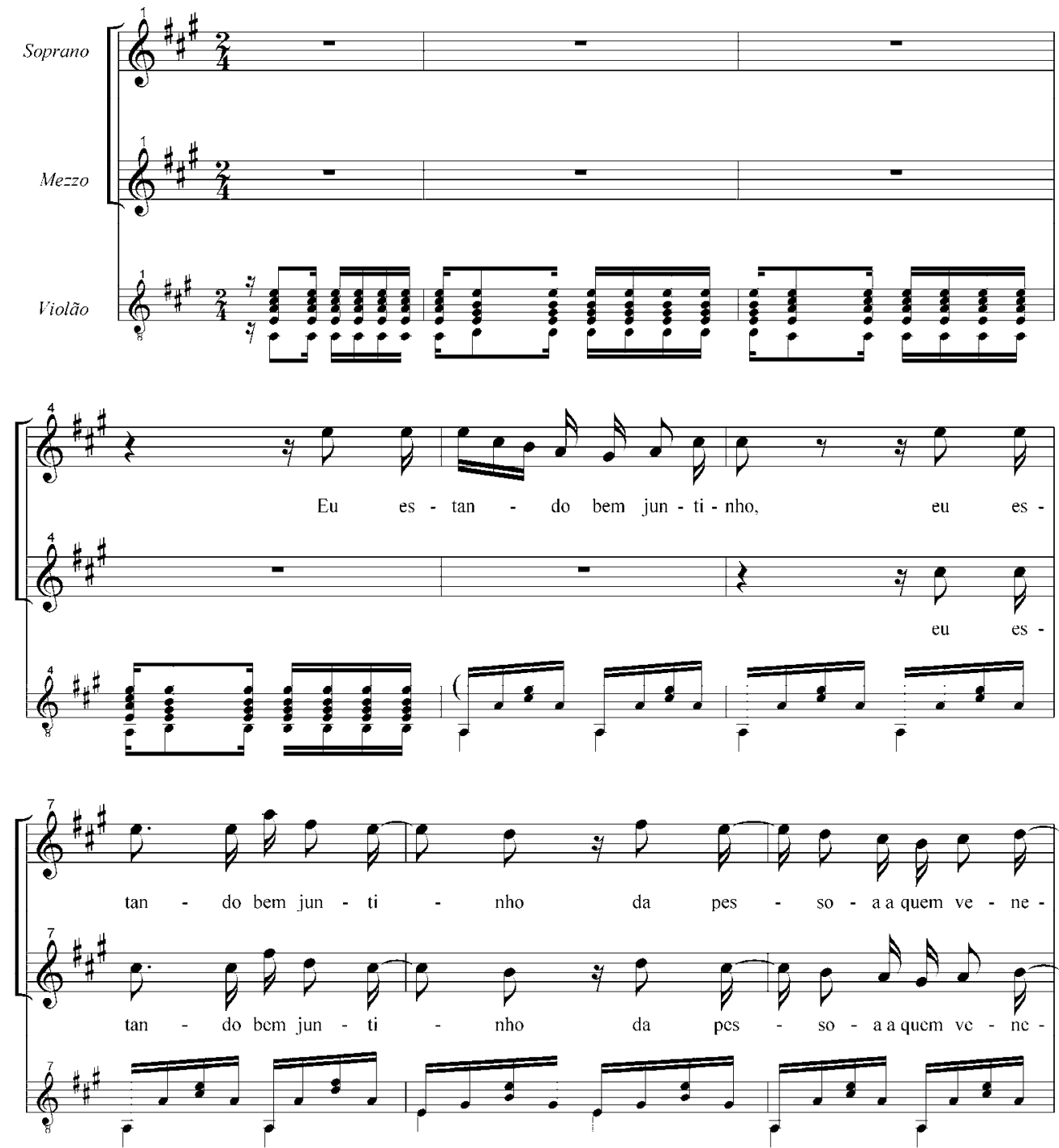

(C) 1999 by Edilson de Lima 

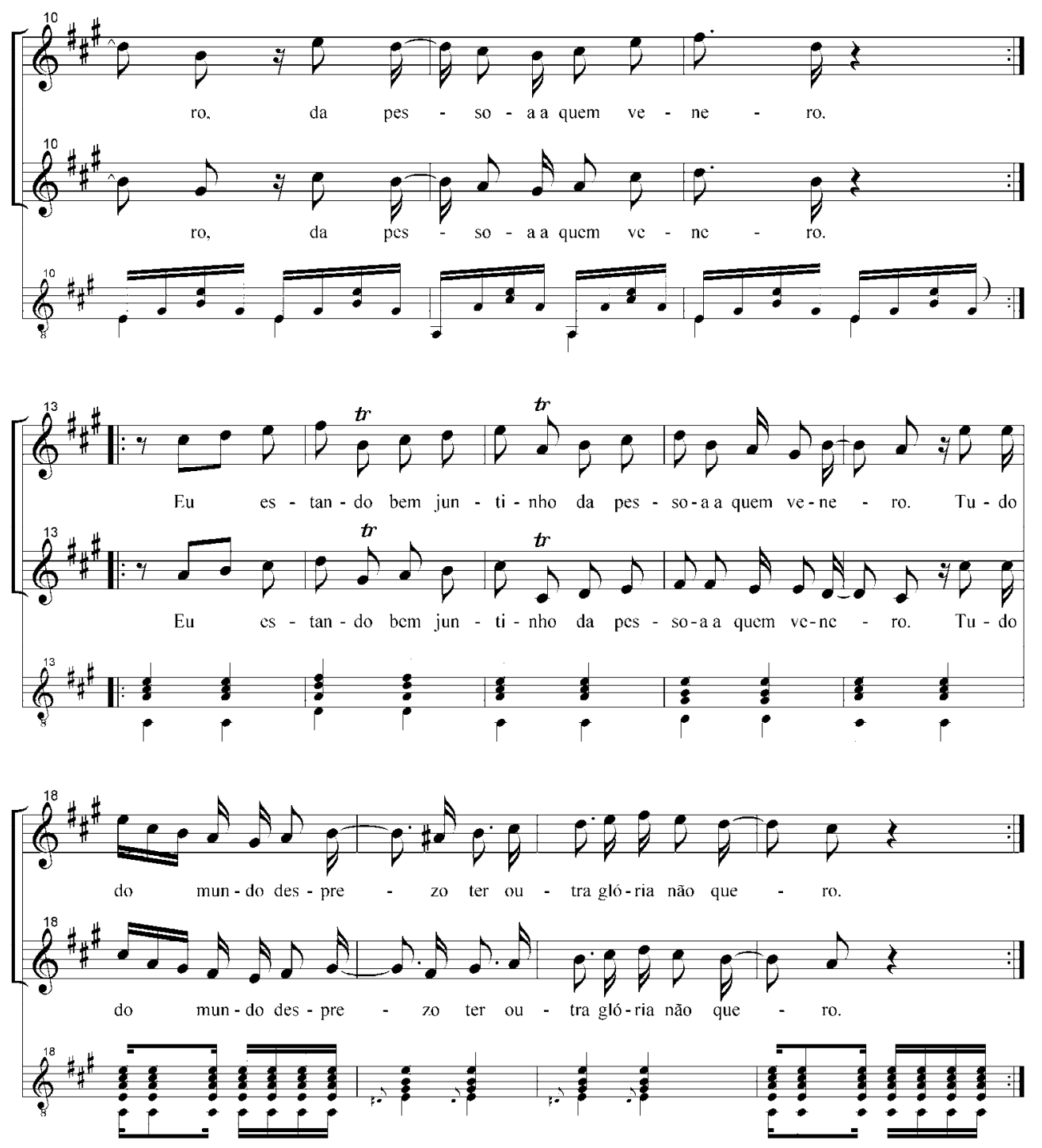

Eu estando bem juntinho, Modinhas do Brasil (2001)

Outros lundus, e também modinhas evidentemente, pertencentes ao mesmo códice se encaixam dentro desses esquemas formais, tais como Ganinha, minha ganinha (LIMA, 2001, p. 91-2). Esse lundu está estruturado num esquema formal $A B A^{\prime}$, onde $A$ é formado por uma frase de oito compassos iniciada em anacruse; o $B$, também contendo oito compassos, porém formado por uma frase de quatro repetida, sendo a segunda uma variação da primeira; a terceira parte do lundu, o A' com oito compassos, sendo uma variação, da seção $A$ inicial e finalizando suspensivamente, 
quebrando o esquema lógico antecedente-consequente da estruturação clássica ${ }^{76}$, em uma forma absolutamente simétrica. Junte-se a essa questão, seu acompanhamento em acordes arpejados, tão comuns em peças setecentistas, mas ausentes em peças barrocas e renascentistas.

\section{Ganinha, minha ganinha}

$$
-07-
$$

Trasncrição: Edilson de Lima
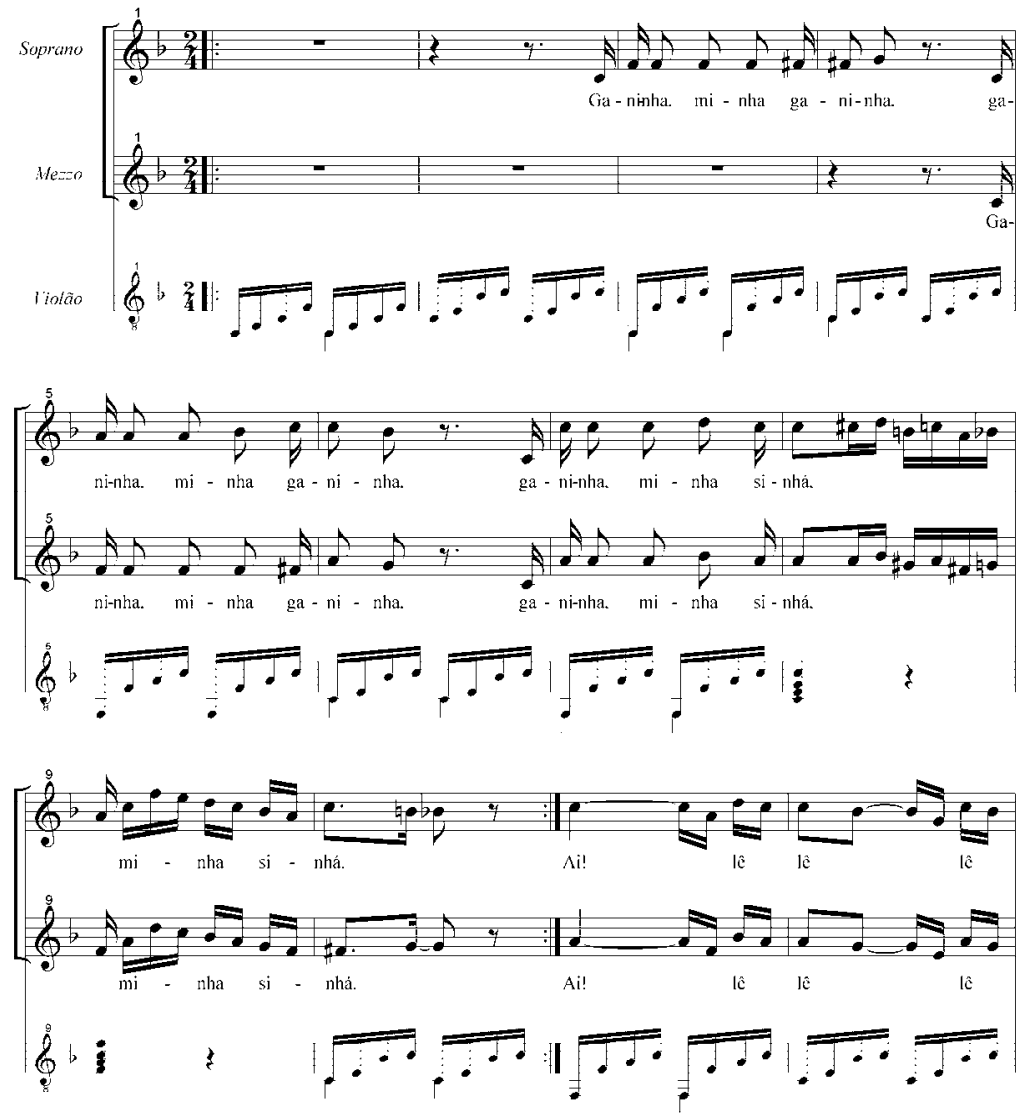

(c 1999 by Edilson de Lima

18

\footnotetext{
${ }^{76} \mathrm{Na}$ frase clássica formada por duas semi-frases, geralmente sua primeira metade, denominada antecedente, finaliza suspensivamente (geralmente na dominante da tonalidade em questão); e sua segunda metade, que caminha para uma conclusão, finaliza na tônica (KOSTIKA, 2004)
} 

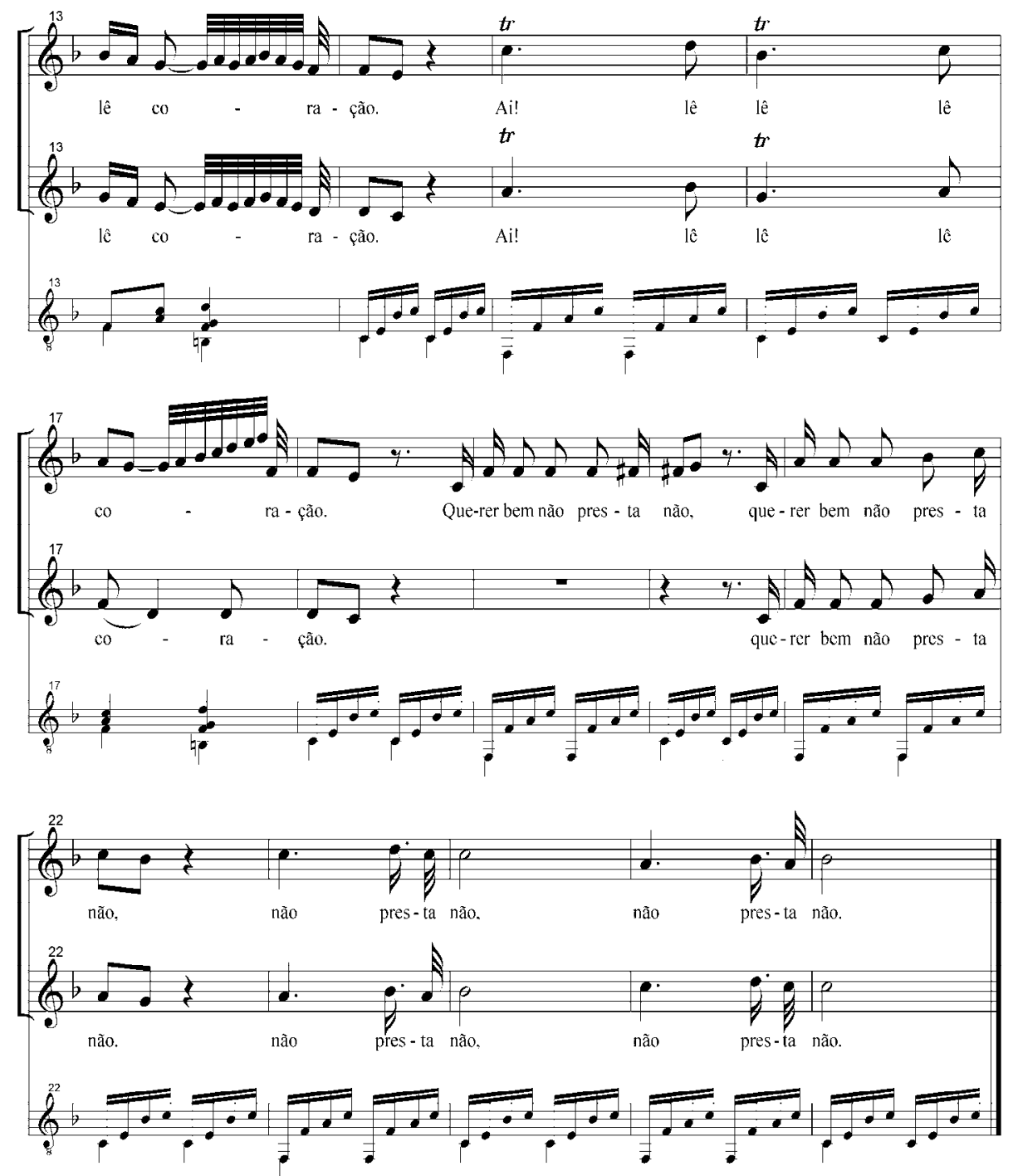

Ganinha, minha ganinha, As modinhas do Brasil (LIMA, 2001)

O lundu Já se quebraram os laços, o outro lundu comentado por Castanha, pode ser dividido analiticamente em três seções, em uma forma ternária, ABA': a primeira seção, o A (cc. 5-16) é iniciada com uma pequena introdução de quatro compassos a cargo do teclado efetuando um Baixo de Alberti alternando tônica e dominante na mão esquerda, enquanto a mão direita efetua um motivo sincopado iniciado por pausa que será reutilizado durante a peça e retomado nos compassos 18 a 20, como elemento que divide a primeira da segunda seção e na finalização da peça. A segunda seção (cc.21-28) possui oito compassos formados por duas frases de quatro compassos cada. A seção terceira, o A' (cc. 29-44) possui dezesseis compassos, é iniciada com a terceira frase da parte A seguida por uma nova frase, 
iniciada, no entanto, com o mesmo material motívico da segunda frase da primeira seção na terça do acorde de tônica, a nota lá. Nos compassos 37-44, o autor efetua a repetição, mas conduzindo o final para a nota fá. Portanto, não somente no esquema formal, mas toda a opção fraseológica se encaixa dentro de uma busca classicizante: formalismo global da peça, frases articuladas e periódicas e baixo de Alberti. A peça finaliza com o mesmo material temático da introdução e interlúdio que tem caráter, frisemos, absolutamente coreográfico, acusando seu parentesco com os lundus dançado, além do motivo em síncope.

\section{Já se quebraram os laços}
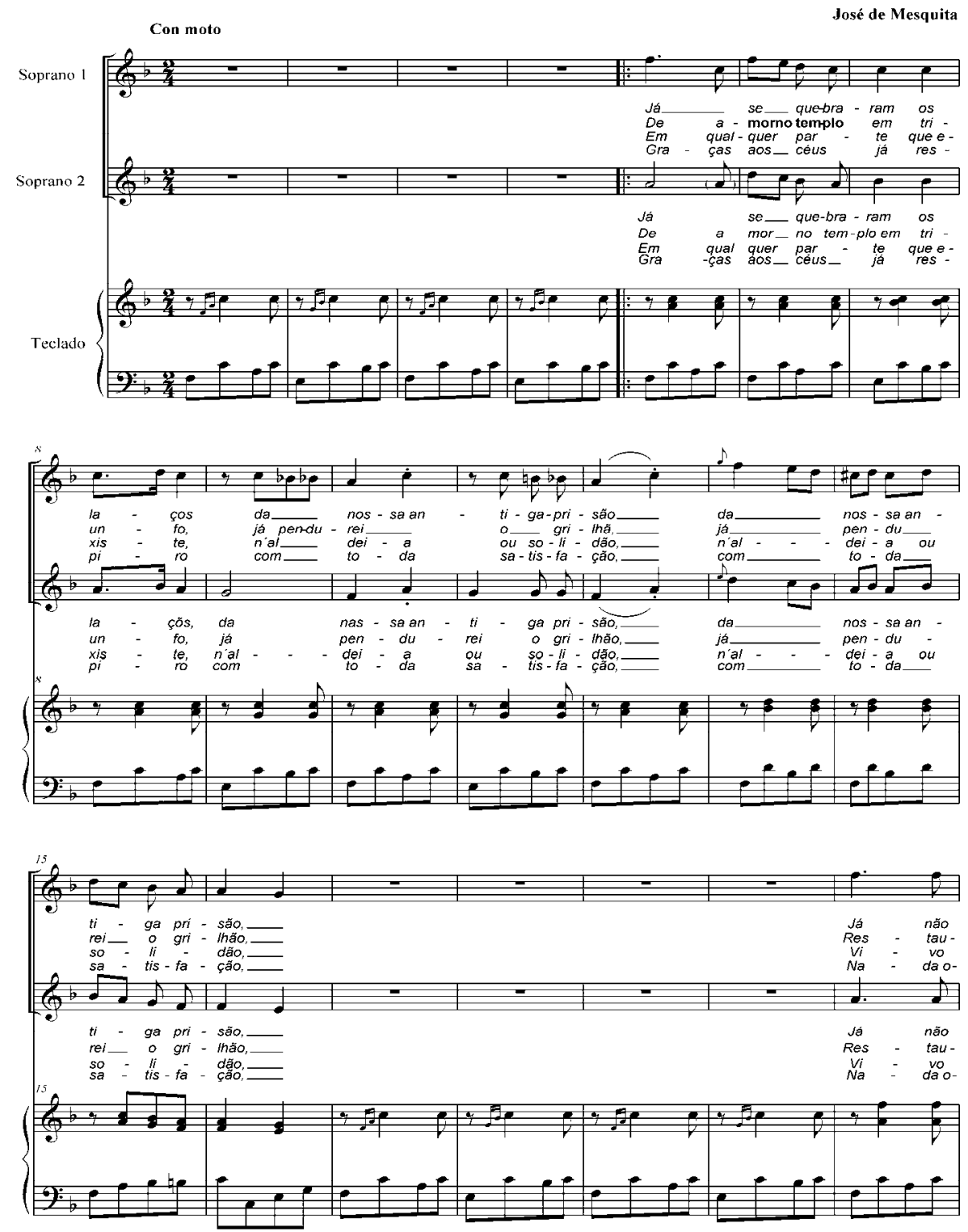

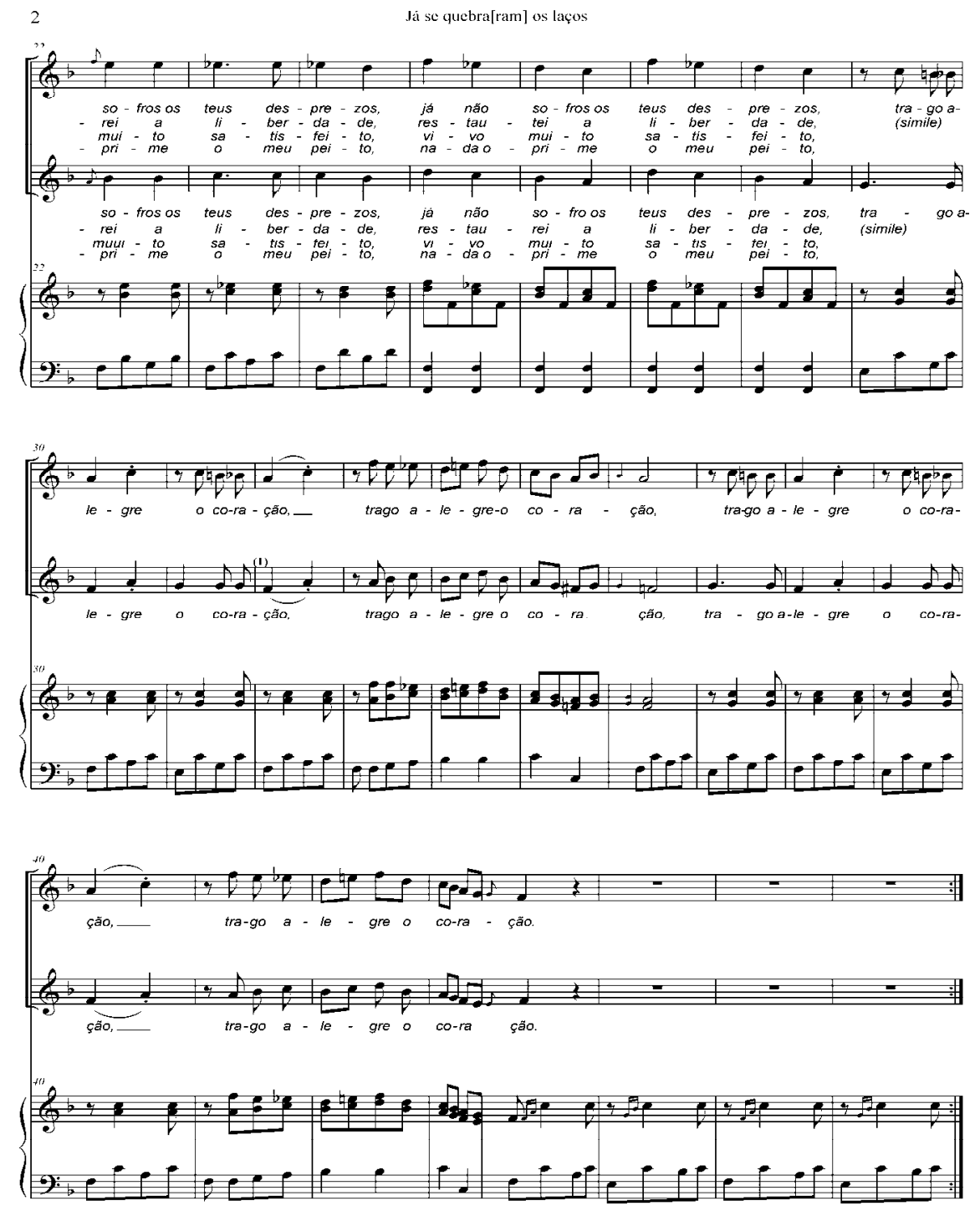

Já se quebram os laços, Jornal de Moinhas (ALBUQUERQUE, 1996)

O lundu $A$ saudade que no peito (LIMA, 2001, p. 137-40), construído em uma forma binária, onde a segunda parte funciona como uma espécie de coda. Possui uma primeira parte (cc. 5-12), contendo oito compassos composta por duas frases de quatro compassos iniciadas em anacruse. Essa mesma estrutura formal será repetida mais duas vezes com pequenas variações ornamentais no final das frases. No compasso 33, uma nova seção é iniciada a guisa de coda, estendendo-se até o compasso 43, contendo, portanto onze compassos. Essa seção poderia ter finalizado no compasso 39, somando, portanto, sete compassos. Mas o autor a estende, expandindo o motivo final por mais quatro compassos, dentro de um procedimento 
também bastante utilizado pelos compositores da segunda metade do século XVIII ${ }^{77}$. Outra característica desse lundu é a presença da introdução que acompanha todas as repetições da A. Além disso, o autor efetua um pequeno final instrumental, conduzindo a peça para a dominante, finalizando suspensivamente. Merece ser frisado inclusive, que todas as frases desse lundu, finalizam suspensivamente, ou seja, na dominante do tom, e esta não será uma tendência isolada, mas várias peças desse códice mantêm essa característica. ${ }^{78}$

\section{A saudade que no peito}
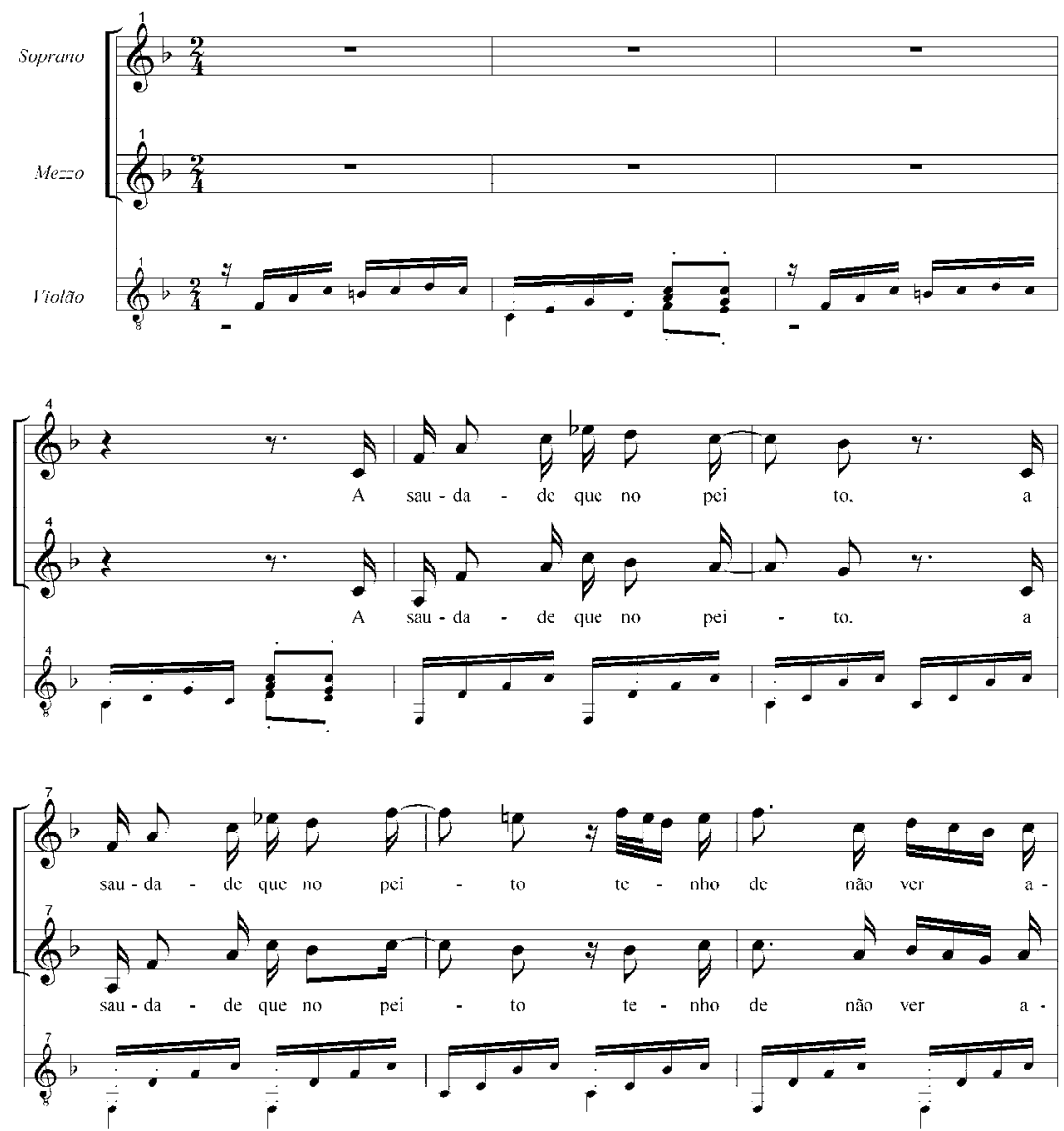

77 Segundo STEIN (1979, pp. 28-36), muitas das irregularidades fraseológicas ocorrem “ por razão de extensão, ou mais raramente, por contração" (p. 28), de outro modo, "muitas frases de mais de quatro compassos se comportam desta forma por causa de alguma extensão" (p. 30), seja efetuada no início ou no final da frase que, de outro modo, se comportaria como uma frase regular.

78 Para uma lista completa das peças que finalizam suspensivamente, pertencentes ao Ms 1596 Modinhas do Brasil, consultar LIMA. Edilson V. As modinhas do Brasil. São Paulo: Edusp, 2001, pp. 3839. 
Modinhas do Brasil - Edilson de Lima
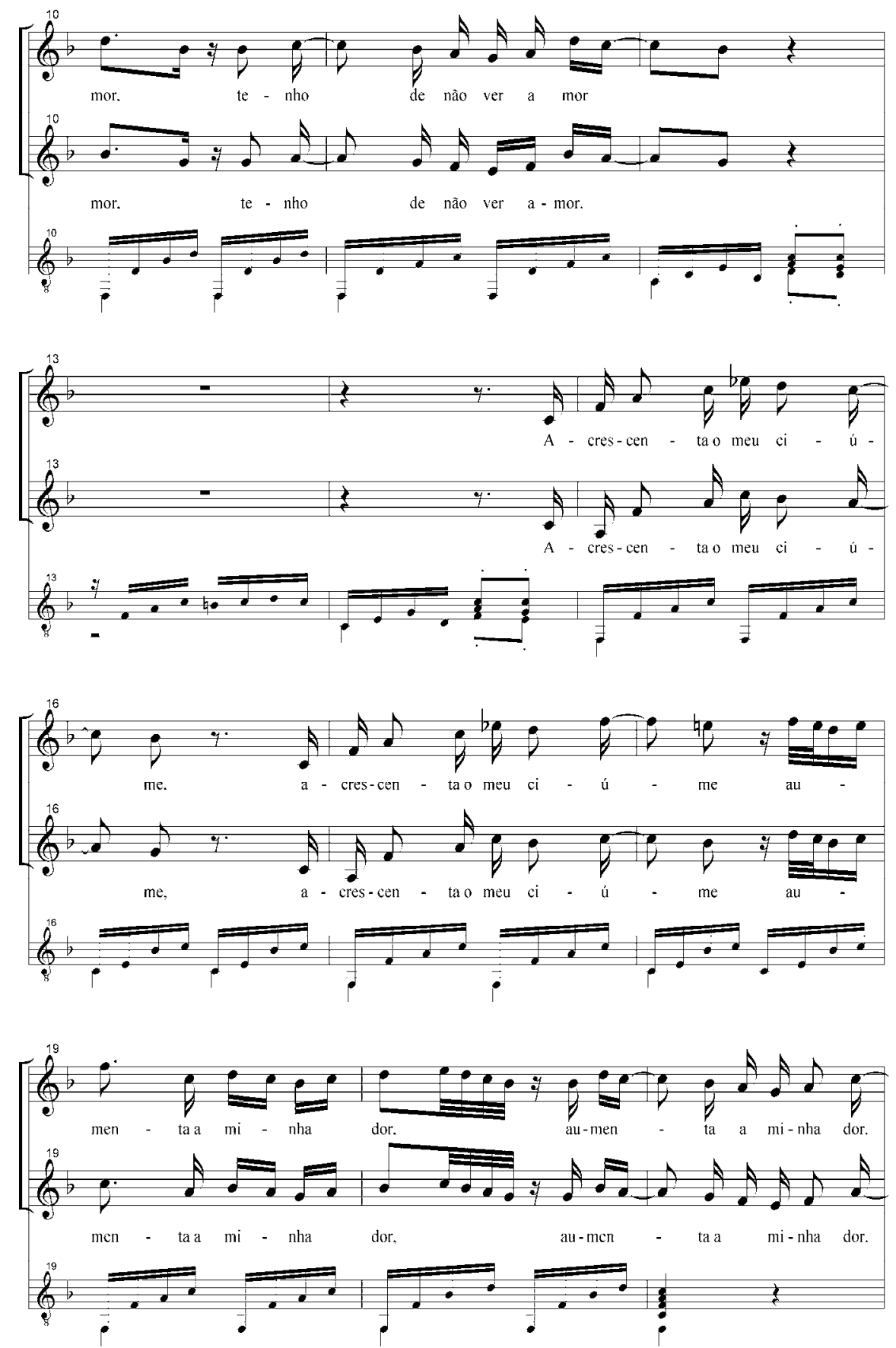

(c) 1999 by Edilson de Lima

44 

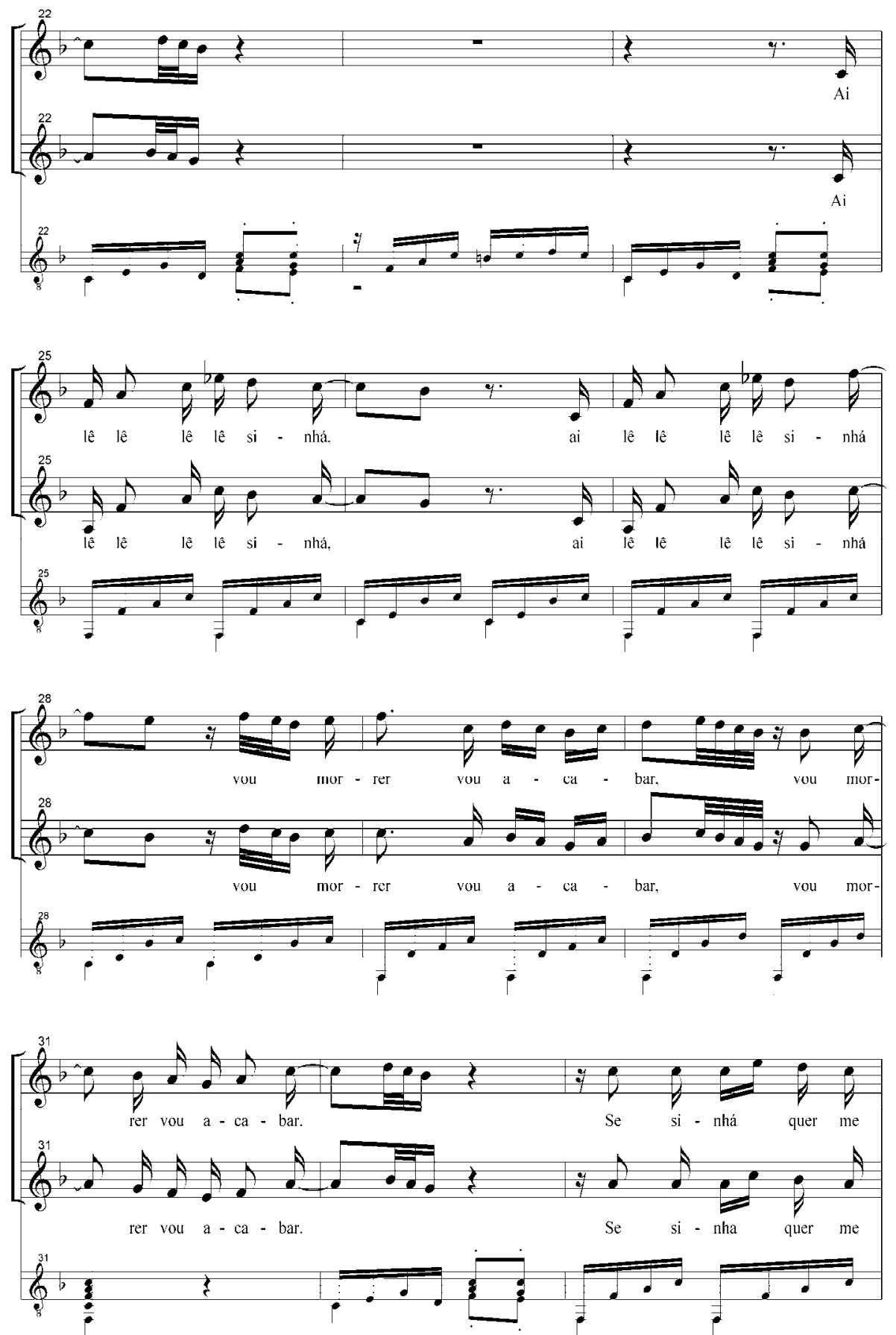

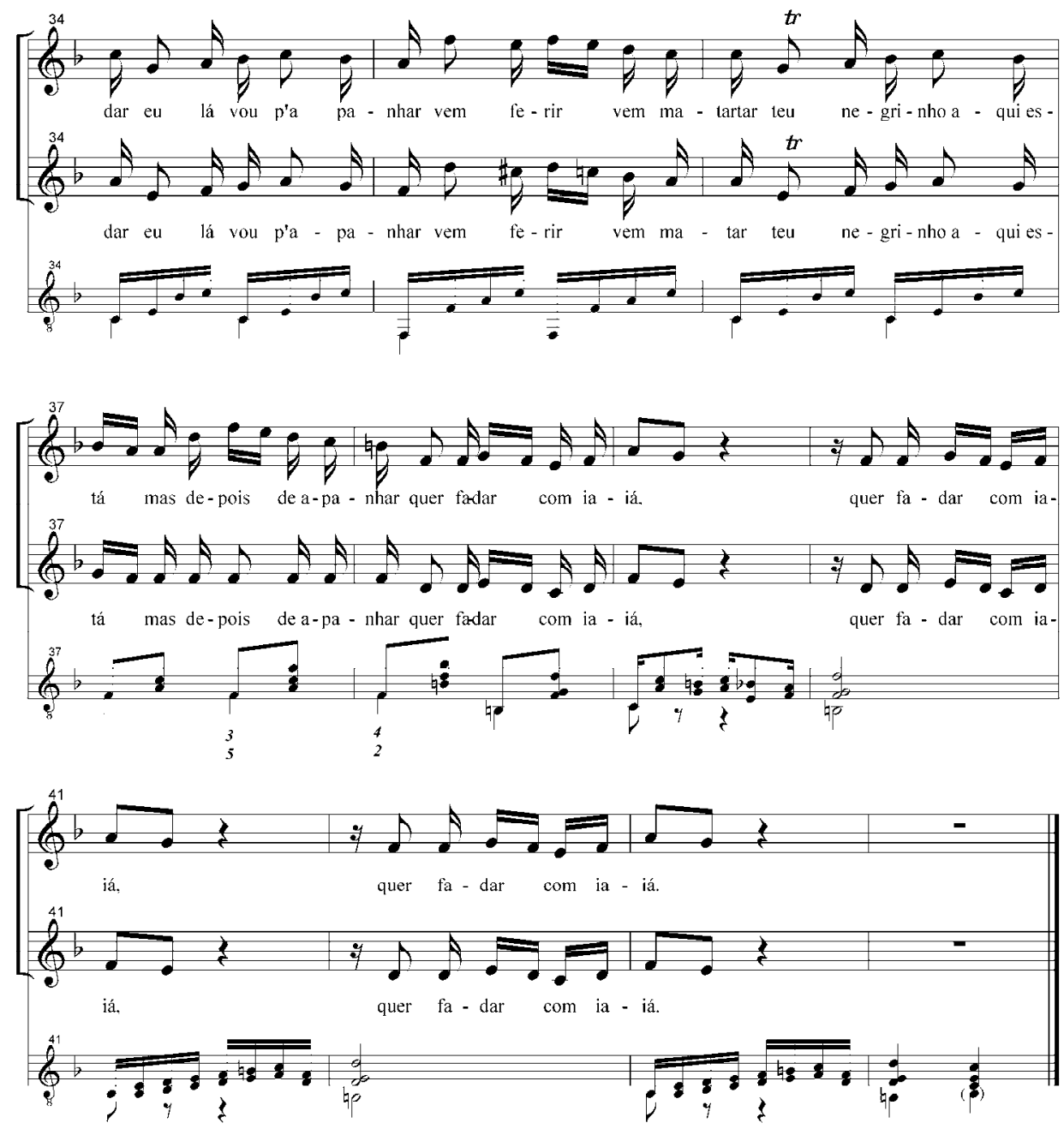

A saudade que no peito, As modinhas do Brasil (LIMA, 2001)

Merecem destaque dois lundus, Dizem que sou borboleta, pertencente ao arquivo Curt Lange do Museu da Inconfidência de Ouro Preto, e o lundu Eu já não sou criança, pertencente ao acervo da Biblioteca Nacional do Rio de Janeiro. Apesar de esses dois lundus terem sido compostos em meados do século XIX, distanciando-se de nosso foco principal, ambos estão escritos em compasso binário composto (6/8) e não apresentam o universo da cultura negra: ambos falam do amor em um sentido bastante idealizado, sem as laiás e loiôs. Porém, ambos foram classificados, já em sua época, como sendo lundus: 

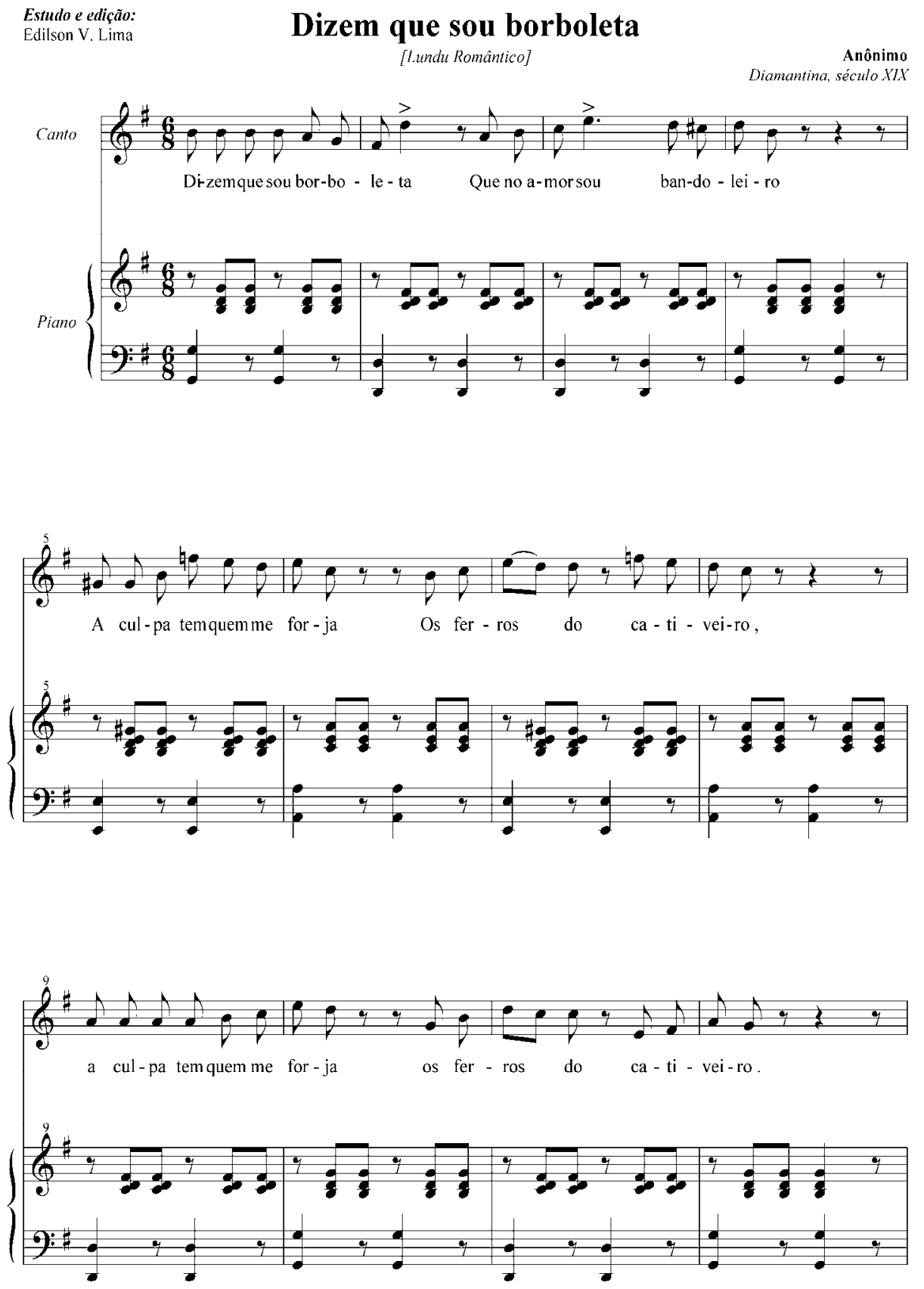

02008 by Edilson 1 Lima

8

Dizem que sou borboleta (trecho), Arquivo Curt Lange, MIOP - Ouro Preto 


\section{Eu já não sou criança}

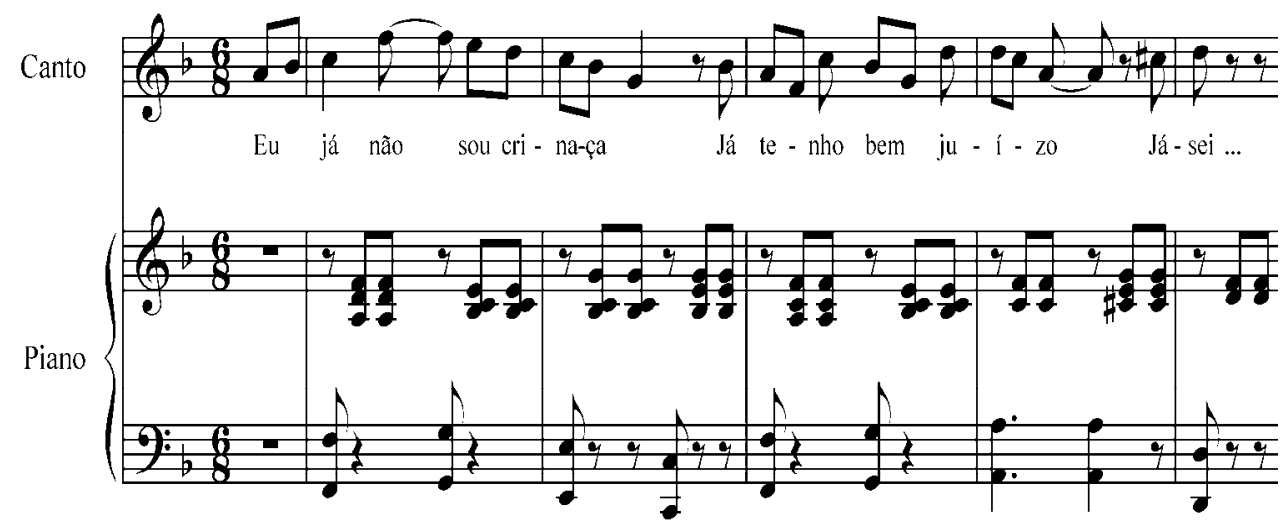

Eu já não sou uma criança (trecho), Biblioteca Nacional (RJ)

Mas, o que nos chama atenção, é que no apêndice do livro de Spix e Martius, a peça Uma mulata bonita (p. 300), antecipa em pelo menos vinte anos essas características e, como as duas peças precedentes, bem poderia ser classificada de lundu. Nesta peça, inclusive, a presença da mulata, pode corroborar esta conclusão. A hipótese que aventamos, é que todas essas peças poderiam ser interpretadas com bastante liberdade agógica, transformando as divisões ternárias do compasso composto em divisões binárias como se estivessem escritas em compasso binário simples ( $\sqrt{\sigma})$, ao gosto dos lundus comentados acima. Mas como ficou dito, isso é uma hipótese; ainda que não totalmente impossível de ser realizada.

Nesse sentido, o lundu Prazer igual ao que sinto (SPIX, 1981[1821], p. 298) pode ser bastante revelador, pois, alterna, dentro de uma métrica binária (2/4) as tradicionais tercinas efetuadas na unidade de tempo com sequências de figuras pontuadas e semicolcheias, dando a essa peça uma balanço bastante saboroso. Além disso, a opção pelos versos em redondilha maior na quadra e seguidos por um refrão com verso de oito sílabas, e também a presença do cognome de tratamento yayá (sic), conferem a esta peça o perfil inconfundível de um lundu. Portanto, este lundu parece funcionar como um elo (encontrado) entre os lundus Uma mulata bonita, Dizem que sou borboleta e Eu já não sou criança. 

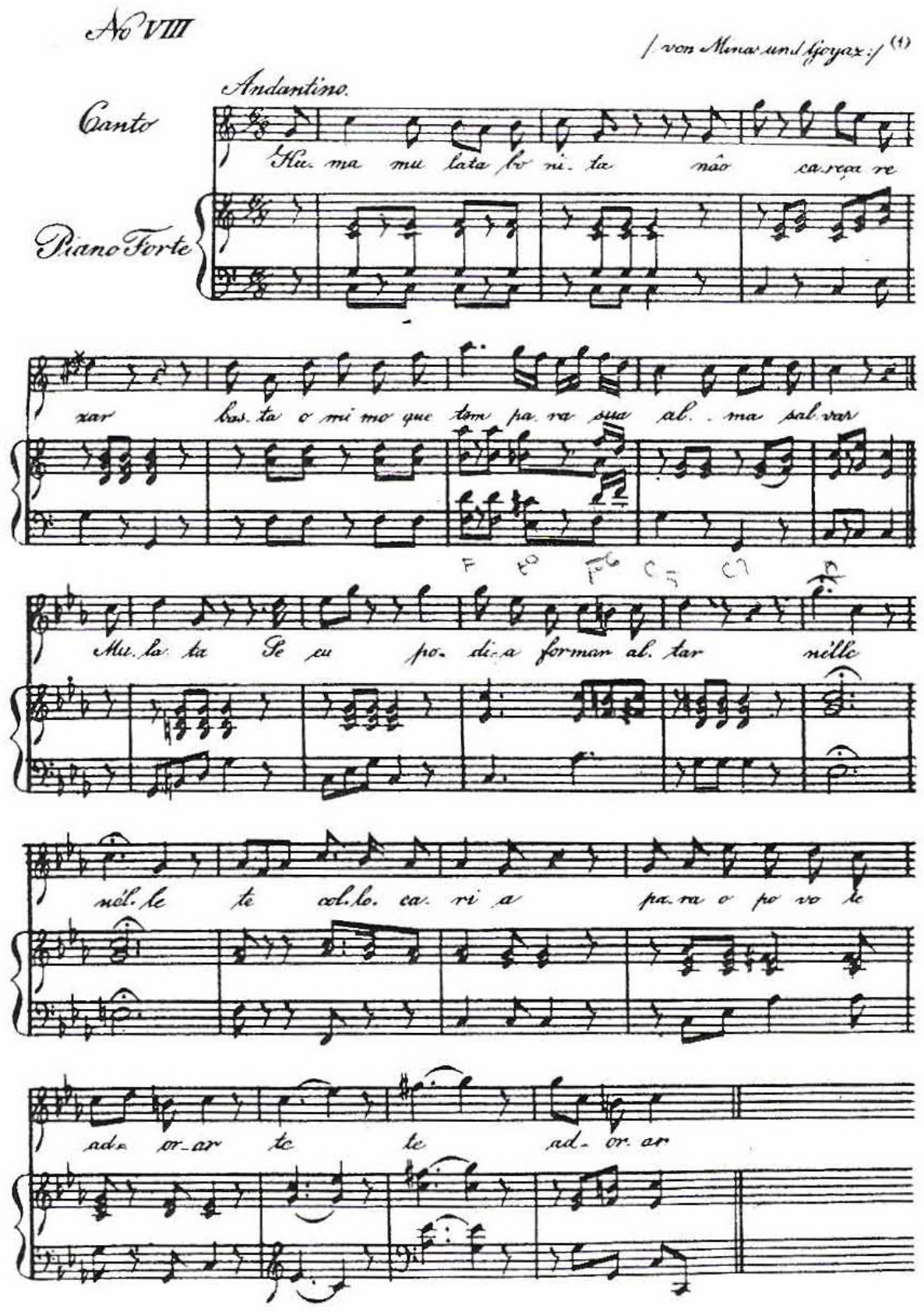

1 de Minas e Goiás.

300

Uma mulata bonita, Viagem pelo Brasil (SPIX, 1981[1821) 

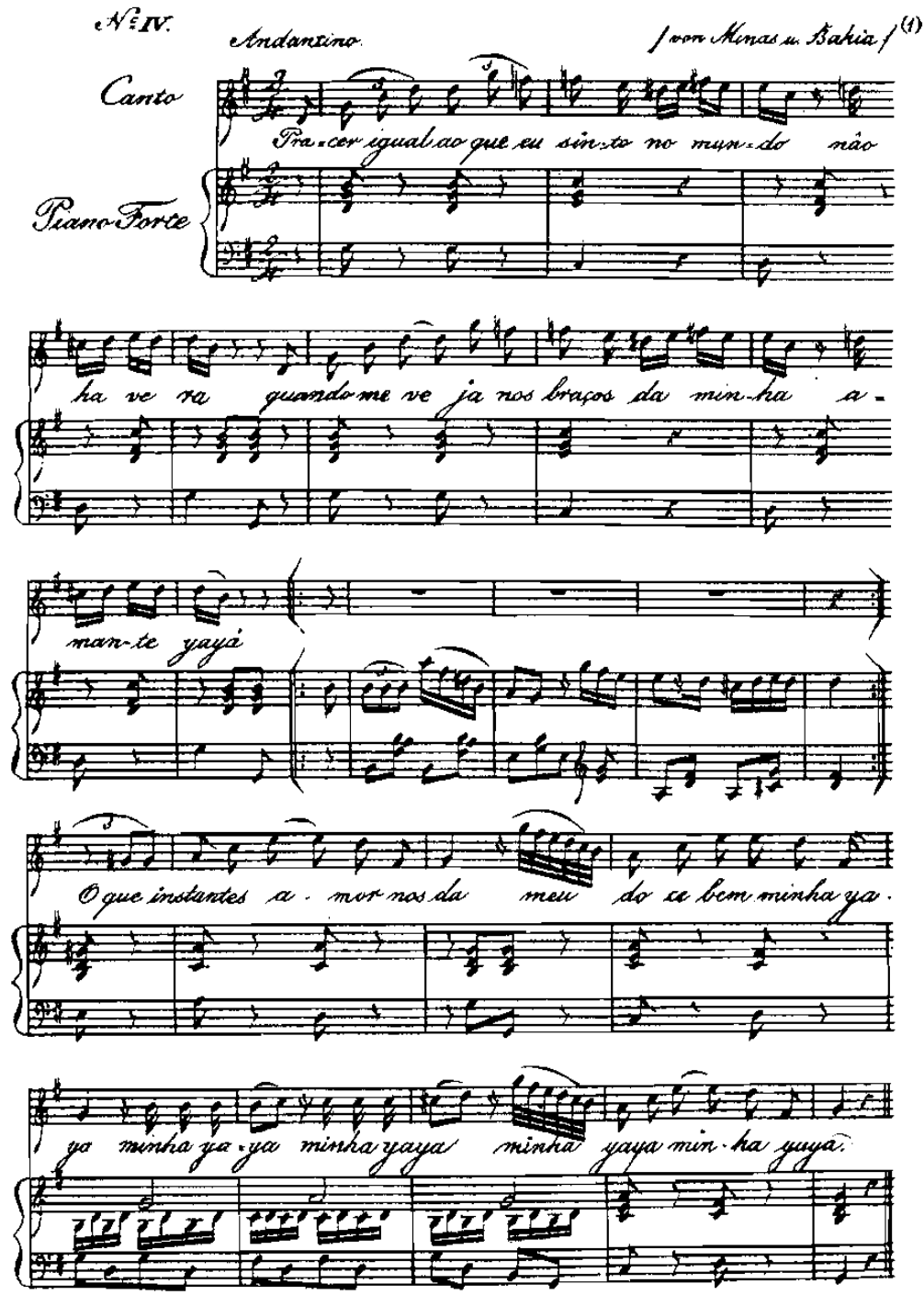

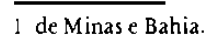

Prazer igual ao que sinto, Viagem pelo Brasil (SPIX, 1981[1821])

Mas, retornando ao epicentro de nossa época, o lundu, tanto em sua forma cantada como os instrumentais ligam-se perfeitamente às conquistas formais que dominaram a música a partir de meados do século XVIII e que irão formar um conjunto estilístico denominado Período Clássico, que englobam algumas tendências, como a música galante, o estilo sentimental, ou Empfindsamer Still e o estilo classicismo vienense inaugurado por Haydn (BURKHOLDER, 2006, p. 481). Mesmo que o mais conhecido de todos os lundus, Brasilian Volkstanz, e alguns dispostos no códice de Morretes (BUDAZS, 2002) ainda se utilizem de frases assimétricas, essas características constituem-se, na verdade, de tendências ainda galantes ou rococós, 
mas já consideradas dentro do estilo clássico. Ou seja, resquícios de um formalismo galante, ainda não totalmente simétrico. E de modo algum necessitamos invocar os velhos guitarristas do século XVII, tais como Gaspar Sanz, e muito menos os do século XVI, como Luiz Milan, por exemplo, pois entendemos que essas peças, mesmo que incorporem o improviso como elemento de linguagem estão absolutamente dentro de uma tradição já vinculada a uma musicalidade do século XVIII; frisemos, já eminentemente dentro de pressupostos pertencentes ao que se convencionou chamar período clássico.

Neste aspecto, o que pretendemos destacar na verdade, é que o lundu, não só surgiu na colônia brasileira e existiu como uma manifestação a partir da segunda metade do século XVIII, e nisso concordamos com vários autores ${ }^{79}$; mas também que, ao longo de sua trajetória galgou várias regiões e também perpassou as várias camadas sociais do sistema colonial luso-brasileiro, pois apesar de dançado por negros e mestiços, seja ao som do batuque, ou da viola ou do teclado, foi incorporado pela classe média, galgando, em pouquíssimo espaço de tempo, a corte, como afirmou Tomás Antonio Gonzaga em sua Carta Chilena (Cf. GONZAGA, 2006[1786], p. 156); e isto, não obstante as críticas negativas de moralistas da época ${ }^{80}$. O que nos incomoda, o grande enigma, neste caso, é que apesar do sucesso do lundu-dança aquém e além-mar, não encontramos partituras anteriores ao século XIX. Dito de outra forma: porque músicos dessa época, mesmo os amadores, não se preocuparam em fixar em partitura a música de tão venturosa dança?

\subsubsection{A dança do lundu e a ausência de partituras}

Apesar das primeiras notícias sobre a dança denominada lundu, terem surgido a partir da segunda metade do éculo XVIII, não há, como afirmado acima, nenhum registro da música que servia de suporte para a coreografia que acompanha a dança anterior ao advento do século XIX. Ao contrário, o primeiro registro em partitura foi efetuado entre 1817 e 1820 por Martius e Spix por ocasião da viagem empreendida às terras do Brasil a fim de efetuarem pesquisa sobre a fauna e a flora brasiliensis (MARIUTS \& SPIX, 1981[1821]). Na partitura que se encontra no apêndice da publicação consta apenas a melodia e, diferentemente das demais peças não há identificação da região onde fora recolhida. No lugar aonde viria esta identificação, consta apenas a informação "Brasilian Volksdanz" (dança popular brasileira), e não

\footnotetext{
${ }^{79}$ Cf. ARAUJO (1963), KIEFER (1977), J. R. TNHORÃO (1991[1974], 1998, 2004), MORAIS (2000), LIMA (2001 E 2006) e NERY (2005),

${ }^{80}$ Cf. ARAUJO, Mozart, A modinha e o lundu no século XVIII. São Paulo: Ricordi, 1963
} 
dança carioca ou dança baiana, por exemplo. O que parece indicar é que lundu foi, sem dúvida, uma manifestação que transcendeu os limites regionais. De qualquer modo, trata-se do registro mais antigo da música que acompanharia a dança do lundu.

A hipótese que aventamos, levantada na primeira parte deste texto, é de que os lundus instrumentais que serviam de suporte para a dança homônima eram improvisados e o início de uma função era marcado pela simples alternância entre tônica e dominante efetuando arpejos num tom confortável, ou por algum tema tocado no instrumento como a rabeca ou semelhante. Durante a dança do lundu, as palmas podiam corroborar, ajudando na marcação do ritmo padrão, juntamente com um ou mais instrumentos percussivos. Já a presença de um coro entoando um refrão ${ }^{81}$, efetuado pelos participantes envolvidos na manifestação, poderia ou não ocorrer, sem prejuízo da evolução da dança:

"Para que possam ser bem tocados, é necessário que haja dois instrumentos, uma das quais toca apenas o motivo ou tema, o qual é sempre um bonito e simples arpejo; enquanto a outra improvisa sobre este os mais deleitáveis melodias. Nestas ocasiões, dá-se a imaginação a maior e mais rica liberdades possível e ocasionalmente pode ser que sejam acompanhadas por voz; nestes casos é usual que sejam também improvisadas" (A.P.D.G, 1826, pp. 220-221).

Nesse aspecto, os lundus comentados acima, e descrição do venturoso viajante que esteve além e aquém-mar, constituem excelentes exemplos de como se estruturavam musicalmente e sobre qual sonoridade se desenvolvia a dança homônima. Acreditamos também que, na medida em que eram praticados por camadas mais distantes dos ciclos cortesãos e dos salões das classes médias, os dançarinos tinham mais liberdade para desenvolver suas coreografias e se manifestarem, não sejamos ingênuos, com maior liberdade. E a incorporação de instrumentos de percussão ou outros instrumentos, só viriam a enriquecer uma determinada função!

\subsubsection{A questão da síncope}

A questão da síncope, por mais que queiramos superá-la, ou transformá-la em uma discussão de cunho ideológico e, portanto em um embate político, diga-se de passagem, nem sempre ilegítimo, sempre esteve associada aos escritos do lundu. No

\footnotetext{
${ }^{81} \mathrm{E}$ já que tocamos em assunto de importância estrutural para o futuro dos lundus cantados, o refrão será uma constante nos lundus cantados após $1800 \ldots$, e se tornará verdadeira entidade na caracterização dos saborosos lundus de J. F. Leal, Padre Teles, Xisto Bahia, por exemplo.
} 
entanto, retornando ao mundo musical, mesmo que concordemos com Mário de Andrade em seu Ensaio sobre a música brasileira publicado em 1928:

"E será também uma pobreza si se tornar obrigatória. A sincopa é uma das constâncias porém não é constante nem imprescindível não. Possuímos milietas de documentos folclóricos em que não tem nem sombra de sincopado" (ANDRADE, 1962[28], p. 38).

Porém, ao levantar a questão de que uma suposta identidade musical brasileira não pode se fixar na existência ou não da síncope musical, a sua presença, ou seja, o deslocamento rítmico entre acentos métricos convencionais e não convencionais, como entendido tradicionalmente na música ocidental, será uma espécie de característica chave para a classificação da modinha e do lundu como gêneros autônomos entre os séculos XVIII e XIX (LIMA, 2006, pp. 101-114).

De fato, os dois gêneros em questão nascem irmanados e, sobretudo se levarmos em conta aspectos não só musicais, mas também sócio-culturais. É evidente que o ideal português era, sem sobra de dúvidas, transformar o Brasil em um imenso Portugal, integrado em um grande império colonial. Porém, uma política de tal magnitude não poderia ser empreendida sem a criação de estruturas administrativas locais. E a construção de estruturas político-administrativas na colônia incorporou, evidentemente, essa sociedade (SOUZA, 2006). Acreditamos, portanto, que foi nesse contexto que a modinha e o lundu puderam se influenciar mutuamente. Ou dizendo de outro modo, foi nessa conjuntura que traços culturais advindos de algumas etnias, sobretudo aquela em zonas mais ligadas ao tráfico negreiro (MUKUNA, 2006) puderam influenciar e engendrar outros gêneros musicais, como o lundu. $E$ de modo algum pretendemos com essa afirmação simplificar as relações humanas do final do século XVIII, sobretudo, deste lado do atlântico. Pelo contrário, pretendemos apenas integrar parte dessa complexidade em sua faceta musical.

A síncope tem sido citada nesse trabalho e, sobretudo nesse capítulo, de um modo absolutamente tradicional, ou seja, como ela foi convencionada pela teoria tradicional advinda da cultura ocidental: "O deslocamento regular de cada tempo em padrão cadenciado sempre no mesmo valor à frente ou atrás de sua posição normal" (GROVE, 1994). Mas, para que haja a sensação de um deslocamento, faz-se necessário um pulso regular e, o que seria mais importante, uma métrica regular ${ }^{82}$, que no caso da música ocidental foi instituído em uma fórmula de compasso. De qualquer modo, essa maneira de entender a organização rítmica está absolutamente vinculada à maneira como o ocidente organizou seu pensamento musical: ou seja,

\footnotetext{
${ }^{82}$ Pulso: A series of regularly recurring, precisely equivalent stimuli; métrica: The number of pulses between the more or less regularly recurring accents (COOPER AND MEYER, 1960).
} 
como um agrupamento sincopado (irregular em relação a uma métrica regular) se contrapõe a um agrupamento regular; e que há, portanto, outros modos de interpretar agrupamentos rítmicos regulares e irregulares. Mas essa idéia só poderá ser desfeita se admitimos "que a síncope não é um conceito universal da música" (SANDRONI, 2001, p. 21).

O que interessa frisar, é que na música ocidental (a partir, sobretudo das teorias da música mensural) os agrupamentos rítmicos são obtidos a partir da divisão (regular ou irregular) do pulso ou tempo. Porém, pesquisas em etnomusicologia vêm questionando esse modo de se obter agrupamentos rítmicos e, por consequência, analisá-los. Na música de origem africana tradicional, por exemplo, agrupamentos são obtidos a partir de processos aditivos e não por divisão de tempo ou pulsos. Ou seja, não se estabelece uma fórmula de compasso; mas pulsos que servem de guias (timeline) para as organizações rítmicas e métricas. Portanto, o que para o ocidente musical constitui uma irregularidade, para certas culturas não ocidentais, como a africana, não seria encarado como tal (SANDRONI,2001, p. 24). Aliás, essa interpretação já havia sido anteriormente levantada por Mário de Andrade em seu Ensaio sobre a música brasileira (1962[1928], p. 36): "E pela adição de tempos, tal e qual fizeram os gregos na maravilhosa criação rítmica deles, e não por subdivisão que nem fizeram os europeus ocidentais com o compasso...". De qualquer modo, o que queremos enfatizar é que a síncope é um conceito absolutamente ligado ao modo como o ocidente desenvolveu seus pressupostos rítmicos musicais.

Foi nesse sentido que o etnomusicólogo Mieczyslaw Kolinski, ao estudar a música africana, elaborou os termos cometricidade, para padrões que estão em acordo com o nível métrico; e contrametricidade, para padrões que estão em desacordo com o nível métrico (SANDRONI, 2001, p. 21). Outra categoria importante para a análise do time-line, ou linhas guias, já mencionada acima é a sucessão de pulsos sucessivos que funcionam como guia (SANDRONI: 2001, p. 25), como "um ponto de referência constante pela qual a estrutura da frase de uma canção, assim como a organização métrica linear da frase são conduzidas" (MUKUNA, 2006, p. 93).

Na música africana, há uma infinidade de padrões, mas alguns se relacionam mais proximamente com os lundus dos séculos XVIII e $X X^{83}$. Descrevo abaixo os padrões rítmicos mais comuns descrito por SANDRONO (2001) e MUKUNA (2006).

\footnotetext{
${ }^{83}$ Cf. MUKUNA, K. Contribuição Bantu na música popular brasileira: perspectivas etnomusicológicas. São Paulo: Terceira Margem, 2006.
} 
1.

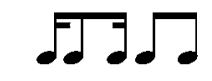

2.

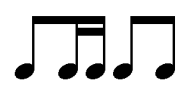

3.

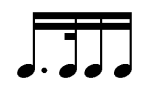

4.

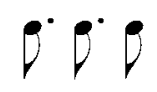

Estes padrões rítmicos são encontrados abundantemente, sobretudo dentro dos limites das barras de compassos em lundus no século XVIII (também em modinhas) e em lundus do século $X I X^{84}$. Evidentemente que esses padrões serão combinados dando origem a melodias mais longas, na elaboração de frases que ultrapassam os compassos; o que de fato irá ocorrer. O agrupamento 1 é encontrado já nos primeiros compassos da modinha Você se esquiva de mim (LIMA, 2001, pp. 6164) e se estende por toda a peça, como uma espécie de motivo padrão que ora é combinado formando frases totalmente contramétricas, ou sincopadas na linguagem convencional, como nos compassos 7- 8. Porém, ao analisarmos a partitura, percebemos o quanto a peça abusa de construções métricas e contramétricas dando um aspecto ora marcado, ora inconstante à modinha, sobretudo se levarmos em consideração o acompanhamento da viola, onde o arpejo constante disposto em semicolcheias faz o papel de "linha guia" (time-line).

\section{Você se esquiva de mim}

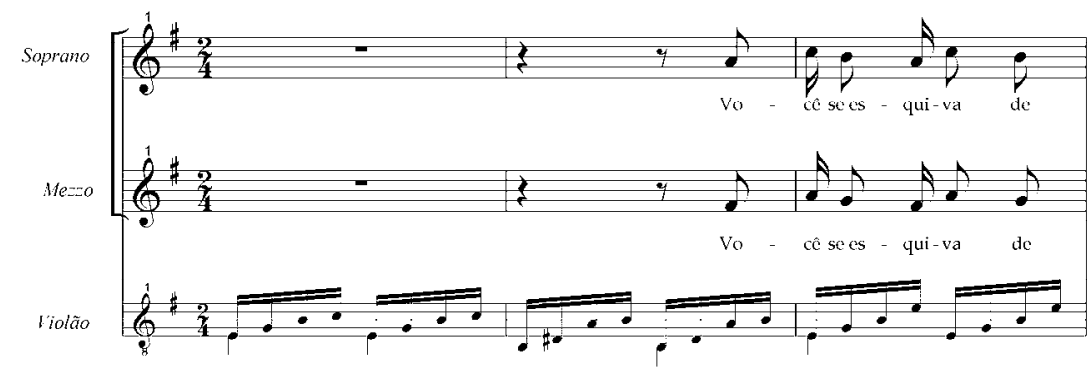

\footnotetext{
${ }^{84}$ Para nossa discussão, apesar das teorias sobre agrupamentos métricos e rítmicos, dos conceitos de cometricidade e contrametricidade e do conceitos de time-line, não abandonaremos os conceitos tradicionais de compasso e divisão rítmica desenvolvida na música ocidental. Sobretudo por entendermos que esta maneira de organização musical não foi descartada. Ao contrário, houve uma adaptação entre tendências da música negra e música ocidental no período em que estamos estudando. (SANDRONI, 2001)
} 

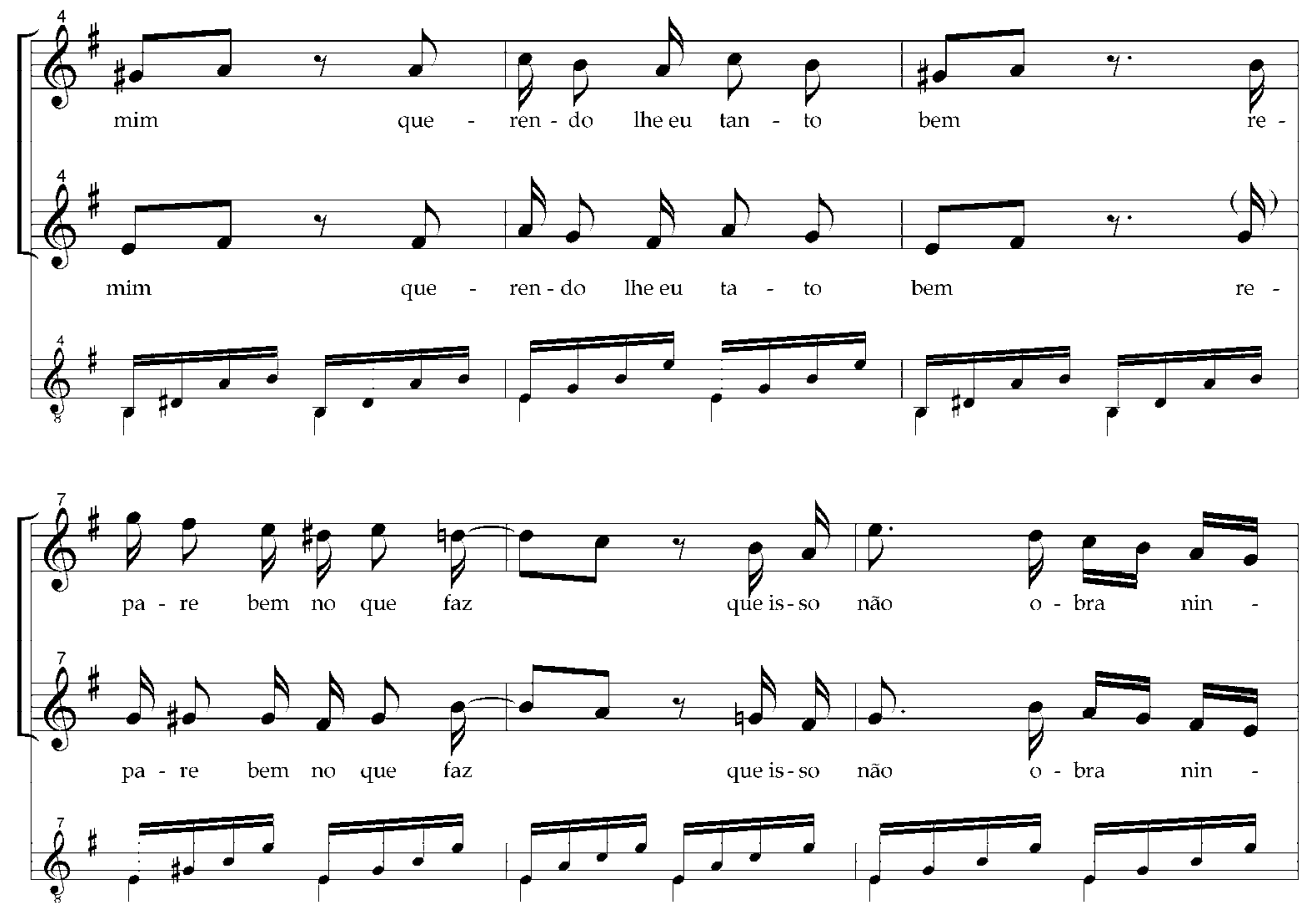

Você se esquiva de mim (trecho), Modinhas do Brasil (LIMA, 2001)

Outras peças do mesmo códice vão se comportar tal e qual a modinha acima, como por exemplo, o lundu Os me deixas que tu dás (LIMA, 201,. pp. 81-84): logo no início, entre os compassos 3 a 8, após a pequena introdução em arpejos dispostos em sequências de quatro colcheias à guisa de "linha guia" (v. ex. p. 174), a melodia está disposta em uma frase totalmente sincopada, ou dito na linguagem de Kolinsky, contramétrica (SANDRONI, 2001, p. 21). A partir do compasso 9 o compositor efetua sequências cométricas dispostas em semicolcheias articuladas de duas em duas, estendendo até o compasso quinze...

O lundu Eu nasci sem coração (LIMA, 2001, pp. 87-88) uma espécie de pedra de toque e já analisado anteriormente, inicia com uma frase de quatro compassos (cc. 4-7) totalmente contramétrica em relação aos arpejos da viola (linha guia), dando realmente, uma sensação de flutuação em relação aos acentos métricos convencionais do compasso binário efetuados pelos baixos dos acordes da viola ( $\mathrm{v}$. ex. p.181). Ao repetir a frase, efetua uma variação ornamentada em coloraturas, desta feita, cométrica, somente quebrada entre os compassos 12 e 13 e entre 14 e 15, a fim de efetuar as tão famosas terminações femininas. Estas terminações, enfatizemos, justamente como as terminações das duas partes da frase precedentes, combinam a terminação feminina, em tempo fraco do acento métrico do compasso, ora em antecipação, ora em retardos, suavizando de tal modo a resolução melódico- 
harmônica, que a denominamos de terminaçãos "mais que femininas" (LIMA, 2001, p. 21).

Outros lundus, como por exemplo, Menina você que tem e Esta noite, ambos de J. F. Leal, e também o lundu Lá no largo da sé de Cândido Inácio da Silva, estes já do século XIX, irão apresentar as características destacas nas peças anteriormente analisadas relacionadas com a questão das frases contramétricas dentro de estruturas musicais cométricas. Porém, o Lundum Brasilian Volkstanz (ver ex. p.171) não apresenta na partitura escrita nenhuma tendência a contrametricidade. Pode ser que isto ocorresse no ato da interpretação instrumental, sobretudo se houver um segundo instrumento encarregado da harmonia e deixando o solista com maior liberdade, como destaca Mário de Andrade, "ninguém não canta a música talequal anda impressa" (ANDRADE, 1962. p. 22). Porém, em um dos lundus apresentados no livro de Budasz, - Primeiro lundu da Bahia (ver ex p. 172), a síncope, de modo bastante sutil, é efetuada em uma variação do padrão rítmico no 1 (cc. 9 e 10).

Em outro lundu bastante conhecido de pesquisadores do gênero, o Lundu de Marruá (www.bn.pt), não há sincopes, apesar de seu nome deixar bastante claro a qual gênero pertence. Acreditamos que este lundu, deve ter sido dançado nos salões mais abastados e, seguramente, serviu de mote para os músicos efetuarem variações sobre o tema, e estas, bem ao gosto clássico:

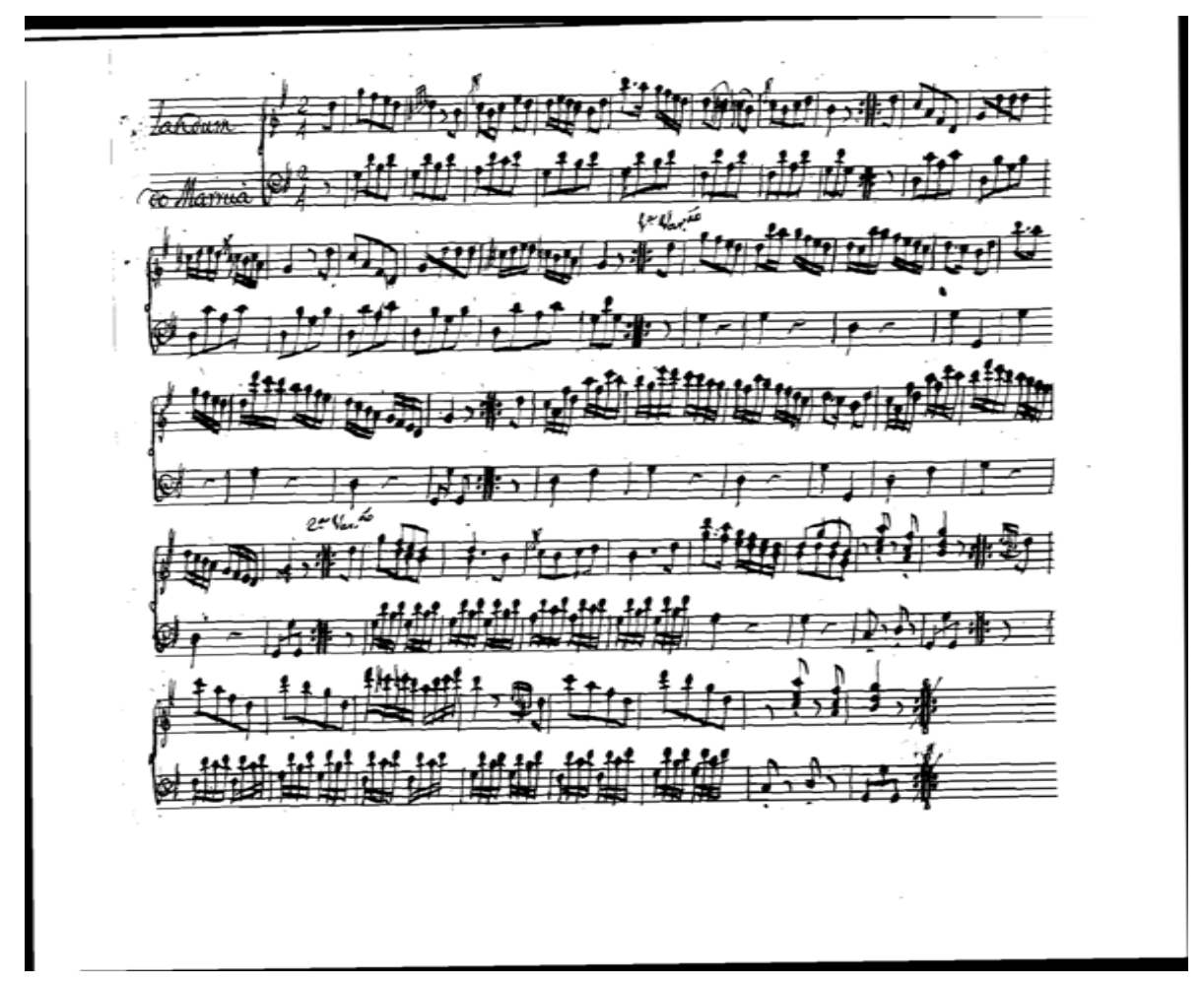

Landum do marruá, Biblioteca Nacional de Lisboa (PT) 
Este lundu, frisemos, parece ter sido um verdadeiro sucesso na passagem do século XVIII par o XIX, pois, além da versão em Sol maior apresentada acima como duas variações, e da versão em Ré maior do livro de Budasz (2002, p. 50), outras duas versões pertencentes à Biblioteca Nacional de Lisboa: uma em Bb maior, onde consta apenas a indicação Thema - And ${ }^{e}$ Sostenuto (sic) contendo cinco variações virtuosísticas e um Final; a outra, ainda mais virtuosística e contendo treze variações, trás não somente o nome da peça como seu autor e lugar: Variações do Landum da Monrois Compósto pòr D. Francisco da Bôa Mórte Conego Regulár em S. Vicente de Fora e' 1805 (sic) $)^{85}$ :

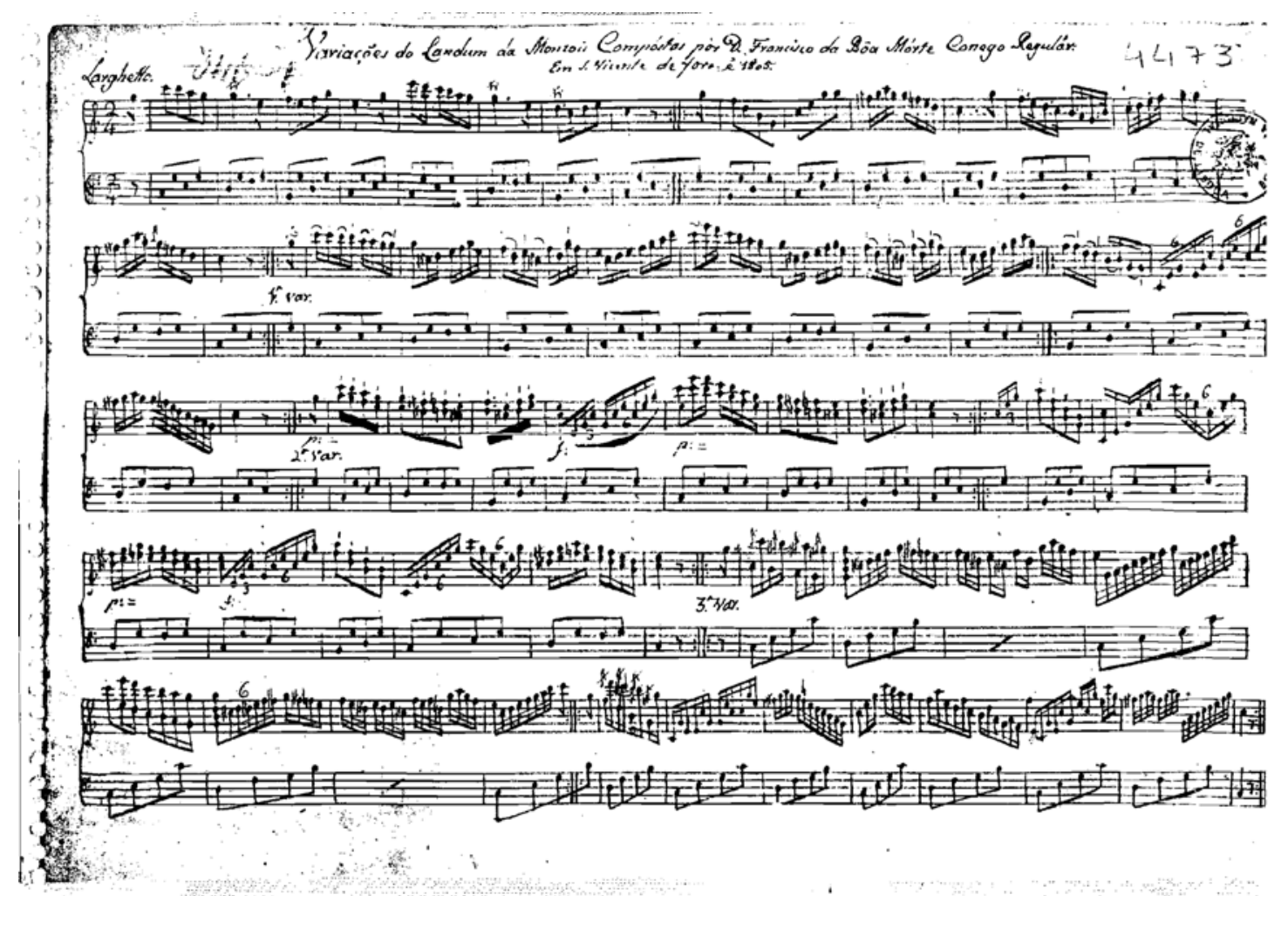

Variações do Landum da Monrois (trecho), Biblioteca Nacional de Lisboa (PT)

Neste aspecto, parece que fica difícil afirmar que os lundus, seja instrumental ou o lundu canção, têm origem nos improvisos dos guitarristas ibéricos (espanhóis), como quer Castanha (2006): se o improviso ou variação adentram a formação do lundu, estas parecem ser apenas algumas de suas características. Mas o que deve

\footnotetext{
${ }^{85}$ As três versões comentadas acima pertencem a Biblioteca Nacional de Lisboa e catalogadas respectivamente com os $\mathrm{n}^{\mathrm{os}}$ : versão em Sol maior, M.M 4473; verões em Dó e Si bemol maior, M.P. 523 v.
} 
ser também considerado, é que a questão formal e as opções por frases articuladas e periódicas, tanto em lundus instrumentais como em lundus cantados, com ou sem variação, concorrem em sua formação. E note-se que falamos de formação, construção e não de origem, como se um gênero cultural correspondesse a um organismo predeterminado e definido em seu código genético.

Outro fator é que após as discussões de Sandroni e Mukuna, fica bastante difícil não reconhecer a herança negra na formação musical do lundu, como afirmou Castanha (2006). Nesse aspecto, a presença da "síncope" seria mais do que um modo de "amolecer" as divisões rítmicas; mas verdadeiras combinações estruturais, de padrões e ciclos rítmicos, utilizados na elaboração do lundu como gênero. Portanto, aquilo que num primeiro momento é interpretado como um simples deslocamento métrico-rítmico mostra-se como uma combinação de tendências musicais advindas da cultura negra presente no Brasil nos lundus, e algumas modinhas, na segunda metade do século XVIII, dando origem, por sua vez, a outro gênero musical.

Merece ser destacado que ao identificar a "síncope" com a cultura negra no Brasil colonial, não estamos querendo antecipar as tendências nacionalistas de fins do século XIX e início do XX. Não cremos que nessa época os luso-brasileiros, reinóis mestiços e a população negra, almejassem uma autonomia política para a colônia brasileira; mas cremos que almejavam reconhecimento social e, portanto, cultural, ou seja, alforria; e isto já teria sido bastante humano, mas não demasiado. Desse modo, querer minimizar a contribuição musical negra na formação do lundu é negar a força estrutural de modos de construção rítmico-melódicos presentes em outras culturas e sua força estrutural na elaboração de formas musicais.

\subsubsection{O lundu canção: ornamento-monumento}

Levando em consideração as discussôes, até o momento, não faz mais sentido defender que o lundu seja apenas um subgênero da modinha, como afirma Ruy Vieria Nery (NERY, apud, MORAIS, 2000, p. 17). Evidentemente que em sua forma cantada, como música de salão e posteriormente nos entremezes sete e oitocentistas, ele absorverá os modelos vigentes na segunda metade do século XVIII, e tal e qual a modinha, será elaborado dentro dos padrões formais vigentes na época. Em nossa visão parece mais preciso afirmar que tanto a modinha quanto o lundu, serão "subgêneros" das tendências classicizantes que invadirão todas as esferas da expressividade musical durante o século XVIII, adentrarão o século XIX e se 
estenderão como força motriz, ou como concepção estético-poética que norteará parte da produção musical até o alvorecer do século XX (BLUME, 1954, p. 9). ${ }^{86}$

Outra questão defendida por nós, é que mesmo não encontrando partituras anteriores ao século XIX (1817), a estrutura dos lundus parece obedecer à forma tema e variação, ou tema e improviso ${ }^{87}$, mas já dentro de padrões musicais clássicos. Nesse aspecto, o relato de SPIX \& MARTIUS (1981[1821], p. 180), é bastante esclarecedor: "Dura às vezes, aos monótonos acordes da viola, várias horas sem interrupção". O que entendemos, é que "monótonos acordes da viola" são as "eternas" alternâncias arpejadas efetuadas pelo instrumento de cordas dedilhadas, enquanto outro instrumento (flauta, violino ou mesmo uma outra viola, como descreveu A.P.D.G.), efetua as variações. E embora esse relato tenha sido efetuado na passagem da primeira para a segunda década do século XIX, ele se assemelha muito a outras descrições, tais como a efetuada pelo poeta Tolentino de Almeida efetuada entre 1779 e 1780, onde a frase "tocar por pontos" (Cf. cap. 2) tem o sentido de dedilhar, portanto, combinando com a citação precedente ${ }^{88}$.

Um terceiro diferencial seria a presença da "síncope" que, mais do que um "amolecimento" da rigidez rítmica e métrica na música da época, é uma verdadeira adaptação de tendências estruturantes presentes na musicalidade negra, a saber, nos padrões e ciclos rítmicos, combinadas e adaptadas ao formalismo clássico. E é justamente nesse sentido que a síncope deixa de ser apenas um ornamento para tornar-se um verdadeiro monumento: passa a ser, também, um dos traços fundadores de um gênero autônomo: o lundu! ${ }^{89}$

\subsection{5. $O$ batuque e o lundu}

\section{Concordando com José Ramos Tinhorão (2008, p. 55),}

"tal como o exame mais atento das raras informações sobre essas ruidosas reuniões de africanos e seus descendentes crioulos deixa entrever, o que os portugueses chamaram sempre genericamente de batuques não configuram

\footnotetext{
${ }^{86}$ Nossa visão é que, mais do que um "Período Clássico-Romântico", nós devemos observar as tendências clássicas que continuam vigentes durante o século XIX, ou Período Romântico, não obstante outros modelos de composições, como a música programática, por exemplo, menos calcada em aspectos musicais autônomos.

${ }^{87}$ Cf. nesta tese: Lundum, Brasilian Volkstans e Primeiro da Bahia.

88 José Ramos Tinhorão (1991, p. 16) interpreta "tocar por pontos" como sinônimo de ponteio, ou seja, modo tocado pelos violeiros nordestinos. Mas segundo a técnica setecentista, a frase tocar por pontos, tem é sinônimo de dedilhar, ou ferir as cordas nos pontos, ou os trastes da viola, segundo o livro de Paixão RIBEIRO, A nova arre de viola (Coimbra, 1789)

${ }^{89}$ Utilizo aqui a interpretação do filósofo Gianni VAttimo discutida em seu livro La fine della modenità, que tem base nos escritos de GADAMER, H. G. Verdade e método. Rio de Janeiro: Editroa Vozes, 1979.
} 
um baile ou um folguedo, em si, mas uma diversidade de práticas religiosas, danças rituais e formas de lazer."

E parecer ser esse o sentido dado a essa reunião por SPIX \& MARTIUS (1981[1821], p. 180):

"Quase por toda parte aonde chegamos à noite, éramos recebidos com as toadas de violas, a cujo acompanhamento se cantava ou dançava. $\mathrm{Na}$ estiva, uma quinta solitária, com vastos campos magníficos, circundada ao longe de montanhas isoladas, estavam os moradores em festa, dançando o batuque (...). O batuque é dançado por um bailarino só e uma bailarina, os quais, dando estalidos com os dedos e com movimentos dissolutos e pantomimas desenfreadas, ora se aproximam, ora se afastam um do outro. O principal encanto dessa dança, para os brasileiros, está na rotação e contorções artificiais da bacia (... ) Dura às vezes, aos monótonos acordes da viola, várias horas sem interrupção, ou alternado só por cantigas improvisadas e modinhas nacionais..."

Ou seja, numa reunião desse tipo, tudo podia acontecer! De qualquer modo, a descrição acima parece se referir à dança do lundu, tal e qual a conhecemos hoje. Porém, nos interessa também que os ilustres viajantes foram convidados a participar da função assim como, acreditamos, os senhores reinóis e sua família, desvelando, se não o aspecto sincrético da reunião ou pelo menos certa tolerância. Além disso, estamos aqui já no alvorecer do século XIX e há poucos anos da independência política do Brasil. Em todo caso, continuemos nossa viagem ao passado.

Na descrição de RUGENDAS, apesar de posterior, há uma diferenciação entre o batuque e o lundu:

"A dança habitual do negro é o 'batuque'. Apenas se reúnem alguns negros e logo se ouve a batida cadenciada das mãos; é o sinal da chamada e de provocação à dança. $O$ batuque é dirigido por um figurante; consistem certos movimentos do corpo que talvez pareçam demasiado expressivos; são principalmente as ancas que se agitam; enquanto o dançarino faz estalar a língua e os dedos, acompanhando um canto monótono, ou outros fazem círculo em volta dele e repetem o refrão. Outra dança negra muito conhecida é o 'lundu', também dançada pelos portugueses, ao som do violão, por um ou mais pares. Talvez o 'fandango', ou 'bolero' dos espanhóis, não passem de uma imitação aperfeiçoada dessa dança. Acontece muitas vezes que os negros dançam sem parar noites inteiras, escolhendo, por isso, de preferências, os sábados e as vésperas dos dias santos" (RUGENDAS, 1989, pp. 157-158).

Porém, ao analisarmos duas litografias de Rugendas, ambas intituladas Dança do Lundu (RUGENDAS, 2002: pp. 132 e133), a mesma cena é representada contendo brancos, negros e mestiços na primeira e negros e mestiços na segunda: qual delas teria sido totalmente idealizada?. Em uma terceira litografia, esta denominada Dança 
do Batuque (RUGENDAS, 2002, p. 134), há somente a presença de negros. Portanto, o que entendemos é que em uma situação de recolhimento, longe dos olhos controladores dos reinóis lusitanos, os negros podiam desenvolver a dança de um modo mais livre, mais próximo aos seus hábitos. Mas na convivência com outras camadas sociais, adaptar-se-ia, seguramente, á conjuntura. Interessante observar que Rugendas, parece inverter a origem do fandango e do bolero, como sendo o lundu: “Talvez o 'fandango', ou 'bolero' dos espanhóis, não passem de uma imitação aperfeiçoada dessa dança”. Em outra descrição, A.P.D.G (1826, p. 288) já comentada acima, o autor descreve o que chama de o "frenético landum dançado por um negro e uma negra", tornando ainda mais indistinto certas manifestações culturais de nosso passado colonial ou imperial, no caso, o batuque e o lundu.

Antecedendo ainda mais alguns anos, a descrição de Nuno Marques PEREIRA, em seu Compêndio narrativo do peregrino da América, obra do inicio do século XVIII, descreve um ruidoso batuque ouvido durante a noite que o fez deixar os aposentos. $O$ interessante nessa descrição é que se para nosso cronista o batuque se manifestava como uma "confusão do Inferno"; para o senhor, não passava de cantiga de ninar, enfatizando ainda mais a aceitação dos batuques por parte dos senhores da época:

"Não era ainda de todo dia, quando ouvi tropel de calçado na varanda: e considerando andar nela o dono da casa, me pus de pé; e saindo da câmara, o achei na varanda, e lhe dei os bons dias, e ele também a mim. Perguntou-me como havia em passado a noite? Ao que Ihe respondi: Bem de agasalho, porém desvelado; porque não pude dormir toda a noite. Aqui acudiu ele logo, perguntando-me, que causa tivera? Respondi, que fora procedido [devido ao] estrondo dos atabaques, pandeiros, canzás, botijas, e castanhetas; com tão horrendo alarido, que se me representou a confusão do Inferno. E para mim me disse o morador, não há cousa mais sonora, para dormir com sossego." (apud TINHORÃO, 2008, pp. 43-44).

Outra descrição citada por TINHORÃO (2008, p. 46-7), é que nas Minas Gerais da primeira metade do século XVIII, mais precisamente em 1734, na casa de um tal Gaspar Pimentel Velho, e mais a frente, na Bahia em 1735, as autoridades ordenam "uma batida policial em terras dos frades beneditinos", por estarem a permitir dança de negros em seus recintos. Outra notícia, também vinculada pelo mesmo autor, seria a proibição por parte do "licenciado Caetano Miguel de Moura 'o maldito desenfado' em sua jurisdição" (TINHORÃO, 2008, p. 48).

Nesse sentido, a descrição da 11a. Carta Chilena de Tomás Antonio Gonzaga (Gonzaga, 2006[1786], p. 156) constitui um verdadeiro manifesto ao aproximar 
elementos advindos das manifestações negras ao mundo da população branca (Cf. p. 22). E num trecho da carta mais abaixo, descreve:

"Fizemos esta noite um tal batuque:

Na ceia todos nós nos alegramos:

A carta é bastante reveladora, pois além da descrição da "dança venturosa", que mais tarde conheceremos com o nome de lundu, descrevendo minuciosamente os requebros e os trejeitos e até um possível diálogo que poderia ser cantado de improviso, como refrão, como na descrição de Spix \& Martius acima; efetua a crítica de que este tal batuque, ou esta reunião, saíra dos terreiros e casas humildes e adentrara à casa do senhor. Não seria de todo inocente argumentar que os senhores brancos, poderiam comparecer a uma função deste tipo caso ocorresse no terreiro da fazenda, ou mesmo mais perto da senzala, ou mesmo nos largos e nas estreitas ruas setecentistas, atestando a troca de valores culturais entre as diversas camadas sociais durante o século XVIII.

O que entendemos é que há certa liberdade no uso do substantivo, uma espécie de processo metonímico entre o conteúdo e o continente: o batuque é o lugar onde, ao som da percussão e outros instrumentos (violas, rabecas, buzinas, balafons, calimbas, etc.) dançava-se e cantava-se. A questão ainda é: quem ou o quê? Acreditamos que embora o termo batuque esteja ligado em sua origem ao mundo negro, incluindo os ditos calundus, haverá um contato entre as camadas negras, mestiças e reinóis, e desde os primeiros relatos. Estes encontros serão fundamentais para a formação de uma cultura luso-brasileira durante os primeiros séculos e também nos século seguintes. O próprio improviso, presente na parte instrumental e cantado, poderia ter sido praticado como elemento também na dança, conferindo uma liberdade sem precedentes aos negros dançarinos.

Entendemos, portanto, que será da estabilização dos elementos coreográficos presentes nesses batuques (entendido como reuniões, encontros com caráter absolutamente aberto) que se desenvolverá a futura dança dolundu. E acreditamos (ou temos a esperança) de que os negros tiveram seus momentos de intimidade, não sem muita dificuldade, onde puderam se expressar longe dos olhos controladores lusitanos, e objetivaram construir suas próprias identidades e sonharam com sua futura liberdade, também em sentido sócio-cultural. Portanto, e sem querer fazer apologia à democracia racial, este tão esperado porvernir, querer separar complemente essas manifestações e supostas camadas sociais durante os séculos 
XVIII e, sobretudo, XIX, parece ser um contra-senso, seria negar a complexidade e o dinamismo da sociedade luso-brasileira da época, empobrecendo sua riqueza. ${ }^{90}$

\subsubsection{O lundu instrumental pós 1817}

Diferentemente do final do século XVIII, em que não encontramos partituras de lundus instrumentais, durante o século XIX, além de lundus cantados compostos por músicos de renome, tais como Francisco José da Silva, J.F. Leal, Inácio Candido da Silva, lundus instrumentais serão compostos em maior profusão. Evidentemente, que o grande marco dessa produção, continua sendo o Lundum, Bralisian Volkstanz de Martius e Spix, porém, outras publicações contendo lundus instrumentais, irão surgir.

O códice Cifras de música para saltério, publicado por Rogério Budasz (2002) e já citado nas páginas anteriores, será de grande contribuição, pois além de vários gêneros da época, traz em seu conteúdo vários lundus instrumentais com as características acima discutidas: arpejos alternados entre tônica e dominante, ou temas para improviso, o que seria mais importante. Nesse sentido, sugerem ser lundus que serviram de suporte para a dança homônima. Será, inclusive, nesse códice onde encontramos umas das três versões conhecidas do Lundum de marruá: não nesse códice, mais nas duas versões pertencentes à Biblioteca Nacional de Lisboa, este lundu parece não ser mais para dançar, mais sim usado como um genuíno tema para variações (Cf. pp. 203 e 204) e, diga-se realmente de passagem, dentro de pressupostos absolutamente clássicos.

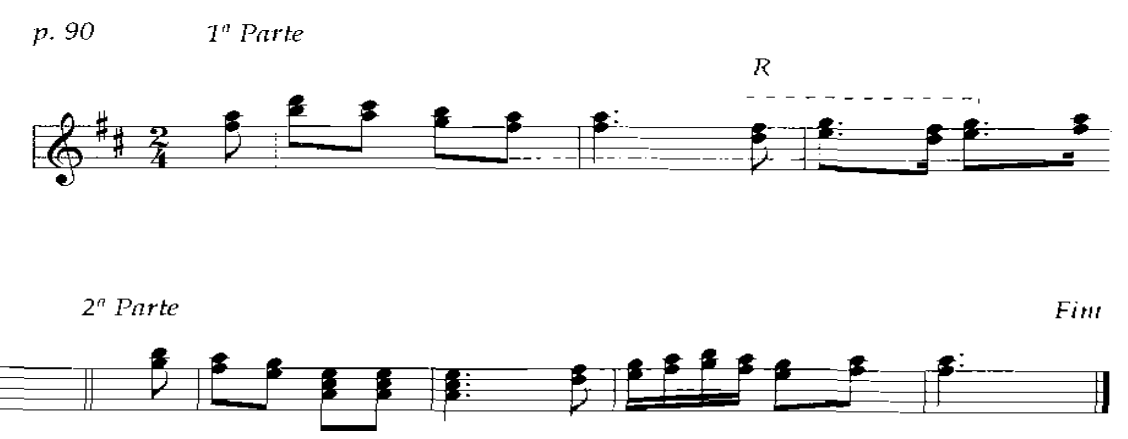

Lundum de Marruá, Cifras de Música para Saltério (BUDASZ, 2002)

\footnotetext{
${ }^{90}$ Cf.: Ruusel-Wood (2000); Sousa (2006).
} 


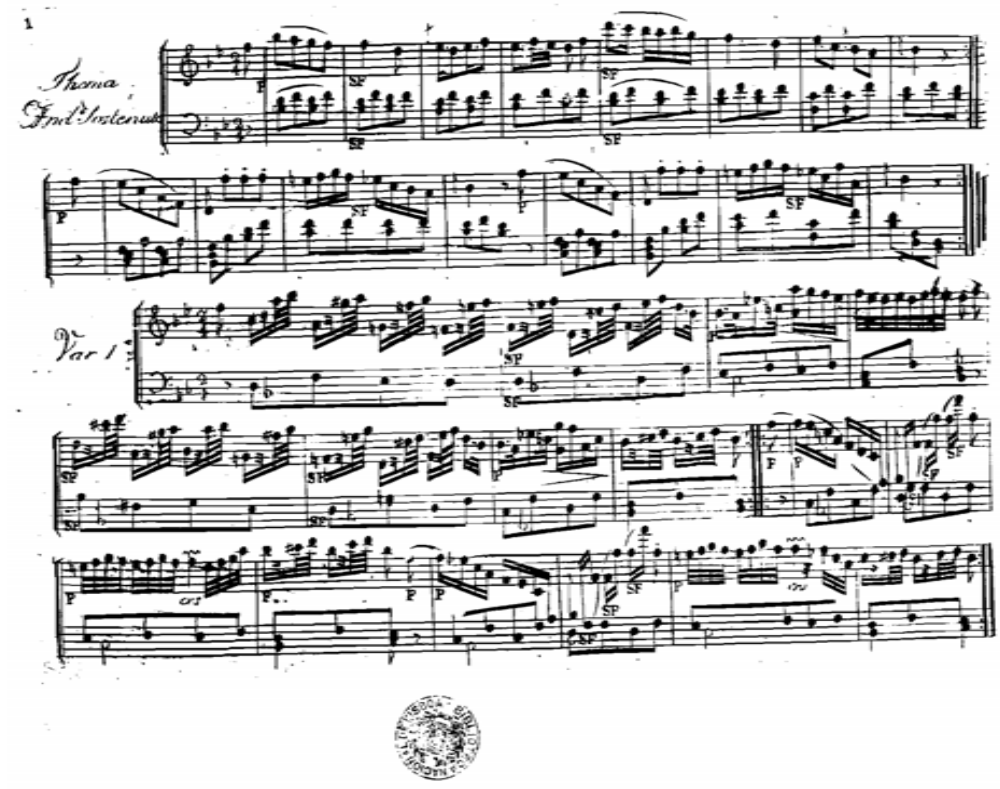

Lundum de Marruá, Biblioteca Nacional de Lisba.

Nesse aspecto, a coleção de lundus instrumentais da Biblioteca Nacional do Rio de Janeiro tem muito a nos revelar, pois, ao lado de edições de modinhas e lundus para canto e piano, nos apresenta aproximadamente quarenta lundus editados para piano entre 1837 e 1900 (SANDRONI, 2001, p. 57). Evidentemente que esta fase já não está mais no foco de nossas atenções e constitui apenas um olhar periférico. Mas de qualquer modo, não podemos nos furtar a alguns comentários, mesmo que passageiros.

As síncopes melódicas continuam em voga, mas nesses lundus, tendem a não se estender além das barras de compasso, situando-se dentro do limites do compasso. Talvez isso se deva ao fato de que não há um texto como elemento unificador entre música e fala. E neste aspecto, a "intuição" de Mário de Andrade sobre a relação entre síncope e ritmo prosódico do texto é muito interessante: "Os ameríndios e possivelmente os africanos também se manifestavam numa rítmica provinda diretamente da prosódica"... (ANDRADE, 1962[1928], p. 30). De fato, tendemos a concordar que os tipos de síncopes que encontramos no manuscrito da Biblioteca da Ajuda (efetuadas no tempo, no compasso, e às vezes em frase de até três compassos), constituem um verdadeiro banquete em diversidade.

Já no que diz respeito ao padrão de acompanhamento, há uma combinação

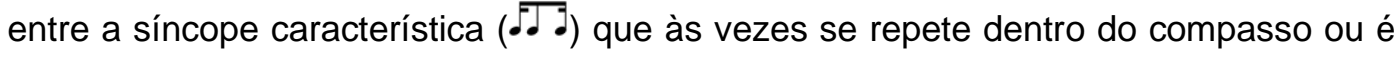
seguido por duas colcheias, e sua posterior estabilização no padrão da habanera (·. J). Já na questão formal, o tradicional tema e variação dos lundus Brasilian Volkstanz e o Primeiro lundu da Bahia (ver pp. 171 e 172), cederá lugar para formas 
binárias ou ternárias, mais próximos da contradança, da marcha e, sobretudo, da polca.

\subsection{Estilo e interpretação}

Seguindo a linha interpretativa desenvolvida nas páginas precedentes, a modinha e o lundu luso-brasileiros do final do século e início do século XIX, estão absolutamente ligados às conquistas do que foi denominado ao longo da história da música de estilo clássico, incluindo o estilo galante e, de certo modo, o estilo sentimental (Empfindsamer Still). Neste aspecto, acreditamos que a busca de uma consciência sonora vinculada, portanto, a esse período deve fazer parte de nossas preocupações interpretativas, mesmo na atualidade.

Porém, sabemos que ao longo dos séculos o ajuste entre os ideais sonoros vão sendo adaptados às conjunturas não somente epocais como locais. De outro modo não estaríamos preocupados, ainda hoje, com as diferenças, às vezes nada sutis, entre o estilo barroco francês e italiano que foram amadurecendo durante o século XVII e que alcançarão o seu apogeu no inicio do século XVIII, deixando marcas profundas na obra de Johann Sebastian Bach (1685-1750), George Friedrich Händel (1685-1759), JeanPhilippe Rameau (1682-1764), mesmo numa época onde Johann Stamitz (1717-1757) e Giovanni Battista Sammartini (ca. 1700-1775) davam início ao que será mais tarde transformado no estilo clássico.

É evidente que entre as concepções musicais barrocas e clássicas, há ideais que precisam ser destacados: enquanto os propósitos da música barroca estão absolutamente ligados à afirmação dos ideais políticos e nacionais; o ideal clássico, ligado ás concepções ilustradas, buscam em sua concepção de universalidade as bases para a construção de seus ideais sonoros. Portanto, se para o estilo barroco as afirmações de diferenças constituem um dos pressupostos chaves, para o clássico, a busca de identidades será uma das metas. Não estou afirmando que não existam "maneirismos" e que os autores do denominado Período Clássico não desenvolveram seus estilos pessoais; ou ainda que toda obra dessa época possa passar por anônima, independente do compositor. E concordando com Charles Rosen (1988: 24), "La magnitud del 
contexto no es un factor arbitrario, y preciso es distinguir entre el estilo de un pequeño grupo (...) y el estilo, un tanto más 'anónimo', de toda una época". Neste caso, um estilo pessoal "es una forma de utilizar el lenguage" (Idem, $25)^{91}$.

De qualquer forma, e se levarmos em consideração não somente quase um século que denominaremos de Período Clássico, se incluirmos os primeiros entremezes da primeira metade do século XVIII (BURKHOLDER, 2006: 473) e a persistência da concepção do "belo" como formalismo, simetria, clareza, por exemplo, o gosto clássico terá vida longa ainda no século XIX (BLUME: 1970). Por outro lado soluções pessoais na construção tanto de pequenas formas quanto de formas mais extensas, como as sonatas e primeiros movimentos de sinfonias, abundam durante o período destacado acima. Em suma, e ainda nas palavras de Rosen, "la unidad de estilo no es más que uma ficcíon que los próprios compositores contribuyen a confirmar" (ROSEN, Idem: 27$)^{92}$.

O que queremos afirmar, na verdade, é que o reconhecimento e fixação de um período devem estar alinhados com o reconhecimento de que há muitas forças internas, algumas mais concordantes e outras discordantes; e mesmo o reconhecimento de alguma corrente como sendo hegemônica (o ideal de universalismo e racionalidade do século XVIII, por exemplo), não descarta pensamentos, que num futuro não muito longínquo, poderão vir à tona e modificar o panorama expressivo. É nesse sentido que a corrente Empdfindamer Still antecipa, guardadas as devidas proporções, as buscas românticas no que tange à expressividade individual e a liberdade formal em música. Em suma, neste aspecto, Rosen se aproxima de uma interpretação bastante consistente, ao afirmar que uma história que busca uma unidade estilística, tende a se aproximar da ficção.

Por outro lado, descartar as forças de uma "época", não é de todo sábio! Mais uma vez nas palavras de Rosen, "En um sentido estricto, su obra no viene determinada por ella (época), pero si constituye la herramienta com la que tiene

\footnotetext{
91 "A grandiosidade do contexto não é uma fator arbitrário, e é preciso distinguir entre o estilo de uma pequeno grupo (...) e o estilo, um tanto mais 'anônimo', de toda uma época"; "é uma forma de utilizar a linguagem" (T.A.).

92 "a unidade de estilo não é mais que uma ficção que os próprios compositores contribuem em afirmar" (T.A.).
} 
trabajar, o contra la que ha de trabajar" $(1986: 62)^{93}$. E nesse sentido, as discussões "estéticas", filosóficas e científicas durante o século XVIII, têm muito a oferecer para o que viria a se convencionar como estilo clássico, e a busca de formalismo e simetria estariam muito alinhados com o entendimento da época; também a "simplificação do baixo", na verdade, constitui uma opção para o desenvolvimento de uma melodia mais complexa, aquela que carrega em seu interior as forças de sua própria transformação, a frase articulada, como discutimos no capítulo O classicismo europeu.

Ademais, o ingresso do sentimento ou sentimentalismo como categoria estética, distanciando-se do conceito de afeto barroco será imprescindível para o mundo das artes, e constituirá uma mudança de foco bastante importante. É evidente que estas categorias já atuam como base da música barroca, mas a tentativa dos pensadores da arte do século XVIII para um entendimento claro e racionalizado do mecanismo de recepção, não aqueles ligados ao mecanicismo cartesiano descrito em As paixões da alma de Descartes; mas uma tentativa de conciliar o racional (ou seja, as leis universais) e o real, às nossas percepções do mundo (EAGLETON, 1993: 19). E mesmo sabendo para que lado o pêndulo oscilará mais forte, o século XVIII abre uma perspectiva de unir, pelo menos nas discussões filosóficas da época, razão e sensibilidade. Discussão que se estenderá até os nossos dias e, diga-se de passagem, ainda com poucos frutos, sobretudo em nossa área de atuação: a música.

Portanto, ao interpretarmos a modinha e o lundu do último quartel do século XVIII e primeiro do XIX dentro do que se convencionou denominar de estilo clássico, é entender que a busca de um formalismo simétrico, a elaboração da melodia articulada, não são periféricos na elaboração desses dois gêneros, mas centrais; e identificados com a concepção de produção e recepção da época. Neste aspecto, os conceitos de natureza, racionalidade, simplicidade, como discutidos no capítulo segundo, participam ativamente na opção e elaboração das frases e formas, oferecendo obras que acreditavam estar mais próximas da percepção e entendimento do ouvinte da época. E de modo algum, insistimos, entendemos a elaboração da frase articulada clássica como uma simplificação musical, mas sim como uma mudança de foco: se para

\footnotetext{
93 "Em um sentido estrito, sua obra vem determinada por ela (época), e nesse sentido constitui a ferramenta com que tem que trabalhar, ou contra tem que trabalhar" (T.A.).
} 
o estilo barroco, o discurso harmônico norteia a estrutura da obra; no clássico, este estará subordinado à estrutura fraseológica e suas consequências. Nesse sentido, a frase articulada é uma das elaborações mais sofisticadas da história da música que norteará em parte os modelos fraseológicos futuros e, portanto, formais; e não só isso, sintetizará a busca de clareza e simplicidade, tão almejados no pensamento iluminista, e que farão parte, indubitavelmente, do conteúdo da estética, disciplina que nasce dessa necessidade: sistematizar o mundo da arte via razão e sensibilidade (JIMENEZ, 199: 58-9 ou 73).

No que tange à performance, ou às opções que serão efetuadas no palco ou em registros sonoros, penso que não podemos ser dogmáticos. Mas, se por um lado devemos ser abertos à liberdade de construções interpretativas; por outro, não podemos exigir que uma obra do final do século XVIII se comporte como uma obra de meados do século XIX, pois, haverá nos próximos anos mudanças, às vezes sutis e às vezes mais radicais, que nortearão tanto o fazer quanto a recepção. Portanto, uma compreensão da compreensão dos atores e obras de sua própria época é mais do que necessária, ou seja: quais são seus ideais estéticos, as concepções que norteiam as possíveis significações da época; e poéticos, queremos dizer, as técnicas que coordenam o fazer. Mas, mesmo esse problema deverá ser enfraquecido e de modo algum devemos entender que nossas propostas interpretativas tenham pretensões a se fixarem como normas definitivas; mas ao contrário, constituem possibilidades, construções e não prescrições ou bulas.

\subsubsection{História e interpretação}

A história, segundo as palavras de Keith Jenkins (2007), nada mais é do que um compromisso que os historiadores têm com seus respectivos campos teóricos, ou seja, com o âmbito epistemológico, metodológico e ideológico. Dizendo de outro modo, a história constitui um discurso "engajado" efetuado pelos historiadores, ou seja, é historiografia, escrita histórica; nesse sentido, passado e história constituem coisas diversas. Ou seja, "o passado sempre nos chega como narrativas e que não podemos sair dessas narrativas para verificar se correspondem ao mundo ou ao passado reais, pois elas constituem a 'realidade'” (Ibidem. 28). Neste caso: ou o passado existe como memória: as 
lembranças que nos constituem e não têm pretensões de se constituir em uma disciplina, mas sim compor nossa existência; ou como historiografia, ou seja, "um dentre uma série de discursos a respeito do mundo" (Idem 23).

Mas de modo algum a interpretação histórica, a historiografia, constitui algo arbitrário e puramente subjetivo. Embora o historiador (ou cientista) não possa sair de si em suas interpretações, sabemos que "somos muito mais determinados do que pressupomos" (MARTON, 2004, p. 23). Ou seja, seu compromisso com a disciplina, com um campo conceitual, com o método e com o que almeja para sua pesquisa, em suma, com o paradigma vigente, não o deixa atuar somente subjetivamente, arbitrariamente. E por paradigma, entendemos "aquilo que os membros de uma comunidade partilham" (KUHN, 2006, p. 221). E seguindo ainda os passos de Thomas Kuhn, uma comunidade científica "consiste em homens que partilham o mesmo paradigma" (Ibidem, p. 221).

O que pretendemos destacar com este conceito é que nem o cientista ou pesquisador age arbitrariamente, e nem a comunidade independe de seus cientistas. O que descartaria um mero "subjetivismo" na construção de uma interpretação. E é justamente por entendermos a interpretação como uma "clareira", um "entre" que se abre unindo o sujeito e o objeto, que o mero subjetivismo fica descartado. A interpretação histórica (assim como a interpretação artística; ou do músico frente a uma orquestra, ou ao seu instrumento; ou ainda em um grupo de música antiga) trata-se daquilo que o filósofo Hans-Georg Gadamer denominou de "fusão de horizonte": aquele que nos advém do passado, desvelado pela obra; e este, a partir do presente, orientado pelo pesquisador. Nas palavras de Gadamer, "O horizonte do presente não se forma, pois à margem do passado. Não existe
um horizonte de presente por si mesmo, assim como não existem horizontes
históricos a serem conquistados. Antes, compreender é sempre o processo de
fusão desses horizontes presumivelmente dados por si mesmos." (GADAMER,
1997, p. 404).

Dentro dessa perspectiva, a interpretação seria, portanto, uma compreensão que "implica a reconquista dos conceitos de um passado histórico de tal modo que esses contenham também nosso próprio conceber" (GADAMER, 1997, p. 488). Portanto, não se volta ao passado, mas reorientados por seus conceitos, idéias, características, o reinventamos a partir 
de nossas compreensões no presente. Dizendo de outro modo, o passado "se nos ilumina" no presente. Por isso reinventamos a todo o momento o passado, pois este, jamais conhecido em sua totalidade, se desvela à medida que o interpelamos. E quando assim agimos, já estamos inseridos dentro de um horizonte histórico, ou seja, onde passado e presente se completam.

Portanto, a função tanto do historiador, quanto do musicólogo ou do interprete de música, seja do passado ou do presente, insere-se dentro dessa perspectiva analítica: interpretar é "construir" uma escrita histórica (um texto, aula ou palestra; reconstituir uma partitura ou um modelo de performance) tendo como base os documentos de uma época e suas escolhas na atualidade, que de modo algum estão isentas de compromissos epistemológicos, metodológicos e ideológicos, como escrito acima. Tampouco os documentos de uma época estão isentos destes compromissos: também eles estão inseridos em seus horizontes históricos e foram efetuados por mãos comprometidas com mais coisas do que a "arte pela arte". E essa obsessão pelo documento, denominado de "realismo ingênuo" (SAMUEL, apud, JENKINS, 2007, p. 19), que denota uma espécie de fetichismo pelos fatos, como se estes falassem por si, e não pelos intérpretes. Neste caso, insistimos, o documento

"não é o reflexo do acontecimento, mas é ele mesmo um outro acontecimento, isto é, uma materialidade construída por camadas sedimentadas de interpretações: o documento é, assim, pensado arqueologicamente como 'monumento'” (JENKINS, 2007,p. 11).

Desse modo o que valida uma interpretação é sua inserção dentro de um horizonte comum (passado-presente) e seu pertencimento a uma comunidade privilegiada que compartilha um modelo interpretativo; e a fixação desse modelo, o paradigma, é que norteará a validade e a autenticidade de uma interpretação, portanto, um consenso de uma comunidade, seja esta científica ou de interpretes de música passada ou presente. E por sua vez, isso não ocorre fora de um horizonte histórico, ou seja, fora das condições conceituais e materiais de uma época, e sem ligação, enfatizemos, com anseios políticos, ou seja, fora de um horizonte ideológico!

Em nosso caso, o controle de um modelo interpretativo pode tanto gerar fomento para uma pesquisa, como o controle de um departamento e a criação de vagas; pode fundar as bases de um grupo de música antiga ou uma 
orquestra; em suma: controlar o paradigma é deter parte do poder. Desse modo, estudar o passado, elaborar e fixar modelos interpretativos no presente (como por exemplo, a "Interpretação historicamente informada", conceito que trataremos mais abaixo) é controlar o futuro (JENKIN, 2007, p. 41). E nesse aspecto, (fugindo dos conceitos de Hans-Georg Gadamer), estaríamos um passo adiante da interpretação; estaríamos em um jogo político que, para além da fusão de horizontes, pretende fundar modelos interpretativos e, portanto, fixar escolas, controlar instituições, buscar estabilizações conceituais, até que outros modelos venham a substituí-los, ainda dentro da lógica tradicional de superação.

De qualquer forma e mesmo dentro da lógica ainda tradicional da superação, os modelos interpretativos têm mudado: seja porque as conjunturas históricas mudam; seja porque que os modelos conceituais também mudam. Além disso, a entrada em cena após a segunda metade do século XX dos múltiplos sujeitos sociais produziu uma pluralização das narrativas históricas: história vista de baixo, história das mulheres, micro-histórica; e também a busca de outros enfoques, com as narrativas advindas dos romances ${ }^{94}$. Todas essas mudanças vêm conferindo à história um caráter plurívoco, onde um possível "processo unitário se dissolve" (VATTIMO, 1999, p. 13). Portanto, insistimos, a busca da eleição de algum modelo interpretativo como hegemônico na situação em que nos encontramos na atualidade (a diversidade da escrita histórica), parece ser uma atitude eminentemente ideológica; e mesmo que a história, melhor dizendo, a historiografia possa estar em migalhas (DOSSE, 2003), o retorno das "meta-narrativas", que está por ser reconquistada, se é que seja ainda necessária, não deverá excluir a diversidade da escrita histórica que foi liberada durante o século vinte.

\subsection{2. "Performance historicamente informada" ou o controle do paradigma interpretativo}

A fixação de modelos interpretativos, como discutido acima, não constitui uma contradição em si, mas aceitando como legítimas as correntes

\footnotetext{
${ }^{94}$ Para uma discussão mais abrangente desse aspecto, Cf.: ARÓSTEGUI, J. A pesquisa histórica. Bauru -SP: Edusc, 2006; BURKE, P. (Org.). A escrita histórica - novas perspectivas. São Paulo: Unesp, 1992. BURKE, P. O que é história cultural? 2ª Ed. Rio de Janeiro: JZE, 2008.
} 
historiográficas mais atuais, poderia ser encarada mais como uma vontade política. Sobretudo se reconhecermos os limites de nosso método, ou seja, os limites de nosso modo de compreender o mundo, que é uma das lições que os múltiplos enfoques históricos e a filosofia hermenêutica têm nos ensinado. Dito de outro modo, esta diversidade está ligada não só às potencialidades inerentes à obra de arte, especialmente quando atravessam os séculos e acumulam múltiplas interpretações; mas também ao engajamento dos historiadores e aos seus modelos interpretativos, ou seja, aos sistemas conceituais que sustentam o discurso historiográfico, e que por sua vez, estão inseridos em suas épocas legitimando seus modelos interpretativos, com base em uma historicidade que o valida.

Desta forma, e voltando nosso discurso para a interpretação musical, toda tentativa de fixar um estilo de performance (e que por sua vez tem sua própria historicidade, ou seja, é efetuado num estreito comprometimento com os vínculos históricos de sua época) como o único válido ou o mais correto, é uma maneira de negar a história dentro de um de seus mais caros pressupostos:

"pluralizar a História, democratizando-a e liberando-a das formas hierarquizadas e excludentes do pensamento identitário abrindo-a não só para múltiplos sujeitos sociais, mas para enfoques, acontecimentos, métodos e procedimentos diferenciados" (JENKINS, 2007, p. 11).

Agir de modo contrário é querer conferir à história um caráter unívoco, unidirecional, ao invés de plurívoco. A busca, portanto, de estabilização de um determinado modelo interpretativo, seria mais um exercício de "poética", ou seja, de prescrição (PAREYSON, 1997, p.: 15). Dizendo de outro modo, seria uma atitude política no sentido do exercício do poder, uma atitude ideológica. $E$ o controle do modelo interpretativo, neste caso, seria o controle de uma determinada área de atuação: escolha de obras e músicos; atuação em determinadas instituições etc..

Levando-se em consideração, portanto, que os modelos interpretativos se substituem, ou mesmo convivem, sobretudo em nossa época, perguntamos: o que valida um determinado estilo de performance musical? O que daria a essa ou àquela performance seu caráter de autenticidade? O estudo das fontes musicais? O estudo do pensamento da época?... Tudo isso com certeza! Mas o 
que devemos levar em conta é que não somente nós, na atualidade, estamos inseridos num horizonte histórico e, portanto comprometidos com nossa época; também um tratado ou manuscrito de época não constitui um retrato inocente, como se estes existissem fora da cultura, da sociedade, dos anseios políticos, portanto, fora da história. Mas os tratados também constituem discursos comprometidos com suas épocas, ou seja, "o mundo ou o passado sempre nos chegam como narrativas e que não podemos sair dessas narrativas para verificar se correspondem ao mundo ou ao passado reais, pois elas constituem a "realidade"' (JENKIN, 2007: 28). Desta forma, as narrativas (também os documentos e tratados de época) são construções, consistem também em interpretações, e não em uma descrição isenta de intenções e comprometimentos culturais, poéticos e estéticos e, portanto, políticos.

Reiterando: os tratados e textos elaborados no passado, tem que ser encarados como discursos, ou "práticas que 'sistematicamente constroem os objetos de que falam'” (BURKE, 2008: 102). Portanto não só analisam uma situação, mas também orientam modos interpretativos ligados a visões de mundo, intentam implantar novos "paradigmas"; ou seja, são também propositivos e num certo sentido, ideológicos. Queremos dizer com isso, que o estudo de documentos de época, que a nosso ver é de suma importância para formarmos uma linha de pensamento, tem que ser encarado como proposta de possibilidades interpretativas e não como "bulas" rígidas ou prescrições estáticas $^{95}$ ou ainda como retratos "fieis". A fidelidade, na verdade, é um compromisso com um campo conceitual (epistemologia), com o método, com ideologias, e com suas possíveis conseqüências. Nesse sentido, interpretar um documento do passado - no caso, uma obra do século XVII ou uma modinha do século XVIII - é entender, inclusive suas liberdades, suas dinâmicas e suas várias possibilidades orientadoras. Em outras palavras, a tarefa de todo intérprete musical e, inclusive do especialista em musica antiga, seria "que una interpretación histórica es casi siempre una interpretación de interpretaciones" (DALHAUS, 2003, p. 48) ${ }^{96}$, vista tão somente como abertura de possibilidades.

\footnotetext{
95 Para uma discussão mais aprofundada sobre o problema da autenticidade de um, ou conjunto de documentos, objetivo que fugiria à nossa proposta nesse texto, Cf. TARUSKIN. R . "The authenticity movement can become a positivistic purgatory, literalistic and dehumanizing", in Early Music, V. 12, No. 1. Feb., 1984, pp. 3-12.

96 "que uma interpretação histórica é quase sempre uma interpretação de interpretações" (T.A.).
} 
Desta forma, quando os expoentes do movimento da "performance historicamente informada" autorizam suas interpretações como autênticas: concordo! Eles estão dentro de um paradigma, tomado no sentido discutido por Thomas Kuhn (2006), ou seja, o modo como seguidores compartilham limites de uma disciplina; mas quando reprovam outras interpretações, sejam de outras épocas ou de outros grupos como inautênticas, isso soa estranho, para não dizer autoritário e positivista: autoritário, porque se autorizam a possuir a única interpretação válida, e neste caso, definitiva; positivista, por pensarem ter descoberto algo nunca antes conhecido, ainda dentro de uma visão objetivista e factual da história, como se o fato valesse como um retrato do passado; ou ainda, dentro do conceito do gênio clássico-romântico da estética kantiana que recebeu uma revelação da natureza (JIMENEZ, 1999: 134). E não que construíram (a partir de diálogos, no nosso entender, absolutamente válidos entre orientações do passado e do presente) um outro modelo de interpretação que, com o passar dos tempos (e não muito tempo, diga-se de passagem), pode vir a ser substituído por um mais novo, ainda num sentido tradicional de superação dialética; ou conviver com outros modelos também autenticamente válidos, ou seja, com outras "vozes" interpretativas. O que precisa ser entendido é que cada época, ou uma mesma época, constrói seus modelos de acordo com suas visões e necessidades históricas, suas concepções, engajamentos políticos e projetos ideológicos; e os efetua, queremos crer, com toda responsabilidade e autenticidade a partir de orientações vinculadas a seus modelos interpretativos, ou seja, dentro de um campo paradigmático.

Portanto, a minha crítica com relação à "performance historicamente informada" tem dupla articulação: uma, o reconhecimento da pluralidade interpretativa no que tange a música antiga; e por conseqüência o reconhecimento da autenticidade de outras interpretações do passado, ou mesmo do presente, sobretudo, quando estas se baseiam em pressupostos que validam suas opções, o que estou denominando "paradigmas interpretativos" e, conseqüentemente, também historicamente informados. Outra, a necessidade da revisão do conceito "performance historicamente informada": pois, o particípio passado "informada" destaca que tão somente eles possuem informações historicamente válidas sobre o passado e que suas opções são as únicas corretas; e que outras correntes e épocas não 
trabalharam dentro desses pressupostos, ignorando, não inocentemente, a "democratização" proposta por Jenkins (2007); ou uma possível "heteroglosia", ou seja, "as diferentes vozes que podem ser ouvidas em um texto" (BURKE, 2008. p. 72); em suma, negando uma história "plurívoca" (VATTIMO, 1999) e afirmando uma história em via única ou com um único telos.

\subsubsection{Interpretação e finitude}

Portanto a tarefa do historiador, seja este vinculado à performance ou musicólogo e, sobretudo, aquele mais atento a certas linhas de pensamento, como a hermenêutica filosófica, é destacar as possíveis significações, ou resignificações de uma determinada obra ou conjunto de obras. Por tal razão esta linha de pensamento não trabalha com a busca da "verdade" interpretativa no sentido estável, mas com a busca de uma possível verdade (HEIDEGGER, 1972). Dizendo de outra forma: aceita que a interpretação "é" provisória e que se trata "de aprender a fazer a experiência da experiência" (CARNEIRO LEÃO, apud HEIDEGGER, 2006), tratando a obra como iluminadora de possibilidades, ou seja, de verdades, como enfatizado acima, e comprometida com a "fusão de horizontes" históricos (GADAMER, 1997) e sempre no plural. E isto, insisto, não quer dizer arbitrariedade. Mas ao contrário, responsabilidade: pois, agir assim é, sobretudo, tentar deixar falar a obra, mas como a obra não fala por si só, mas por nós, os humanos, nós a escutamos e, devidamente orientados por ela, reordenamos nossos pensamentos e, por conseguinte, nossas interpretações no presente.

Consequentemente, prever que um compositor, ou o que seria mais arriscado, que um conjunto de obras pertencente a uma época específica se esgotaria somente com a consumação de uma modelo interpretativo, por mais responsavelmente que este seja construído, não é apenas ingenuidade. Mas, o que seria pior, presunção em julgar que basta uma pesquisa e uma interpretação para que seja definido, ad infinitum, o valor de uma obra; e que as demais pesquisas e performances envolvendo essa mesma obra ou outras

obras da mesma época, seriam apenas reproduções de um modelo já esgotado; dizendo de outro modo, seria um mero "tecnicismo". E aceitar que 
uma obra se esgote em um único modelo interpretativo, seria negar que as gerações futuras, ou mesmo presentes, não possam, ou sequer tenham o direito de levantar questões a respeito daquilo que fora estudado. No âmbito da reflexão metodológica e, portanto filosófica, seria querer fixar um modelo interpretativo como a única resposta possível ao significado de uma obra. Dizendo de uma forma mais direta, seria tentar fixar um modo de pensamento, portanto um paradigma, e controlar, politicamente é claro, toda uma história que certamente fugirá do nosso controle. Seria, em última análise, um exercício de autoritarismo! Finalmente, seria a negação da diversidade, e consequentemente, da liberdade; e a falta de consciência de que uma interpretação, tal e qual nós humanos, nasce, vive e morre e sempre dentro de uma historicidade que lhe dá validade.

\subsubsection{A modinha e o lundu: uma poética possível}

Após as reflexões anteriores, toda proposta poética efetuada por nós neste segmento, seja uma orientação que vise a uma performance, um concerto ou um registro sonoro, tem obviamente uma validade não definitiva. Mas, seguindo os passos dados até o momento, é evidente que a modinha e lundu da época estudada estão dentro de pressupostos musicais, estilísticos e formais, do que consideramos o estilo clássico: esse é o passado que nos orienta no presente! Portanto, a busca de leveza e simplicidade, o natural da música aos olhos setecentistas, aliadas às sutilezas que enfatizem as conquistas formais discutidas acima, não devem ser ignoradas. Nesse sentido e por mais que cantar empostado possa ser uma atitude não natural, a busca de sutileza, mais do que a exuberância do barroco colossal, é uma dos principais pressupostos: pois, nesses tempos, para comover, basta "percepcionar a música cantada" (VIEIRA DE CARVALHO, 1999, p. 66), mais do que ater-se ao sentido do texto; assim sendo, para que se estabeleça o sentido, "basta sentir" a melodia, o grande veículo expressivo (Ibidem: 94). De qualquer modo, discutiremos abaixo alguns aspectos que consideramos importantes para uma performance, sobretudo por estarem ligados a aspectos estilísticos e não somente a técnicos. 


\subsubsection{Opção vocal}

Se levarmos em consideração que a modinha e lundu do período em foco foram compostos para uma ou duas vozes, geralmente um soprano e um mezzo-soprano, pelo menos nos salões (BARBOSA, 2003, p. 88), e podendo ser interpretada também por cantor, no caso da escrita a solo, ou cantores masculinos (Idem, 2003, p. 86). Porém, apesar de cantores profissionais, como o tenor italiano José Forlivesi, ou o contralto e compositor, também de origem italiana, José Totti (1780-1832), cantarem e a comporem modinhas, há uma preferência pelas vozes femininas (MORAIS, apud BARBOSA, 2003, pp. 8488). O acompanhamento, conforme as publicações, manuscritos e informações de literatos e viajantes era realizado por instrumento de tecla, como o cravo ou fortepiano, este, ainda sem barramento de metal, portanto com sonoridade mais leve; ou instrumento de corda dedilhada, como a guitarra inglesa, viola de arame e, um pouco mais tarde, a guitarra francesa, como ficou conhecido em Portugal o violão de seis cordas simples na virada do setecentos para 0 oitocentos.

Outro fator muito importante, e que não pode ser esquecido, é que a formação da escola musical luso-brasileira durante o século XVIII está absolutamente ligada à tradição italiana: considerando a fundação da Patriarcal, sua ligação inicial com o barroco romano e com Domenico Scarlatti, responsável num primeiro momento; e mais tarde, sobretudo após o terremoto, haverá uma grande influência do barroco napolitano (NERY \& CASTRO, 1999). Nesse sentido, a escola de canto também sofre esta influência, ou seja, vai seguir a tradição italiana.

Na Itália, no início do século XVIII, o grande professor de canto e pedagogo, será Pier Francesco Tosi (1674-1732) e que publica seu tratado em 1723: Opinioni de' cantori antichi e moderni; e Giambatista Mancini (17141800), outro grande cantor e pedagogo, tem seu tratado publicado em 1774: Pensieri e riflessioni pratiche sopra el canto figurato (PACHECO, 2006). Mesmo com uma diferença de mais de cinquenta anos na publicação dos tratados, a grande característica buscada na pedagogia dessa época era "a sonoridade clara e ágil" (PACHECO, 2008, p. 206). 
De todo modo, o ideal iluminista da voz natural não é de todo uma especulação, e sim uma busca do século das luzes, se não consensual, bastante difundida e defendida, inclusive, por um dos filósofos mais renomados da época, Jean-Jacque Rousseau. Mas, o que seria para a época uma voz natural? Aquela com menos potencia dinâmica e, portanto mais leve, ágil e produzida sem esforço? De qualquer forma, uma técnica preocupada com uma maior dimensão sonora e apoiada nos timbres mais escuros, o ideal da "Voix Sombrée" (Idem, 2006: 120), somente se desenvolverá a partir do século XIX. No Brasil, essa tendência se desenvolverá após a década de 1840: "a técnica vocal romântica só começa a se generalizar no Rio de Janeiro a partir de 1844" (Idem, 2009, p. 316). Mesmo quando modinhas e lundus passaram a ser apresentados nos entremezes do Teatro da Rua dos Condes, no Salitre ou no Bairro Alto, o que não tardou muito, e o canto era acompanhado por uma pequena orquestra formada aproximadamente por cinco ou seis instrumentos no máximo e a platéia, como podemos ver em teatros do final do século XVIII, como o de Ouro Preto, não atingia grandes dimensões, a necessidade de uma sonoridade com grandes dimensões não era necessária.

Outro fator não menos importante que devemos ter em mente é que com a vinda da Família Real a partir de 1808, haverá uma intensificação das atividades dos castrati no Rio de Janeiro, que "assim que chegaram (...) se tornaram as grandes atrações" (PACHECO, 208, p.79). Pelo que foi dito acima e levando em consideração a técnica do canto ainda ligada ao ideal setecentista (clareza e agilidade), a sonoridade dos instrumentos (os instrumento de arco com corda de tripa, o fortepiano sem barramento de metal, a sonoridade delicada das cordas dedilhadas), todo o espectro sonoro deveria vibrar em uma dinâmica menos ampla, mesmo que em fins do século XVIII, as dimensões dos teatros e orquestras comecem a aumentar gradativamente. Assim sendo, imaginamos que a voz ideal para as modinhas e lundus tenha as características destacadas acima: clara, leve e ágil, ainda dentro do ideal do século XVIII, tendência que temos defendido neste trabalho. Portanto, as vozes leves e ágeis, sejam de um soprano, mezzo-soprano, ou tenor, parecem ser uma opção consistente; sobretudo para aquelas modinhas nas quais alguns ornamentos rápidos necessitam de clareza. 


\subsubsection{A questão da pronúncia}

Após as reflexões precedentes, entendemos que no canto erudito, persiste o ideal da voz setecentista (clara e ágil) advinda da técnica italiana. Ademais, o grande veículo da época, era a ópera, o padrão a ser seguido, sobretudo pelas classes mais privilegiadas, os nobres burgueses e a classe média emergente. Não obstante, deveria haver um mínimo de adaptação do canto com técnica italiana nas modinhas e lundus efetuados em língua portuguesa, sobretudo se estes veiculavam palavras de origem africana, como por exemplo, "mugangaguerinha" presente no lundu Os me deixas que tu dás (LIMA, 2001, p. 80-84), ou "nhanhá" e "nhonhô" presentes em tantas modinhas e lundus, que exigem do cantor certa nasalização.

Neste aspecto, e concordando com Alberto Pacheco (2008), a pronúncia deveria refletir as diversas camadas sociais que praticavam esses gêneros nessa época: quanto mais ligados às classes privilegiadas e, portanto, com formação musical erudita, a pronúncia deveria se aproximar do italiano (Idem, 285); e o inverso, nas camadas menos favorecidas e com uma formação ligada à tradição popular, a pronúncia deveria carregar características coloquiais (Idem, 286). Não obstante, acreditamos que uma tendência italianizante persistisse, sobretudo nos espetáculos apresentados nos teatros populares (os entremezes), justamente por serem efetuados por profissionais e, portanto, com formação em canto; considerando, inclusive, que num teatro, mesmo de pequenas dimensões, a voz deva ser ampliada e projetada de modo adequado, ou seja, com a técnica da época: "a escola italiana de canto" (PACHECO, 2008, p. 294). Além disso, ainda concordando com Alberto Pacheco (2008), um buliçoso lundu deveria ser interpretado, no mínimo, com sutis diferenças de uma melancólica modinha, se levarmos em consideração o estilo do texto, da melodia e dos afetos envolvidos na caracterização da peça. Mesmo assim, alguns lundus e modinhas que chegaram até nós no presente, exigem do intérprete um mínimo de preparo na "arte do canto", pois, de outro modo, algumas "fiorituras" não serão executadas de modo satisfatório. 


\subsubsection{Opção instrumental}

A maioria dos manuscritos avulsos e códices do século XVIII estão dispostos em uma ou duas linhas dedicadas ao canto e grafados na clave de dó na primeira linha, salvo raras exceções; e para o acompanhamento, a escrita tradicional está disposta em duas claves, sol e fá, ou seja, efetuada para instrumento de tecla: cravo ou fortepiano. Porém há casos em que o documento apresenta somente a clave de fá para o acompanhamento. Neste caso, o teclado ficaria encarregado de efetuar o acompanhamento a guisa de baixo contínuo, ou seja, realizando os acordes; e mesmo que não haja cifras indicadas, um músico minimamente experimentado estaria treinado para tal tarefa.

Há acompanhamentos escritos também para cordas dedilhadas, seja para guitarra inglesa (a futura guitarra portuguesa), viola de arame ou guitarra francesa, mas estes são menos comuns ${ }^{97}$. Mesmo os acompanhamentos dispostos em duas claves (sol e fá) dentro do padrão do cravo ou fortepiano, poderia ser efetuado por uma guitarra seguindo os princípios da realização do baixo contínuo. Informações como estas abundam na literatura de viajantes, como Johann Baptiste von Spix (1781-1826) e Carl Friedrich Philipp von Martius (1794-1868), Johann Moritz Rugendas (1802-1858), Jean-Baptiste Debret (1768-1848); e também em versos de poetas da época, como Tomas Antonio Gonzaga, Cartas Chilenas (2006[1786]) e nos versos do poeta português Tolentino de Almeida (Apud NERY, 2005); como discutimos acima.

Era bastante comum, segundo informações de viajantes e poetas, que os lundus e modinhas fossem acompanhados por dois instrumentos de cordas dedilhadas: um, com o encargo da harmonia; enquanto um segundo improvisava variações ou contracantos de acordo com o estilo e necessidade da performance. Nos entremezes apresentados em teatros, o acompanhamento era efetuado por uma pequena orquestra constituída "por dois violinos, uma violeta e baixo contínuo (realizado por violoncelo ou contrabaixo e cravo ou outro instrumento harmônico." - BARBOSA, 2003, p. 85). Portanto, concluímos que havia bastante liberdade na conformação do

${ }^{97}$ Cf.: ALBUQUERQUE (1996), MORAIS (2000), LIMA (2001), BARBOSA (2003), entre outros. 
acompanhamento deste gênero de música; e acreditamos que no caso de modinhas e lundus executados pelas classes menos favorecidas, as opções instrumentais, podem ser ainda mais inusitadas e neste caso, enriquecidas: pois a escolha dos instrumentos deveria obedecer à lógica das possibilidades reais, utilizando-se instrumentos que nem imaginamos; e não à lógica do ideal: o teclado e a viola de arame.

\subsubsection{Improviso e ornamentação}

O improviso e as ornamentações não escritas foram práticas comuns na história da música ocidental e que vai sendo abandonada paulatinamente. No capítulo referente ao lundu, destacamos seu vínculo com o tema e variação, e como aquele vai se transformando e se adaptando às transformações musicais: no início improvisado e posteriormente, em formas binárias ou ternárias (Cf. capítulo 5). A prática do improviso será incorporada, sobretudo, nos lundus instrumentais ou naqueles supostamente improvisados para a realização da venturosa dança homônima, como destacamos acima, porém, temos informações de que se improvisavam também em modinhas, tanto os versos como a música:

“(..) Os landuns são mais particularmente portugueses do que outros gêneros. Suas guitarras parecem ser feitas para este tipo de música. Para que possam ser bem tocados, é necessário que haja dois instrumentos, uma das quais toca apenas o motivo ou tema, o qual é sempre um bonito e simples arpejo; enquanto a outra improvisa sobre este os mais deleitáveis melodias. Nestas ocasiões, dá-se a imaginação a maior e mais rica liberdade possível e ocasionalmente pode ser que sejam acompanhadas por voz; nestes casos é usual que sejam também improvisadas" (A.P.D.G, 1826, pp. 220-221).

E mais abaixo:

“(...) É costumeiro que, numa modinha improvisada, estritamente falando, tanto as palavras quanto a música possam começar com um motivo, sobre o qual todo o restante deva fazer referência. (Idem, p. 221)

Neste aspecto, o mesmo princípio discutido sobre os lundus improvisados pode ser aplicado também a modinhas, atestando que a tradição do improviso, ou tema e variação, já adaptado à conjuntura da modinha e do lundu, achavam-se bastante vivo na cultura luso-brasileira no início do século XIX, época em que A.P.D.G. presenciou estes acontecidos. Com relação aos 
improvisos e ornamentações efetuados em modinhas e lundus escritos, também deveriam ser muito comuns, mas certamente deveriam ficar a cargo de cantores mais experimentados.

Dentre os ornamentos mais comuns, destacamos a apojatura, o trinado, mordente, o grupeto, notas de passagem, portamento (slide), picado (staccato) e insistimos que quanto maior o grau de preparo do intérprete de modinhas e lundus, mais podiam ser sofisticados. (BARBOSA, 2003, p. 44). Estes poderiam ser escritos ou efetuados de improviso e deveriam ser adaptados ao estilo vigente para os gêneros e a época em questão. De qualquer modo, como este trabalho não tem a intenção de constituir-se em um manual de performance, e isso seria uma contradição à nossa proposta, não vemos a necessidade de uma descrição mais pormenorizada. Porém, na introdução efetuada pelo musicólogo Manuel Morais para livro de Domingos Caldas Barbosa (2003), Muzica escolhida da Viola de Lereno, também no livro Castrati e outros virtuoses de Alberto Pacheco (2009), encontramos excelentes exemplos de como esta prática pode ser sesenvolida.

Evidentemente, que nos tratados que sobejam nos sites especializados na internet, poderemos encontrar apoio para um estudo mais aprofundado visando esta prática; porém, insistimos, uma abordagem desse tipo fugiria ao escopo deste trabalho. O que realmente nos interessa frisar, é que na prática da modinha e do lundu, a tradição do improviso andava pari passu com uma tradição que estava presente não só nas óperas, e nos salões sofisticados da nobreza e da burguesia onde os castrati, sobretudo na época em que a corte habitou o Rio de Janeiro, reinavam soberanos; ou nos saraus, onde José Maurício, Marcos Portugal e Sigismun von Neukomm, talvez com alguma rivalidade, ombrearam em improvisos ao teclado. Mas também, seguramente, essa prática perpetuou-se nas modinhas e lundus que, às vezes juntos, às vezes separados, continuaram suas sendas. 


\section{Conclusão}

O texto esboçado teve como objetivo precípuo uma compreensão da modinha e do lundu como gêneros musicais elaborados após a segunda metade do século XVIII e ligados às transformações sócio- culturais ocorridas no panorama luso-brasileiro; e como absorveu as características estilísticas e formais do que viria a ser conhecido como estilo clássico, tanto poético quanto musical. Foi por esse motivo que buscamos logo num primeiro momento, definir o período de surgimento, procurando efetuar um paralelo entre esses gêneros e as tendências estéticas hegemônicas atuantes na sociedade lusobrasileira; e como participaram dos modelos praticados no mundo europeu. Destaquemos ainda como a cultura popular da época participa na formação do lundu, tanto em sua forma dançada quanto cantada; e entender como os gêneros em questão - a modinha e o lundu - participam não só da sociedade luso-brasileira da época, mas também como essas manifestações se inserem no panorama estético europeu no século XVIII, absorvendo as tendências formais clássicas do século das luzes, que denominamos "sistema mundo cultural"; e dialogando, inclusive, com a sociedade deste lado do Atlântico.

Por tais razões buscamos definir a época de surgimento da modinha e do lundu: último quartel do século XVIII. Evidentemente a canção de amor participa da história da música ocidental desde os tempos de antanho, porém, o termo modinha somente surgirá como denominação da canção de amor por excelência a partir do último quartel do século XVIII. Também o lundu, primeiro para caracterizar um tipo de dança e posteriormente a canção de nome homônimo, surge nestes últimos anos dos setecentos, época considerada como auge do estilo clássico. Seguramente não comungamos da interpretação de que os estilos se sucedem em bloco, como se as mudanças fossem homogêneas e globais. Ao contrário, entendemos que as mudanças não são lineares e dependem de fatores muito complexos nem sempre fáceis de precisar (JENKINS, 2007).

Porém, aos estudarmos a sociedade luso-brasileira deste período, vimos o quanto ela será forjada pelas tendências ilustradas atuantes, não somente em sentido político-cultural, mas também em sentido social: já num primeiro momento, a reforma da educação empreendida pelo Marques de Pombal, visou 
à criação de uma escola com tendências seculares, calcada não só no cientificismo da época, mas também na leitura dos clássicos, mitigando, portanto conteúdos de cunho religioso e, supostamente, místico da formação jesuítica (NETO, 2008, p. 236; SILVA, 2006). Por outro lado, todo um aparato de entretenimento será paulatinamente construído em Lisboa, como teatro dedicado aos espetáculos de ópera, tanto séria quanto bufa, que servirão de escola para um modelo de conduta vinculada ao modelo civilizador ilustrado, que será implantado em ambos os lados da civilização lusitana, de além e de aquém-mar (VIEIRA DE CARVALHO, 1993).

Vimos também como a canção de amor desse período, que será denominada modinha, absorverá tanto poética quanto musicalmente esta cultura ilustrada e que se comportará como um "verdadeiro" modelo de conduta absorvido num primeiro instante pela burguesia e pela classe média e logo em seguida por todas as classes menos favorecidas antes mesmo da virada para 0 século XIX. É neste aspecto que a ópera e a música dos salões, são consideradas complementares: uma que vigia a vida pública; e outra no círculo social privado. E para a mulher dessa época, cantar o amor nos salões ou ir à ópera, era participar de uma emancipação social que estava sendo preparada, também via modelos comunicativos musicais como defendeu Machado Neto (2008).

Ora, o surgimento de publicações dedicadas à prática da canção doméstica, como o Jornal de modinhas (1792-1796) e o Jornal de modinhas novas para as senhoras (1801); os manuais que ensinam a "tanger" a guitarra, como Nova arte de viola que ensina a tocalla com fundamento sem mestre, de Manoel da Paixão Ribeiro (1789); o Estudo de guitarra, em que se expõe o meio mais fácil para aprender a tocar este instrumento, de Antonio da Silva Leite (1796); as coleções dedicadas a particulares como Modinhas do Brasil (LIMA, 2001) efetuada "para o uso da $D^{a}$. Exm ${ }^{a}$. Snr ${ }^{a}$. D. Jozefa Vitoria Barreto Moniz e D ${ }^{\text {a }}$. Ex ${ }^{\text {a. }}$ Sr ${ }^{a}$. D ${ }^{\text {a }}$. Antonia do Carmo Moniz" (BEHAGUE, 1968) e Muzica escolhida da viola de Lereno, dedicada "Para o uso da $\|^{\mathrm{ma}}$ e Ex ${ }^{\mathrm{ma}} \mathrm{Sr}^{\mathrm{a}}$ D. Marianna de Souza Coitinho" (BARBOSA, 2003); ou ainda modinhas avulsas, como Duettini, Cavatina, e Canzontina Portoghese composta pelo contralto Giuseppe Totti (17..-1832), a [Colectânea] de Modinhas efetuada por Domingos Schiopetta (1788-1835) disponíveis na página a Biblioteca Nacional 
de Lisboa em Portugal, são alguns exemplos de uma produção musical voltada para o uso doméstico na qual a modinha e o lundu se inserem.

Como pudemos constatar essa nova onda de canções domésticas, além de peças instrumentais dedicadas aos amadores, não será um privilégio somente de Portugal; mas toda a Europa participa deste vagalhão. Nesse sentido, a modinha e o lundu estavam inseridos dentro das mudanças globais empreendidas pelo pensamento iluminista e acompanharam as tendências internacionais da cultura ilustrada, voltada para uma cultura de entretenimento, onde se poderia exercitar a sensibilidade, seja no conforto do lar, nas reuniões árcades, nas óperas efetuadas para as diversas camadas sociais ou nos entremezes dos teatros mais populares.

Não só como um modelo social, mas também em sentido poéticomusical, como vimos nos capítulos 4 e 5, a modinha e o lundu participam das tendências classicizantes que dominam a musicalidade européia. A poesia que dará suporte às modinhas será aquela efetuada pelos poetas árcades, adeptos de um formalismo simétrico, com verso direto, sem inversões e figuras de linguagens e ritmo simples; tematização do amor ideal, a presença do pastor em comunhão com a natureza, tendo como pano de fundo as paisagens bucólicas, também se inserem nesta tendência. No que tange à questão musical, salvo algumas exceções, penderá para as formas simétricas, binárias ou ternárias, com ou sem refrão, construídas a partir da frase articulada e periódica, a pedra de toque do estilo clássico. Nesse sentido, a opção pelos versos diretos, pela poesia sem rodeios, pela melodia acompanhada em detrimento do contraponto tonal barroco, a modinha estará completamente sintonizada com a estética da sensibilidade e do sentimento que irá dominar o século das luzes, essa tentativa de união entre razão, sentimento e natureza, o grande modelo neoclássico do século XVIII.

Porém, os textos poéticos que darão base aos lundus, trazem as marcas da cultura popular, mesmo que adaptadas à poesia árcade, formal e simétrica. Assim, ao serem utilizados vocábulos do mundo afro-brasileiro, tais como "quingombó", "angu", e da tradição indígena da época, tais como "xarapin", "cuia", presentes no poema Lundum de cantigas vagas citado no texto $O$ canto e a lira desta tese, fugindo da tradição clássica e trazendo para o mundo da elite tendências populares, efetua-se o que Mikhail Bakhtin denominou de 
"carnavalização", ou seja, a "fusão entre o 'erudito' e o 'popular', o 'oficial' e o 'não oficial' (RENÓ, 1999, p.24).

De qualquer modo, e mesmo comungando com a interpretação de que o modelo cultural de fins do século XVIII obedecerá a tendências hegemonicamente iluministas, instaurando pouco a pouco formas de sociabilidade seculares, potencializando formas de fruição racionalizada, a adaptação desse modus vivendi deste lado do Atlântico não controlaria, ao nosso ver, totalmente a conduta da sociedade da época. $E$ é nesse sentido que entendemos o lundu em sua dupla forma de manifestação, uma dançada e outra cantada, e como discutimos no corpo desse trabalho, sobretudo no texto O enigma do lundu: se por um lado, a coreografia do lundu dançado na corte será estilizada, afastando-se da "sensualidade", ou dos movimentos "indecentes" que o caracterizaram num primeiro momento e aproximando-o das danças cortesãs do século XVIII, a ponto de substituir a umbigada pela troca do lenço, como relatou A.P.D.G. (1826, p. 287); por outro lado, como relata o mesmo autor, "quando é dançado pela ralé está longe de ser gracioso e decente" (Ibidem, p. 290), o que em nossa interpretação quer dizer que distante do controle social da elite educada, permanecia lascivo e sensual, ou seja, não totalmente domesticado, mas híbrido (CANCLINI, 2008), mestiço (GRUZINSKI, 2001). Mais à frente, o mesmo A.P.D.G., relata que "tanto negros como portugueses teriam alcançado, eles mesmos, um estado de frenesi e convulsão" (Ob, cit. 1826, 290), atestando ainda mais a distância de um controle racionalizado na manifestação dessa dança, longe dos círculos mais "civilizados".

No que tange à questão musical, o lundu, de fato, toma para si formas poético-musicais advindas do estilo clássico; porém, ao adaptar a frase articulada às tendências contramétricas, ou 0 que denominamos tradicionalmente de síncope, o lundu imprimiu na musicalidade deste lado do Atlântico, uma das características consideradas marcantes da manifestação da cultura negra não só na América Portuguesa, mas também na América Espanhola. Nesse sentido, com base nas teorias de contrametricidade e cometricidade e na elaboração do que se denominou ciclos rítmicos (Cf. MUKUNA, 2006; SANDRONI, 2001), defendemos uma tendência formalística na música tradicional negra, compatíveis com a estruturação da frase na 
música ocidental; defendemos também, que uma adaptação entre os dois modos de estruturação musical - a frase musical e o ciclo rítmico - seria mais eficaz quando efetuada em frases simétricas, com número fixo de pulsos, facilitando a adaptação. Assim, a simetria formal presente na frase clássica facilitou a adaptação de uma estruturação simétrica presente na cultura negra, o ciclo rítmico. Ora, se a "inoculação" do modelo civilizador ocidental foi grande, como defende Machado Neto, não foi homogênea. Foi, portanto, nesse sentido que entendemos o uso da frase sincopada (contramétrica) e da incorporação de vocábulos do mundo popular na poesia árcade: num dado momento deixam de constituir mero detalhe para converter-se no reconhecimento de uma alteridade; logo, deixam de ser ornamento, e passam a ser monumento, identificando um novo gênero: o lundu.

Quanto à história da modinha e do lundu, tentamos compreender como adentram a historiografia no início do século XX, participando das discussões relacionadas com a construção da identidade nacional ligadas ainda a tendências nacionalistas, lideradas, sobretudo, pelos ideais modernistas, encabeçado por Mário de Andrade, com base em dois textos publicados nos dois últimos anos da década de 1930, o Ensaio sobre na música brasileira, publicado em 1928 e Modinhas Imperiais, publicado em 1930. Verificamos como esses textos ainda estão fundamentados na concepção de meio e raça provindos do século XIX e calcados nos escritos de Silvio Romero (VOLPE, 2010). Seguindo essa linha de pensamento, o Brasil, mesmo na época em que Mário de Andrade escreveu, ainda estava por ser "inventado". Vigia em seus escritos uma espécie de projeto "futurístico"; é nesse sentido que se viabiliza a afirmação "Os artistas duma raça indecisa se tornaram indecisos que nem ela" (ANDRADE, 1962[1928]). A afirmação de uma cultura nacional segundo Mário de Andrade, portanto, somente poderia provir da superação das indecisões que ocorreriam com a incorporação da "alma do povo", ou seja, o folclore e a produção artística (a música erudita). E nesse sentido, ainda um projeto elitista e determinista, nos moldes do pensamento novecentista.

Outra corrente da historiografia sobre a modinha e o lundu, não mais estará preocupada com o folclore como arcabouço na construção da identidade; mas irá aceitar a modinha e lundu de fins do século XVIII como autênticos representantes de uma identidade brasileira, como afirmam Mozart 
de Araujo (2003), Bruno Kiefer (1977) e José Ramos Tinhorão (1991, 1998 e 2004), identificando, inclusive, a origem da modinha e do lundu com a figura de Domingos Caldas Barbosa. Portanto, buscariam no passado os marcos fundadores da identidade musical brasileira, ainda com base, evidentemente, no mito fundacional. Nesse sentido, propusemos um entendimento da complexidade social, após a segunda metade do século XVIII, suas conseqüências na sociedade luso-brasileira da época relacionadas ao surgimento da modinha e do lundu e seus desdobramentos na formação da cultura musical brasileira; mas sem preocupações nacionalistas. Encaramos a historiografia como uma opção interpretativa comprometida com metodologias e ideologias, nunca como uma descoberta no sentido tradicional e dentro de uma perspectiva linear, mas sim como uma opção interpretativa, construtiva.

De qualquer modo, apesar de nossa concordância com os escritos de Mário Vieira de Carvalho e Diósnio Machado Neto de que a sociedade lusobrasileira pós-pombalina passa por uma reformulação de cunho iluminista e que os modelos musicais estarão inseridos dentro desses pressupostos, ressaltamos que a tese de Machado Neto sobre o "embranquecimento" (2008, p. 230), não tem alcance absoluto, sobretudo se levarmos em conta que o lundu já nasce comprometido com a cultura popular, e não apenas com os aspectos civilizados da cultura burguesa ilustrada. E continua sua senda, negociando sua liberdade e influenciando a cultura letrada, numa espécie de "liberdade relativa", como define Alencastro (2001) o mundo do mulato ou mestiço livre na colônia brasileira. Nesse sentido, o lundu não seria somente "afro"; nem mesmo somente "luso": mas constituir-se-ia num gênero híbrido, articulando elementos pertencentes a camadas sociais diversas, incorporando e comportando características da cultura popular e da elite, já em sua forma inicial, tanto dançada quanto cantada. $E$ isso, a nosso ver, não seria somente $o$ resultado do descontrole lusitano e, nesse sentido, um desvio dos modelos civilizadores da época; mas também a manifestação da resistência de atores sociais pertencentes às camadas menos favorecidas, como teorizado por Manuel Castells (1999, p. 24), uma possível identidade de resistência, como discutimos no capítulo 3 .

Também nesse sentido, a postura do pensamento de cunho nacionalista dos intelectuais modernistas, sobretudo os seguidores de Mário de Andrade, e 
sua insistência no modelo de pensamento ainda romeriano, colocando o folclore no centro da construção de uma possível nacionalidade futurística, como destacado por Maria Alice Volpe em seu texto Traços romerianos no mapa musical do Brasil (2010), merece ressalva; pois, a música produzida nos centros urbanos, embora participe de esquemas "acentuadamente comercializados", não anula, por principio, "as tradições populares" (DUPRAT, 2001, p. 2), mas constituem outras construções identitárias. Portanto, como destaca Regis Duprat ao abordar a questão da construção de uma possível identidade na musica brasileira, superando completamente o pensamento nacionalista ainda calcado num projeto unidirecional e o historicismo tradicional, sintetiza:

"Trata-se de aceitar o jogo das ideologias, que geram diferenças de pontos de vista. O jogo democrático é o jogo do diálogo, livre, amplo e irrestrito. Se estivermos convictos de que na base de uma definição qualquer do caráter brasileiro estará sempre uma ideologia inspiradora e geradora dessa definição. Se nos convencermos de que, como sugere Vattimo (1989, 39. 38-48) a interpretação, ou melhor, a hermenêutica, não é apenas uma fase provisória de diálogo e debate que possa nos conduzir ao conhecimento ou formulação do entendimento acabado e definitivo de algo, mas sim a própria permanência do diálogo, do debate. A Hermenêutica não como Teoria do Diálogo, mas como o próprio diálogo. Vamos compreender melhor a História e a correlação entre identidade e diferença. $E$, no nosso caso, o que é música brasileira para cada um de nós e para o outro, já que as diferenças seriam justamente o pólo a dar sentido às eventuais identidades" (DUPRAT, 2001. P. 9-10).

A performance relacionada à modinha e ao lundu também nos serviu de base para discutirmos o que denominamos "paradigmas interpretativos". A partir de registros musicais efetuados desde o final da década de 1950, procuramos acompanhar como tais registros se adequaram às concepções estéticas, vinculadas, portanto, a determinadas correntes de pensamento. Os primeiros registros ainda refletem tendências romantizadas que perduram até à década de 1980, pelo menos. Ao lado dessa tendência, houve a incorporação de elementos oriundos da música popular, tanto folclórica quanto a produzida nos grandes centros urbanos. A partir do final da década de 1980, ocorre uma incorporação gradativa do pensamento ligado à performance histórica, numa busca de distanciamento dos modelos ainda calcados na tradição romântica. 
Apoiado no conceito de paradigma de Thomas Khun (2009), entendido como o modo de uma comunidade científica compartilhar um método, e também na aplicação desta concepção ao mundo da arte, efetuada por Gianni Vattimo em seu texto A estrutura das revoluções artísticas (VATTIMO, 1999), buscamos entender, como essas interpretações se comportam como modelos compartilhados por comunidades, sobretudo a corrente que se intitula na atualidade de "performance historicamente informada". Por tal razão propusemos a expressão "paradigmas interpretativos"; e, sobretudo, como esta corrente se comporta mais próxima de uma prática ideológica, ou seja, uma busca constante pelo domínio político de toda uma área correspondente; e de modo algum dentro dos modelos da historiografia atual, hoje, amplamente consciente das diferenças e diversidades no que tange a construção da histórica. A corrente auto-cognominada "performance historicamente informada", insistimos, continua nesse sentido atuando dentro de modelo interpretativo vinculado às concepções positivistas e com base numa história factual, calcada ainda no mito do documento como retrato fiel do passado, o que os historiadores denominaram "realismo ingênuo" (SAMUEL, apud, JENKINS, 2007, p. 19); e não encarando o documento também como uma outra construção, como uma outra interpretação.

Em síntese, buscamos uma compreensão da modinha e do lundu, não só como gêneros musicais, mas também na sua ligação com as mudanças sócio-culturais ocorridas, sobretudo, a partir da segunda metade do século XVIII; como se articularam, nesses dois gêneros musicais, não só tendências vinculadas ao estilo clássico vigente na época, mas também como se comportaram as tendências advindas da cultura popular da época que transpiravam tendências internacionais. Também buscamos compreender como esses gêneros participaram, e têm participado da historiografia ao longo do século $X X$ e do mundo do concerto, da performance, que não está de modo algum imune aos modelos históricos epocais. Em suma, refletir hoje sobre a modinha e o lundu, esses dois clássicos de nossa expressão musical, é acompanhar a trajetória de dois gêneros que por mais de dois séculos vêm alimentando debates, publicações e registros musicais. 


\section{Referências bibliográficas}

\subsection{Bibliografia}

ALBUQUERQUE, João M. Jornal de modinhas, ano I. Lisboa: Inst. Da Biblioteca Nacional e do Livro, 1996.

ALENCASTRO, Luiz F. de A pena e o pincel. In STRAUMANN, Patrick. Rio de Janeiro cidade mestiça: nascimento da imagem de uma nação. São Paulo: Cia. das Letras, 2001. Pp. 133-164.

ALENCASTRO, Luiz F. de. 0 trato dos viventes: formação do Brasil no Atlântico Sul. São Paulo: Cia. das Letras, 2000.

ALMEIDA, Renato. Compêndio de História da música brasileira. $2^{2}$ Ed. Rio de Janeiro: F. Briguiet \& Cia., 1958.

ANDERSON, Benedict. Comunidades imaginadas: reflexões sobre a origem e a expansão do nacionalismo. Lisboa: Edições 70, 2005.

ANDRADE, Ayres. Francisco Manuel da Silva e seu tempo. Rio de Janeiro: GG, 1967. 2 vol.

ANDRADE, Mário de. Ensaio sobre a música brasileira. São Paulo: Livraria Martins Editora, 1962(1928).

ANDRADE, Mário de. 0 banquete. Belo Horizonte: Editora Itatiaia, 2004[194345].

ANDRADE, Mário de. Paulicéia desvairada. São Paulo: Círculo do Livro S/A, 1971.

ANDRADE. Mário de. Aspectos da música brasileira. Belo Horizonte - Rio de Janeiro: Villa Rica, 1991[1936].

ANDRADE. Mário de. Modinhas Imperiais. Belo Horizonte: Itatiaia, 1980[1930].

ARAUJO, Mozart de. A modinha e o lundu no século XVIII. São Paulo: Ricordi Brasileira, 1963.

AUGUSTIN, Kristina. Um olhar sobre a música antiga: 50 anos de história no Brasil. Rio de Janeiro: Augustin, 1999.

BARBOSA, Domingos Caldas. Muzica escolhida da Viola de Lereno (1799). Portugal: Estar, 2003.

BARBOSA, Domingos Caldas. Viola de Lereno. Vol. I e II. Rio de Janeiro: Civilização Brasileira; Brasília: INL, 1980.

BARREIRO, José C. Imaginário e viajantes no Brasil do século XIX: cultura e cotidiano, tradição e resistência. São Paulo: Editora Uniso, 2002. 
BÉHAGUE, Gerard. Biblioteca da Ajuda (Lisbon) Mss. 1595 / 1596: Two EighteenthCentury Anonymous Collections of Modinhas. In Anuario, Vol. 4, (1968), pp. 44-81.

BISPO, A. A. Um manuscrito de modinhas da Biblioteca Estatal Bávara de Munique. In Boletim da Sociedade Brasileira de Musicologia. Rio de Janeiro: s/d.

BLUME, Friedrich. Classic and romantic music. New York: Norton: 1970.

BOSI, Alfredo. História concisa da literatura brasileira. São Paulo: Editora Cultrix, 1994.

BROWN, Clive. Classical and Romantic performance practice, 1750-1900. New York: Oxford University Press, 1999.

BUCHNES, Alexandre. Encyclopédie des instruments de musique. França: Gründ, s/d.

BUDASZ, Rogério. Música no tempo de Gregório de Matos. Curitiba: DeArte/UFPR, 2004.

BUKOFZER, Manfred F. La música en la época barroca: de Monteverdi a Bach. Madrid: Alianza Música, 2002.

BURKE, Peter (Org.). A escrita da história: novas perspectivas. São Paulo: UNESP, 1992.

BURKE, Peter. Hibridismo cultural. São Leopoldo - SR: UNISINOS, 2003.

BURKE, Peter. O que é história cultural? 2ª . Ed. Rio de Janeiro: Jorge Zahar Editor. 2008.

CACCINI, Giulio. Le nuove musiche. Madison: A-R Editions, Inc., 1982.

CACCINI, Giulio. Nuove musiche e nuova maniera di scrivirla (1614). Madison: A-R Editions, Inc., 1978.

CAMARGO, Guilherme de. Modinhas \& lundus do Brasil. In $\mathbf{O}$ amor brazileiro: modinhas \& lundus do Brasil (CD). França: K617; São Paulo: Cia do Gato: 2004.

CANCLINI. Nestor. G. Culturas híbridas. 4ª . Ed. São Paulo: Edusp, 2008.

CANDÉ, Roland. História universal da música. São Paulo: Martins Fontes, 1994.

CÂNDIDO, Antônio. Formação da literatura brasileira. São Paulo: Martins Fontes, 1964.

CARDOSO, André. A música na Corte de d. João VI: 1808-1821. São Paulo: Martins, 2008.

CASTANHA, Paulo. Gabriel Fernandes da Trindade. São Paulo: Paulus, 1995. 
CASTANHA, Paulo. Herança ibérica e africana no lundu brasileiro dos séculos XVIII e XIX. In: TELLO, A. (Editor). La danza em la época Colonial Iberoamericana. Bolívia: Associación Pró Arte e Cultura: 2006.

CASTELLS, MANUEL. 0 poder da identidade. Vol. 2; 5⿳亠丷. Ed. Rio de Janeiro: Paz e Terra, 1999.

Cf. SANZ, Gaspar. Instrucción de música sobre la guitarra espátula. Genebra, 1976 [1697].

CHAUI, Marilena. Brasil: mito fundador e sociedade autoritária. São Paulo: Editora Fundação Perseu Abramo, 2000.

CIMAROSA, Domenico. Sei canzonette italiane, coll'accompagmamento di Chitarra. Firenze, S.P.E.S., 1985.

CONTIER, Arnaldo. D. Música e ideologia no Brasil. 2ª Ed. São Paulo: Novas Metas, 1985.

COOPER, Grosvenor \& MEYER, Leonard. The rhythmic structure of music. Chicago: University of Chicago Press, 1960.

CRUZ, Gabriela. Nota introdutória. In CÂMARA, Joaquim Manoel \& NEUKOMM, Sigismund. 20 modinhas portuguesas. Portugal: Musicoteca, 2000.

CUNHA, Celso. Nova gramática do português contemporâneo. $3^{\text {a }}$ ed. Rio de Janeiro: Lexicon Informática, 2007.

DAHLHAUS, Carl. Estética Musical. Lisboa: Edições 70, 2003.

DEBRET, Jean Baptiste. Viagem pitoresca e histórica ao Brasil. São Paulo: Martins; Editora da Universidade e São Paulo, 1972. 2 vol.

DIDIER, Pablo \& COSTA Maria de F. Rugendas e o Brasil. São Paulo: Editora Capivara Ltda, 2002.

DODERER, Gerard. Modinhas luso-brasileiras. Lisboa: Fundação Calouste Gulbenkian, 1984

DOLMETSCH, Arnold. The interpretation of the music of the 17th and 18th centuries. New York: Dover Publications, Inc., 2005[1915].

DOSSE, François. História em migalhas: dos Annales à nova História. São Paulo: Edusc, 2003.

DUPRAT, Régis. Música brasileira. In Revista Oficina da Inconfidente. Ouro Preto, MG, ano 2, n. 1, 2001, pp. 233-238.

DUPRAT, Régis. Música e mito: barroco no período colonial. In ARTEunesp, São Paulo, vol. 6, pp. 61-67, 1990.

DUPRAT, Régis. Uma cultura (musical) transplantada. In Rio de Janeiro 18421920: Uma trilha musical (CD). São Paulo: IMS, 1999. 
EAGLETON , Terry. A ideologia da estética. Rio de Janeiro: Jorge Zahar Editor, 1993.

EAGLETON , Terry. Ideologia. São Paulo: Unesp / Boitempo, 1997.

EFEGÊ, Jota. Maxixe, a dança excomungada. Rio de Janeiro: Conquista, 1974.

FAGERLANDE, Marcelo. Joaquim Manoel, improvisador de modinhas. Revista semestral da academia brasileira de música, n. 27, p. 8-10, 2008.

FAUSTINO, Mário. De Anchieta aos concretos. São Paulo: Cia. das Letras, 2003.

FOUCAULT, Michel. Microfísica do poder. Rio de Janeiro: Edições Graal, 1979.

FUBINI, Enrico. Estetica della musica. Bologna: II Mulino, 1995.

FUBINI, Enrico. L'estetica musicale dal settecento a oggi. Torino: Piccola Biblioteca Einaudi, 1987.

GADAMER, H. G. Verdade e método. 6ª . Ed. Vol I. Rio de Janeiro: Editora Vozes, 1979.

GALVÃO, Augusto P. A modinha norte-rio-grandense. Recife: Editora Massagana, 2000.

GIULINI, Mauro. Cavatine e Romanze, per voce e chitarra. Firenze: S.P.E.S.: 1983.

GIULINI, Mauro. Sechs Lieder, op. 89. Tecla Edition: London, 1976.

GIULINI, Mauro. Sei Ariette, for voice and guitar or piano. London: Tecla Editions, 1987.

GIULINI, Mauro. Sei Cavatine per voce e chitarra. Litolff, 1984.

GOLDSTEIN, Norma. Versos, sons, ritmos. São Paulo: Editora Ática, 1990.

GONZAGA, Tomás A. Cartas Chilenas. São Paulo: Cia. das Letras, 2006[1786].

GONZAGA, Tomás A. Marília de Dirceu. São Paulo: Publifolha, 1997[1792].

GROUT, D. J. A history of Western music $7^{\text {th }}$ ed. New York: W.W. Norton \& Company, 2006.

GRUZINSKI, Serge. As novas imagens da América. In STRAUMANN, Patrick. Rio de Janeiro cidade mestiça: nascimento da imagem de uma nação. São Paulo: Cia. das Letras, 2001. Pp. 165-191.

GRUZINSKI, Serge. O pensamento mestiço. São Paulo: Companhia das Letras, 2001. 
HAYDN, Joseph. Lieder, para una voz con acompañamiento de piano. Buenos Aires: Ricordi Americana, 1960.

HEIDEGGER, Martin. A origem da obra de arte. Lisboa: Ed. 70, 1992.

HEIDEGGER, Martin. Ensaios e conferências. Petrópolis: Vozes; Bragança Paulista: Universidade São Francisco, 2006.

HEITOR, Luiz. 150 anos de música no Brasil. Rio de Janeiro: Livraria José Olympio Editora, 1956.

HEITOR, Luiz. Música e músicos do Brasil. Rio de Janeiro: Livraria e Editora da Casa do Estudante, 1950.

HOBSBAWM, Eric J. Nações e nacionalismos desde 1780. Rio de Janeiro: paz e Terra, 1990.

HOLANDA, SERGIO B. Raízes do Brasil. São Paulo: Cia. das Letras, 2006.

JEFFERY, Brian. Introduction. In Seguidillas, for voice and guitar or piano. London: Tecla Editions, 1976.

JEFFERY, Brian. Introduction. In The complete Italian arietts, Italian duets, ans the three canons. London: Tecla Editions, 2002.

JENKINS, Keith. A história repensada. 3ª Ed. São Paulo: Contexto, 2007.

JIMENEZ, M. O que é estética? São Leopoldo - RS: Ed. UNISINOS, 1999.

KERMAN, J. Musicologia. São Paulo: Martins Fontes, 1987.

KIEFER, Bruno. A modinha e o lundu: duas raízes da música popular brasileira. Porto Alegre: Editora Movimento, 1977.

KIEFER, Bruno. Música e dança popular: sua influência na música erudita. Porto Alegre: Editora Movimento, 1979.

KUHN, Thomas S. A estrutura das revoluções científicas. 9aㅡ Ed. São Paulo: Perspectiva, 2009.

LEITE, Antonio da S. Estudo de Guitarra. Porto: Officina Typografica de Antonio Alvarez Ribeiro, 1796.

LIMA, Edilson V. As modinhas do Brasil. São Paulo: Edusp, 2001.

LIMA, Edilson V. Do lundu-dança ao lundu-canção. In: TELLO, Aurélio (Editor). La danza em la época Colonial lberoamericana. Bolívia: Associación Pró Arte e Cultura: 2006.

MACHADO, Cacá. O enigma do homem célebre: ambição e vocação de Ernesto Nazareth. São Paulo: Instituto Moreira Salles, 2007.

MARÍN, José. 51 tonos para voz y guitara. Ohio, Columbus, 1997.

MATEIS, Nicola. The false consonances of music (1682).Great Britain: Chanterelle, 1980. 
MELLO, Guilherme de. A música no Brasil. 2ª Ed. Rio de Janeiro: Imprensa Nacional, 1947.

MICHELS, Urlich. Atlas de música, vol. I. Espanha: Alinza Editorial, 2002.

MILÁN, Luis. El maestro (1536). Vol, I e II. Budapest: Könemann Musik, 2000.

MOISÉS, Massaud. A literatura portuguesa. $33^{a}$ ed. São Paulo: Editora Cultrix, 2005.

MONTEIRO, Maurício. A construção do gosto: música e sociedade na corte do Rio de Janeiro 1808-1821. São Paulo: Ateliê Editora, 2008.

MORAIS, Manuel. Modinhas, lundus e cançonetas: com acompanhamento de viola e guitarra inglesa. Prefácio de Rui Vieira Nery. Lisboa: Imprensa Nacional-Casa da Moeda, 2000.

MOZART, A. A modinha e o lundu no século XVIII. São Paulo: Ricordi, 1963.

MOZART, Wolfgang. A. Twenty-one songs, England: Oxford University Press, 1992.

MUKUNA, K. Contribuição Bantu na música popular brasileira: perspectivas etnomusicológicas. São Paulo: Terceira Margem, 2006.

NAWROT, P. Archivo musical de Moxos - Antologia. 4 volumes. Bolívia: Fondo Editorial APAC, 2004.

NAWROT, P. Sonatas barrocas. 5 volumes. Bolívia: Editorial Verbo Divino, 2006.

NERY, Rui V. e CASTRO, Paulo F. História da música. Lisboa: Imprensa Nacional - Casa da Moeda, 1999.

NERY, Rui Vieira. Para uma história do fado. Lisboa: Público, 2005.

NETO, Diósnio M. Administrando a festa: música e iluminismo no Brasil colonial. 2008. 470 f. Tese (Doutorado em musicologia) Universidade de São Paulo: São Paulo, 2008.

NOVAIS. F. A. Aproximações: estudos de histórica e historiografia. São Paulo: Cosac Naify, 2005.

ORTIZ, Diego. Tratado de glosas sobre clausulas y otros generos de puntos en la musica de violines. Germany: Bärenheiter, 1967.

ORTIZ, Renato. Cultura brasileira e identidade nacional. 4a . Ed. São Paulo: Brasiliense, 2004.

ORTIZ, Renato. Românticos e folcloristas. São Paulo: Relógio d’Água, 1992.

PACHECO, Alberto J. V. Castrati e outros virtuoses: a prática vocal carioca sob a influência da corte de d. João VI. São Paulo: Annablume - Fapesp, 2008.

PACHECO, Alberto J. V. O canto antigo italiano: uma análise comparativa dos tratados de canto de Píer Tosi, Giambattista Mancini e Manuel P. R. Garcia. São Paulo: Annablume - Fapesp, 2006. 
PAIVA, Eduardo F. \& Anastásia, Carla M. O trabalho mestiço: maneiras de pensar e formas de viver, séculos XVI a XIX. São Paulo: Annablume, 2002.

PEREIRA, Esther. Lundus e modinhas do século XIX. Rio de Janeiro: Tempo Brasileiro; Bahia: Fundação Cultural do Estado da Bahia, 1981.

REIS, José C. As identidades do Brasil: de Varnhagen a FHC. 3ª . Ed. Rio de Janeiro: FGV, 2000.

RENÓ, Adriana C. Violando as regras: uma (re) leitura de Domingos Caldas Barbosa. São Paulo: Arte \& Ciência, 1999.

RIBEIRO, Gladys S. A liberdade em construção: identidade nacional e conflitos antilusitanos no Primeiro Reinado. Rio de Janeiro: Relume Dumará, 2002.

RIBEIRO, Manoel da P. Nova arte de viola. Coimbra: Real Officina da Universidade, 1789.

RODRIGUES, Maria A. C. S. A modinha em Vila Boa de Goiás. Goiânia, Editora UFG, 1982.

ROMERO, Silvio. Compêndio de história da literatura brasileira. Rio de Janeiro: Imago Ed., UFS, 2001[1906].

ROMERO, Silvio. Folclore brasileiro: cantos populares do Brasil. Belo Horizonte: Ed. Itatiaia; São Paulo: Edusp, 1985[1906].

ROMERO, Silvio. História da literatura brasileira. Rio de Janeiro: Imago Ed., UFS, 2001[1888].

ROSEN, C. El estilo clássico: Haydn, Mozart, Beethoven. Madrid: Alianza Editorial, 1986.

ROSEN, C. Formas de sonata. Barcelona: Editorial Labor, 1994.

RUGENDAS, Johann Moritz. Viagem pitoresca através do Brasil. Belo Horizonte: Itatiaia; São Paulo: Edusp, 1989.

RUSSELL-WOOD, A.J.R. Autoridades ambivalentes: e Estado do Brasil e a contribuição africana para a "boa ordem na República. In Maira Beatriz Nizza da Silva: Brasil: colonização e escravidão. Rio de Janeiro: Nova Fronteira, 2000.

SANDRONI, C. Feitiço decente: transformações do samba no Rio de Janeiro (1917-1933). Rio de Janeiro: Jorge Zahar Editor, 2001.

SANTOS, Afonso C. Marques dos. A invenção do Brasil: ensaios de história da cultura. Rio de Janeiro: Editora UFRJ, 2007.

SCHOENBERG, Arnold. Fundamentos da composição musical. São Paulo: Edusp, 1996.

SCHWARCZ, Lila M. O espetáculo das raças: cientistas, instituições e 
questão racial no Brasil, 18701930. São Paulo: Cia. das Letras, 1993.

SILVA, Ana Rosa Cloclet da. Inventando a nação: intelectuais ilustrados e estadistas luso-brasileiros na crise do Antigo Regime Português (1750-1822). São Paulo: Hucitec - Fapesp, 2006.

SILVA, Maria. B. N. da (org.). Colonização e escravidão. Rio de Janeiro: Nova Fronteira, 2000.

SIQUEIRA, Baptista. Modinhas do passado: cultura, folclore, música. Rio de Janeiro: Folha Carioca Editora Ltda, 1979[1957].

SOR, Fernando. Method for the Spanish Guitar. London: Tecla Editions, 1995.

SOUZA, André C. (Org.). Viola instrumental brasileira. Rio de Janeiro: Artviva, 2005.

SOUZA, Laura de M. História como desenho. In Revista de história da Biblioteca Nacional. Ano 4, n. 46, pp. 50-54, 2009.

SOUZA, Laura de M. (Org.). História da vida privada. São Paulo: Cia. das Letras, 1997.

SOUZA, Laura. de M. O diabo e a terra de Santa Cruz. São Paulo Cia. das Letras, 1986.

SOUZA, Laura de M. O sol e a sombra: política e administração na América portuguesa do século XVIII. São Paulo: Cia. das Letras, 2006.

SPIX, J. B. Viagem pelo Brasil: 1817-1821. Ed. Itatiaia; Ed. da Universidade de São Paulo, 1981. 3 vol.

STRAUMANN, Patrick (Org.). Rio de Janeiro, cidade mestiça: nascimento de uma nação. São Paulo: Cia. das Letras, 2001.

TELES, Gilberto M. Vanguarda européia e modernismo brasileiro. Petrópolis: Editora Vozes, 1972.

TELLO, Aurélio. Cancionero musical de Gaspar Fernandes. Cuba: Casa de las Américas. 1999.

TELLO, Aurélio. La danza em la época colonial Iberoamericana. Bolívia: APAC, 2006

TINHORÃO, José R. As festas no Brasil colonial. São Paulo: Ed. 34, 2000.

TINHORÃO, José R. Domingos Caladas Barbosa: o poeta da viola, da modinha e do lundu (1740-18000). São Paulo Ed. 34, 2004.

TINHORÃO, José R. História social da música popular brasileira. São Paulo: Ed. 34, 1998.

TINHORÃO, José R. Os negros em Portugal: uma presença silenciosa. São Paulo: Editora Caminho, 1997. 
TINHORÃO, José R. Os sons dos negros no Brasil - Cantos, danças, folguedos: origens. São Paulo: Ed. 34, 2008.

TINHORÃO, José R. Os sons dos negros no Brasil. 2. Ed. São Paulo: Ed. 34, 2008.

TINHORÃO, José R. Pequena história da música popular brasileira. 6ª . Ed.. São Paulo: Art Editora, 1991[1974].

TONAZZI, Bruno. Liuto, vihuela, chitarra e strumenti similari nelle loro intavolature: con cenni sulle loro letterature. Itália: Bèrben, 1974.

TRAVASSOS, Elizabeth. Modernismo e música brasileira. Rio de Janeiro: Jorge Zahar Editor, 2000.

TRAVASSOS, Elizabeth. Os mandarins milagrosos: arte e etnografia em Mário de Andrade e Béla Bartok. Rio de Janeiro: Jorge Zahar Editor, 1997.

TYLER, James \& SPARKS, Paul. The guitar and its music: from the Renaissnce to the Classical era. New York: Oxfor university press, 2002,

VATTIMO, Gianni. La fine della modernità. Italia: Garzanti Libri s.p.a., 1999.

VIEIRA DE CARVAHO, Mário. Pensar é morrer: ou o teatro de São Carlos na mudança do sistema sociocomunicativos desde fins do séc. XVIII aos nossos dias. Lisboa: Casa da Moeda, 1993.

VIEIRA DE CARVAHO, Mário. Razão e sentimento na comunicação musical. Lisboa: Antropos, 1999.

VOLPE, Maria Alice. Traços romerianos no mapa musical do Brasil. In: Ulhoa, Martha; Abreu, Martha; Velloso, Monica; Lopes, Antonio Herculano. (Org.). Música e História no Longo Século XIX. Rio de Janeiro: Casa de Rui Barbosa, 2010 (no prelo).

VOLPE. M. A. Remaking the Brazilian Myth of National Foundation: in Guarany. In Latin American Music Review / Revista de Música Latinoamericana, Vol. 23, No. 2, (Autumn - Winter, 2002), pp. 179-194: "the ideological discourse related to the myth of national foundation and the issue of inter-ethnic contact and miscegenation."

WALLERSTEIN, Immanuel. Impensar as ciências sociais: os limites dos paradigmas do Século XIX. São Paulo: Idéias \& Letras, 2006.

\section{2. Arquivos}

Biblioteca Nacional do Rio de Janeiro, acervo de música.

Biblioteca Nacional de Lisboa, acervo de manuscritos digitalizados.

Museu da Inconfidência, Ouro Preto (MG), arquivo Curt Lange. 


\subsection{Registros musicais (ordem cronológica)}

Modinhas fora de moda (1958)

Soprano: Lenita Bruno

Regência: Léo Peracchi

Selo: Festa - Irineu Garcia

Cantares Brasileiros 1 - A modinha - (1977)

Direção: Mozart de Araújo

Cia. Internacional de Seguros

Modinhas e Lundus - Bahia Musical (1984)

Manuel Veiga - BA

Viagem pelo Brasil - 2a ${ }^{\mathrm{a}}$. Edição (1990)

Ana Maria Kiefer - SP - AKRON

Marília de Dirceu - 2ª . Edição (1994)

Ana Maria Kiefer - SP

AKRON

Música de salão do tempo de D. Maria I (1993/4)

Segréis de Lisboa - Manuel Morais - Lisboa, PT

Moviplay

Modinhas e Lununs dos séculos XVIII e XIX (1997)

Segréis de Lisboa - Manuel Morais - Lisboa, PT

Moviplay

Modinhas Brasileiras - Songs from 19th Century Brazil (1997)

Andréa Daltro - Manuel Veiga - UK

Sarau das musas: canção brasileira nos salões (1830-1920) (1998)

Lea Vinocour, canto - Eduardo Villaça, Piano

Veneno de Agradar (1998)

Luiza Sawaia - Achille Picchi - Caxias/PT

21. 20 Modinhas - J. Manoel da Câmara / Sigismund Neukomm (1998)

Luiza Sawaia -Pedro Persone - SP/Br

Cancioneiro - 2000

Luiza Sawaia - Achille Picchi - Caixias/PT

Brasil 500 anos (2000)

Quadro Cervantes - RJ

Séc. XVI a XVIII 
Sempre Amor: Portuguese love songs from the romantic Age (2002)

Lorna Anderson, Soprano

Apollo chamber players - London - UK

Modinhas de Amor (2004)

Lira d'Orfeo - Edilson de Lima

Secretaria da Cultura- Guarulhos - SP

O amor Brazileiro - Modinhas e lundus do Brasil (2004)

Ensemble vocal e instrumental \& Vox Brasiliensis - Ricardo Kanji - SP

K617- França

Modinhas - Capella brasílica - Rodrigo Teodoro - MG (2005)

O ipê e você - trovas - 2005

Luiza Sawaia - Achille Picchi - Caixias/PT

Sementes do fado (2006)

Os músicos do Tejo - Portugal: Marcos Magalhães.

Brasil Imperial - Hino ao Sete de Abril: Modinhas e Lundus (2006)

Luiza Sawaia - Achille Picchi - Pedro Persone - Caixias/PT

Lundu de Marruá (2008)

Lira d'Orfeo - Edilson de Lima - Paulus - SP

Modinhas cariocas - A música na corte de d. João VI: Candido Ignácio da Silva, Gabriel F. da Trindade, J. Manoel da Câmara - Marcelo Fagerlande (2007/8)

\subsection{Coletâneas que contém Modinhas e Lundus}

Ninguém morra de ciúme - 1997

Colegium Musicum - MG

História da musica brasileira - Período Colonial II (s/d)

Vox Brasiliensis - Ricardo Kanji - SP

Klepsidra - Música profana no Brasil, séculos XVIII e XIX (2002)

Eduardo Klein - São Paulo 